
Ging W. Whan

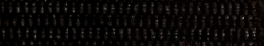
Whom 


\section{PBI39, 407}

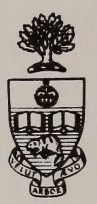

Presented to the

LIBRARY of the

UNIVERSITY OF TORONTO

by

Prof. F.P. Ide 
450

2 as - one

hacids Sealoqical map of L.S. - present in Enq. edn. of the sume yeu shi leefrntropice $\leftarrow$ UNII seepage 200

2.8de un ofr. 



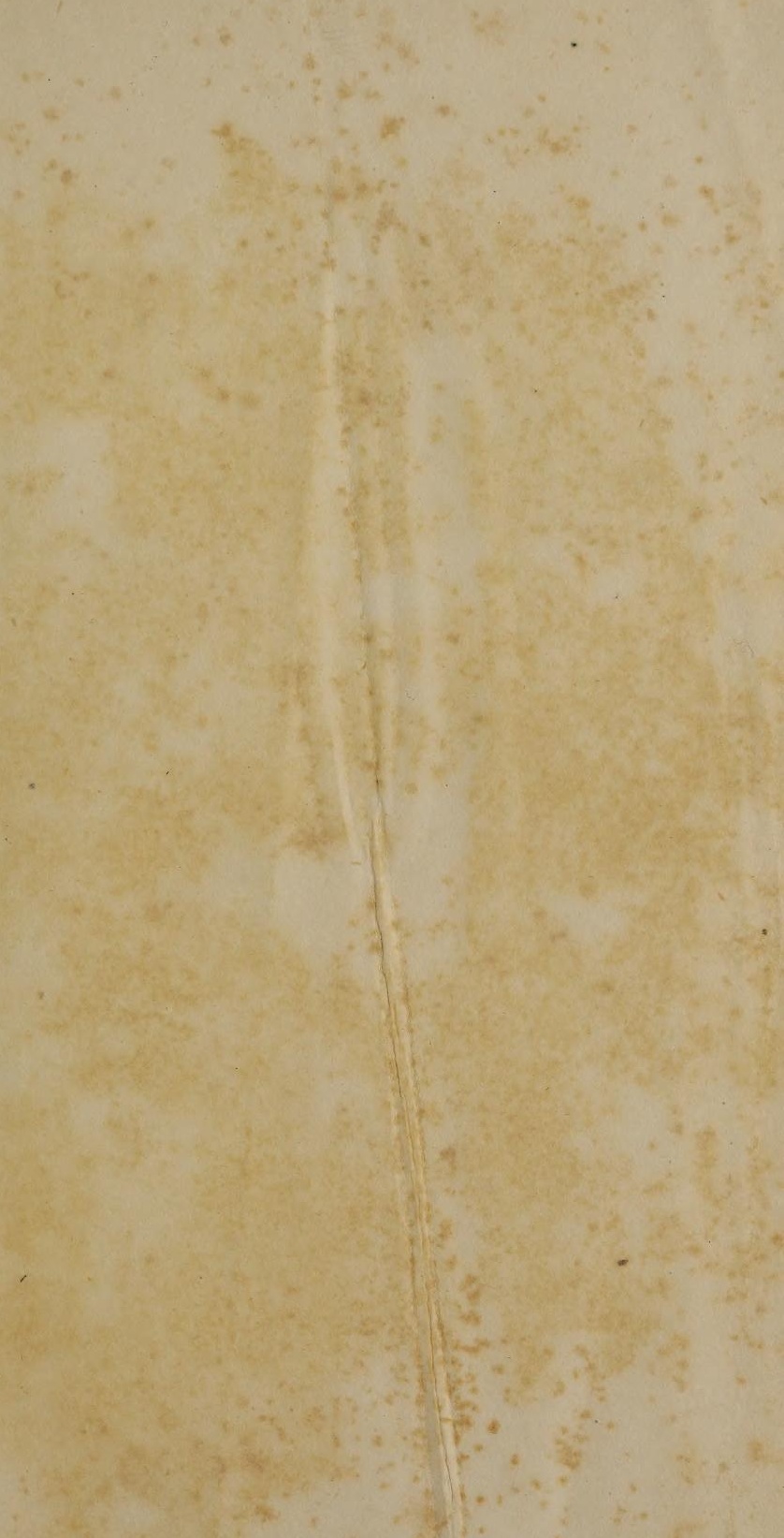



A.

s.

So

\section{axio}

$4=20, x^{4} x^{2}=$

3.

4in

iste

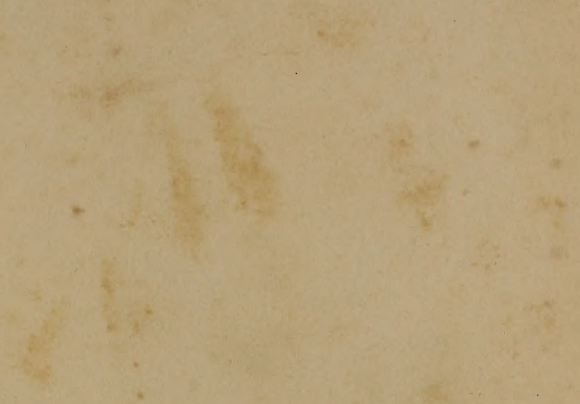

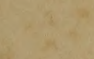

$x^{2}+1$

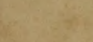

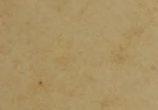

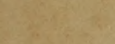

$\frac{2}{4}$

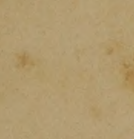

$x^{2}+y^{2}-14$ पis

$6 y^{2} 8$

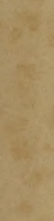

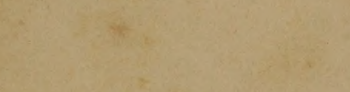

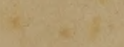

4.

1s 



\section{TRAVELS}

IN

\section{N 0 R T H A M E R I C A,}

IN THE YEARS 1841-2;

WITH

\section{GEOLOGICAL OBSERVATIONS}

ON

\section{T H E U N I T E D S T A T E S, CANADA, AND NOVA SCOTIA.}

\section{BY CHARLES LYELL, ESQ., F.R.S. AUTHOR OF THE PRINCIPLES OF GEOLOGY.

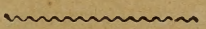

IN TWO VOLUMES. VOL. I.

NEW-YORK :

WILEY AND PUTNAM, 161 BROADWAY. 



\section{GEORGE TICKNOR, ESQ.,}

OF BOSTON, MASSACHUSETTS.

My deAR Mr. TiCKNor,

I am glad to have your permission to dedicate these volumes to you, in remembrance of the many happy days spent in your society, and in that of your family and literary friends at Boston; a remembrance which would be without alloy, were it not for my frequent regrets that the broad Atlantic should separate so many congenial souls whom we both of us number among our friends in Europe and America.

Believe me,

With feelings of great regard,

Ever faithfully yours,

Charles Lyell.

London, June 12, 1845. 



\section{PREFACE.}

ThE reader is reminded that the general map of the geology of the United States and Canada forms the frontispiece of the second volume, and that the line of my route is traced upon it in the manner described in the explanation of the map at Vol. II. p. 238

As the present work embraces a great variety of subjects to which my thoughts were turned during my travels in North America, I have endeavoured to confine myself as far as possible to the communication of such scientific matter as I thought might be of interest to the general reader. For a more detailed account of my geological observations alluded to in the course of these volumes, I must refer to the following published papers and abstracts of memoirs read to the Geological Society of London.

1. Letter to Dr. Fitton on the Blossberg Coal District and Stigmaria: Proceedings of the Geological Society, vol. iii. p. 554. 1841.

2. Recession of the Falls of Niagara: Ibid. vol. iii. p. 595 . 1842. Resumed, vol. iv. p. 19. 1843.

3. Tertiary Formations in Virginia and other parts of the United States : Ibid. vol. iii. p. 735. 1842.

4. Fossil Foot-Prints of Birds and Impressions of Rain-drops in Connecticut Valley. Ibid. vol. iii. p. 793. 1842.

5. Tertiary Strata of Martha's Vineyard in Massachusetts: Ibid. vol. iv. p. 31. 1843.

6. On the Geological Position of the Mastodon giganteus, and other Remains at Big Bone Lick, Kentucky, and other Localities in the United States. Ibid. vol. iv. p. 36. 1843. 
7. On upright Fossil Trees found in the Coal Strata of Cumberland, Nova Scotia: Silliman's Journal, vol. xlv. No. 2. p. 353. 1843.

8. Coal Formations, Gypsum, and Marine Limestones of Nova Scotia: Ibid. p. 356.

9. Bed of Plumbago and Anthracite in Mica-schist, near Worcester, Massachusetts, with Appendix containing Analyses by Dr. Percy: Quarterly Journ. of Geol. Soc. No. 2. p. 416. May, 1845.

10. Cretaceous Strata of New Jersey, with Appendix, on the Fossil Corals of the same, by Mr. Lonsdale: Ibid. No. 1. p. 301. Feb. 1845.

11. Miocene Formations of Virginia and North Carolina, \&c., with Appendix, on Fossil Corals, by Mr. Lonsdale : read to the Geol. Soc., March, 1845. Preparing for publication, Ibid. No. 4.

12. On the White Limestone of South Carolina and Georgia, and the Eocene Strata of other parts of the U. S., with Appendix, on the Corals, by Mr. Lonsdale : read to the Geol. Soc., March, 1845. Preparing for publication, Ibid. No. 4.

Abstracts of most of these papers have also appeared in Silliman's "American Journal of Science and Arts," for the corresponding years.

London, June 14th, 1845.

For the Description of the Plates and Maps, see Vol. II.p. 198. 


\section{CONTENTS OF VOLUME I.}

\section{CHAPTER I.}

\section{PAGE}

Voyage.-Harbour of Halifax.-Excursions near Boston.-Difference of Plants from European Species, and Correspondence of Marine Shells.-Resemblance of Drift, Erratics, and Furrowed Rocks, to those of Sweden.-Springfield.New Haven.-Scenery of the Hudson.-Albany.-Geological Surveys.-Mohawk Valley.-Ancient or Silurian Formations.-Prosperity and rapid Progress of the People.Lake Ontario.-Tortoises.-Fossil Remains of Mastodon.....

\section{CHAPTER II.}

Distant and near View of the Falls of Niagara.-Whether the Falls have receded from Queenston to their present Site-Geographical Features of the Region.-Course of the River above and below the Falls.-Recent Proofs of Erosion.-Historical Data in the Works of Hennepin and Kalm.-Geological Evidence derived from Fluviatile Strata or Remnants of an old River-bed in Goat-Island and elsewhere.-Difficulty of computing the Rate of the Retrograde Movement.-Varying Hardness and Thickness of the Rocks undermined.-Future Recession.-Age of the Drift and Limestone Escarpments.-Successive changes which preceded and accompanied the origin of the Falls.-Reflections on the Lapse of past Time............................

\section{CHAPTER III.}

Tour from the Niagara to the Northern Frontier of Pennsylvania.-Ancient Gypsiferous Formation of New York.Fossil Mastodon at Geneseo.-Scenery.-Sudden Growth of New Towns.-Coal of Blossberg, and resemblance to British 
Coal-Measures.-Stigmaria.-Humming Birds.-Nomenclature of Places.-Helderberg Mountains and Fossils.-Refractory Tenants.-Travelling in the States.-Politeness of Women.-Canal Boat.-Domestic Service.-Progress of Civilisation.-Philadelphia._Fire-engines.............

\section{CHAPTER IV.}

Excursion to New Jersey.-Cretaceous Rocks compared to European.-General Analogy of Fossils, and Distinctness of Species.-Tour to the Anthracite Region of the Alleghanies in Pennsylvania.-Long parallel Ridges and Valleys of these Mountains.-Pottsville.-Absence of Smoke.-Fossil Plants same as in Bituminous Coal.-Stigmariæ.-Great Thickness of Strata.-Origin of Anthracite.-Vast Area of the Appalachian Coal-Field.-Progressive Debituminization of coal from West to East.-General Remarks on the different Groups of Rocks between the Atlantic and the Mississippi.Law of Structure of the Appalachian chain discovered by the Professors Rogers.-Increased Folding and Dislocation of Strata on the South-eastern flank of the Appalachians.Theory of the Origin of this Mountain chain.............

\section{CHAPTER V.}

Wooded Ridges of the Alleghany Mountains.-German Patois in Pennsylvania.-Lehigh Summit Mine.-Effects of Ice during a Flood in the Delaware.-Election of a Governor at Trenton and at Philadelphia.-Journey to Boston.Autumnal Tints of the Foliage.-Boston the Seat of Commerce, of Government, and of a University.-Lectures at the Lowell Institute.-Influence of Oral Instruction in Literature and Science.-Fees of Public Lecturers.-Education Funds sunk in costly Buildings.-Advantages of anti-building clauses -Blind Asylum.-Lowell Factory.-National Schools.-Equality of Sects.-Society in Boston...........

\section{CHAPTER VI.}

Fall of Snow and Sleigh-driving at Boston.-Journey to New Haven.-Ichthyolites of Durham, Connecticut.-Age of Red Sandstone.-Income of Farmers.-Baltimore.-Washington.-National Museum.-Natural Impediments to the Growth of Washington.-Why chosen for the Capital.-Richmond, Virginia._Effects of Slave Labour.-Low Region 
on the Atlantic Border, occupied by Tertiary Strata.-In fusorial Bed at Richmond.-Miocene Shells and Corals in the Cliffs of the James River compared with Fossils of the European Crag and Faluns.-Analogy of Forms and Difference of Species.-Proportion of Species.-Commencement of the present Geographical Distribution of Mollusca.......

\section{CHAPTER VII.}

Pine Barrens of Virginia and North Carolina.-Railway Train stopped by Snow and Ice.-The great Dismal Swamp.Soil formed entirely of Vegetable Matter.-Rises higher than the contiguous firm Land.-Buried Timber.-Lake in the Middle.-The Origin of Coal illustrated by the Great Dismal.-Objections to the Theory of an ancient Atmosphere highly charged with Carbonic Acid..................

\section{CHAPTER VIII.}

Tour to Charleston, South Carolina.-Facilities of Locomotion.-Augusta.-Voyage down the Savannah River.-Shell Bluff.-Slave Labour.-Fever and Ague.-Millhaven.-Pine Forests of Georgia.-Alligators and Land Tortoises.-Warmth of Climate in January.-Tertiary Strata on the Savannah.Fossil Remains of Mastodon and Mylodon near Savannah.Passports required of Slaves.-Cheerfulness of the Negroes.

\section{CHAPTER IX.}

Return to Charleston.-Fossil Human Skeleton.-Geographical Distribution of Quadrupeds in North America.-Severe Frost in 1835 in South Carolina.-White Limestone of the Cooper River and Santee Canal.-Referred to the Eocene Period, not intermediate between Tertiary and Chklk.Lime-sinks.-Species of Shells common to Eocene Straia in America and Europe.-Causes of the increased Insalubrity of the Low Region of South Carolina-Condition of the Slave Population.-Cheerfulness of the Negroes, their Vanity.-State of Animal Existence-Invalidity of Marriages.-The coloured Population multiply faster than the Whites.-Effect of the Interference of Abolitionists.-Law against Education.-Gradual Emancipation equally desirable for the Whites and the Coloured Race.................. 
CHAPTER X.

Wilmington, North Carolina.-Mount Vernon.--Return to Philadelphia.-Reception of $\mathrm{Mr}$. Dickens.-Museum and Fossil Human Bones.-Penitentiary.-Churches.-Religious Excitement.-Coloured People of Fortune.-Obstacles to their obtaining Political and Social Equality. - No natural Antipathy between the Races.-Negro Reservations.......

CHAPTER XI.

Philadelphia_-Financial Crisis.-Payment of State Dividends suspended.-General Distress and Private Losses of the Americans.-Debt of Pennsylvania.-Public Works.-Direct Taxes.-Deficient Revenue.-Bad Faith and Confiscations.Irresponsible Executive.-Loan Refused by European Capitalists in 1842.-Good Faith of Congress during the War in 1S12-14.-Effects of Universal Suffrage.-Fraudulent Voting.-Aliens.-Solvency and Good Faith of the Majority of the States.-Confidence of American Capitalists.-Reform of the Electoral Body.-General Progress of Society, and Prospects of the Republic.........................

\section{CHAPTER XII.}

New York City.-Geology.-Distribution of Erratic Rocks in Long Island.-Residence in New York.-Effects on Society of increased Intercourse of distant States.-Separation of the Capital and Metropolis.-Climate.-Geology of the Taconic Mountains.-Stratum of Plumbago and Anthracite in the Mica Schist of Worcester - Theory of its Origin.-Lectures for the Working Classes.-Fossil Foot-Prints of Birds in Red Sandstone.-Mount Holyoke.-Visit to the Island of Martha's Vineyard._Fossil Walrus.-Indias.............

\section{CHAPTER XIII.}

Meeting of Association of American Geologists at Boston.Popular Libraries in New England.-Large Sale of Literary Works in the United States.-American Universities.Harvard College, near Boston.-English Universities.-Peculiarities of their System.-Historical Sketch of the Causes of the Peculiarities not of Medieval Origin.-Collegiate Corporations.-Their altered Relations to the English Universities after the Reformation.-Constitution given to Oxford by Leicester and Laud.-System of Public Teaching, 
how superseded by the Collegiate.-Effects of the Change.Oxford Examination Statute of 1800.-Its subsequent Modification and Results.-Rise of Private Tutors at Oxford and Cambridge.--Consequences of this Innovation.-Struggle at Oxford in 1839 to restore the Professional System.-Causes of its Rejection.-Tractarianism.-Supremacy of Ecclesiastics.-Youthful Examiners.-Cambridge, advocacy of the System followed there.-Influence of the English Academical Plan on the Cultivation of the Physical Sciences, and all Branches of Progressive Knowledge.-Remedies and Reforms................................ 208 



\section{J OUR N A L}

OF A

\section{TOUR IN NORTH AMERICA, \\ IN $1841--2$.}

\section{CHAPTER I.}

Voyage.-Harbour of Halifax._Excursions near Boston.-Difference of Plants from European Species, and Correspondence of Marine Shells.-Resemblance of Drift, Erratics, and furrowed Rocks, to those of Sweden.-Springfield.-New Haven.-Scenery of the Hudson.-Albany.-Geological Surveys.-Mohawk Valley.Ancient or Silurian Formations.-Prosperity and rapid Progress of the People.-Lake Ontario.-Tortoises.-Fossil Remains of Mastadon.

July 20, 1841.-Sailed from Liverpool for Boston, U. S., in the steam-ship Acadia, which held her course as straight as an arrow from Cape Clear in Ireland to Halifax in Nova Scotia, making between 220 and 280 miles per day.

After the monotony of a week spent on the open sea, we were amused when we came near the great banks which extend from the southern point of New. foundland, by the rapid passage of the steamer through alternate belts of stationary fog and clear spaces warmed and lighted up with bright sunshine. Looking at the dense fog from the intermediate sunny 
regions, we could hardly be persuaded that we were not beholding land, so distinct and well-defined was its outline, and such the varieties of light and shade, that some of our Canadian fellow-passengers compared it to the patches of cleared and uncleared country on the north shore of the St. Lawrence. These fogs are caused by the meeting, over the great banks, of the warm waters of the gulf stream flowing from the south, and colder currents, often charged with floating ice, from the north, by which very opposite states in the relative temperature of the sea and atmosphere are produced in spaces closely contiguous. In places where the sea is warmer than the air, fogs are generated.

When the eye has been accustomed for many days to the deep blue of the central Atlantic, the greener tint of the sea over the banks is refreshing. We were within 150 miles of the southern point of Newfoundland when we crossed these banks, over which the shallowest water is said to be about thirty-five fathoms deep. The bottom consists of fine sand, which must be often ploughed up by icebergs, for several of them were seen aground here by some of our passengers on the 31 st of July last. The captain tells us that the worst months for crossing the Atlantic to and from Halifax are February and March, and the most agreeable ones, July, August, and September. The nearer we approached the American coast, the more beautiful and brilliant were the sunsets. We sometimes compared the changing hues of the clouds and sky to the blue and red colours in a pigeon's neck.

July 31.-On the eleventh day of our voyage we sailed directly into the harbour of Halifax, which by its low hills of granite and slate, covered with birch and 
spruce fir, reminded me more of a Norwegian fiord, such as that of Christiania, than any other place I had seen. I landed here for six hours, with my wife, during which we had time to drive about the town, and see the museum, where I was shown a large fossil tree filled with sandstone, recently sent from strata containing coal in the interior. I resolved to examine these before returning to England, as they appeared, by the description given us, to afford the finest examples yet known in the world of petrified trees occurring in their natural or erect position.

Letters, which we had written on the voyage, being now committed to the post-office at Halifax, were taken up next day by the Caledonia steam-ship for England, and in less than a month from the time of our quitting London, our friends in remote parts of Great Britain (in Scotland and in Devonshire) were reading an account of the harbour of Halifax, of the Micmac Indians with their Esquimaux features, paddling about in canoes of birch bark, and other novelties seen on the shores of the New World. It required the aid of the recently established rallroads at home, as well as the Atlantic steam-packets, to render such rapid correspondence possible.

August 2.-A run of about thirty hours carried us to Boston, which we reached in twelve and a half days after leaving Liverpool. The heat here is intense, the harbour and city beautiful, the air clear and entirely free from smoke, so that the shipping may be seen far off, at the end of many of the streets. The Tremont Hotel merits its reputation as one of the best in the world. Recollecting the contrast of every thing French when I first crossed the straits of Dover, I am aston- 
ished, after having traversed the wide ocean, at the resemblance of every thing I see and hear to things familiar at home. It has so often happened to me in our own island, without travelling into those parts of Wales, Scotland, or Ireland, where they talk a perfectly distinct language, to encounter provincial dialects which it is difficult to comprehend, that I wonder at finding the people here so very English. If the metropolis of New England be a type of a large part of the United States, the industry of Sam Slick, and other writers, in collecting together so many diverting Americanisms and so much original slang, is truly great, or their inventive powers still greater.

I made excursions to the neighbourhood of Boston, through Roxbury, Cambridge, and other places, with a good botanist, to whom 1 had brought letters of introduction. Although this is not the best season for wild flowers, the entire distinctness of the trees, shrubs, and plants, from those on the other side of the Atlantic, affords a constant charm to the European traveller. We admired the drooping American elm, a picturesque tree; and saw several kinds of sumach, oaks with deeply indented leaves, dwarf birches, and several wild roses. Large commons without heaths reminded me of the singular fact that no species of heath is indigenous on the American continent. We missed also the small "crimson-tipped" daisy on the green lawns, and were told that they have been often cultivated with care, but are found to wither when exposed to the dry air and bright sun of this climate. When weeds so common with us cannot be reared here, we cease to wonder at the dissimilarity of the native flora of the New World, Ye: whenever the aboriginal forests are 
cleared, we see orchards, gardens, and arable lands, filled with the same fruit trees, the same grain and vegetables, as in Europe, so bountifully has Nature provided that the plants most useful to man should be capable, like himself, of becoming cosmopolites.

$A u g .5$.-Went by railway to deliver letters and pay some visits at Nahant, situated on a promontory of the coast, about ten miles N.E. of Boston, where I examined the rocks of hornblende and syenite, traversed by veins of greenstone and basalt which often intersect each other. The surface of the rocks, wherever the incumbent gravel or drift has been recently removed, is polished, furrowed, and striated, as in the north of Europe, especially in Sweden, or in Switzerland, near the great glaciers.

On the beach or bar of sand and shingle, which unites the peninsula with the main land, I collected many recent shells, and was immediately struck with the agreement of several of the most abundant species with our ordinary British littoral shells. Among them were Purpura lapillus, Turbo (Littorina) rudis, Mytilus edulis, Modiola papuana, Mya arenaria, besides others which were evidently geographical representatives of our common species; such as Nassa trivittata, allied to our N. reticulata, T'urbo palliatus Say, allied to, if not the same as, our common Turbo neritoides, \&c. I afterwards added largely to the list of corresponding species and forms, and Dr. Gould of Boston showed me his collection of the marine shells of Massachusetts and the adjoining ocean, and gave me a list of 70 out of 197 species which he regarded as identical with shells from Europe. After comparing these on my return, with the aid of several able con- 
chologists, I am convinced that the greater part of these identifications are correct; and, in the place of some considered as doubtful, thereare others not enumerated in Dr. Gould's catalogue, which may be substituted, so as to establish a result for which few geologists were prepared, viz. that one third, or about 35 per cent, of the marine shells of this part of America are the same as those on the opposite side of the Atlantic; a large part of the remainder consisting of geographical representatives, and a fraction only of the whole affording characteristic or peculiar forms. I shall have many opportunities of pointing out the geological bearing of this curious, and to me very unexpected, fact.

Several excavations made for railways in the neighbourhood of Boston, through mounds of stratified and unstratified gravel and sand, and also through rock, enabled me to recognise the exact resemblance of this part of New England to the less elevated regions of Norway and Sweden, where granitic rocks are strewed over irregularly with sand and blocks of stone, forming a gently undulating country with numerous ponds and small lakes. Indeed, had I not been constantly reminded that I was in America, by the distinctness of the plants, and the birds flying about in the woods, the geological phenomena would have led me to suppose myself in Scotland, or some other part of Northern Europe. These heaps of sand and pebbles are entirely devoid of shells or organic remains, and occasionally huge rounded blocks, brought from a great distance, rest upon them, or are buried in them. The heaps are mainly composed, however, of the materials of neighbouring rocks. At some points the superficial gravel has been pierced to the depth of 100 , and even more 
than 200 , feet, without the solid rock being reached; but more commonly the loose detritus is of moderate thickness, and, when removed, a polished surface of granite, gneiss, or mica schist, is exposed, exhibiting a smooth surface, with occasional scratches or straight parallel furrows. Here and there, rounded and flattened domes of smoothed rock, similar in shape to the "roches moutonnées" which border the Alpine glaciers, are observable. The day after I landed, an excavation recently made for the monument now erecting on Bunker's Hill, enabled me to recognise the likeness of this drift to that of Scandinavia, and every day since I have seen fresh proofs of the complete correspondence of these remote districts. Professor Hitchcock has shown that in New England the parallel grooves or furrows have a general direction nearly north and south, but usually ten or fifteen degrees to the west of north. I have already seen, at Nahant and elsewhere, some marked deviations from this rule, which, however, is correct in the main, and these markings have been found to prevail at all heights in New England, even in mountains more than 2000 feet high.

I have already observed several rounded boulders with one flat side scratched and furrowed, as if it had been held firmly in one position when frozen into ice, and rubbed against a hard rocky bottom.

There is here, as in Sweden, so great an extent of low country remote from any high mountains, that we cannot attribute the effects above described to true glaciers descending in the open air from the higher regions to the plains. If we adopt the glacial theory, we must suppose the country to have been submerged, and that the northern drift was brought here by large bodies of 
floating ice, which, by repeatedly running aground on the bottom of the sea for thousands of years, and forcing along the sand under their enormous weight, polished and furrowed the rocky bottom, and on the melting of the ice, let fall their burden of stones or erratic blocks, together with mud and pebbles.

When we recollect that Boston is situated in the latitude of Rome, or in that of the north of Spain, and that the northern drift and erratic blocks in Europe are first met with about the 50th degree of latitude, and then increase as we travel towards the pole; there seems ground for presuming, that the greater cold which now marks the climate of North America had begun to prevail long before the present distribution of land and sea in the northern hemisphere, and before the present climates were established. Perhaps, even in the glacial period of geology, the lines of equal winter's cold, when drawn from Europe to North America, made a curve of about $10^{\circ}$ to the southward, as in our own times.

Aug. 9.-After a week spent very agreeably at Boston, we started for New Haven in Connecticut, going the first hundred miles on an excellent railway in about five hours, for three dollars each. The speed of the railways in this State, the most populous in the Union, is greater than elsewhere, and I am told that they are made with American capital, and for the most part pay good interest. There are no tunnels, and so few embankments that they afford the traveller a good view of the country. The number of small lakes and ponds, such as are seen in the country between Lund and Stockholm, in Sweden, affords a pleasing variety to the scenery, and they are as useful 
as they are ornamental. The water is beautifully clear, and when frozen to the depth of many feet. in winter, supplies those large cubical masses of ice, which are sawed and transported to the principal cities throughout the Union, and even shipped to Calcutta, crossing the equator twice in their outward voyage. It has been truly said, that this part of New England owes its wealth to its industry, the soil being sterile, the timber small, and there being no staple commodities of native growth, except ice and granite.

In the inland country between Boston and Springfield, we saw some sand-hills like the dunes of blown sand near the coast, which were probably formed on the sea-side before the country was elevated to its present height. We passed many fields of maize, or Indian corn, before arriving at Springfield, which is a beautiful village, with fine avenues of the American elm on each side of the wide streets. From Springfield we descended the river Connecticut in a steamboat. Its banks were covered with an elegant species of golden rod (Solidago), with its showy bright yellow flowers. I have been hitherto disappointed in seeing no large timber, and I am told that it was cut down originally in New England without mercy, because it served as an ambush for the Indians, since which time it has never recovered, being consumed largely for fuel. The Americans of these Eastern States who visit Europe have, strange to say, derived their ideas of noble trees more from those of our principal English parks, than from the native forests of the New World.

I visited Rocky Hill, near Hartford in Connecticut, where the contact is seen of a large mass of columnar trap with red sandstone. In a large quarry, the dis- 
tinct joints which divide the sandstone contrast finely with the divisional planes which separate the basalt into pillars. The evidence of alteration by heat at the point of contact is very marked, and has been well described by Dr. Silliman in a paper on the rocks of this place.

The city of New Haven, with a population of 14,000 souls, possesses, like Springfield, fine avenues of trees in its streets, which mingle agreeably with the buildings of the university, and the numerous churches, of which we counted near twenty steeples. When attending service, according to the Presbyterian form, in the College chapel on Sunday, I could scarcely believe I was not in Scotland.

In an expedition to the north of the town, accompanied by Professor Silliman, his son, and Mr. Percival, a geologist to whom the execution of the State Survey of Connecticut was entrusted, I examined the red sandstone (New Red) and intrusive volcanic rocks (basalt and greenstone) of this neighbourhood. Dykes of various sizes intersect the stratified rocks, and occasionally flow in great tabular masses nearly parallel to the strata, so as to have the picturesque effect of cappings of columnar basalt, although Mr. Percival has shown that they are in reality intrusive, and alter the strata in contact both above and below. The East and West Rocks near New Haven, crowned with trap, bear a strong resemblance in their outline and general aspect to Salisbury Crags, and other hills of the same structure near Edinburgh.

We saw in Hampden parish, lat. $41^{\circ} 19^{\prime}$, on the summit of a high hill of sandstone, a huge erratic block of greenstone, 100 feet in circumference, and pro- 
jecting 11 feet above ground. Other large transported fragments have been met with more than 1000 feet above the level of the sea, and every where straight parallel furrows appear on the smooth surface of the rocks, where the superficial gravel and sand are removed.

In a garden at New Haven (August 13.) I saw, for the first time, a humming bird on the wing. It was fluttering round the flowers of a Gladiolus. In the suburbs we gathered a splendid wild flower, the scarlet Lobelia, and a large sweet-scented water-lily. The only singing bird which we heard was a thrush with a red breast, which they call here the robin. The grasshoppers were as numerous and as noisy as in Italy. As we returned in the evening over some low marshy ground, we saw several fire-flies, showing an occasional bright spark. They are small beetles resembling our male glow-worms (Lampyris Linn., Pyrolampis scintillans Say).

Aug. 13.-A large steamer carried us from New Haven to New York, a distance of about ninety miles, in less than six hours. We had Long Island on the one side, and the main land on the other, the scenery at first tame from the width of the channel, but very lively and striking when this became more contracted, and at length we seemed to sail into the very suburbs of the great city itself, passing between green islands, some of them covered with buildings and villas. We had the same bright sunshine which we have enjoyed ever since we landed, and an atmosphere unsullied by the chimnies of countless steam-boats, factories, and houses, of a population of more than 300,000 souls, 
thanks to the remoteness of all fuel save anthracite and wood.

Next day, I went with Mr. Redfield, well known by his meteorological writings, across the Passaic river to Newark in New Jersey, where we examined quarries of the New Red Sandstone, and saw the surfaces of the strata ripple-marked, and with impressions of raindrops. They also exhibit casts on their under sides of cracks, which have been formed by the shrinking of the layers of clay when drying. These appearances, together with imbedded fragments of carbonized fossil wood, such as may have been drifted on a beach, bespeak the littoral character of the formation on which, in many places in Connecticut and Massachusetts, the fossil footsteps of birds, to which I shall afterwards allude, have been found imprinted.

Aug. 16. - Sailed in the splendid new steam-ship the Troy, in company with about 500 passengers, from New York to Albany, 145 miles, at the rate of about 16 miles an hour. When I was informed that "seventeen of these vessels went to a mile," it seemed incredible, but I found that in fact the deck measured 300 feet in length. To give a sufficient supply of oxygen to the anthracite, the machinery is made to work two bellows, which blow a strong current of air into the furnace. The Hudson is an arm of the sea or estuary, about twelve fathoms deep, above New York, and its waters are inhabited by a curious mixture of marine and fresh-water plants and mollusca. At first on our left, or on the western bank, we had a lofty precipice of columnar basalt from 400 to 600 feet in height, called the Palisades, extremely picturesque. This basalt rests on sandstone, which is of the same age as 
that before mentioned near New Haven, but has an opposite or westward dip. On arriving at the Highlands, the winding channel is closed in by steep hills of gneiss on both sides, and the vessel often holds her course as if bearing directly on the land. The stranger cannot guess in which direction he is to penetrate the rocky gorge, but he soon emerges again into a broad valley, the blue Catskill mountains appearing in the distance. The scenery deserves all the praise which has been lavished upon it, and when the passage is made in nine hours it is full of variety and contrast.

At Albany, a town finely situated on the Hudson, and the capital of the State of New York, I found several geologists employed in the Government survey, and busily engaged in forming a fine museum, to illustrate the organic remains and mineral products of the country. This State is divided into about the same number of counties as England, and is not very inferior to it in extent of teritory. The legislature four years ago voted a considerable sum of money, more than 200,000 dollars, or 40,000 guineas, for exploring its Natural History and mineral structure; and at the end of the first two years several of the geological surveyors, of whom four principal ones were appointed, reported, among other results, their opinion, that no coal would ever be discovered in their respective districts. This announcement caused no small disappointment, especially as the neighbouring state of Pennsylvania was very rich in coal. Accordingly, during my tour, I heard frequent complaints that, not satisfied with their inability to find coal themselves, the surveyors had decided that no one else would ever be able to detect any, having had the presumption to pass a sentence of future 
sterility on the whole land. Yet, in spite of these expressions of ill-humour, it was satisfactory to observe that the rashness of private speculators had received a wholesome check; and large sums of money, which for twenty years previously had been annually squan. dered in trials for coal in rocks below the carboniferouss series, were henceforth saved to the public. There can be little doubt that the advantage derived to the re sources of the State by the cessation of this annual outlay alone, and the more profitable direction since given to private enterprise, is sufficient to indemnify the country, on mere utilitarian grounds, for the sum so munificently expended by the government on geological investigations. The resemblance of certain Silurian rocks on the banks of the Hudson river to the bituminous shales of the true Coal formation was the chief cause of the deception which misled the mining adventurers of New York. I made an excursion southwards from Albany, with a party of geologists, to Normanskill Creek, where there is a waterfall, to examine these black slates, containing graptolites, trilobites, and other Lower Silurian fossils. By persons ignorant of the order of superposition and of fossil remains, they might easily be mistaken for Coal measures, especially as some small particles of anthracite, perhaps of animal origin, do actually occur in them.

On leaving Albany, I determined so to plan my route to the Falls of Niagara and back again to the Hudson, as to enable me to see by the way the entire succession of mineral groups from the lowest Silurian up to the coal of Pennsylvania. Mr. James Hall, to whose hands the north-west division of the geological survey of New York had been confided, kindly offered himself as my 
guide. Taking the railway to Schenectady, and along the Mohawk valley, we first stopped at Little Falls, where we examined the gneiss and the lowest Silurian sandstone resting upon it. We then pursued our journey along the line of the Erie Canal and the Mohawk River, stopping here and there to examine quarries of limestone, and making a short detour through the beautiful valley of Cedarville in Herkimer County, where there is a fine section of the strata. Afterwards we explored the picturesque ravine through which the Genesee flows at Rochester, the river descending by a succession of cataracts over the same rocks which are exposed farther westward on the Niagara. The excavations also made for the grand canal at Lockport afforded us a fine opportunity of seeing these older fossiliferous rocks laid open to view. At this point the barges laden with merchandise climb up, by a series of locks placed one above the other, to the table land in which Lake Erie is situated. In the course of this short tour, I became convinced that we must turn to the New World if we wish to see in perfection the oldest monuments of the earth's history, so far at least as relates to its earliest inhabitants. Certainly in no other country are these ancient strata developed on a grander scale, or more plentifully charged with fossils; and, as they are nearly horizontal, the order of their relative position is always clear and unequivocal. They exhibit, moreover, in their range from the Hudson River to the Niagara, some fine examples of the gradual manner in which certain sets of strata thin out when followed for hundreds of miles, while others previously wanting become intercalated in the series. Thus, for example, some of the limestones which are several hundred feet 
thick in the Helderberg Hills, near Albany, are scarcely forty feet thick in the Niagara district; and on the other hand, the rocks over which the cataract of $\mathrm{Ni}$ agara is precipitated, dwindle away to such insignificant dimensions when followed eastward to the hills S. W. of Albany, that their place in the series there can scarcely be recognised. Another interesting fact may be noticed as the result even of a cursory survey of the fossils of these North American rocks, namely, that while some of the species agree, the majority of them are not identical with those found in strata, which are their equivalents in age and position on the other side of the Atlantic. Some fossils which are identical, such as Atrypa afinis, Leptcena depressa, and L. eugly$p h a$, are precisely those shells which have a great vertical and horizontal range in Europe, - -species which were capable of surviving many successive changes in the earth's surface, and for the same reason enjoyed at certain periods a wide geographical range. It has been usually affirmed that in the rocks older than the carboniferous, the fossil fauna in different parts of the globe was almost every where the same; but, judging from the first assemblage of organic remains which $I$ have seen here, it appears to me, that however close the general analogy of forms may be, there is evidence of the same law of variation in space as now prevails in the living creation.

A few years ago, it was a fatiguing tour of many weeks to reach the Falls of Niagara from Albany. We are now carried along at the rate of sixteen miles an hour, on a railway often supported on piles, through large swamps covered with aquatic trees and shrubs, or through dense forests, with occasional clearings where 
orchards are planted by anticipation among the stumps, before they have even had time to run up a $\log$-house. The traveller views with surprise, in the midst of so much unoccupied land, one flourishing town after another, such as Utica, Syracuse, and Auburn. At Rochester he admires the streets of large houses, inhabited by 20,000 souls, where the first settler built his log-cabin in the wilderness only twenty-five years ago. At one point our train stopped at a handsome new built station-house, and, looking out at one window, we saw a group of Indians of the Oneida tribe, lately the owners of the broad lands around, but now humbly offering for sale a few trinkets, such as baskets ornamented with porcupine quills, moccasins of moose-deer skin, and boxes of birch-bark. At the other window stood a welldressed waiter handing ices and confectionary. When we reflect that some single towns, of which the foundations were laid by persons still living, can already number a population, equal to all the aboriginal hunter tribes who possessed the forests for hundreds of miles around, we soon cease to repine at the extraordinary revolution, however much we may commiserate the unhappy fate of the disinherited race. They who are accustomed to connect the romance of their travels in Europe or Asia with historical recollections and the monuments of former glory, with the study of masterpieces in the fine arts, or with grand and magnificent scenery, will hardly believe the romantic sensations which may be inspired by the aspect of this region, where very few points of picturesque beauty meet the eye, and where the aboriginal forest has lost its charm of savage wildness by the intrusion of railways and canals. The foreign naturalist indeed sees novelty in 
every plant, bird, and insect; and the remarkable resemblances of the rocks at so great a distance from home are to him a source of wonder and instruction. But there are other objects of intense interest, to enliven or excite the imagination of every traveller. Here, instead of dwelling on the past, and on the signs of pomp and grandeur which have vanished, the mind is filled with images of coming power and splendour. The vast stride made by one generation in a brief moment of time, naturally disposes us to magnify and exaggerate the rapid rate of future improvement. The contemplation of so much prosperity, such entire absence of want and poverty, so many school-houses and churches, rising every where in the woods, and such a general desire of education, with the consciousness that a great continent lies beyond, which has still to be appropriated, fills the traveller with cheering thoughts and sanguine hopes. He may be reminded that there is another side to the picture, that where the success has been so brilliant and where large fortunes have been hastily realised, there will be rash speculations and bitter disappointments ; but these ideas do not force themselves into the reveries of the passing stranger. $\mathrm{He}$ sees around him the solid fruits of victory, and forgets that many a soldier in the foremost ranks has fallen in the breach; and cold indeed would be his temperament if he did not sympathise with the freshness and hopefulness of a new country, and feel as men past the prime of life are accustomed to feel when in company with the young, who are full of health and buoyant spirits, of faith and confidence in the future.

Aug. 24.-In the suburbs of Rochester, Mr. Hall and I visited a spot where the remains of the great 
Mastodon had been dug up from a bed of white shellmarl. I found fragments of the fossil teeth and ivory of one tusk, and ascertained that the accompanying shells were of recent species of the genera Limnea, Planorbis, Valvata, Cyclas, \&c. We also examined the narrow ridge composed of sand and gravel between Rochester and Lake Ontario, which has been traced for a hundred miles, running nearly parallel to the lake, and from three to eight miles distant from it. It rises from ten to twenty feet above the general level of the surrounding plain of clay, and presents a steep slope to the north and south, affording an excellent road, like the sand-ridges or osars which I have seen in Sweden, and which are doubtless of similar origin. Geologists are all agreed that these and other similar ridges surrounding the great Canadian lakes, and occurring at different heights above them, were once lines of beach surrounding great bodies of water. Whether these consisted of lakes or seas,- - how the water came to stand at so many different levels, and whether some of the ridges were not originally banks and bars of sand formed under water, are points which I shall discuss in the sequel.

While we were roaming along the shore of Lake Ontario, to compare the old ridge road with the modern beach, we saw several tortoises of different species basking in the sun on logs of drift wood in the shallow ponds connected with the lake. We caught one of these (Testudo picta), which has a gaily coloured shell, and I afterwards carried it a day's journey in the carriage, and then turned it out, to see whether, as I was told, it would know its way back to Lake Ontario. I am bound to admit that its instinct on this 
occasion did not fail, for it made directly for a ravine, in the bottom of which was a stream that would lead it in time to the Genesee River, and this would carry it to its native lake, if it escaped destruction at the falls below Rochester, where the celebrated diver, Sam Patch, perished, after he had succeeded in throwing himself with impunity down several other great waterfalls. There is a fresh-water tortoise in Europe (Terrapena Europea), found in Hungary, Prussia, and Silesia, as far north as lat. $50^{\circ}$ to $52^{\circ}$. It also occurs near Bordeaux, and in the north of Italy, $44^{\circ}$ and $45^{\circ}$ $\mathrm{N}$. lat., which precisely corresponds with the latitude of Lake Ontario.

In moist places along the lake shore, and in the lanes and high roads, we saw numerous yellow butterflies (Colias philodice-C. Europorna of some authors) very like a British species. Sometimes forty clustering on a small spot resembled a plot of primroses, and as they rose altogether, and flew off slowly on every side, it was like the play of a beautiful fountain.

On our way home through the woods we stopped at the cabin of some new settlers near the lake, many miles from any neighbours, in the midst of a square clearing covered with blackened stumps, where not a single tree or shrub had been spared. The view was bounded on every side by a dense wall of dark wood striped with white by the vertical lines of the numerous tall and straight trees without side branches, and supporting a dark canopy of foliage. When we admired the forest, the settler's wife was pleased, but said, sighing, that she could not get her children to see any beauty in trees. They had never known the old 
Chap. I.

country, nor other friends, and were happier than she and her husband could be, though in their worldly concerns they were thriving, and had every reason to feel content, except when attacked by the ague, so common in the newly-cleared grounds. 


\section{CHAPTER II.}

Distant and near View of the Falls of Niagara.-Whether the Falls have receded from Queenston to their present Site.-Geographical Features of the Region.-Course of the River above and below the Falls.-Recent Proofs of Erosion.-Historical Duta in the Works of Hennepin and Kalm.-Geological Evidence derived from Fluviatile Strata or Remnants of an old River-hed in Goat Island and elsewhere.-Difficulty of computing the Rate of the retrograde Movement.-Varying Hardness and Thickness of the Rocks undermined.-Future Recession.-Age of the Drift and Limestone Escarpments.-Successive Changes which preceded and accompanied the Origin of the Falls.-Reflections on the Lapse of past Time.

Aug. 27.-We first came in sight of the Falls of Niagara when they were about three miles distant. The sun was shining full upon them-no building in view-nothing but the green wood, the falling water, and the white foam. At that moment they appeared to me more beautiful than I had expected, and less grand; but after several days, when I had enjoyed a nearer view of the two cataracts, had listened to their thundering sound, and gazed on them for hours from above and below, and had watched the river foaming over the rapids, then plunging headlong into the dark pool,--and when I had explored the delightful island which divides the falls, where the solitude of the ancient forest is still unbroken, I at last learned by degrees to comprehend the wonders of the scene, and to feel its full magnificence.

Early in the morning after our arrival, I saw from the window of our hotel, on the American side, a long train of white vapoury clouds hanging over the deep 
chasm below the falls. They were slightly tinted by the rays of the rising sun, and blown slowly northwards by a gentle breeze from the pool below the cataract, which was itself invisible from this point of view. No fog was rising from the ground, the sky was clear above; and as the day advanced, and the air grew warm, the vapours all disappeared. This scene reminded me of my first view of Mount Etna from Catania, at sunrise in the autumn of 1828 , when I saw dense volumes of steam issuing from the summit of the highest crater in a clear blue sky, which, at the height of more than two miles above the sea, assumed at once the usual shape and hues of clouds in the upper atmosphere. These, too, vanished before noon, as soon as the sun's heat increased.

Etna presents us not merely with an image of the power of subterranean heat, but a record also of the vast period of time during which that power has been exerted. A majestic mountain has been produced by volcanic action, yet the time of which the volcano forms the register, however vast, is found by the geologist to be of inconsiderable amount, even in the modern annals of the earth's history. In like manner, the Falls of Niagara teach us not merely to appreciate the power of moving water, but furnish us at the same time with data for estimating the enormous lapse of ages during which that force has operated. A deep and long ravine has been excavated, and the river has required ages to accomplish the task, yet the same region affords evidence that the sum of these ages is as nothing, and as the work of yesterday, when compared to the antecedent periods, of which there are monuments in the same district. 
It has long been a favourite subject of discussion whether the Falls were once situated seven miles farther north, or at Queenston. The ideal bird's-eye view given in the frontispiece may assist the reader who has not visited the spot to form a tolerably correct general notion of the geographical configuration of this country, which is very simple. The view has been constructed from a sketch published by Mr. Bakewell, in Loudon's Magazine for 1830, into which the geological representation of the rocks, as they appear on the surface and in the ravine of the Niagara, has been introduced from the State Survey by Mr. Hall.* The platform, in a depression of which Lake Erie is situated, is more than 330 feet above Lake Ontario, and the descent from a higher to a lower level is sudden and abrupt at the escarpment called the Queenston heights. The strata throughout this whole region are nearly horizontal, but they have a gentle dip to the south of 25 feet in a mile. This inclination is sufficient to cause the different groups of rock to crop out one from beneath the other, or come up to the surface in parallel zones, which may be traced for a great distance east and west through the state of New York and Canada. (See Map.) They all consist of different members of the Silurian series, the uppermost or newest being those nearest to Lake Erie. (See section fig. 4., p. 37.) In the bird's-eye view, the Niagara is seen bounded by

* Mr. Bakewell gave me his original sketches in 1841, and I conceived the idea of combining his pictorial view with a geological representation of the rocks before I gave a lecture on the Niagara district at Boston, in October, 1841, in which, and in planning some of the other diagrams, and in discussing the theory of recession, $I$ was assisted by Mr. Hall. 

low banks where it issues from Lake Erie, and varying in width from one to three miles. It here resembles a prolongation of the tranquil lake, being interspersed with low wooded islands. This lake-like scenery continues for about fifteen miles, during which the fall of the river scarcely exceeds as many feet, but on reaching the rapids, it descends over a limestone bed about 50 feet in less than a mile, and is then thrown down about 165 feet perpendicularly at the Falls. The largest of these, called the Horseshoe Fall, is $\mathbf{1 8 0 0}$ feet, or more than a third of a mile, broad, the island in the midst somewhat less in width, and the American Fall about 600 feet swide. The deep narrow chasm below the great cataract is from 200 to 400 yards wide, and 300 feet deep; and here in seven miles the river descends 100 feet, at the end of which it emerges from the gorge into the open and flat country, so nearly on a level with Lake Ontario that there is only a fall of about four feet in the seven additional miles which intervene between Queenston and the Lake. The great ravine is winding, and makes a turn nearly at right angles to itself at the whirlpool, where the Niagara sweeps round a large circular basin, but it is represented in the frontispiece as nearly straight, for the sake of showing the stratification; and its proportional height is purposely exaggerated. At some points the boundary cliffs are undermined on one side by the impetuous stream, but there is usually a talus at the base of the precipice, supporting a very ornamental fringe of trees.

It has long been the popular belief, from a mere cursory inspection of this district, that the Niagara once flowed in a shallow valley across the whole platform from the present site of the Falls to the Queenston 
heights, where it is supposed the cataract was first situated, and that the river has been slowly eating its way backwards through the rocks for a distance of seven miles. According to this hypothesis, the Falls must have had originally nearly twice their present height, and must have been always diminishing in grandeur from age to age, as they will continue to do in future so long as the retrograde movement is prolonged. It becomes, therefore, a matter of no small curiosity and interest to inquire at what rate the work of excavation is now going on, and thus to obtain a measure for calculating how many thousands of years or centuries have been required to hollow out the chasm already excavated.

It is an ascertained fact, that the Falls do not remain absolutely stationary at the same point of space, and that they have shifted their position slightly during the last half century. Every observer will also be convinced that the small portion of the great ravine, which has been eroded within the memory of man, is so precisely identical in character with the whole gorge for seven miles below, that the river supplies an adequate cause for executing the task assigned to it, provided we grant sufficient time for its completion.

The waters, after cutting through strata of limestone, about fifty feet thick in the rapids, descend perpendicularly at the Falls over another mass of limestone about ninety feet thick, beneath which lie soft shales of equal thickness, continually undermined by the action of the spray driven violently by gusts of wind against the base of the precipice. In consequence of this disintegration, portions of the incumbent rock are left unsupported, and tumble down from time to time, 
so that the cataract is made to recede southwards. The sudden descent of huge rocky fragments of the undermined limestone at the Horseshoe Fall, in 1828, and another at the American Fall, in 1818, are said to have shaken the adjacent country like an earthquake. According to the statement of our guide in 1841, Samuel Hooker, an indentation of about forty feet has been produced in the middle of the ledge of limestone at the lesser fall since the year 1815, so that it has begun to assume the shape of a crescent, while within the same period the Horseshoe Fall has been altered so as less to deserve its name. Goat Island has lost several acres in area in the last four years, and I have no doubt that this waste neither is, nor has been, a mere temporary accident, since I found that the same recession was in progress in various other waterfalls which I visited with Mr. Hall, in the state of New York. Some of these intersect the same rocks as the Niagara-for example, the Genesee at Rochester; others are cutting their way through newer formations, as Allan's Creek below Le Roy, or the Genesee at its upper falls at Portage. Mr. Bakewell calculated that, in the forty years preceding 1830, the Niagara had been going back at the rate of about a yard annually, but I conceive that one foot per year would be a much more probable conjecture, in which case 35,000 years would have been required for the retreat of the Falls from the escarpment of Queenston to their present site, if we could assume that the retrograde movement had been uniform throughout. This, however, could not have been the case, as at every step in the process of excavation the height of the precipice, the hardness of the materials at its base, and the quantity of fallen matter to be re- 
Chap. II.

Seventy-three years afterwards, or in 1751 , a letter was published in the Gentleman's Magazine for that year by Kalm, the Swedish botanist, on the Falls of Niagara. His description is also illustrated by a plate, in which the proportional height and breadth of the Falls are given more correctly. The lesser Fall on the left bank of the river is omitted; but at the place where it had been represented in Father Hennepin's sketch, Kalm inserts the letter " $a$," referring to a note in which he says, "Here the water was formerly forced out of its direct course by a projecting rock, which when standing turned the water off obliquely across the other Fall."

This observation confirms the reality of Hennepin's oblique cascade, and shows that some waste had been going on in the intermediate seventy-three years, making a visible alteration in the scene, and leading us to infer that the rocks have been suffering continual dilapidation for more than the last century and a half.

In the absence of more ample historical data, we are fortunately not without geological evidence of the former existence of a channel of the Niagara at a much higher level, before the table-land was intersected by the great ravine. Long before my,visit to the Niagara, I had been informed of the existence on Goat Island of beds of gravel and sand containing fluviatile shells, and some account had been given of these by Mr. Hall in his first report in 1839 ; I therefore proposed to him that we should examine these carefully, and see if we could trace any remnants of the same along the edges of the river-cliffs below the Falls. We began by collecting in Goat Island shells of the genera Unio, Cyclas, Melania, Valvata, Limnea, Planorbis, and 
Helix, all of recent species, in the superficial deposit. They form regular beds, and numerous individuals of the Unio and Cyclas have both their valves united. We then found the same, formation exactly opposite to Fig. 1.

East.

West.

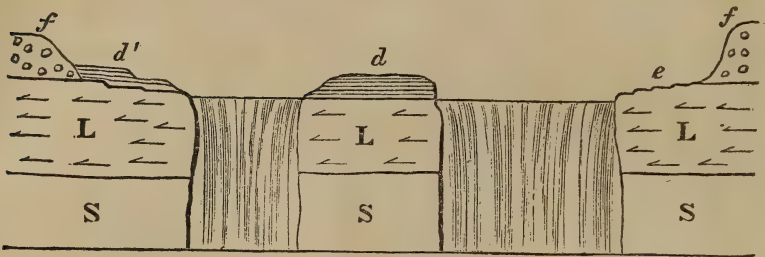

Section at Niagara Falls.

L. Limestone 80 feet thick. S. Shale 80 feet thick.

$d$. Freshwater strata on Goat Island, above 20 feet thick.

$d^{\prime}$. Same formation on the American side, containing bones of Mastodon.

$e$. Ledge of bare limestone on the Canada side.

$f$. Ancient drift.

the Falls on the top of the cliff (at $d^{\prime}$, fig. 1.) on the American side, where two river-terraces, one twelve and the other twenty-four feet above the Niagara, have been cut in the modern deposits. In these we observed the same fossil shells as in Goat Island, and learnt that the teeth and other remains of a mastodon, some of which were shown us, had been found thirteen feet below the surface of the soil. We were then taken by our guide to a spot farther north, where similar gravel and sand with fluviatile shells occurred near the edge of the cliff overhanging the ravine, resting on the solid limestone. It was about half a mile below the principal Fall, and extended at some points 300 yards inland, but no farther, for it was then bounded by the bank of more ancient drift ( $f$, fig. 1.). This deposit precisely occupies the place which the ancient bed and alluvial plain of the Niagara would naturally have filled, 
if the river once extended farther northwards, at a level sufficiently high to cover the greater part of Goat Island. At that period the ravine could not have existed, and there must have been a barrier, several miles lower down, at or near the whirlpool.

Fig. 2.

North.

South.

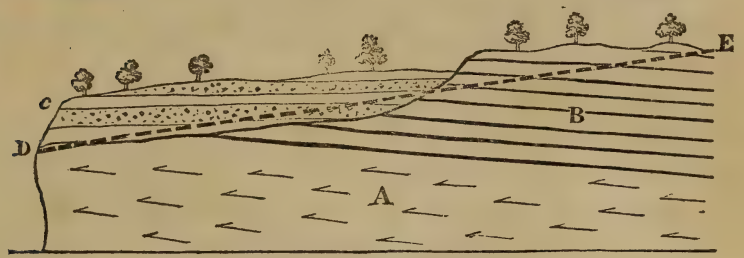

Section of Goat Island from North to South, 2500 feet in length.

A. Massive compact portion of the Niagara limestone.

B. Upper thin-bedded portion of the Niagara limestone, strata slightly inclined to the South.

c. Horizontal freshwater beds of gravel, sand, and loam, with shells.

$\mathrm{D}, \mathrm{E}$. Present surface of the river Niagara at the Rapids.

The supposed original channel, through which the waters flowed from Lake Erie to Queenston or Lewiston, was excavated chiefly, but not entirely, in the superficial drift, and the old river-banks eut in this drift are still to be seen facing each other, on both sides of the ravine, for many miles below the Falls. A section of Goat Island from south to north, or parallel to the course of the Niagara (see fig. 2.), shows that the limestone (B) had been greatly denuded before the fiuviatile beds $(c)$ were accumulated, and consequently when the Falls were still several miles below their present site. From this fact I infer that the slope of the river at the rapids was principally due to the original shape of the old channel, and not, as some have conjectured, to modern erosions on the approach of the Falls to the spot. 
The observations made in 1841 induced me in the following year (June, 1842) to re-examine diligently both sides of the river from the Falls to Lewiston and Queenston, to ascertain if any other patches of the ancient river-bed had escaped destruction. Accordingly, following first the edge of the cliffs on the eastern bank, I discovered, with no small delight, at the summer-house ( $\mathrm{E}$, fig. 3.), above the whirlpool, a bed of

Fig. 3.

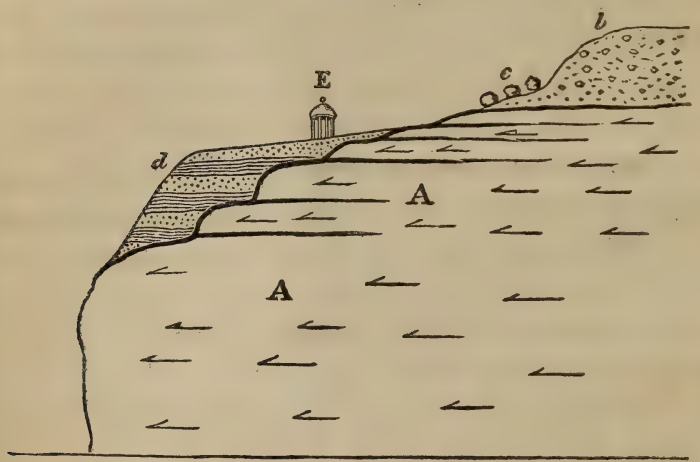

Section at the Summer-house above Whirlpool, east bank of Niagara.

A. Thick-bedded limestone, same as at Falls.

b. Ancient drift.

c. Boulders at base of steep bank formed by drift.

d. Freshwater strata forty feet thick.

E. Summer-house.

stratified sand and gravel, forty feet thick, containing fluviatile shells in abundance. Fortunately, a few yards from the summer-house a pit had been recently dug for the cellar of a new house to the depth of nine feet in the shelly sand, in which I found shells of the genera Unio, Cyclas, Melania, Helix, and Pupa, not only identical in species with those which occur in a fresh state in the bed of the Niagara, near the ferry, 
but corresponding also in the proportionate number of individuals belonging to each species, the valves of Cyclas similis, for example, being the most numerous. The same year I found also a remnant of the old riverbed on the opposite or Canadian side of the river, about a mile and a half above the whirlpool, or two miles and a half below the Falls. These facts appear conclusive as to the former extension of a more elevated valley, four miles, at least, below the Falls; and at this point the old river-bed must have been so high as to be capable of holding back the waters which covered all the patches of fluviatile sand and gravel, including that of Goat Island. As the table-land or limestone-platform rises gently to the north, and is highest near Queenston, there is no reason to suppose that there was a greater fall in the Niagara when it flowed at its higher level, than now between Lake Erie and the Falls; and according to this view, the old channel might well have furnished the required barrier.

I have stated that on the left, or Canadian bank of the Niagara, below the Falls, I succeeded in detecting sand with freshwater shells at one point only, near the mouth of the muddy river. The ledge of limestone on this side is usually laid bare, or only covered by vegetable mould (as at $e$, fig. 1.), until we arrive at the boulder clay ( $f$, fig. 1.), which is sometimes within a few yards of the top of the precipice, and sometimes again retires eighty yards or more from it, being from twenty to fifty feet in height. I also found an old river-bed running through the drift parallel to the $\mathrm{Ni}$ agara, its course still marked by swamps and ponds, such as we find in all alluvial plains, and only remarkable here because the river now runs at a lower level by 300 
feet. This deserted channel occurs between the Muddy River and the Whirlpool, and is 100 yards broad.

There is also a notch or indentation, called the "Devil's Hole," on the right or eastern side of the Niagara, half a mile below the Whirlpool, which deserves notice, for there, I think, there are signs of the Great Cataract having been once situated. A small streamlet, called the "Bloody Run," from a battle fought there with the Indians, joins the Niagara at this place, and has hollowed out a lateral chasm. Ascending the great ravine, we here see, facing us, a projecting cliff of limestone, which stands out forty feet beyond the general range of the river cliff below, and has its flat summit bare and without soil, just as if it had once formed the eastern side of the Great Fall.

By exploring the banks of the Niagara above the Falls, I satisfied myself that if the river should continue to cut back the ravine still farther southwards, it would leave here and there, near the verge of the precipice and on its islands, strata of sand and loam, with freshwater shells similar to those already described. I collected fossil shells, for example, on the left bank, near the Chippewa River, and learnt that others had been reached, in sinking a well, in 1818, at the south-east end of Grand Island. The situation of such deposits is represented at $a, a$ (fig. $\overline{4} .$, p. 37.).

The patches of fluviatile strata, therefore, occurring between the old banks of drift $(f, f$, fig. 1., p. 30.) and the precipice, and not having been met with on other parts of the platform at a distance from the Niagara, confirm the theory, previously adopted on independent evidence, of the recession of the Falls from Queenston southwards. The narrowness of the gorge near Queens- 
ton, where it is just large enough to contain the rapid current of water, accords well with the same hypothesis, and there is no ground for suspecting that the excavation was assisted by an original rent in the rocks, because there is no fissure at present in the limestone at the Falls, where the moving waters alone have power to cut their way backwards.

I have already remarked that there will always be insuperable difficulties in the way of estimating with precision the rate of the retrogression of the Falls in former ages, because at every step new strata have been successively exposed at the base of the precipice. According to their softer or harder nature, the undermining process must have been accelerated or retarded. This will be understood by reference to the annexed section (fig. 4.), where the line $b, c, d$, represents the present surface of the river along which the Falls have receded. The strata $(1,3$, and $\mathbf{7}$, ) are of soft materials; the others, $(2,4$, and 8$)$, which slightly project at their termination in the escarpment, are of a more compact and refractory kind. It has been necessary to exaggerate the southward dip of the strata in this diagram, which is in reality so slight as to be insensible to the eye, being only, as before mentioned, about twenty-five feet in a mile, the river channel sloping in an opposite direction at the rate of fifteen feet in a mile. These two inclinations, taken together, have caused, as Mr. Hall has pointed out in his Survey, a diminution of forty feet in the perpendicular height of the Falls for every mile that they receded southward. By reference to the section, the reader will perceive that when they were situated at the Whirlpool $(c)$, the quartzose sandstone (2), which is extremely hard, was at the base of 


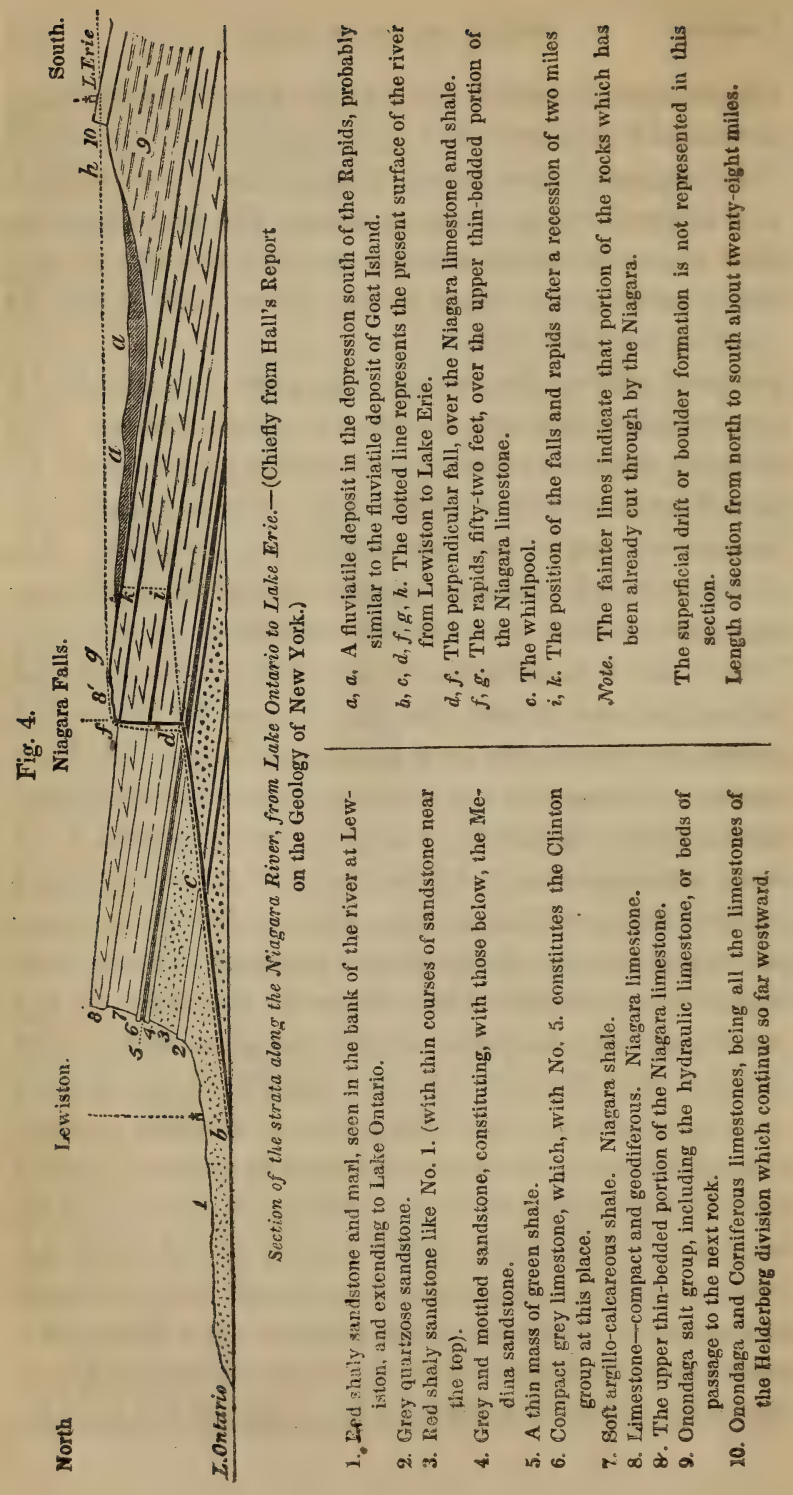


the precipice, and here the Great Cataract may have remained nearly stationary for ages.

In regard to the future retrocession of the Falls, it will be perceived by the same section (fig. 4.), that when they have travelled back two miles, or to $i, k$, the massive limestone (8), now at the top of the Falls, will then be at their base; and its great hardness may, perhaps, effectually stop the excavating process, if it should not have been previously arrested by the descent of large masses of the same rock from the cliff above. It will also appear that the Falls will continually diminish in height, and should they ever reach Lake Erie, they will intersect entirely different strata from those over which they are now thrown.

The next inquiry into which we are naturally led by our retrospect into the past history of this region, relates to the origin of the Falls. If they were once seven miles northward of their present site, in what manner, and at what geological period, did they first come into existence? In tracing back the series of past events, we have already seen that the last change was the erosion of the great ravine; previously to which occurred the deposition of the freshwater deposit, including fossil shells of recent species, and the bones of the Mastodon. Thirdly, of still older date was the drift or boulder formation which overspreads the whole platform and the face of the escarpment near Queenston, as well as the low country between it and Lake Ontario. Fourthly, the denudation of the line of cliff or escarpment, in which the table-land ends abruptly, preceded the origin of the drift. I shall endeavour to show, in a subsequent chapter, when speaking of Canada, that this drift was of marine origin, and formed when the 
whole country was submerged beneath the sea. In the region of the Niagara it is stratified, and though no fossils have as yet been detected in it, similar deposits occur in the valley of the St. Lawrence at Montreal, at a height nearly equal to Lake Erie, where fossil shells, of species such as now inhabit the northern seas, lie buried in the drift.

It is almost superfiuous to affirm that a consideration of the geology of the whole basin of the St. Lawrence and the great lakes can alone entitle us to speculate on the state of things which immediately preceded or accompanied the origin of the Great Cataract. To give even a brief sketch of the various phenomena to which our attention must be directed, in order to solve this curious problem, would require a digression of several chapters. At present the shortest and most intelligible way of explaining the results of my observations and reflections on this subject will be to describe the successive changes in the order in which I imagine them to have happened. The first event then to which we must recur is the superficial waste or denudation of the older stratified rocks (from 1 to 10 inclusive, section, fig. 4., p. 37.), all of which had remained nearly undisturbed and horizontal from the era of their formation beneath the sea to a comparatively modern period. That they were all of marine origin is proved by their imbedded corals and shells. They at length emerged slowly, and portions of their edges were removed by the action of the waves and currents, by which cliffs were formed at successive heights, especially where hard limestones (such as Nos. 10 and 8, fig. 4.) at Blackrock and Lewiston, were incumbent on soft shales. After this denudation the whole region was again gradually 
submerged, and this event took place during the glacial period, at which time the surfaces of the rocks already denuded were smoothed, polished, and furrowed by glacial action, which operated successively at different levels. The country was then buried under a load of stratified and unstratified sand, gravel, and erratic blocks, occasionally 80 , and in some hollows more than 300, feet deep. An old ravine terminating at St. David's, which intersects the limestone platform of the Niagara, and opens into the great escarpment, illustrates the posteriority of this drift to the epoch when the older rocks were denuded. The period of submergence last alluded to was very modern, for the shells then inhabiting the ocean belonged, almost without exception, to species still living in high northern, and some of them in temperate, latitudes. The next great change was the re-emergence of this country, consisting of the ancient denuded rocks, covered indiscriminately with modern marine drift. The upward movement by which this was accomplished was not sudden and instantaneous, but gradual and intermittent. The pauses by which it was interrupted are marked by ancient beach-lines, ridges, and terraces, found at different heights above the present lakes. These ridges and terraces are partly due to the denudation and re-arrangement of the materials of the drift itself, which had previously been deposited on the platform, the sloping face of the escarpments, and in the basins of the great lakes.

As soon as the table-land between Lakes Erie and Ontario emerged and was laid dry, the river Niagara came into existence, the basin of Lake Ontario still continuing to form part of the sea. From that moment 
there was a cascade at Queenston of moderate height, which fell directly into the sea. The uppermost limestone and subjacent slate ( 8 and 7 , fig. 4. p. 37.) being exposed, the cataract commenced its retrograde course, while the lower beds in the escarpment (from 6 to 1 ) were still protected from waste by remaining submerged. A second fall would in due time be caused by the continued rise of the land and the exposure of the hard beds ( 6 and 4$)$, constituting what is called the Clinton group, together with the soft and easily undermined red shale (3), on which they repose. Finally, a third cascade would in all likelihood be produced by the rise of another hard mass, the quartzose sandstone (2, fig. 4.) resting on very destructible red shale (1). Three falls, one above the other, very similar in their geological and geographical position to those actually seen on the river Genesee at Rochester, would thus be formed. The recession of the uppermost must have been gradually retarded by the thickening of the incumbent limestone (No. 8, fig. 4), in proportion as the Falls sawed their way southwards. By this means the second cataract, which would not suffer the same retardation, might overtake it, and the two united would then be retarded by the large quantity of rock to be removed, until the lowest fall would come up to them, and then the whole would be united into one.

The principal events enumerated in the above retrospect, comprising the submergence and re-emergence of the Canadian lake district and valley of the St. Lawrence, the deposition of freshwater strata, and the gradual erosion of a ravine seven miles long, are all so modern in the earth's history as to belong to a period when the marine, the fluviatile, and terrestrial 
shells, were the same, or nearly the same, as those now living. Yet if we fix our thoughts on any one portion of this period-on the lapse of time, for example, required for the recession of the Niagara from the escarpment to the Falls,-how immeasurably great will its duration appear in comparison with the sum of years to which the annals of the human race are limited! Had we happened to discover strata, charged with fluviatile shells of recent species, and enclosing the bones and teeth of a Mastodon, near a river at the bottom of some valley, we might naturally have inferred that the buried quadruped had perished at an era long after the canoes of the Indian hunter had navigated the North American waters. Such an inference might easily have been drawn respecting the fossil tusk of the great elephantine quadruped, which I saw taken out of the shell-marl on the banks of the Genesee River near Rochester (see p. 19.). But fortunately on the Niagara, we may turn to the deep ravine, and behold therein a chronometer measuring rudely, yet emphatically, the vast magnitude of the interval of years, which separate the present time from the epoch when the Niagara flowed at a higher level several miles further north across the platform. We then become conscious how far the two events before confounded together,- the entombment of the Mastodon, and the date of the first peopling of the earth by man,--may recede to distances almost indefinitely remote from each other.

But, however much we may enlarge our ideas of the time which has elapsed since the Niagara first began to drain the waters of the upper lakes, we have seen that this period was one only of a series, all belonging to the present zoological epoch; or that in which 
the living testaceous fauna, whether freshwater or marine, had already come into being. If such events can take place while the zoology of the earth remains almost stationary and unaltered, what ages may not be comprehended in those successive tertiary periods during which the Flora and Fauna of the globe have been almost entirely changed! Yet how subordinate a place in the long calendar of geological chronology do the successive tertiary periods themselves occupy! How much more enormous a duration must we assign to many antecedent revolutions of the earth and its inhabitants! No analogy can be found in the natural world to the immense scale of these divisions of past time, unless we contemplate the celestial spaces which have been measured by the astronomer. Some of the nearest of these within the limits of the solar system, as, for example, the orbits of the planets, are reckoned by hundreds of millions of miles, which the imagination in vain endeavours to grasp. Yet one of these spaces, such as the diameter of the earth's orbit, is regarded as a mere unit, a mere infinitesimal fraction of the distance which separates our sun from the nearest star. By pursuing still farther the same investigations, we learn that there are luminous clouds scarcely distinguishable by the naked eye, but resolvable by the telescope into clusters of stars, which are so much more remote, that the interval between our sun and Sirius may be but a fracticn of this larger distance. To regions of space of this higher order in point of magnitude, we may probably compare such an interval of time as that which divides the human epoch from the origin of the coralline limestone over which the Niagara is precipitated at the Falls. Many have been the suc- 
cessive revolutions in organic life, and many the vicissitudes in the physical geography of the globe, and often has sea been converted into land, and land into sea, since that rock was formed. The Alps, the Pyrenees, the Himalaya, have not only begun to exist as lofty mountain chains, but the solid materials of which they are composed have been slowly elaborated beneath the sea within the stupendous interval of ages here alluded to.

The geologist may muse and speculate on these events until, filled with awe and admiration, he forgets the presence of the mighty cataract itself, and no longer sees the rapid motion of its waters, nor hears their sound, as they fall into the deep abyss. But whenever his thoughts are recalled to the present, the tone of his mind,- the sensations awakened in his soul, will be found to be in perfect harmony with the grandeur and beauty of the glorious scene which surrounds him. 


\section{CHAPTER III.}

Tour from the Niagara to the Northern Frontier of Pennsylvania.Ancient Gypsiferous Formation of New York.-Fossil Mastodon at Geneseo.-Scenery.-Sudden Growth of New Towns.-Coal of Blossberg, and resemblance to British Coal Measures.-Stigmaria.-Humming Birds.-Nomenclature of Places.-Helderberg Mountains and Fossils.-Refractory Tenants-Travelling in the States.-Politeness to Women-CCanal-boat.-Domestic Service.Progress of Civilization.-Philadelphia.-Fire-engines.

Sept. 2. 1841.-From Niagara Falls we travelled to the large town of Buffalo, on the shores of Lake Erie, and then passed through Williamsville, Le Roy, and Geneseo, in the State of New York. The horizontal Silurian rocks of this region are in general extremely like those of corresponding age in Europe, consisting of mud-stones and limestone, with similar corals and shells. But there is one remarkable exception;-the occurrence in the middle of the series of a formation of red, green, and bluish grey marls with beds of gypsum, and occasional salt-springs, the whole being from 800 to 1,000 feet thick, and undistinguishable in mineral character from parts of the Upper New Red or Trias of Europe. Near Le Roy I saw these marls and the gypsum exposed to view in quarries. In the overlying limestone at Williamsville were large masses of corals, of the genera Favosites, Cystiphyllum, and others, in the position in which they grew. Some of the species agree with British fossils, but the greater part of them, as I may state on the authority of Mr. Lonsdale, who has studied my specimens, are distinct. 
When at the village of Geneseo, I learnt that ten years before, the bones of a Mastodon had been obtained from a bog in the neighbourhood, and I was desirous of knowing whether any shells accompanied the bones, and whether they were of recent species. Mr. Hall and I therefore procured workmen, who were soon joined by several amateurs of Geneseo, and a pit was dug to the depth of about five feet from the surface. Here we came down upon a bed of white shell-marl and sand, in which lay portions of the skull, ivory tusk, and vertebræ, of the extinct quadruped. The shells proved to be all of existing freshwater and land species now common in this district. I had been told that the Mastodon's teeth were taken out of nuck, or the black superficial peaty earth of this bog. I was therefore glad to ascertain that it was really buried in the shell-marl below the peat, and therefore agreed in situation with the large fossil elks of Ireland, which, though often said to occur in peat, are in fact met with in subjacent beds of marl.

At the Falls of Le Roy, and at the Upper Falls of the River Genesee at Portage, I had opportunities of observing how both of these cascades have been cutting their way backwards through the Silurian rocks, even within the memory of the present settlers. They have each hollowed out a deep ravine with perpendicular sides, bearing the same proportion in volume to the body of water flowing through them which the great ravine of the Niagara does to that river.

Mr. Hall took leave of us at Geneseo, after which I set out on a tour to examine the series of rocks between the upper Silurian strata of the State of New York and the Coal of Pennsylvania. With this view I took 
the direction of Blossberg, where the most northern coal mines of the United States are worked.

On this occasion we left the main road, and entered, for the first time, an American stage-coach, having been warned not to raise our expectations too high in regard to the ease or speed of our conveyance. Accordingly, we found that after much fatigue, we had only accomplished a journey of 46 miles in 12 hours, between Geneseo and Dansville. We had four horses; and when I complained at one of the inns that our coachman seemed to take pleasure in driving rapidly over deep ruts and the roughest ground, it was explained to me that this was the first time in his life he had ever attempted to drive any vehicle, whether two or four-wheeled. The coolness and confidence with which every one here is ready to try his hand at any craft is truly amusing. A few days afterwards I engaged a young man to drive me in a gig from Tioga to Blossberg. On the way, he pointed out, first, his father's property, and then a farm of his own, which he had lately purchased. As he was not yet twenty years of age, I expressed surprise that he had got on so well in the world, when he told me that he had been editor of the "Tioga Democrat" for several years, but had now sold his share of the newspaper.

In the region between Lake Erie and the borders of Pennsylvania, as well as in that immediately south of Lake Ontario, there is an entire want of fine scenery, as might have been anticipated where all the strata are horizontal. The monotony of the endless forest is sometimes relieved by a steep escarpment, a river with wooded islands, or a lake; but the only striking features in the landscape are the waterfalls, and the deep 
chasms hollowed out by them in the course of ages. As the opposite banks of these ravines are on the same level, including that of the Niagara itself, we come abruptly to their edges before we have any suspicion of their existence, and we must travel out of our way to enjoy a sight of them.

At length we reached the water-shed, where the streams flow, on one side, northwards to Lake Ontario, and on the other, southwards, to the Susquehanna. I began to wonder how the Indians ever obtained any correct notions of topography in so continuous a forest, all the smaller rivers, with their islands, being embowered and choked up with trees. I soon ceased to repine at the havoc that was going on in the fine timber which bounded our road on every side.

After traversing successive zones of the Upper Silurian strata, I at length entered at Bath upon the olivecoloured slates and grey sandstone, which seem to be the equivalent of the lower part of the Old Red, or Devonian of England. In this rock some streaks of carbonaceous matter, which soon thin out, and are rarely three inches thick, are met with. I found a proprietor on Spalding's Creek preparing to sink a costly shaft for coal, and I earnestly dissuaded him from his project, referring him to the New York survey. Every seientific man who discourages a favourite mining scheme must make up his mind to be as ill received as the physician who gives an honest opinion that his patient's disorder is incurable.

After the Olive Slate, I came to an incumbent formation of red sandstone near Tioga, and collected fish of two species of Holoptichius, one apparently identical with $H$. nobilissimus, a fossil of the British Old 
Red, and another which, I learn from Sir Philip Egerton, belongs to an entirely new type of this genus. With these were a species of Chelonicthys of large dimensions, a form also very characteristic of the same formation both in Russia and Scotland.

Sept. 5.-At Bath I hired a private carriage for Corning. Although there are two railways here with locomotive engines, one leading to the south, the other for conveying the coal of Blossberg to the Erie canal, I looked in vain for the name of Corning in a newlypublished map, and was informed that the town was only two years old. Already the school-house was finished, the spire of the Methodist church nearly complete, the Presbyterian one in the course of building, the site of the Episcopalian decided on. Wishing to have a carriage, I was taken to a large livery stable, where there were several vehicles and good horses. The stumps of trees, some six feet high, are still standing in the gardens and between the houses. Our innkeeper remarked that the cost of uprooting them would be nearly equal to that of erecting a log-house on the same place. I amused myself by counting the rings of annual growth in these trees, and found that some had been only forty years old when cut down, yet when these began to grow, no white man had approached within many leagues of this valley; most of the older stumps went back no farther than two centuries, or to the landing of the pilgrim fathers, some few to the time of Sir Walter Raleigh, and scarcely one to the days of Columbus. I had before remarked that very ancient trees seemed uncommon in the aboriginal forests of this part of America. They are usually tall and straight, with no grass growing under their dark shade, although 
the green herbage soon springs up when the wood is removed and the sun's rays allowed to penetrate. Some of the stumps, especially those of the fir tribe, take fifty years to rot away, though exposed in the air to alternations of rain and sunshine, a fact on which every geologist will do well to reflect, for it is clear that the trees of a forest submerged beneath the waters, or still more, if entirely excluded from air, by becoming imbedded in sediment, may endure for centuries without decay, so that there may have been ample time for the slow petrifaction of erect fossil trees in the Carboniferous and other formations, or for the slow accumulation around them of a great succession of strata.

I asked the landlord of the inn at Corning, who was very attentive to his guests, to find my coachman. He immediately called out in his bar-room, "Where is the gentleman that brought this man here?" A few days before, a farmer in New York had styled my wife "the woman," though he called his own daughters ladies, and would, I believe, have freely extended that title to their maid-servant. I was told of a witness in a late trial at Boston, who stated in evidence that "while he and another gentleman were shovelling up mud," \&c.; from which it appears that the spirit of social equality has left no other signification to the terms "gentleman" and "lady" but that of "male and female individual."

Sept. 7. Blossberg.-I had now entered Pennsylvania, and reached one of the extreme north-eastern outliers of the great Appalachian coal-field, as Professor Rogers has termed the Coal-measures of Pennsylvania, Ohio, and Virginia. It was the first time I had seen the true "Coal" in America, and I was much struck 
with its surprising analogy in mineral and fossil characters to that of Europe - the same white grits or sandstones as are used for building near Edinburgh and Newcastle-similar black shales, often bituminous, with the leaves of ferns spread out as in an herbarium, the species being for the most part identical with British fossil plants - seams of good bituminous coal, some a few inches, others several yards in thickness-beds and nodules of clay iron-stone; and the whole series resting on a coarse grit and conglomerate, containing quartz pebbles, very like our Millstone Grit, and often called by the American as well as the English miners the "Farewell Rock," because when they have reached it in their borings, they take leave of all valuable fuel. Beneath this grit are those red and grey sandstones already alluded to as corresponding in mineral character, fossils, and position, with our "Old Red."

I was desirous of ascertaining whether a generalisation recently made by Mr. Logan in South Wales could hold good in this country. Each of the Welsh seams of coal, more than ninety in number, have been found to rest on a sandy clay or firestone, in which a peculiar species of plant called Stigmaria abounds, to the exclusion of all others. I saw the Stigmaria at Blossberg, lying in abundance in the heaps of rubbish where coal had been extracted from a horizontal seam. Dr. Saynisch, president of the mine, kindly lighted up the gallery that I might inspect the works, and we saw the black shales in the roof, adorned with beautiful fern leaves, while the floor consisted of an under-clay, in which the stems of Stigmaria, with their leaves or rootlets attached, were running in all directions. The agreement of these phenomena with those of the Welsh 
Coal-measures, 3000 miles distant, surprised me, and lead to conclusions respecting the origin of coal from plants not drifted, but growing on the spot, to which I shall refer in the sequel.

Dr. Saynisch, who was the first to explore the coal in this region, told me that, soon after he settled here, he shot a wolf out of his bedroom window. These animals still commit havoc on the flocks, and last autumn a large panther was killed in the outskirts of Blossberg, but the bears have not been seen for several years. We rode in a hot sunny day to a large clearing in the forest far from any habitation, and I was struck with the perfect silence of the surrounding woods. We heard no call or note of any bird, nothing to remind us of the chirping of the chaffinch or autumnal song of our robin, the grasshoppers and crickets alone keeping up a ceaseless din day and night. The birds here are very abundant, and some are adorned with brilliant plumage, as the large woodpecker, with its crimson head,- - the yellow-bird (Fringilla tristis), of the size of a yellow-hammer, with black wings and a bright yellow body, - the red-bird (Tanagra rubra),-and the Loxia ludovisiana.

A hen humming-bird, far less brilliant in its plumage than the male, flew within a few inches of my face. Its flight and diminutive size reminded me of our humming sphinx, or hawk-moth, like which it remains poised in the air while sucking the flowers, the body seeming motionless, and the wings being invisible from the swiftness of their vibrations. I had before seen one in the wood at Cedarville, sucking the flower of a wild balsam (Impatiens biflora). Dr. Saynisch tells me that on his first visit to these woods, he has known two 
of these birds at a time perch on the edge of a cup of water which he held in his hand, and drink without fear. I was aware from Mr. Darwin's Voyage in the Beagle, that in islands like the Galapagos,

"Where human foot hath ne'er or rarely been,"

the wild birds have no apprehension of danger from man; but here, where for ages the Indian hunters preceded the whites, I am surprised to learn that an instinctive dread of the great "usurper" had not become hereditary in the feathered tribe. I was told, however, that in the hunting grounds called Indian Reservations, within the limits of the settled and civilised states, of which we passed one in New York, the wild animals are comparatively tame, it being a system of the Indians never to molest the game or their prey, except when required for food.

We returned from Blossberg by, the town of Jefferson, and, sailing down Seneca Lake in a steamboat to Geneva, joined the railway, which carried us back again to Albany. At one of the stations where the train stopped we overheard some young women from Ohio exclaim, "Well, we are in a pretty fix!" and found their dilemma to be characteristic of the financial crisis of these times, for none of their dollar notes of the Ohio banks would pass here. The substantive "fix" is an acknowledged vulgarism, but the verb is used in New England by well-educated people, in the sense of the French "arranger" or the English "do." To fix the hair, the table, the fire, means to dress the hair, lay the table, and make up the fire; and this application is, I presume, of Hibernian origin, as an Irish gentleman, King Corney, in Miss Edgeworth's tale of Ormond, says, "I'll fix him and his wounds." 
There are scarcely any American idioms or words which are not of British origin, some obsolete, others provincial. When the lexicographer, Noah Webster, whom I saw at New Haven, was asked how many new words he had coined, he replied one only "to demoralize," and that not for his dictionary, but long before, in a pamphlet published in the last century.

The nomenclature of the places passed through in our short excursion of one month was strange enough. We had been at Syracuse, Utica, Rome, and Parma, had gone from Buffalo to Batavia, and on the same day breakfasted at St. Helena, and dined at Elba. We collected fossils at Moscow, and travelled by Painted Post and Big Flats to Havanna. After returning by Auburn to Albany, I was taken to Troy, a city of 20,000 inhabitants, that I might see a curious landslip which had just happened on Mount Olympus, the western side of that hill, together with a contiguous portion of Mount Ida, having slid down into the Hudson, and caused the death of several persons. Fortunately, some few of the Indian names, such as Mohawk, Ontario, Oneida, Canandaigua, and Niagara, are retained. Although legislative interference in behalf of good taste would not be justifiable, Congress might interpose for the sake of the post-office, and prevent the future multiplication of the same names for villages, cities, counties, and townships. That more than a hundred places should be called Washington is an intolerable nuisance. An Englishman, it is true, cannot complain, for we follow the same system in our colonies ; and it is high time that the postmaster-general brought in a bill for prohibiting new streets in London from receiving names already appropriated and repeated fifty 
times in that same city, to the infinite confusion of the inhabitants and their letter-carriers.

At Troy I visited Professor Eaton, who published in 1824, in his "Survey of the Erie Canal," the earliest account of the Niagara district, dividing the rocks into groups, nearly all of which have been since adopted by the New York surveyors. The mind of this pioneer in American geology was still in full activity, and his zeal unabated; but a few months after my visit he died at an advanced age.

I next examined, in company with Mr. Hall, two swamps, situated in Albany and Greene counties, west of the Hudson river, where the remains of a Mastodon occurred, in both places at the depth of four or five feet, in shell-marl, with recent species of shells. These deposits of marl covered with peat are newer than the boulder formation, and cattle have very lately been mired in the same bogs. In similar situations in Scotland and England we find only the remains of existing mammalia; and although on the banks of the Thames and elsewhere we discover the bones of the extinct elephant and rhinoceros associated with recent land and freshwater shells (mingled, however, with some few exotic species), the strata in which they lie do not belong precisely, like those in New York, to the most modern geographical condition of the country.

We then made a tour to the Helderberg Mountains, S. W. of Albany, to see the Upper Silurian strata, and to study their fossils in the museum of Mr. Gebhard at Schoharie. The depth of the valleys, and some precipitous cliffs of limestone, render this region more picturesque than is usual where the strata are undisturbed. I rejoiced to see the sugar-maple (Acer saccharinus), 
an ornamental tree, spared in the new clearings. The sap from which sugar is made was everywhere trickling down into wooden troughs from gashes made in the bark. The red maples were now beginning to assume their bright autumnal tints, but the rest of the forest was as verdant as ever; a blue Lobelia, which we had gathered at the Falls of Niagara, was still in bloom, together with many white and blue asters which had only just come out. The most elegant flower in the woods at this season is the fringed gentian (Gentiana crinita).

" Bright with Autumn dew,

And colour'd with the Heaven's own blue."

One day at Schoharie, a hawk pounced down from a lofty tree, and seized a striped squirrel on the ground, within three yards of our party. It was bearing off its burden with ease, until, alarmed by our shouts, it dropped the squirrel, which ran off apparently unhurt. I observed early in the morning myriads of cobwebs extending from one blade of grass to another, as we often see them on an English lawn before the dew is dried up.

On our way back from Schoharie to Albany, we found the country people in a ferment, a sheriff's officer having been seriously wounded when in the act of distraining for rent, this being the third year of the "Helderberg war," or a successful resistance by an armed tenantry to the legal demands of their landlord, Mr. Van Renssalaer. It appears that a large amount of territory on both sides of the river Hudson, now supporting, according to some estimates, a population of 100,000 souls, had long been held in fee by the Van Renssalaer family, the tenants paying a small ground 
rent. This system of things is regarded by many as not only injurious, because it imposes grievous restraints upon alienation, but as unconstitutional, or contrary to the genius of their political institutions, and tending to create a sort of feudal perpetuity. Some of the leases have already beên turned into fees, but many of the tenants were unable or unwilling to pay the prices asked for such conveyances, and declared that they had paid rent long enough, and that it was high time that they should be owners of the land.

A few years ago, when the estates descended from the late General Van Renssalaer to his sons, the attempt to enforce the landlord's rights met with open opposition. The courts of law gave judgment, and the sheriff of Albany having failed to execute his process, at length took military force in 1839 , but with no better success. The governor of New York was then compelled to back him with the military array of the state, about 700 men, who began the campaign at a day's notice in a severe snow storm. The tenants are said to have mustered against them 1500 strong, and the rents were still unpaid, when in the following year, 1840 , the governor, courting popularity, as it should seem, while condemning the recusants in his message, virtually encouraged them by recommending their case to the favourable consideration of the state, hinting at the same time at legislative remedies. The legislature, however, to their credit, refused to enact these, leaving the case to the ordinary courts of law.

The whole affair is curious, as demonstrating the impossibility of creating at present in this country a class of landed proprietors deriving their income from the letting of lands upon lease. Every man must oc- 
cupy his own acres. He who has capital enough to stock a farm can obtain land of his own so cheap as naturally to prefer being his own landlord.

Sept. 27. 1841.-We embarked once more on the Hudson, to sail from Albany to New York, with several hundred passengers on board, and thought the scenery more beautiful than ever. The steam-boat is a great floating hotel, of which the captain is landlord. He presides at meals, taking care that no gentlemen take their places at table till all the ladies, or, as we should say in England, the women of every class, are first seated. The men, by whom they are accompanied, are then invited to join them, after which, at the sound of a bell, the bachelors and married men travelling en garçon pour into the saloon, in much the same style as members of the House of Commons rush into the Upper House to hear a speech from the throne.

One of the first peculiarities that must strike a foreigner in the United States is the deference paid universally to the sex, without regard to station. Women may travel alone here in stage-coaches, steam-boats, and railways, with less risk of encountering disagreeable behaviour, and of hearing coarse and unpleasant conversation, than in any country I have ever visited. The contrast in this respect between the Americans and the French is quite remarkable. There is a spirit of true gallantry in all this, but the publicity of the railway car, where all are in one long room, and of the large ordinaries, whether on land or water, is a great protection, the want of which has been felt by many a female traveller without escort in England. As the Americans address no conversation to strangers, we soon became tolerably reconciled to living so much in 
public. Our fellow-passengers consisted for the most part of shopkeepers, artizans, and mechanics, with their families, all well-dressed, and so far as we had intercourse with them, polite and desirous to please. A large part of them were on pleasure excursions, in which they delight to spend their spare cash.

On one or two occasions during our late tour in the newly-settled districts of New York, it was intimated to us that we were expected to sit down to dinner with our driver, usually the son or brother of the farmer who owned our vehicle. We were invariably struck with the propriety of their manners, in which there was selfrespect without forwardness. The only disagreeable adventure in the way of coming into close contact with low and coarse companions, arose from my taking places in a cheap canal-boat near Lockport, partly filled with emigrants, and corresponding somewhat in the rank of its passengers with a third-class railway-carriage in England. "Que diable allait-il faire dans cette galère?" would have been a difficult question for me to answer, especially as I afterwards learnt that I might have hired a good private carriage at the very place where $\mathbf{I}$ embarked. This convenience indeed, although there is no posting, I invariably found at my commiand in all the states of the Union, both northern and southern, which I visited during my stay in America.

Travellers must make up their minds, in this as in other countries, to fall in now and then with free and easy people. I am bound, however, to say that in the two most glaring instances of vulgar familiarity which we have experienced here, we found out that both the offenders had crossed the Atlantic only ten years before, and had risen rapidly from a humble station. What- 
ever good breeding exists here in the middle classes is certainly not of foreign importation; and John Bull, in particular, when out of humour with the manners of the Americans, is often unconsciously beholding his own image in the mirror, or comparing one class of society in the United States with another in his own country, which ought, from superior affluence and leisure, to exhibit a higher standard of refinement and intelligence.

We have now seen the two largest cities, many towns and villages, besides some of the back settlements, of New York and the New England States; an exemplification, I am told, of a population amounting to about five millions of souls. We have met with no beggars, witnessed no signs of want, but everywhere the most unequivocal proofs of prosperity and rapid progress in agriculture, commerce, and great public works. As these states are, some of them, entirely free from debt, and the rest have punctually paid the interest of Government loans, it would be most unjust to apply to them the disparaging comment "that it is easy to go ahead with borrowed money." In spite of the constant influx of uneducated and pennyless adventurers from Europe, I believe it would be impossible to find five millions in any other region of the globe whose average moral, social, and intellectual condition stands so high. One convincing evidence of their wellbeing has not, I think, been sufficiently dwelt upon by foreigners: I allude to the difficulty of obtaining and retaining young American men and women for a series of years in domestic service, an occupation by no means considered as degrading here, for they are highly paid, and treated almost as equals. But so long as they en- 
joy such facilities of bettering their condition, and can marry early, they will naturally renounce this bondage as soon as possible. That the few, or the opulent class, especially those resident in country places, should be put to great inconvenience by this circumstance, is unavoidable, and we must therefore be on our guard, when endeavouring to estimate the happiness of the many, not to sympathise too much with this minority.

I am also aware that the blessing alluded to, and many others which they enjoy, belong to a progressive, as contrasted with a stationary, state of society; - that they characterize the new colony, where there is abundance of unoccupied land, and a ready outlet to a redundant labouring class. They are not the results of a democratic, as compared with a monarchical or aristocratic constitution, nor the fruits of an absolute equality of religious sects, still less of universal suffrage. Nevertheless, we must not forget how easily all the geographical advantages arising from climate, soil, fine navigable rivers, splendid harbours, and a wilderness in the far West, might have been marred by other laws, and other political institutions. Had Spain colonized this region, how different would have been her carees of civilisation! Had the puritan fathers landed on the banks of the Plata, how many hundreds of large steamers would ere this have been plying the Paranà and Uruguay,-how many railway-trains flying over the Pampas,-how many large schools and universities flourishing in Paraguay!

Sept. 28.-We next went by railway from New York to Philadelphia through the state of New Jersey. Large fields of maize, without the stumps of trees rising above the corn, and villas with neat flower-gardens, 
seemed a novelty to us after the eye had dwelt for so many hundreds of miles on native forests and new clearings. The streets of Philadelphia rival the finest Dutch towns in cleanliness, and the beautiful avenues of various kinds of trees afford a most welcome shade in summer. We were five days here, and every night there was an alarm of fire, usually a false one; but the noise of the firemen was tremendous. At the head of the procession came a runner blowing a horn with a deep unearthly sound, next a long team of men (for no horses are employed) drawing a strong rope to which the ponderous engine was attached with a large bell at the top, ringing all the way; next followed a mob, some with torches, others shouting loudly; and before they were half out of hearing, another engine follows with a like escort; the whole affair resembling a scene in Der Freischutz or Robert le Diable, rather than an act in real life. It is, however, no sham, for these young men are ready to risk their lives in extinguishing a fire; and as an apology for their disturbing the peace of the city when there was no cause, we were told "that the youth here require excitement!" They manage these matters as effectively at Boston without turmoil. 


\section{CHAPTER IV.}

Excursion to New Jersey.-Cretaceaus Rocks compared to European. -General Anulogy of Fossils, and Distinctness of Species.-Tour to the Anthracite Region of the Alleghanies in Pennsylvania.Long parallel Ridges and Valleys of these Mountains.-Pottsville. -Absence of Smoke.-Fossil Plants same as in Bituminous Coal. -Stigmaria.-Great Thickness of Strata.-Origin of Anthracite. -Vast Area of the Appalachian Coal-field.-Progressive Debituminization of Coal from West to East.-General Remarks on the different Groups of Rocks between the Allantic and the Mississippi.-Law of Structure of the Appalachian Chain discovered by the Professors Rogers.-Increased Folding and Dislocation of Strata on the South-eastern Flank of the Appalachians.-Theory of the Origin of this Mountain Chain.

Cretaceous Strata of New Jersey.

Sept. 30, 1841.-From Philadelphia I made a geological excursion of several days, to examine the cretaceous strata of New Jersey, in company with Mr. Conrad, to whom we are indebted for several valuable works on the fossil shells of the tertiary, cretaceous, and Silurian strata of the United States. We went first to Bristol on the Delaware to visit Mr. Vanuxem, then engaged in preparing for publication his portion of the State Survey of New York; next by Bordentown to New Egypt, and returned by the Timber Creek, recrossing the Delaware at Camden.

Although in this part of New Jersey there is no white chalk with flints, so characteristic of rocks of this age in Europe, it is still impossible to glance at the fossils, and not to be convinced that Dr. Morton was right 
in referring in 1834 the New Jersey deposits to the European cretaceous era. He and Mr. Conrad remarked that the American species of shells were nearly all new, or distinct from those before described, and yet very analogous to those of cretaceous strata already known. The New Jersey rocks have been separated into five subdivisions, but of these two only have proved sufficiently rich in organic remains to admit of their being compared with corresponding strata in distant regions. The lower of these consists in great part of green sand and green marl, and was supposed by Dr. Morton to be the equivalent of the English "Green sand;" while an upper or calcareous rock, composed chiefly of a soft straw-coloured limestone with corals, was thought to correspond with the white chalk of Europe. But after carefully comparing my collection, comprising about 60 species of "shells, besides many corals and other remains, I have arrived at the conclusion that the whole of the New Jersey series agrees in its chronological relations with the European white chalk, or, to speak more precisely, with the formations ranging from the Gault to the Maestricht beds inclusive. Among the shells, in determining which I have been assisted by Professor E. Forbes, not more than four out of sixty seem to be quite identical with European species. These are Belemnites mucronatus, Pecten quinquecostatus, Ostrea falcata (O. larva, Goldfuss), and $\boldsymbol{O}$. vesicularis. Several others, however, approach very near to, and may be the same as European shells, as for example Trigonia thoracica, and at least fifteen may be regarded as good geographical representatives of well-known chalk fossils, belonging, for the most part, to beds above the Gault 
in Europe. There are a few very peculiar forms among the American testacea, such as T'erebrritula Sayii (Morton).

In the upper or straw-coloured limestone, I found, on the banks of the Timber Creek, twelve miles southeast of Philadelphia, six species of corals and several echinoderms, chiefly allied to Upper Cretaceous forms. The same calcareous stratum also abounds in foraminifera, characteristic of the chalk, comprising, among others, the genera Cristellaria, Rotalina, and Nodosaria. Mr. Owen has recognised, in the fossil reptiles from New Jersey, not only the vertebræ of Mosasaurus, previously noticed by Dr. Morton, but also the Pliosaurus, and a large crocodile of the Procœlian division, or having its vertebræ like the living species, with the anterior surface concave. There are also many fish of the shark family, analogous to those of the English chalk, and the Galeus pristodontus is represented by a species very closely allied, if not identical.

Upon the whole, the list of genera, and the forms of the species, are remarkably analogous to the cretaceous group of Europe; and the agreement of four or five species of Mollusca, being in the proportion of about seven in the hundred, implies no inconsiderable amount of affinity at a distance of between 3000 and 4000 miles from the corresponding assemblage of fossils in Central and Northern Europe, especially when we recollect that there is a difference in latitude of more than ten degrees between the two districts compared. Some of the species common to the opposite sides of the Atlantic, are those which in Europe have the greatest vertical range, as Pecten quinquecostatus, 
ChAP. IV. TOUR TO THE ANTHRACITE REGION.

and which might therefore be expected to recur in distant parts of the globe.

At the same time we learn from the facts above mentioned, that the marine fauna, whether vertebrate or invertebrate, testaceous or zoophytic, was divided at the remote epoch under consideration, as it is now, into distinct geographical provinces, although the geologist may everywhere recognise the cretaceous type, whether in Europe or America, and I might add, India. This peculiar type exhibits the preponderating influence of a vast combination of circumstances, prevailing at one period throughout the globe-circumstances dependent on the state of the physical geography, climate, and the organic world in the period immediately preceding, together with a variety of other conditions too long to enumerate here. It would not be difficult for a naturalist to point out the characters stamped on the living Flora and Fauna, by which they also might be distinguished as a whole from those of all former geological epochs. The resemblance of the corals, shells, and insects, of certain temperate regions of the southern hemisphere (Van Dieman's Land, for example), to those of the temperate zone north of the equator, or the close analogy of the arctic and antarctic fauna, the species in both cases being quite different, are illustrations of the common type here alluded to, which is evidently caused or controlled by some general law, and by some mutual relation existing between the animate creation and the state of the habitable surface at any given period.

\section{Anthracite Formation of Pennsyluania.}

Oct. 3.-Having already seen the carboniferous stra- 
ta at Blossberg in Pennsylvania, where they are very slightly disturbed, and where the coal is bituminous, I was desirous of examining some of the great mines of anthracite coal which occur in the midst of the most bent and inclined strata of the Alleghany mountains. Professor H. D. Rogers, who, with an able corps of assistants, had now nearly brought to a close his elaborate State Survey of Pennsylvania, kindly offered to be my guide, which enabled me in a comparatively short time to obtain an insight into the geological structure of this chain. We first followed the course of the Schuylkill River, passing through a country moderately elevated (B, C, fig. 5. p. 74.), with hills between 200 and 300 feet above the sea, where the rocks consisted chiefly of gneiss. As we went westward we entered a belt, about twenty-five miles broad, of red sandstone and trap (New Red), similar to that before mentioned at New Haven. Having traversed these granitic and secondary formations, we arrived at Reading, fifty-two miles N. W. of Philadelphia, and were then at the base of the easternmost of the great parallel ridges which constitute the Alleghanies or Appalachian chain of mountains. The rocks of this chain consist of the Silurian, Devonian, and Carboniferous groups, which are folded as if they had been subjected to a great lateral pressure when in a soft and yielding state, large portions having been afterwards removed by denudation. No traveller can fail to remark the long and uniform parallel ridges, with intervening valleys, like so many gigantic wrinkles and furrows, which mark the geographical outline of this region; and these external features are found by the geologist to be intimately connected with the internal arrangement of the 
stratified rocks. The long and narrow ridges, rarely rising more than 2000 feet above the valleys, and usually not more than half that height, are broken here and there by transverse fissures, which give passage to rivers, and by one of which the Schuylkill flows out at Reading. The strata are most disturbed on the southeastern flank of the mountain chain, where we first entered, and they become less and less broken and inclined as they extend westward.

After passing several belts of the inferior fossiliferous strata, we came to the Anthracite coal-measures of Pottsville on the Schuylkill. Here I was agreeably surprised to see a flourishing manufacturing town with the tall chimneys of numerous furnaces, burning night and day, yet quite free from smoke. Leaving this clear atmosphere, and going down into one of the mines, it was a no less pleasing novelty to find that we could handle the coal without soiling our fingers. The slow combustion of anthracite can be overcome by a strong current of air, not only in large furnaces, but by aid of a blower in the fire-places of private dwellings, and its drying effect on the air of a room may be counteracted by the evaporation of water. As managed by the Americans, I have no hesitation in preferring its use, in spite of the occasional stove-like heat produced by it, to that of bituminous coal in London, coupled with the penalty of living constantly in a dark atmosphere of smoke, which destroys our furniture, dress, and gardens, blackens our public buildings, and renders cleanliness impossible.

In the neighbourhood of Pottsville, there are no less than thirteen seams of anthracite coal, several of which are more than two yards thick. Some of the lowest 
of these alternate with white grits and a conglomerate of coarser texture than I had ever seen in any productive coal-measures, some of the pebbles of quartz being of the size of a hen's egg. I was curious to know whether the Stigmariæ would be found here in the underclays, as at Blossberg before-mentioned, situated 120 miles to the westward. It was easy to ascertain the fact, for several of the coal seams, from eight to ten feet thick, were quarried in the open air, and the strata being vertical, a void space was left after the removal of the fuel, like a straight open fissure, in which we could walk, and see, in the wall on the one side, a stratum originally above, and on the other, that which had been immediately below the coal. On the former, or what is usually termed the roof, were shales with distinct impressions of ferns; among others, the British species Pecopteris lonchitica and Neuropteris cordata, together with trunks and stems of Sigillaria, Lepidodendron, and Calamites; while on the opposite or south-eastern side, was an underclay with numerous Stigmariæ, often several yards, and even in some cases thirty feet long, with their leaves or rootlets attached.

In this coal-field, as in all the others hitherto observed in America, particular seams of coal are found to be far more persistent than the accompanying beds of shale, sandstone, or limestone. As we proceeded from Pottsville, by Tamaqua, to the Lehigh Summit Mine, we found the beds of grit and shale gradually to thin out, so that several beds of anthracite, at first widely separated, were brought nearer and nearer together, until they united, and formed one mass about fifty feet thick, without any greater interpolated matter 
Chap. iv. GReat Thickness of STRata.

than two thin layers of clay with Stigmariæ. At Mauch Chunk, or the Bear Mountain, this remarkable bed of anthracite is quarried in the open air, and removed bodily together with the overlying sandstone, forty feet thick, the summit of the hill being "scalped," as one of the miners expressed it. The vegetable matter, which is represented by this enormous mass of anthracite, must, before it was condensed by pressure and the discharge of its hydrogen, oxygen, and other volatile ingredients, have been probably between 200 and 300 feet thick. The accumulation of such a thickness of the remains of plants, so unmixed with earthy ingredients, would be most difficult to explain on the hypothesis of their having been drifted into the place they now occupy; but it becomes intelligible if we suppose them to have grown on the spot. Whether we regard the Stigmariæ as roots, according to the opinion of M. Adolphe Brongniart and Mr. Binney, or embrace the doctrine of their being aquatic plants, no one can doubt that they at least are fossilised on the very spot where they grew; and as all agree that they are not marine plants, they go far to establish the doctrine of the growth in situ of the materials of the overlying coal seams.

The prodigious thickness of the carboniferous rocks in this part of the Appalachian chain, is in harmony with the theory already alluded to, which requires the repeated sinking down of many successive terrestrial surfaces, allowing an indefinite quantity of sediment to be superimposed vertically in one continuous series of beds. The surveys of Pennsylvania and Virginia show that the south-east was the quarter whence the coarser materials of the carboniferous rocks were derived, and 
there are proofs that the ancient land lay in that direction. The conglomerate which forms the general base of the coal-measures is 1500 feet thick in the Sharp Mountain, where I saw it, near Pottsville; whereas it has only a thickness of 500 feet, about thirty miles to the north-west, and dwindles gradually away when followed still farther in the same direction, till its thickness is reduced to thirty feet. (Rogers. Trans. Assoc. Amer. Geol., 1840-42, p. 440.) The limestones, on the other hand, of the coal-measures, augment as we trace them westward. Similar observations have been made in regard to the Silurian and Devonian formations in New York; the sandstones and all the mechanically-formed rocks thinning out as they go westward, and the limestones thickening, as it were, at their expense. It is, therefore, clear that the ancient land was to the east; the deep sea, with its banks of coral and shells, to the west.

I at first supposed that some deception might have arisen respecting the alleged thickness of the older fossiliferous rocks of the Appalachians, owing to the dislocations and inverted position of the beds, but I was soon convinced that due regard had been paid to the apparent repetitions caused by these disturbances, and I have little doubt that those Silurian and Devonian strata, which do not exceed in their aggregate thickness a mile and a half in the State of New York, acquire more than three times that thickness in the Pennsylvanian Alleghanies.

A few days' observation of the identity of the fossil plants, and the relative position of the anthracite, satisfied me that it was of the same age as the bituminous coal which I had seen at Blossberg. This opinion was, 
I believe, first promulgated by Mr. Featherstonehaugh in 1831, at a time when many geologists were disposed to assign a higher antiquity to the anthracite than to the bituminous coal-measures of the United States. The recent surveys have now established this fact beyond all question, and hence it becomes a subject of great interest to inquire how these two kinds of fuel, originating as they did from precisely the same species of plants, and formed at the same period, should have become so very different in their chemical composition. In the first place, I may mention that the anthracite coal-measures above alluded to, occurring in the eastern or most disturbed part of the Appalachian chain, are fragments or outliers of the great continuous coal-field of Pennsylvania, Virginia, and Ohio, which occurs about forty miles to the westward. This coal-field is remarkable for its vast area, for it is described by Professor H. D. Rogers as extending continuously from N. E. to S. W., for a distance of 720 miles, its greatest width being about 180 miles. On a moderate estimate its superficial area amounts to 63,000 square miles. It extends from the northern border of Pennsylvania as far south as near Huntsville in Alabama.

This coal formation, before its original limits were reduced by denudation, must have measured, at a reasonable calculation, 900 miles in length, and in some places more than 200 miles in breadth. By reference to the section (fig 5., p. 74.), it will be seen that the strata of coal are horizontal to the westward of the mountain in the region $\mathrm{D}, \mathrm{E}$, and become more and more inclined and folded as we proceed eastward. Now it is invariably found, as Professor H. D. Rogers has shown by chemical analysis, that the coal is most 
bituminous towards its western limit, where it remains level and unbroken, and that it becomes progressively debituminized as we travel south-eastward towards the more bent and distorted rocks. Thus, on the Ohio, the proportion of hydrogen, oxygen, and other volatile matters, ranges from forty to fifty per cent. Eastward of this line, on the Monongahela, it still approaches forty per cent., where the strata begin to experience some gentle flexures. On entering the Alleghany Mountains, where the distinct anticlinal axes begin to show themselves, but before the dislocations are considerable, the volatile matter is generally in the proportion of eighteen or twenty per cent. At length, when we arrive at some insulated coal-fields (5', fig. 5.) associated with the boldest flexures of the Appalachian chain, where the strata have been actually turned over, as near Pottsville, we find the coal to contain only from six to twelve per cent. of bitumen, thus becoming a genuine anthracite. (Trans. of Ass. of Amer. Geol., p. 470.)

It appears from the researches of Liebig and other eminent chemists, that when wood and vegetable matter are buried in the earth, exposed to moisture, and partially or entirely excluded from the air, they decompose slowly and evolve carbonic acid gas, thus parting with a portion of their original oxygen. By this means, they become gradually converted into lignite or wood-coal, which contains a larger proportion of hydrogen than wood does. A continuance of decomposition changes this lignite into common or bituminous coal, chiefly by the discharge of carburetted hydrogen, or the gas by which we illumine our streets and houses. According to Bischoff, the inflammable gases which 
are always escaping from mineral coal, and are so often the cause of fatal accidents in mines, always contain carbonic acid, carburetted hydrogen, nitrogen, and olifiant gas. The disengagement of all these gradually transforms ordinary or bituminous coal into anthracite, to which the various names of splint coal, glance coal, culm, and many others, have been given.

We have seen that, in the Appalachian coal-field, there is an intimate connection between the extent to which the coal has parted with its gaseous contents, and the amount of disturbance which the strata have undergone. The coincidence of these phenomena may be attributed partly to the greater facility afforded for the escape of volatile matter where the fracturing of the rocks had produced an infinite number of cracks and crevices, and also to the heat of the gases and water penetrating these cracks, when the great movements took place, which have rent and folded the Appalachian strata. It is well known that, at the present period, thermal waters and hot vapours burst out from the earth during earthquakes, and these would not fail to promote the disengagement of volatile matter from the carboniferous rocks.

Structure and Origin of the Appalachian Chain.

The subjects discussed in the preceding pages, lead me naturally to say something respecting the structure of the Appalachian chain, and its geological relations to the less elevated regions east and west of it. The annexed ideal section (fig. 5.), to which I shall have frequently occasion to refer in the sequel, will give some notion of the principal phenomena, omitting a great 


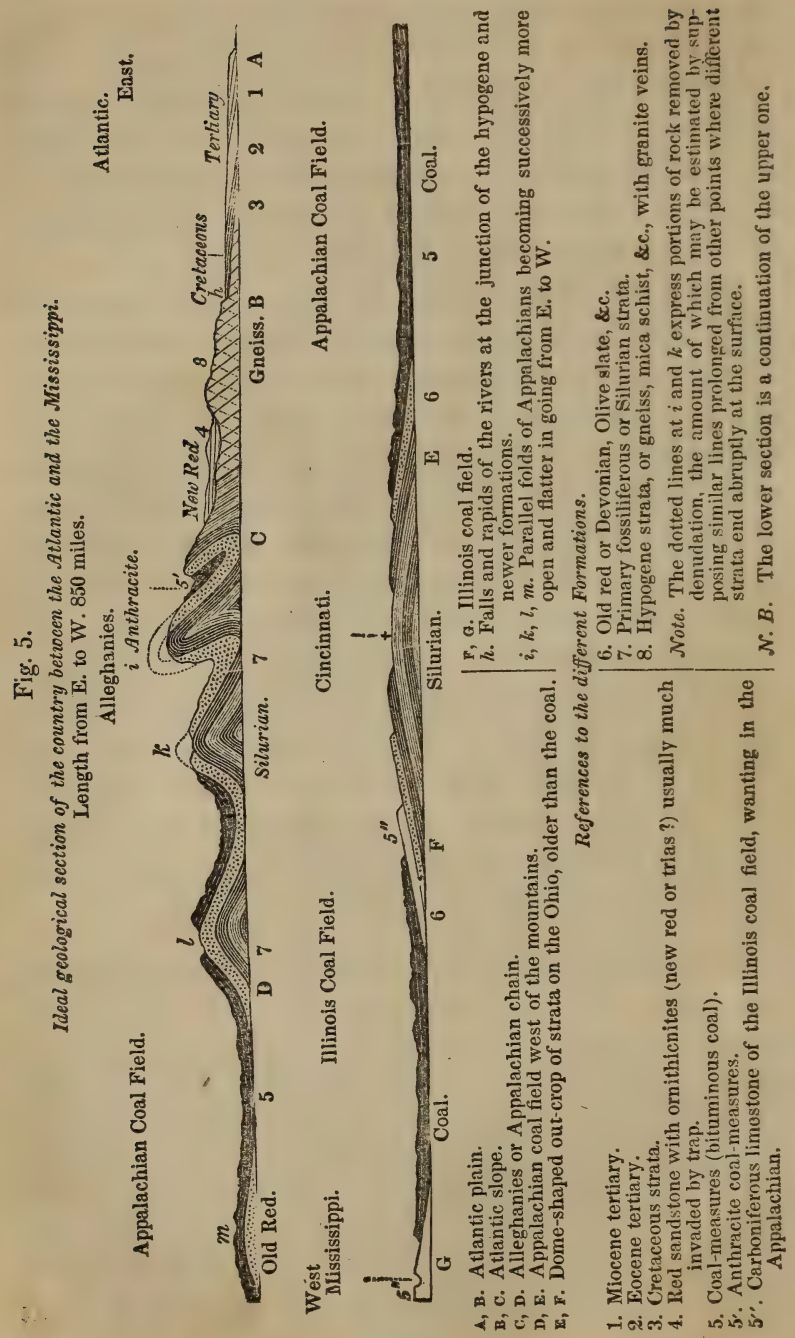


number of details. Starting from the shores of the Atlantic, on the eastern side of the Continent, we first come to a low region (A, B), which was called the alluvial plain by the first geographers. It is occupied by tertiary and cretaceous strata nearly horizontal, and containing in general no hard and solid rocks, and is usually not more than from 50 to 100 feet high, from New Jersey to Virginia. In these states this zone is not many leagues in breadth, but it acquires a breadth of 100 and 150 miles in the Southern States, and a height of several hundred feet towards its western limits. The next belt, from B to $\mathrm{c}$, consists of granitic rocks (hypogene), chiefly gneiss and micaschist, covered occasionally with unconformable red sandstone, No. 4 (New Red ?), remarkable for its ornithicnites. Sometimes also this sandstone rests on the edges of the disturbed paleozoic rocks (as seen in the Section). The region (B, C), sometimes called the "Atlantic Slope," corresponds nearly in average width with the low and flat plain $(\mathrm{A}, \mathrm{B})$, and is characterised by hills of moderate height, contrasting strongly, in their rounded shape and altitude, with the long, steep, and lofty parallel ridges of the Alleghany mountains. The out-crop of the strata in these ridges, like the two belts of hypogene and newer rocks $(\mathrm{A}, \mathrm{B}$, and $\mathrm{B}, \mathrm{C})$, above alluded to, when laid down on a geological map, exhibit long stripes of different colours, running in a N. E. and S. W. direction, in the same way as the lias, chalk, and other secondary formations in the middle and eastern half of England.

The narrow and parallel zones of the Appalachians here mentioned consist of strata, folded into a succession of convex and concave flexures, subsequently laid 
open by denudation. The component rocks are of great thickness, all referable to the Silurian, Devonian, and Carboniferous formations. There is no principal or central axis, as in the Pyrenees and many other chains - no nucleus to which all the minor ridges conform; but the chain consists of many nearly equal and parallel foldings, having what the geologists term an anticlinal and synclinal arrangement. This system of hills extends, geologically considered, from Vermont to Alabama, being more than 1000 miles long, from 50 to 150 miles broad, and varying in height from 2000 to 6000 feet. Sometimes the whole assemblage of ridges runs perfectly straight for a distance of more than 50 miles, after which all of them wheel round together, and take a new direction, at an angle of 20 or 30 degrees to the first.

Mr. R. C. Taylor had made considerable progress in unravelling the structure of certain portions of this chain, before the commencement of the State Surveys of Virginia and Pennsylvania, the former conducted by Professor W. B. Rogers, the latter by his brother, Professor H. D. Rogers, both aided by a numerous corps of assistants. To these elaborate and faithful surveys we owe the discovery of the clue to the general law of structure prevailing throughout this important range of mountains, which, however simple it may appear when once made out and clearly explained, might long have been overlooked, amidst so great a mass of complicated details. It appears that the bending and fracture of the beds is greatest on the south-eastern or Atlantic side of the chain, and the strata become less and less disturbed as we go westward, until at length they regain their original or horizontal position. By 
reference to the section (fig. 5.), it will be seen that on the eastern side, or on the ridges and troughs nearest the Atlantic, the south-eastern dips predominate, in consequence of the beds having been folded back upon themselves, as in $i$, those on the north-western side of each arch having been inverted. The next set of arches (such as $k$ ) are more open, each having its western side steepest; the next $(l)$ opens out still more widely, the next $(m)$ still more, and this continues until we arrive at the low and level part of the Appalachian coal-field ( $\mathrm{D}, \mathrm{E})$.

In nature, or in a true section, the number of bendings or parallel folds is so much greater that they could not be expressed in a diagram without confusion. It is also clear that large quantities of rock have been removed by aqueous action or denudation, as will appear if we attempt to complete all the curves in the manner indicated by the dotted lines at $i$ and $k$.

The movements which imparted so uniform an order of arrangement to this vast system of rocks must have been contemporaneous, or belonging to one and the same series, depending on some common cause. Their geological date is unusually well defined. We may declare them to have taken place after the deposition of the carbutiferous strata (No. 5.), and before the formation of the red sandstone (No. 4.). The greatest disturbing and denuding forces have evidently been exerted on the south-eastern side of the chain, and it is here that igneous or plutonic rocks are observed to have invaded the strata, forming dykes, some of which run for miles in lines parallel to the main direction of the Appalachians, or N.N.E. and S.S.W.

According to the theory of the Professors Rogers, the 
wave-like flexures, above alluded to, are explained by supposing the strata, when in a plastic state, to have rested on a widely-extended surface of fluid lava, and elastic vapours and gases. The billowy movement of this subterranean sea of melted matter imparted its undulations to the elastic overlying crust, which was enabled to retain the new shapes thus given to it by the consolidation of the liquid matter injected into fissures.*

For my own part, I cannot imagine any real connection between the great parallel undulations of the rocks and the real waves of a subjacent ocean of liquid matter, on which the bent and broken crust may once have rested. That there were great lakes, or seas of lava, retained by volcanic heat for ages, in a liquid state beneath the Alleghanies, is highly probable, for the simultaneous eruptions of distant vents in the Andes leave no doubt of the wide subterranena areas permanently occupied by sheets of fluid lava in our own times. It is also consistent with what we know of the laws governing volcanic action to assume that the force operated in a linear direction, for we see trains of volcanic vents breaking out for hundreds of miles along a straight line, and we behold long parallel fissures, often nilleù wili trap ữ cunsolidated lava, holding a straight course for great distances through rocks of all ages. The causes of this peculiar mode of development are as yet obscure and unexplained; but the existence of long narrow ranges of mountains, and of great faults and vertical shifts in the strata prolonged for great distances in certain directions, may all be results of the same kind of action. It also accords weమ

* Trans. of Ass, of Amer, Geol., 1840-2, p. 515. 
with established facts to assume that the solid crust overlying a region where the subterranean heat is increasing in intensity, becomes gradually upheaved, fractured, and distended, the lower part of the newly opened fissures becoming filled with fused matter, which soon consolidates and crystallizes. These uplifting movements may be propagated along narrow belts, placed side by side, and may have been in progress simultaneously, or in succession, in one narrow zone after another.

When the expansive force has been locally in operation for a long period, in a given district, there is a tendency in the subterranean heat to diminish; - the volcanic energy is spent, and its position is transferred to some new region. Subsidence then begins, in consequence of the cooling and shrinking of subterranean seas of lava and gaseous matter: and the solid strata collapse in obedience to gravity. If this contraction take place along narrow and parallel zones of country, the incumbent flexible strata would be forced, in proportion as they were let down, to pack themselves into a smaller space, as they conformed to the circumference of a smaller arc. The manner in which undulations may be gradually produced in pliant strata by subsidence is illustrated on a small scale by the creeps in coal-mines; there both the overlying and underlying shales and clays sink down from the ceiling, or rise up from the floor, and fill the galleries which have been left vacant by the abstraction of the fuel.* In like manner the failure of support arising from subterranean causes may enable the force of gravity, though origi.

* See "Elements of Geology," by the author. $2 d$ ed. vol. i., p. 110-Boston ed. vol. i. p. 108, 
nally exerted vertically, to bend and squeeze the rocks as if they had been subjected to lateral pressure.

"Earthquakes have raised to heaven the humble vale, And gulphs the mountain's mighty mass entomb'd, And where th' Atlantic rolls, wide continents have bloom'd."

In applying these lines to the physical revolutions of the territory at present under consideration, we must remember that the continent which bloomed to the eastward, or where the Atlantic now rolls its waves (see p. 70.), was anterior to the origin of the carboniferous strata which were derived from its ruins; whereas the elevation and subsidence supposed to have given rise to the Appalachian ridges was subsequent to the deposition of the coal-measures. But all these great movements of oscillation were again distinct from the last upheaval which brought up the whole region above the level of the sea, laying dry the horizontal New Red Sandstone (No. 4., fig. 5.), as well as a great part of, if not all, the Appalachian chain.

The largest amount of denudation is found, as might have been expected, on the south-eastern side of the chain, where the force of expansion and contraction, of elevation and subsidence, has been greatest. The first set of denuding operations may have taken place when the strata, including the carboniferous, were first raised above the sea; a second, whien iney sain ugwan, third, when the Red Sandstone (No.4.), after it had been thrown down on the truncated edges of the older strata, participated in the waste. The great extent of solid materials thus removed, must add, in no small dogreo, to the diffeuity of restoring in imagination the successive changes which have occurred, and of accounting in a satisfactory manner for the origin of this mountain chain. 
Char. v. WOODED RIDGES OF ALLEGHANIES. 81

\section{CHAPTER V.}

Wooded Ridges of the Alleghany Mountains.-German Patois in Pennsylvania.-Lehigh Summit Mine--Effects of Ice during a Flood on the Delaware.-Election of a Governor at Trenton and at Philadelphia.-Journey to Boston.-Autumnal Tints of the Foliage.-Boston the Seat of Commerce, of Government, and of a University.-Lectures at the Lowell Institute.-Influence of oral Instruction in Literature and Science.-Fees of Public Lecturers. -Educational Funds sunk in costly Buildings.-Advantages of anti-building Clauses.-Blind Asylum.-Lowell Factories.-National Schools.-Equality of Sects.-Society in Boston.

October 7. 1841.-The steep slopes, as well as the summits of the ridges in the anthracite region of Pennsylvania, are so densely covered with wood, that the surveyors were obliged to climb to the of tops trees, in order to obtain general views of the country, and construct a geographical map on the scale of two inches to a mile, on which they laid down the result of their geological observations. Under the trees, the ground is covered with the Rhododendron, Kalmia and another evergreen called Sweet Fern (Comptonia asplenifolia), the leaves of which have a very agreeable odour, resembling that of our bog-myrtle (MyricaGale), but fainter. The leaves are so like those of a fern or Pteris in form, that the miners call the impressions of the fossil Pecopteris, in the coal-shales "sweet fern."

We found the German language chiefly spoken in this mountainous region, and preached in most of the churches, as at Reading. It is fast degenerating into a patois, and it is amusing to see many Germanized English words introduced even into the newspapers, 
such as turnpeik for turnpike, fense for fence, flauer for flour, or others, such as jail, which have been adopted without alteration.

From the Lehigh Summit Mine, we descended for nine miles on a railway impelled by our own weight, in a small car at the rate of twenty miles an hour. A man sat in front checking our speed by a drag on the steeper declivities, and oiling the wheels without stopping. The coal is let down by the same railroad, sixty mules being employed to draw up the empty cars every day. In the evening the mules themselves are sent down standing four abreast, and feeding out of mangers the whole way. We saw them start in a long train of waggons, and were told, that so completely do they acquire the notion that it is their business through life to pull weights up hill, and ride down at their ease, that if any of them are afterwards taken away from the mine and set to other occupations, they willingly drag heavy loads up steep ascents, but obstinately refuse to pull any vehicle down hill, coming to a dead halt at the commencement of the slightest slope.

The general effect of the long unbroken summits of the ridges of the Alleghany Mountains is very monotonous and unpicturesque: but the scenery is beautiful, where we meet occasionally with a transverse gorge through which a large river escapes. After visiting the Beaver Meadow coal field, we left the mountains by one of these openings, called the Lehigh Gap, wooded on both sides, and almost filled up by the Lehigh River, a branch of the Delaware, the banks of which we now followed to Trenton in New Jersey.

On our way, we heard much of a disastrous flood which occurred last spring on the melting of the snow, 
and swept away several bridges, causing the loss of many lives. I observed the trees on the right bank of the Delaware at an elevation of about twenty-four feet above the present surface of the river, with their bark worn through by the sheets of ice which had been driven against them. The canal was entirely filled up with gravel and large stones to the level of the towing path, twenty feet above the present level of the stream, which appeared to me to be only explicable by supposing the stones to have been frozen into and carried by the floating ice.

Oct. 11.-Reaching Trenton, the capital of New Jersey, late in the evening, we found the town in all the bustle of a general election. A new governor and representatives for the State legislature were to be chosen. As parties are nearly balanced, and the suffrage universal, the good order maintained was highly creditable. Processions, called "parades," were perambulating the streets headed by bands of music, and carrying transparencies with lights in them, in which the names of different counties, and mottoes, such as Union, Liberty, and Equality, were conspicuously inscribed. Occasionally a man called out with a stentorian voice, "The ticket, the whole ticket, and nothing but the ticket," which was followed by a loud English hurra, while at intervals a single blow was struck on a great drum, as if to imitate the firing of a gun. On their tickets were printed the names of the governor, officers, and members for whom the committee of each party had determined to vote.

The next day on our return to Philadelphia, we found that city also in the ferment of an election, bands of music being placed in open carriages, each drawn 
by four horses, and each horse decorated with a flag, attached to its shoulder, which has a gay effect. All day a great bell tolls at the State house, to remind the electors of their duties. It sounded like a funeral ; and on my inquiring of a bystander what it meant, one of the democratic party answered, "It is the knell of the whigs." In their popular addresses, some candidates ask the people whether they will vote for the whigs who will lay on new taxes. As it is well known, that such taxes must be imposed, if the dividends on the State bonds are to be paid, these popular appeals are ominous. The rapid fall in the value of State securities shows that the public generally have no confidence that the majority of the electors will be proof against the insidious arts of these demagogues.

Oct. 14.-We came from Philadelphia by New York to Boston, 300 miles, without fatigue in twentyfour hours, by railway and steam-boat, having spent three hours in an hotel at New York, and sleeping soundly for six hours in the cabin of a commodious steamer as we passed through Long Island Sound. The economy of time in travelling here is truly admirable. On getting out of the cars in the morning, we were ushered into a spacious saloon, where with 200 others we sat down to breakfast, and learnt with surprise, that, while thus agreeably employed, we had been carried rapidly in a large ferry-boat without perceiving any motion across a broad estuary to Providence in the State of Rhode Island.

Many trees in New Jersey, Connecticut, and Massachusetts, have now begun to assume their autumnal tints, especially the maples, while the oaks retain their vivid green colour. I can only compare the brightness 
of the faded leaves, scarlet, purple, and yellow, to that of tulips. It is now the Indian summer, a season of warm sunny weather, which often succeeds to the first. frost and rain, a time which the Indians employed in hunting and laying up a store of game for the winter.

Boston, Oct. 14. to Dec. 3. 1841.-It is fortunatithat Boston is at once a flourishing commercial port, and the seat of the best endowed university in America, for Cambridge, where Harvard College is situated, is so near, that it may be considered as a suburb of the metropolis. The medical lectures, indeed, are delivered in the city, where the great hospitals are at hand. The mingling of the professors, both literary and scientific, with the eminent lawyers, clergymen, physicians. and principal merchants of the place, forms a society of a superior kind ; and to these may be added severa persons, who, having inherited ample fortunes, hav successfully devoted their lives to original researches in history, and other departments. It is also a political advantage of no small moment that the legislature assembles here, as its members, consisting in great part of small proprietors farming their own land, are thus brought into contact with a community in a very advanced state of civilisation, so that they are under the immediate check of an enlightened public opinion. It is far more usual to place the capital, as it is called, in the centre of the State, often in some small village or town of no importance, and selected from mere geographical consideratians, which might well be disregarded in a country enjoying such locomotive facilities. An immense sacrifice is then required from those men of independent fortune, who, for patriotic motives, must leave the best society of a large city, to spend the win- 
ter in some remote spot in the discharge of public duties.

I had been invited when in England by Mr. Lowell, trustee and director of a richly endowed literary and scientific institution in this city, to deliver a course of twelve lectures on geology during the present autumn. According to the conditions of the bequest, the public have gratuitous admission to these lectures; but by several judicious restrictions, such as requiring applications for tickets to be made some weeks before, and compliance with other rules, the trustee has obviated much of the inconvenience arising from this privilege, for it is well known that a class which pays nothing is irregular and careless in its attendance. As the number of tickets granted for my lectures amounted to 4500 , and the class usually attending consisted of more than 3000 persons, it was necessary to divide them into two sets, and repeat to one of them the next afternoon the lecture delivered on the preceding evening. It is by no means uncommon for professors who have not the attraction of novelty, or the advantage which I happened to enjoy, of coming from a great distance, to command audiences in this institution as numerous as that above alluded to. The subjects of their discourses are various, such as natural history, chemistry, the fine arts, natural theology, and many others. Among my hearers were persons of both sexes, of every station in society, from the most affluent and eminent in the various learned professions to the humblest mechanics, all well dressed and observing the utmost decorum.

The theatres were never in high favour here, and most of them have been turned to various secular and ecclesiastical uses, and among others into lecture 
rooms, to which many of the public resort for amusement as they might formerly have done to a play, after the labours of the day are over. If the selection of teachers be in good hands, institutions of this kind cannot fail to exert a powerful influence in improving the taste and intellectual condition of the people, especially where college is quitted at an early age for the business of active life, and where there is always danger in a com* mercial community that the desire of money-making may be carried to excess. It is, moreover, peculiarly desirable in a democratic state, where the public mind is apt to be exclusively absorbed in politics, and in a country where the free competition of rival sects has a tendency to produce not indifferentism, as some at home may be disposed to think, but too much excitement in religious matters.

We are informed by Mr. Everett, late governor of Massachusetts (since minister of the U. S. in England), that before the existence of the Lowell Foundation, twenty-six courses of lectures were delivered in Boston, without including those which consisted of less than eight lectures, and these courses were attended in the aggregate by about 13,500 persons. But notwithstanding the popularity of this form of instruction, the means of the literary and scientific institutions of the city were wholly inadequate to hold out a liberal and certain reward to men of talent and learning. There were some few instances of continuous courses delivered by men of eminence; but the task more commonly devolved upon individuals who cultivated the art of speaking merely to become the vehicles of secondhand information, and who were not entitled to speak 
with authority, and from the fulness of their own knowledge.*

The rich who have had a liberal education, who know how to select the best books, and can afford to purchase them, who can retreat into the quiet of their libraries from the noise of their children, and, if they please, obtain the aid of private tuition, may doubt the utility of public lectures on the fine arts, history, and the physical sciences. But oral instruction is, in fact, the only means by which the great mass of the middling and lower classes can have their thoughts turned to these subjects, and it is the fault of the higher classes if the information they receive be unsound, and if the business of the teacher be not held in high honour. The whole body of the clergy in every country, and, under popular forms of government, the leading politicians, have been in all ages convinced that they must avail themselves of this method of teaching, if they would influence both high and low. No theological dogma is so abstruse, no doctrine of political economy or legislative science so difficult, as to be deemed unfit to be preached from the pulpit, or inculcated on the hustings. The invention of printing, followed by the rapid and general dispersion of the cheap daily newspaper, or the religious tract, have been by no means permitted to supersede the instrumentality of oral teaching, and the powerful sympathy and excitement created by congregated numbers. If the leading patrons and cultivators of literature and physical science neglect this ready and efficacious means of interesting the multitude in their pursuits, they are wanting to

* See " Everett's Memoir of John Lowell." Boston, 1840. 
themselves, and have no right to complain of the apathy or indifference of the public.

To obtain the services of eminent men engaged in original researches, for the delivery of systematic courses of lectures, is impossible without the command of much larger funds than are usually devoted to this object. When it is stated that the fees at the Lowell Institute at Boston are on a scale more than three times higher than the remuneration awarded to the best literary and scientific public lecturers in London, it will at first be thought hopeless to endeavour to carry similar plans into execution in other large cities, whether at home or in the United States. In reality, however, the sum bequeathed by the late Mr. John Lowell for his foundation, though munificent, was by no means enormous, not much exceeding $70,000 l$., which, according to the usual fate awaiting donations for educational objects, would have been all swallowed up in the erection of costly buildings, after which the learned would be invited to share the scanty leavings of the "Committee of Taste," and the merciless architect, "reliquias Danaûm atque immitis Achillei." But in the present case, the testator provided in his will that not a single dollar should be spent in brick and mortar, in consequence of which proviso, a spacious room was

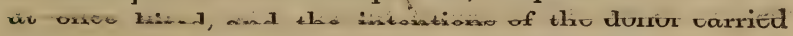
immediately into effect, without a year's delay.

If there be any who imagine that a donation might be so splendid as to render an anti-building clause superfluous, let them remember the history of the Girard bequest in Philadelphia. Half a million sterling, with the express desire of the testator that the expenditure on architectural ornament should be moderate! Yet 
this vast sum is so nearly consumed, that it is doubtful whether the remaining funds will suffice for the completion of the palace-splendid, indeed, but extremely ill-fitted for a school-house ! It is evident that when a passion so strong as that for building is to be resisted, total abstinence alone, as in the case of spirituous liquors, will prove an adequate safeguard. In the "old country," the same fatal propensity has stood in the way of all the most spirited efforts of modern times to establish and endow new institutions for the diffusion of knowledge. It is well known that the sum expended in the purchase of the ground, and in the erection of that part of University College, London, the exterior of which is nearly complete, exceeded $100,000 l$., one-third of which was spent on the portico and dome, or the purely ornamental, the rooms under the dome having remained useless, and not even fitted up at the expiration of fifteen years. When the professor of chemistry enquired for the chimney of his laboratory, he was informed that there was none, and to remove the defect, a flue was run up which encroached on a handsome staircase, and destroyed the symmetry of the architect's design. Still greater was the dismay of the anatomical professor on learning that his lecture room was to conform to the classical model of an ancient theatre, desioned for the recitation of Greek plays. Sir Charles Bell remarked that an anatomical theatre, to be perfect, should approach as nearly as possible to the shape of a well, that every student might look down and see distinctly the subject under demonstration. At a considerable cost the room was altered, so as to serve the ends for which it was wanted.

The liberal sums contributed by the public for the 
foundation of a rival college were expended in like manner long before the academical body came into existence. When the professor of chemistry at King's College asked for his laboratory, he was told it had been entirely forgotten in the plan, but that he might take the kitchen on the floor below, and by ingenious machinery carry up his apparatus for illustrating experiments, through a trap door into an upper story, where his lecture room was placed.

Still these collegiate buildings, in support of which the public came forward so liberally, were left, like the Girard College, half finished; whereas, if the same funds had been devoted to the securing of teachers of high acquirements, station, character, and celebrity; and if rooms of moderate dimensions had been at first hired, while the classes of pupils remained small, a generation would not have been lost, the new Institutions would have risen more rapidly to that high rank which they are one day destined to attain, and testamentary bequests would have flowed in more copiously for buildings well adapted to the known and ascertained wants of the establishment. None would then grudge the fluted column, the swelling dome, and the stately portico; and literature and science would continue to be the patrons of architesture; without being its victims.

Prescott, in his admirable work on the Conquest of Mexico, remarks, when discussing the extent of the ancient Aztec civilisation, that the progress made by the Irexicans in astronomy, and especially the fact of their having a general board for public education and the fine arts, proves more in favour of their advancement, than the noble architectural monuments which 
they and their kindred tribes erected. "Architecture," he observes, "is a sensual gratification, and addresses itself to the eye ; it is the form in which the resources of a semi-civilised people are most likely to be lavished."*

Mr. John Lowell, a native of Massachusetts, after having carefully studied the educational establishments of his own country, visited London in 1833, and having sojourned there some months, paying a visit to the University of Cambridge and other places, he pursued his travels in the hope of exploring India and China. On his way he passed through Egypt, where, being attacked, while engaged in making a collection of antiquities, by an intermittent fever, of which he soon afterwards died, he drew up his last will in 1835, amidst the ruins of Thebes, leaving half of his noble fortune for the foundation of a Literary Institute in his native city. It has already appeared how admirably he appreciated the exact point of "semi-civilisation" which the Anglo-Saxon race had then attained on both sides of the Atlantic.

I spent an agreeable day at Cambridge, visiting several of the professors at Harvard University, and hearing one of them, Henry Ware, author of "The Christian Character," a work reprinted, and much read in England, preach a sormun in the College Chapel. His text, "Thou shalt love thy neighbour as thyself," led him to treat of self-love, and to explain how this natural passion might be indulged to any extent, provided, in obedience to the divine commandment, our love for others increases in the like ratio. I heard afterwards, with great regret, of the death of this able and amiable man. In the Blind Asylum I saw Laura Bridgman, now

* Conquest of Mexico, vol. i. p. 155. 
in her twelfth year. At the age of two she lost her sight and hearing by a severe illness, but although deaf, dumb, and blind, her mind has been so advanced by the method of instruction pursued by Dr. Howe, that she shows more intelligence and quickness of feeling than many girls of the same age who are in full possession of all their senses. The excellent reports of Dr. Howe, on the gradual development of her mind, have been long before the public, and have recently been cited by Mr. Dickens, together with some judicious observations of his own. Perhaps no one of the cases of a somewhat analogous nature, on which Dugald Stewart and others have philosophised, has furnished so many new and valuable facts illustrating the extent to which all intellectual development is dependent on the instrumentality of the senses in discerning external objects, and, at the same time, in how small a degree the relative acuteness of the organs of sense determine the moral and intellectual superiority of the individual. Nov. 15.-Went twenty-six miles to the north of Boston, by an excellent railway, to the manufacturing town of Lowell, which has sprung up entirely in the last sixteen years, and now. contains about 20,000 inhabitants. The mills are remarkably clean, and well warmed, and almost all for making cotton and woollen goods, which are exported to the West. The young women from the age of eighteen to twenty-five, who attend to the spinning-wheels, are good-looking and neatly dressed, chiefly the daughters of New England farmers, sometimes of the poorer clergy. They belong, therefore, to a very different class from our manufacturing population, and after remaining a few years in the factory, return to their homes, and usually marry. 
We are told that, to work in these factories is considered far more eligible for a young woman than domestic service, as they can save more, and have stated hours of work (twelve hours a day!), after which they are at liberty. Their moral character stands very high, and a girl is paid off, if the least doubt exists on that point. Boarding-houses, usually kept by widows, are attached to each mill, in which the operatives are required to board; the men and women being separate. This regard for the welfare and conduct of the workpeople when they are not on actual duty is comparatively rare in England, where the greater supply of labour would render such interference and kind superintendence much more practicable. Still we could not expect that the results would be equally satisfactory with us, on account of the lower grade of the operatives, and the ignorance of the lower classes in England. In regard to the order, dress, and cleanliness of the people, these merits are also exemplified in the rural districts of Lancashire, and it is usually in our large towns alone, that the work people are unhealthy and squalid, especially where a number of the poor Irish live crowded together in bad dwellings.

The factories at Lowell are not only on a great scale, but have been so managed as to yield high profits, a fact which should be impressed on the mind of every foreigner who visits them, lest, after admiring the gentility of manner and dress of the women and men employed, he should go away with the idea that he had been seeing a model mill, or a set of gentlemen and ladies, playing at factory for their amusement. There are few children employed, and those under fifteen are compelled by law to go to school three months in the 
year, under penalty of a heavy fine. If this regulation is infringed, informers are not wanting, for there is a strong sympathy in the public mind with all acts of the legislature, enforcing education. The Bostonians submit to pay annually for public instruction in their city alone, the sum of $30,000 l$. sterling, which is about equal to the parliamentary grant of this year (1841) for the whole of England, while the sum raised for free schools in the state this year, by taxes for wages of teachers, and their board, and exclusive of funds for building, exceeds $100,000 l$. sterling.

The law ordains, that every district containing fifty families shall maintain one school, for the support of which the inhabitants are required to tax themselves, and to appoint committees annually for managing the funds, and choosing their own schoolmasters. The Bible is allowed to be read in all, and is actually read in nearly all the schools; but the law prohibits the use of books "calculated to favour the tenets of any particular sect of Christians." Parents and guardians are expected to teach their own children, or to procure them to be taught, what they believe to be religious truth, and for this purpose, besides family worship and the pulpit, there are Sunday-schools. The system works well among this church-building and churchgoing population.

As there is no other region in Anglo-saxondom, containing 750,000 souls, where national education has been carried so far, it is important to enquire to what combination of causes its success is mainly to be attributed. First, there is no class in want or extreme poverty here, partly because the facility of migrating to the west, for those who are without employment, is so 
great, and also, in part, from the check to improvident marriages, created by the high standard of living to which the lowest work-people aspire, a standard which education is raising higher and higher from day to day. Secondly, I have often heard politicians of opposite parties declare, that there is no safety for the republic, now that the electoral suffiage has been so much extended, unless every exertion is made to raise the moral and intellectual condition of the masses. The fears entertained by the rich of the dangers of ignorance, is the only good result which I could discover tending to counterbalance the enormous preponderance of evil arising in the United States from so near an approach to universal suffrage. Thirdly, the political and social equality of all religious sects, - a blessing which the New Englanders do not owe to the American revolution, for it was fully recognised and enjoyed under the supremacy of the British crown. This equality tends to remove the greatest stumbling block, still standing in the way of national instruction in Great Britain, where we allow one generation after another of the lower classes to grow up without being taught good morals, good behaviour, and the knowledge of things useful and ornamental, because we cannot all agree as to the precise theological doctrines in which they are to be brought up. The religious toleration of the different sects towards each other in Massachusetts is, I fear, accompanied by as little Christian charity as at home, and families are often divided, and the best relations of private life disturbed, by the bitterness of sectarian dogmatism and jealousy; but, politically, all sects are ready to unite against the encroachments of any other, and a great degree of religious freedom 
is enjoyed, in consequence of there being no sect to which it is ungenteel to belong, no consciences sorely tempted by ambition to conform to a more fashionable creed.

In New York the Roman Catholic priests have recently agitated with no small success for a separate allotment of their share of the education fund. They have allied themselves, as in the Belgian revolution, with the extreme democracy to carry their point, and may materially retard the general progress of education. But there is no reason to apprehend that any one sect in New England will have power to play the same game; and these states are the chief colonizers of the West-gentis cunabula, by the rapidity of whose multiplication and progress in civilization the future prospects of the whole confederacy of republics will be mainly determined.

During our stay at Boston the citizens gave a splendid ball to the Prince de Joinville, and the Mayor politely sent us tickets of invitation, which gave me an opportunity of satisfying myself that foreigners have not said too much of the beauty of the young American ladies. In general I was so much occupied with my lectures, or in communicating to the Geological Society of London some of the results of my observations during my late tour, that I had no time to enter into society, or to accept the hospitalities of the inhabitants. As soon as it was understood that I wished to live quietly, all pressing invitations were politely abstained from until I had finished my course of lectures; and, afterwards, when $I$ found it necessary to decline a large number of them, no offence was taken.

The twenty-fifth of November was appointed by the 
Governor of the State to be what is here called Thanksgiving-Day - an institution as old as the times of the Pilgrim Fathers, one day in the year being set apart for thanksgiving for the mercies of the past year. As a festival it stands very much in the place of Christmas Day as kept in England and Germany, being always in the winter, and every body going to church in the morning and meeting in large family parties in the evening. To one of these we were most kindly welcomed; and the reception which we met with here and in the few fanilies to which we had letters of introduction, made us entirely forget that we were foreigners. Several of our new acquaintances indeed had travelled in England and on the Continent, and were in constant correspondence with our own literary and scientiffc friends, so that we were always hearing from them some personal news of those with whom we were most intimate in Europe, and we often reflected with surprise in how many parts of England we should have felt less at home.

I remember an eminent English writer once saying to me, when he had just read a recently-published book on the United States, "I wonder the author went so far to see disagreeable people, when there are so many of them at home." It would certainly be strange if persons of refined habits, even without being fastidious, who travel to see life, and think it their duty, with a view of studying character, to associate indiscriminately with all kinds of people, visiting the first strangers who ask them to their houses, and choosing their companions without reference to congeniality of taste, pursuits, manners, or opinions, did not find society in their own or any other country in the world intolerable. 


\section{CHAPTER VI.}

Fall of Snow and Sleigh-driving at Boston.-Journey to New Haven.-Ichthyolites of Durham, Connecticut.-Age of Red Sandstone.-Income of Farmers.-Baltimore.-Washington.-National Museum.-Natural Impediments to the Growth of Washington.Why chosen for the Capital.-Richmond, Virginia._Effects of Slave-labour.-Low Region on the Allantic Border, occupied by Tertiary Strata.-Infusorial Bed at Richmond.-Miocene Shells and Corals in the Cliffs of the James River compared with Fossils of the European Crag and Faluns.-Analogy of Forms and Difference of Species.-Proportion of Species-Commencement of the present Geographical Distribution of Mollusca.

Nov. 29. 1841.-Aцтнолgh we were in the latitude of Rome, and there were no mountains near us, we had a heavy fall of snow at Boston this day, followed by bright sunshine and hard frost. It was a cheerful scene to see the sleighs gliding noiselessly about the streets, and to hear the bells, tied to the horses' heads, warning the passer-by of their swift approach. As it was now the best season to geologise in the southern States, I determined to make a flight in that direction; and we had gone no farther than New Haven before we found that all the snow had disappeared. I accordingly took the opportunity when there of making a geological excursion, with Mr. Silliman, jun., Professor Hubbard, and Mr. Whelpley, to examine the red sandstone strata, containing Ichthyolites, by the side of a small waterfall at Middlefield, one mile from Durham, in Connecticut. The remains of fish occur in a finegrained slaty sandstone, black and bituminous, about six feet thick, which alternates with a coarse conglom- 
erate, some of the quartz pebbles being two or three inches in diameter. Small fragments of fossil wood and a ripple-marked surface were observed in some of the strata near the fossil-fish. This sandstone is newer than the coal, but we have not yet sufficient data to pronounce very decidedly on its true age. The footsteps of numerous species of birds afford no indication, because in Europe we have as yet no traces of birds in rocks of such high antiquity, and consequently no corresponding term of comparison. As to the fish, they have most of them been referred to the genus Paleoniscus, and have been supposed, therefore, by analogy, to imply that the Connecticut deposit is of the age of the Magnesian limestone(Lower New Red or Permian Group of Europe). But Mr. Redfield has expressed some doubt whether these American fossils might not constitute a new, though allied genus, having the scales, and apparently the vertebræ, prolonged to a more limited extent into the upper lobe of the tail than in the European species. In the language of $M$. Agassiz, they are less heterocercal than the European Paleoniscus, and, therefore, less closely related to that type which is universal in the more ancient or paleozoic formations. Sir P. Egerton, who confirms these reznarks of Mr. Redfield, and adds other distinctions, such as the strong and conical teeth, and the smallness of the oral aperture, informs me that in the five or six distinct species obtained by me from Durham, Connecticut, he finds the scales to be smoother than in the Paleonisci of the Magnesian limestone; for the latter have their scales more or less striated and serrated on the posterior margins. The American fossils approximate in the character above alluded to, or in having 
smooth scales, to the coal-measure species, so that the evidence derived ftom Ichthyology is very conflicting. Professor H. D. Rogers infers from his brother's discovery in Virginia of shells in this formation, referred to the Posidonia Keuperi, a characteristic species of the European Trias, that the Connecticut sandstone belongs to the Upper New Red or Triassic system.

In the neighbourhood of Durham we learnt that a snow-storm, which occurred there in the first week of October, had seriously injured the woods, weighing down the boughs then in full leaf, and snapping off the leading shoots. For the first time in the United States I heard great concern expressed for the damage sustained by the timber, which is beginning to grow scarce in New England, where coal is dear.

The valley of the Connecticut presents a pleasing picture of a rural population, where there is neither poverty nor great wealth. I was told by well-informed persons, that if the land and stock of the farmers or small proprietors were sold off and invested in securities giving six per cent. interest, their average incomes would not exceed more than from $80 l$. to $120 l$. a year. An old gentleman who lately re-visited Durham, his native place, after an absence of twenty-five years, told me that in this interval the large families, the equal subdivision of the paternal estates among children, and the efforts made for the outfit of sons migrating to the West, had sensibly lowered the fortunes of the Connecticut yeomanry, so that they were reduced nearer to the condition of labourers than when he left them.

Pursuing my course southwards, I found that the snow-storm had been less heavy at New York, still less at Philadelphia, and after crossing the Susquehanna 
(Dec. 13.) the weather began to resemble that of an English spring. In the suburbs of Baltimore, the locomotive engines being detached, our cars were drawn by horses on a railway into the middle of the town. Maryland was the first slave state we had visited; and at Baltimore we were reminded for the first time of the poorer inhabitants of a large European city by the mean dwellings and dress of some of the labouring class, both coloured and white.

At Washington I was shown the newly-founded national museum, in which the objects of natural history and other treasures collected during the late voyage of discovery to the Antarctic regions, the South Seas, and California, are deposited. Such a national repository would be invaluable at Philadelphia, New York, or Boston, but here there is no university, no classes of students in science or literature, no philosophical societies, no people who seem to have any leisure. The members of Congress rarely have town residences in this place, but, leaving their families in large cities, where they may enjoy more refined society, they live here in boarding-houses until their political duties and the session are over. If the most eminent legislators and statesmen, the lawyers of the supreme courts, and the foreign ambassadors, had all been assembled here for a great part of the year with their families, in a wealthy and flourishing metropolis, the social and political results of a great centre of influence and authority could not have failed to be most beneficial. Circumstances purely accidental, and not the intentional jealousy of the democracy, have checked the growth of the capital, and deprived it of the constitutional ascendency which it might otherwise have exerted. Con- 
Chap. vi. WASHINGTON, Why THE CAPITAL. 103

gress first assembled in Philadelphia, where the declaration of independence was signed; but after the close of the revolutionary war in June, 1783, a party of the disbanded army marched to that city to demand their arrears of pay, and surrounded the building in which the representatives of the people were sitting, with fixed bayonets for about three hours. This alarm caused them to adjourn and meet at Princeton, New Jersey, and afterwards to seek some permanent seat of government. But for this untoward event, Philadelphia might have remained the federal metropolis, and in that case would certainly have lifted up her head above other cities in the New World-

"Quantùm lenta solent inter viburna cupressi."

General Washington is said to have selected the present site of the capital as the most central spot on the Atlantic border, being midway between Maine and Florida, and being also at the head of the navigation of a great river. He had observed that all the other principal cities eastward of the Alleghany mountains had sprung up on similar sites; but unfortunately the estuary of the Potomac is so long and winding, that to ascend from its mouth to Washington is said often to take a vessel as long as to cross from Liverpool to the mouth of the river. Had Annapolis, which is only thirty miles distant, been chosen as the capital, it is believed that it would, ere this, have contained 100,000 inhabitants.

We were present at an animated debate in the House of Representatives, on the proposed protective tariff, and a discussion in the senate on "Ways and Means," both carried on with great order and decorum. After being presented to the President, and visiting 
several persons to whom we had letters, we were warned by a slight sprinkling of snow that it was time to depart and migrate further southwards. Crossing the Potomac, therefore, I proceeded to Richmond, in Virginia, where I resolved to sail down the James River, in order to examine the geology of the tertiary strata on its shores.

On entering the station-house of a railway which was to carry us to our place of embarkation, we found a room with only two chairs in it. One of these was occupied by a respectable-looking woman, who immediately rose, intending to give it up to me, an act betraying that she was English, and newly-arrived, as an American gentleman, even if already seated, would have felt it necessary to rise and offer the chair to any woman, whether mistress or maid, and she, as a matter of course, would have accepted the proffered seat. After I had gone out, she told my wife that she and her husband had come a few rnonths before from Hertfordshire, hoping to get work in Virginia, but she had discovered that there was no room here for poor white people, who were despised by the very negroes if they laboured with their own hands. She had found herself looked down upon, even for carrying her own child, for they said she ought to hire a black nurse. These poor emigrants were now anxious to settle in some free state.

As another exemplification of the impediments to improvement existing here, I was told that a New England agriculturist had bought a farm on the south side of the James river, sold off all the slaves, and introduced Irish labourers, being persuaded that their services would prove more economical than slave-labour. 
The scheme was answering well, till, by the end of the third year, the Irish became very much dissatisfied with their position, feeling degraded by losing the respect of the whites, and being exposed to the contempt of the surrounding negroes. They had, in fact, lowered themselves by the habitual performance of offices which, south of the Potomac, are assigned to hereditary bondsmen.

\section{Miocene Tertiary Strata of Virginia.}

We have already seen that between the hilly country and the Atlantic there occurs in the United States, a low and nearly level region (A, B, fig. 5, p. 74.), occupied principally by beds of marl, clay, and sand of the cretaceous and tertiary formations. Maclure, in 1817, in his work on geology, laid down with no small accuracy on a coloured map the general limits of this great plain, and of the granitic district lying immediately to the westward. He also pointed out that at the junction of these great geological provinces $(\mathrm{A}, \mathrm{B}$, and $\mathrm{B}, \mathrm{C}$, fig. 5.), at the point $h$, as indicated in the section, almost all the great rivers descend suddenly by falls or rapids of moderate height, as the Delaware at Trenton, the Schuylkill near Philadelphia, the Potomac near Washington, the James river at Richmond, Virginia, the Savannah at Augusta in Georgia, and many others. At these points, therefore, the navigation is stopped, and a great many large cities have sprung up precisely. at this limit, so that the line which marks the western boundary of the tertiary, and the eastern of the granitic region, is one of no small geological, geographical, and political interest. 
The general elevation of the great plain does not exceed a hundred feet, although sometimes considerably higher. Its width in the middle and southern states is very commonly from 100 to 150 miles. The tide, except in the more southern states, flows entirely across it, and the rivers intersecting it form large estuaries, which may have been due to the facility with which the incoherent materials of the cliffs were undermined and swept away, a process of waste which is still going on.

Throughout the greater part of the Atlantic plain, the cretaceous rocks, if present, are concealed by the overlying tertiary deposits, which consist chiefly of Miocene strata, extending from Delaware bay to the Cape Fear river, and occupying portions of Delaware, Maryland, Virginia, and North Carolina, an area about 400 miles long from north to south, and varying in breadth from 10 to 70 miles. There are, besides, some patches of the Miocene formation in South Carolina and Georgia, where the Eocene or older tertiary deposits predominate almost exclusively.

I began my examination of these tertiary strata in the suburbs of Richmond, Virginia, where I saw in Shockoe creek some Eocene marls with characteristic shells, on which reposed Miocene red clay and sand. Between the two formations a remarkable bed of yellow siliceous clay intervenes, from twelve to twentyfive feet thick, marked on the surface by a band of meagre vegetation. This clay was found by Professor W. B. Rogers to be entirely composed of the siliceous cases of Infusoriæ, so minute as only to be detected by a powerful microscope, and yet exhibiting distinct spe- 
cific characters, enabling us to refer them to the Miocene period.

Going down the James river about twenty miles below Richmond, I found, at a place called City Point, on the right bank, a cliff thirty feet high, in which yellow and white sands appear, with shells very analogous to those of the Suffolk crag, and referable to the same age ; resting on Eocene marl and green earth. Several miles lower, at Evergreen, I collected abundance of shells in the upper or Miocene formation, with great numbers of an Astarte, resembling one of the commonest kinds of the Suffolk crag, and accompanied by the teeth of sharks, and bones of cetacea. Landing then at Coggin's Point, several miles farther eastward on the Virginian shore, I was conducted by Mr. Ruffin, son of the editor of the Farmer's Register, to a locality where shell-marl is procured and used for improving light soils, just as in Suffolk and on the Loire, strata of the same age, called crag and falun, have for centuries afforded a fertilizing mixture.

Here, and at Evergreen before mentioned, large flattened masses several feet wide, of a lamelliform coral resembling an Astraca, were lying on the beach, washed out of the Miocene marls. The species has been called by Mr. Lonsdale Columnaria sexradiata, and differs from the genus Astræa, as defined by Ehrenberg, in the stars not being subdivided.

All the planters in this part of Virginia, to whose houses I went without letters of introduction, received me most politely and hospitably. To be an Englishman engaged in scientific pursuits was a sufficient passport, and their servants, horses, and carriages, were most liberally placed at my disposal. 
I then crossed to the north side of the James river, being rowed out at sunrise far from the shore to wait for a steamer. The hour of her arrival being somewhat uncertain, we remained for some time in the cold, muffled up in our cloaks, in a small boat moored to a single wooden pile driven into a shoal, with three negroes for our companions. The situation was desolate in the extreme, both the banks of the broad estuary appearing low and distant, and as wild and uninhabited as when first discovered in 1607, by Captain Smith, before he was taken prisoner, and his life saved by the Indian maiden Pocahontas. At length we gladly hailed the large steamer as she came down rapidly towards us, and my luggage was immediately taken charge of by two of the sable crew, who called themselves Lord Wellington and Julius Cæsar.

We disembarked in a few hours near the old deserted village of Jamestown, at the Grove Landing; seven miles south of Williamsburg. Here I found the beach strewed over with innumerable fossil shells, washed out of the sandy Miocene marls of a cliff forty feet high. Some large varieties of the genus Pecten were most abundant, closely packed together in a dense bed, above which was another layer composed almost wholly of the shells of a Chama (C. congregata), both valves being united in each individual. From the same cliff I also procured shells of the genera Conus, Oliva, Marginella, Fusus, Pyrula, Murex, Natica, and others.

We then visited Williamsburg, where there is a University founded by William and Mary, and therefore very ancient for this country. In the neighbourhood I procured a rich harvest of fossil shells, collecting in one 
morning with my own hands no less than seventy distinct species, besides several corals, in a pit at Burwell's Mill. Upon the whole, I procured 147 species of shells, exclusive of Balani and corals, from this formation in the United States, and chiefly during the present expedition and near the banks of the James river.

That they belong to the same age as the Miocene deposits of Europe may be inferred:- first, from their position, as they overlie the Eocene marls containing shells, resembling those of the London and Paris basins :- secondly, from the close affinity of many of the most abundant species to fossils of the crag of Suffolk and the French faluns:- thirdly, from the proportion of the fossil shells, identical in species with mollusca, now inhabiting the American coast, the proportion being about one sixth of the whole, or about seventeen per cent., in those compared by me, for I have been able to identify 23 out of 147 with living shells. This relation of the fossil and recent fauna had already led Mr. Conrad and the Professors Rogers to the same conclusions, and they had correctly called these deposits Miocene. Fourthly, the corals, of which I obtained thirteen species, agree all generizally with those of the Miocene beds of Europe, and some specifically, as a lunulite, the same as one from the Suffolk crag, and Anthophyllum breve, common in the faluns of Touraine. Fifthly, the cetacea also agree generically, and the fish in many cases specifically, with European Miocene fossils, and no remains of reptiles have been found on either side of the Atlantic in this formation.

When we consider how remarkably the species of the Suffolk crag differ from the shells of the contemporaneous faluns of the Loire, the geologist will not be 
surprised to learn that I have only met with nine American Miocene shells, agreeing with fossils of the same period in Europe. It is also worthy of notice that the shells identified with recent species agree with testacea, now living on the western side of the Atlantic, some of which, as some kinds of Fulgur, a subgenus of Pyrula, and Gnathodon, an estuary shell, are forms peculiar to America. In like manner, the fossil shells found in the Miocene strata of Europe, which agree with recent kinds, belong to species inhabiting the British seas, the Mediterranean, or the African coast of the Atlantic. Hence it follows that at the remote period called Miocene, the seas were not only divided as now into distinct geographical provinces, but already that peculiar distribution of the living mollusca which now exists had begun to prevail. This conclusion is remarkable when we recollect that at the geological era alluded to, the fauna was so distinct from the present, that four fifths of the species now living had not yet come into existence.

In regard to the climate of the Miocene period it is not uninteresting to observe that the fossil shells of Maryland and Virginia resemble those of Touraine and Bourdeaux more nearly than the fossils of Suffolk. This might have been expected from the nearer correspondence in latitude; and it is the presence of such genera as Conus, Oliva, Marginella, and Crassatella (represented by large species), forms belonging to warmer seas, which assimilate the American and French deposits, and contrast both of them with the English, where no representatives of these genera are met with. Nevertheless, it is singular that there should be so much resemblance between the Miocene shells of 
the Loire and Gironde and those of the James river and other estuaries in the United States which lie ten degrees of latitude farther south than the French faluns, the latter being in the $47 \mathrm{th}$, while the American strata of the same age are in the 37 th of north latitude. This circumstance may probably be accounted for by curves in the-isothermal lines similar in their prolongation east and west, to those now existing as pointed out by Humboldt, in his essay on Climate. 


\section{CHAPTER VII.}

Pine Barrens of Virginia and North Carolina,-Railway Train stopped by Snow and Ice.-The Great Dismal Swamp.-Soil formed entirely of Vegetable Matter.-Rises higher than the contiguous firm Land.-Buried Timber.-Lake in the Middle.-The Origin of Coal illustrated by the Great Dismal.-Objections to the Theory of an ancient Atmosphere highly charged with Carbonic Acid.

Dec. 23. 1841.-From Williamsburg we went to Norfolk in Virginia, passing down the James river in a steamer, and from Norfolk by railway to Weldon in North Carolina, passing for eighty miles through a low level country, covered with fir trees, and called the Pine Barrens. On our way we were overtaken by rain, which turned to sleet, and in the evening formed a coating of ice on the rails, so that the wheels of the engine could take no hold. There was a good stove and plenty of fuel in the car, but no food. After a short pause, the engineer backed the locomotive for half a mile over that part of the rail from which the snow and ice had just been brushed and scraped away by the passage of the train; then, returning rapidly, he gained sufficient momentum to carry us on two or three miles farther, and, by several repetitions of this manœuvre, he brought us, about nightfall, to a small watering station, where there was no inn, but a two-storied cottage not far off.

Here we were made welcome, and as we had previously dropped by the way all our passengers except two, were furnished with a small room to ourselves, and a 
clean comfortable bed. We soon made a blazing woodfire, and defied the cold, although we could see plainly the white snow on the ground through openings in the unplastered laths of which the wall of the house was made. Before morning all the snow was melted, and we again proceeded on our way through the Pine Barrens.

Our car, according to the usual construction in this country, was in the shape of a long omnibus, with the seats transverse, and a passage down the middle, where, to the great relief of the traveller, he can stand upright with his hat on, and walk about, warming himself when he pleases at the stove, which is in the centre of the car. There is often a private room fitted up for the ladies, into which no gentleman can intrude, and where they are sometimes supplied with rocking-chairs, so essential to the comfort of the Americans, whether at sea or on land, in a fashionable drawing-room or in the cabin of a ship. It is singular enough that this luxury, after being popular for ages all over Lancashire, required transplantation to the New World before it could be improved and become fashionable, so as to be reimported into its native land.

The Pine Barrens, on which the long-leafed or pitch pines flourish, have for the most part a siliceous soil, and form a broad belt many hundred miles in length, running parallel to the coast, in the region called the Atlantic Plain, before alluded to. The sands, as we follow this region from New Jersey to Georgia, are derived from strata of more than one tertiary period, and there are interstratified beds of clay, which, whenever they come to the surface in valleys, cause swamps, where peculiar kinds of evergreen oaks, the cypress or 
cedar, tall canes, and other plants abound. Many climbers, called here wild vines, encircle the trunks of the trees, and on the banks of the Roanoke, near Weldon, I saw numerous missletoes with their white berries. The Pine Barrens retain much of their verdure in winter, and were interesting to me from the uniformity and monotony of their general aspect, for they constitute, from their vast extent, one of the marked features in the geography of the globe, like the Pampas of South America.

There are many swamps or morasses in this low flat region, and one of the largest of these occurs between the towns of Norfolk and Weldon. We traversed several miles of its northern extremity on the railway, which is supported on piles. It bears the appropriate and very expressive name of the "Great Dismal," and is no less than forty miles in length from north to south, and twenty-five miles in its greatest width from east to west, the northern half being situated in Virginia, the southern in North Carolina. I observed that the water was obviously in motion in several places, and the morass has somewhat the appearance of a broad inundated river-plain, covered with all kinds of aquatic trees and shrubs, the soil being as black as in a peat-bog. The accumulation of vegetable matter going on here in a hot climate, over so vast an area, is a subject of such high geological interest, that I shall relate what I learnt of this singular morass. The best account yet published of it is given by Mr. Edmund Ruffin, the able editor of the Farmer's Register (see vol iv., No. 9. January 7. 1837).

It is one enormous quagmire, soft and muddy, except where the surface is rendered partially firm by a cover- 
ing of vegetables and their matted roots; yet, strange to say, instead of being lower than the level of the surrounding country, it is actually higher than nearly all the firm and dry land which encompasses it, and, to make the anomaly complete, in spite of its semi-fluid character, it is higher in the interior than towards its margin.

The only exceptions to both these statements is found on the western side, where, for the distance of about twelve or fifteen miles, the streams flow from slightly elevated but higher land, and supply all its abundant and overflowing water. Towards the north, the east, and the south, the waters flow from the swamp to different rivers, which give abundant evidence, by the rate of their descent, that the Great Dismal is higher than the surrounding firm ground. This fact is also confirmed by the measurements made in levelling for the railway from Portsmouth to Suffolk, and for two canals cut through different parts of the morass, for the sake of obtaining timber. The railway itself, when traversing the Great Dismal, is literally higher than when on the land some miles distant on either side, and is six to seven feet higher than where it passes over dry ground, near to Suffolk and Portsmouth. Upon the whole, the centre of the morass seems to lie more than twelve feet above the flat country round it. If the streams which now flow in from the west, had for ages been bringing down black fluid mire, instead of water, over the firm subsoil, we might suppose the ground so inundated to have acquired its present configuration. Some small ridges, however, of land must have existed in the original plain or basin, for these now rise like low islands in various places above the general surface. 
But the streams to the westward do not bring down liquid mire, and are not charged with any sediment. The soil of the swamp is formed of vegetable matter, usually without any admixture of earthy particles. We have here, in fact, a deposit of peat from ten to fifteen feet in thickness, in a latitude where, owing to the heat of the sun, and length of the summer, no peat mosses like those of Europe would be looked for under ordinary circumstances.

In countries like Scotland and Ireland, where the climate is damp, and the summer short and cool, the natural vegetation of one year does not rot away during the next in moist situations. If water flows into such land, it is absorbed, and promotes the vigorous growth of mosses and other aquatic plants, and when they die, the same water arrests their putrefaction. But as a general rule, no such accumulation of peat can take place in a country like that of Virginia, where the summer's heat causes annually as large a quantity of dead plants to decay as is equal in amount to the vegetable matter produced in one year.

It has been already stated that there are many trees and shrubs in the region of the Pine Barrens (and the same may be said of the United States generally), which, like our willows, flourish luxuriantly in water. The juniper trees, or white cedar (Cupressus thyoides), stand firmly in the softest part of the quagmire, supported by their long tap-roots, and afford, with many other evergreens, a dark shade, under which a multitude of ferns, reeds, and shrubs, from nine to eighteen feet high, and a thick carpet of mosses, four or five inches high, spring up and are protected from the rays of the sun. When these are most 
powerful, the large cedar (Cupressus disticha) and many other deciduous trees are in full leaf. The black soil formed beneath this shade, to which the mosses and the leaves make annual additions, does not perfectly resemble the peat of Europe, most of the plants being so decayed as to leave little more than soft black mud, without any traces of organization. This loose soil is called sponge by the labourers; and it has been ascertained that, when exposed to the sun, and thrown out on the bank of a canal, where clearings have been made, it rots entirely away. Hence it is evident that it owes its preservation in the swamp to moisture and the shade of the dense foliage. The evaporation continually going on in the wet spongy soil during summer cools the air, and generates a temperature resembling that of a more northern climate, or a region more elevated above the level of the sea.

Numerous trunks of large and tall trees lie buried in the black mire of the morass. In so loose a soil they are easily overthrown by winds, and nearly as many have been found lying beneath the surface of the peaty soil, as standing erect upon it. When thrown down, they are soon covered by water, and keeping wet they never decompose, except the sap wood, which is less than an inch thick. Much of the timber is obtained by sounding a foot or two below the surface, and it is sawn into planks while half under water.

The Great Dismal has been described as being highest towards its centre. Here, however, there is an extensive lake of an oval form, seven miles long, and more than five wide, the depth, where greatest, fifteen feet ; and its bottom, consisting of mud like the swamp, but sometimes with a pure white sand, a foot deep, cov- 
ering the mud. The water is transparent, though tinged of a pale brown-colour, like that of our peatmosses, and contains abundance of fish. This sheet of water is usually even with its banks, on which a thick and tall forest grows. There is no beach, for the bank sinks perpendicularly, so that if the waters are lowered several feet it makes no alteration in the breadth of the lake.

Much timber has been cut down and carried out from the swamp by means of canals, which are perfectly straight for long distances, with the trees on each side arching over and almost joining their branches across, so that they throw a dark shade on the water, which of itself looks black, being coloured as before mentioned. When the boats emerge from the gloom of these avenues into the lake, the scene is said to be "as beautiful as fairy land."

The bears inhabiting the swamp climb trees in search of acorns and gum berries, breaking off large boughs of the oaks in order to draw the acorns near to them. These same bears are said to kill hogs and even cows. There are also wild cats, and occasionally a solitary wolf, in the morass.

That the ancient seams of coal were produced for the most part by terrestrial plants of all sizes, not drifted, but growing on the spot, is a theory more and more generally adopted in modern times, and the growth of what is called sponge in such a swamp, and in such a climate as the Great Dismal, already covering so many square miles of a low level region bordering the sea, and capable of spreading itself indefinitely over the adjacent country, helps us greatly to conceive the manner in which the coal of the ancient Carboniferous 
rocks may have been formed. The heat, perhaps, may not have been excessive when the coal-measures originated, but the entire absence of frost, with a warm and damp atmosphere, may have enabled tropical forms to flourish in latitudes far distant from the line. Huge swamps in a rainy climate, standing above the level of the surrounding firm land, and supporting a dense forest, may have spread far and wide, invading the plains, like some European peat-mosses when they burst; and the frequent submergence of these masses of vegetable matter beneath seas or estuaries, as often as the land sunk down during subterranean movements, may have given rise to the deposition of strata of mud, sand, or limestone, immediately upon the vegetable matter. The conversion of successive surfaces into dry land, where other swamps supporting trees may have formed, might give origin to a continued series of coal-measures of great thickness. In some kinds of coal, the vegetable texture is apparent throughout under the microscope ; in others; it has only partially disappeared; but even in this coal the flattened trunks of trees of the genera Lepidodendron, Sigillaria, and others, converted into pure coal, are occasionally met with, and erect fossil trees are observed in the overlying strata, terminating downwards in seams of coal. The chemical processes by which vegetable matter buried in the earth is gradually turned into coal and anthracite has been already explained (see above, p. 72.).

Before concluding the remarks which are naturally suggested by a visit to the Great Dismal, I shall say a few words on a popular doctrine, favoured by some geologists, respecting an atmosphere highly charged with 
oarbonic acid, in which the coal plants are supposed to have flourished. Some imagine the air to have been so full of choke-damp during the ancient era alluded to, that it was unfitted for the respiration of warm-blooded quadrupeds and birds, or even reptiles, which require a more rapid oxygenation of their blood than creatures lower in the scale of organization, such as have alone been met with hitherto in the Carboniferous and older strata. It is assumed that an excess of oxygen was set free when the plants which elaborated the coal subtracted many hundred million tons of carbon from the carbonic acid gas which previously loaded the air. All this carbon was then permanently locked up in solid seams of coal, and the chemical composition of the earth's atmosphere essentially altered.

But they who reason thus are bound to inform us what may have been the duration of the period in the course of which so much carbon was secreted by the powers of vegetable life, and, secondly, what accession of fresh carbonic acid did the air receive in the same. We know that in the present state of the globe, the air is continually supplied with carbonic acid from several sources, of which the three principal are, first, the daily putrefactien of dead animal and vegetable substances; secondly, the disintegration of rocks charged with carbonic acid and organic matter; and, thirdly, the copious evolution of this gas from mineral springs and the earth, especially in volcanic countries. By that law which causes two gases of different specific gravity, when brought into contact, to become uniformly diffused and mutually absorbed through the whole space which they occupy, the heavy carbonic acid finds its way upwards through all parts of the at- 
mosphere, and the solid materials of large forests are given out from the earth in an invisible form, or in bubbles rising through the water of springs. Peatmosses of no slight depth, and covering thousands of square miles, are thus fed with their mineral constituents without materially deranging the constituents of the atmosphere breathed by man. Thousands of trees grow up, float down to the delta of the Mississippi, and other rivers, and are buried, and yet the air, at the end of many centuries, may be as much impregnated with carbonic acid as before.

Coral reefs are year after year growing in the ocean -springs and rivers feed the same ocean with carbonic acid and lime; but we have no reason to infer that when mountain masses of calcareous rock have thus been gradually formed in the sea, any essential change in the chemical composition of its waters has been brought about. We have no accurate data as yet for measuring whether in our own time, or at any remote geological era, the relative supply and consumption of carbon in the air or the ocean causes the amount of those elements to vary greatly; but the variation, if admitted, would not have caused an excess, but rather a deficit of carbon in the periods most productive of coal or peat, as compared to any subsequent or antecedent epochs. In fact, a climate favouring the rank and luxurious growth of plants, and at the same time checking their decay, and giving rise to peat or accumulations of vegetable matter, might, for the time, diminish the average amount of carbonic acid in the atmosphere - $a$ state of things precisely the reverse of that assumed by those to whose views I am now objecting. 


\section{CHAPTER VIII.}

Tour to Charleston, South Carolina.-Facilities of Locomotion.Augusta.-Voyage down the Savannah River.-Shell Bluff.Slave-labour.-Fever and Ague.-Millhaven.-Pine Forests of Georgia.-Alligators and Land-Tortoises.-Warmth of Climate in January.-Tertiary Strata on the Savannah.-Fossil Remains of Mastodon and Mylodon near Savannah.-Passports required of Slaves.-Cheerfulness of the Negroes.

Dec. 28.-Charleston, South Carolina. We arrived here after a journey of 160 miles through the pine forests of North Carolina, between Weldon and Wilmington, and a voyage of about 17 hours, in a steam ship, chiefly in the night between Wilmington and this place. 'Here we find ourselves in a genial climate, where the snow is rarely seen, and never lies above an hour or two upon the ground. The rose, the narcissus, and other flowers, are still lingering in the gardens, the woods still verdant with the magnolia, live oak, and long-leaved pine, while the dwarf fan palm or palmetto, frequent among the underwood, marks a more southern region. In less than four weeks since we left Boston, we have passed from the $43 \mathrm{~d}$ to the $33 \mathrm{~d}$ degree of latitude, carried often by the power of steam for several hundred miles together through thinly peopled wildernesses, yet sleeping every night at good inns, and contrasting the facilities of locomotion in this new country with the difficulties we had contended with the year before when travelling in Europe, through populous parts of Touraine, Brittany, and other provinces of France. 
At Charleston I made acquaintance with several persons zealously engaged in the study of natural history, and then went by an excellent railway 136 miles through the endless pine woods to Augusta, in Georgia. This journey, which would formerly have taken a week, was accomplished between sunrise and sunset; and, as we scarcely saw by the way any town or village, or even a clearing, nor any human habitation except the station houses, the spirit of enterprise displayed in such public works filled me with astonishment which increased the farther I went South. Starting from the sea-side, and imagining that we had been on a level the whole way, we were surprised to find in the evening, on reaching the village of Aikin, sixteen miles from Augusta, that we were on a height several hundred feet above the sea, and that we had to descend a steep inclined plane to the valley of the Savannah river. The strata cut through here in making the railway consist of vermilion-coloured earth and clay, and white quartzose sand, with masses of pure white kaolin intermixed. These strata belong to the older or Eocene tertiary formation, which joins the clay-slate and granitic region a few miles above Augusta, where I visited the rapids of the Savannah.

I had been warned by my scientific friends in the North, that the hospitality of the planters might greatly interfere with my schemes of geologizing in the Southern states. In the letters, therefore, of introduction furnished to me at Washington, it was particularly requested that information respecting my objects, and facilities of moving speedily from place to place, should be given me, instead of dinners and society. These injunctions were every where kindly and politely com- 
plied with. It was my intention, for the sake of getting a correct notion of the low country between the granitic region and the Atlantic, to examine the cliffs bounding the Savannah river from its rapids to near its mouth, a distance, including its windings, of about 250 miles. After passing a few days at Augusta, where, for the first time, I saw cotton growing in the fields, I embarked in a steam-boat employed in the cotton trade, and went for forty miles down the great river, which usually flows in a broad alluvial plain, with an average fall of about one foot per mile, or 250 feet between Augusta and the sea. Like the Mississippi and all large rivers, which, in the flood season, are densely charged with sediment, the Savannah has its immediate banks higher than the plain intervening between them and the high grounds beyond, which usually, however distant from the river, present a steep cliff or "bluff" towards it. The low flat alluvial plain, overflowed in great part at this rainy season, is covered with aquatic trees, and an ornamental growth of tall canes, some of them reaching a height of twenty feet, being from one to two inches in diameter, and with their leaves still green. The lofty cedar (Cupressus disticha), now leafless, towers above them, and is remarkable for the angular bends of the top boughs, and the large thick roots which swell out near the base.

I landed first at a cliff about 120 feet high, called Shell Bluff, from the large fossil oysters which are conspicuous there. About forty miles below Augusta, at Demery's Ferry, the place where we disembarked, the waters were so high that we were carried on shore by two stout negroes. In the absence of the proprietor to whom I had letters, we were hospitably received by his 
overseer, who came down to the river bank, with two led horses, on one of which was a lady's saddle. $\mathrm{He}$ conducted us through a beautiful wood, where the verdure of the evergreen oaks, the pines, and hollies, and the mildness of the air, made it difficult for us to believe that it was mid-winter, and that we had been the month before in a region of snow storms and sledges. We crossed two creeks, and after riding several miles reached the house, and were shown into a spacious room, where a great wood fire was kept up constantly on the hearth, and the doors on both sides, left open day and night.

Returning home to this hospitable mansion in the dusk of the evening of the day following, I was surprised to see, in a grove of trees near the court-yard of the farm, a large wood-fire blazing on the ground. Over the fire hung three cauldrons, filled, as I afterwards learned, with hog's lard, and three old negro women, in their usual drab-coloured costume, were leaning over the cauldrons, and stirring the lard to clarify it. The red glare of the fire was reflected from their faces, and I need hardly say how much they reminded me of the scene of the witches in Macbeth. Beside them, moving slowly backwards and forwards in a rockingchair, sat the wife of the overseer, muffled up in a cloak, and suffering from a severe cold, but obliged to watch the old slaves, who are as thoughtless as children, and might spoil the lard if she turned away her head for a few minutes. When I inquired the meaning of this ceremony, I was told it was "killing time," this being the coldest season of the year, and that since I left the farm in the morning thirty hogs had been sacrificed by the side of a running stream not far off. 
These were destined to serve as winter provisions for the negroes, of whom there were about a hundred on this plantation. To supply all of them with food, clothes, and medical attendants, young, old, and impotent, as well as the able-bodied, is but a portion of the expense of slave-labour. They must be continually superintended by trustworthy whites, who might often perform no small part of the task, and far more effectively, with their own hands.

I fossilized for three days very diligently at Shell Bluff, obtaining more than forty species of shells, chiefly casts, referable to the Eocene formation; of which I shall speak by-and-by.

Resuming our voyage, thirty miles further down the river, in another large cotton steam-boat, we were landed at Stony Bluff, in Georgia, where I wished to examine the rocks of burr-stone. There was no living being or habitation in sight. The large steamer vanished in an instant, sweeping down the swollen river at the rate of seventeen miles an hour, and it seemed as if we had been dropped down from a balloon, with our luggage, in the midst of a wilderness. I began by exercising my hammer on the burr-stone of this low bluff; a cellular kind of flint, sometimes used for millstones, and full of silicified corals and minute shells, and, as I afterwards found, by aid of a powerful microscope, of sponges. It is an Eocene formation, and alternates with beds of red loam. After making a collection of specimens, I walked about the wood, and found a lone house, at the door of which a woman was sitting, in a languid state of health. She said she had just recovered from the fever, or chill; and among other inquiries, asked when we had last had this complaint. On 
being told we had never had it, she said, "I should like to live in your country, for among the Whites there is not one in this section of Georgia that has escaped." It is true, that consumption, so common in the Northern states, and so often fatal, is unknown here; but the universality of the ague makes these low districts in the Southern states most unenviable dwelling-places. The best season for a geological toür in this part of Georgia and South Carolina, east of the mountains, is from December to April inclusive.

I waited for the return of the owner of the lone house, and told him I wished to visit the plantation of Colonel Jones, at Millhaven. He consented to let me hire his barouche with one horse, telling me I must send it back the best way I could, after finding my own way for twelve miles through the pine forests, as he could spare me no driver. The lanes through the wood were numerous, and a storm had blown down so many tall pines across the road, each of which it was necessary to circumnavigate, that we thought ourselves fortunate when we arrived safe at the destined haven. My new host added to the kindness and frankness of a Southern planter, what I had little expected in the midst of this forest, a strong love for my favourite pursuits, and guided me at once to Jacksonborough, and other neighbouring places, best worthy the attention of a geologist.

We had many long rides together through those woods, there being no underwood to prevent a horse from galloping freely in every direction. The longleaved pines emit a faint odour somewhat resembling that of the hyacinth, and their bright-green foliage was finely brought out against the clear blue sky. The air 
was balmy, and unusually warm, even for Georgia in the first week of January. We saw several butterflies, one of a bright yellow colour, and bats flying about in the evening. The croaking of the frog and the chirping of the cricket were again heard. They had been silent a few days before, when the air was cooler. The sheep, which remain out in these woods all the winter, are now followed by lambs about three weeks old. I saw many black squirrels here, but only heard of the opossum, racoon, bear, and alligator, without seeing any. A few days ago, an alligator was shot fourteen feet long, in the act of carrying off a pig ; and the sportsmen complain to me that they devour their dogs when they follow the deer, which, on the first alarm, usually take to the Savannah river.

I frequently observed the holes of the gopher, a kind of land-tortoise, which burrows in the sand, and is now hybernating below ground. Four or five inhabit one hole; their eggs are rather smaller than a hen's. They are gregarious, and in summer are seen feeding ten or twelve together on the low shrubs. They are said to be very strong for their size, and a negro-woman assured a lady of our party that she was so light that she might be "toted by a gopher." We also saw small hillocks, such as are thrown up by our moles, made by a very singular animal, which they call a salamander, because, I believe, it is often seen to appear when the woods are burnt. It is not a reptile, but a species of rat (Pseudostoma pinetorum), with pouches on its cheeks.

On quitting Millhaven, instead of continuing my voyage down the river, I-hired a carriage to convey us to the town of Savannah, a distance of nearly one hun- 
dred miles. Here and there I went down from the high road to examine the river-cliffs, consisting of bright red-coloured loam, red and grey clay, and white sand. At Hudson's Reach and other points I found Eocene shells and fishes' teeth, chiefly of the genera $M y$ liobates and Lamna. One day, on returning from the river, I'came suddenly in the wood on some turkeybuzzards feeding on a dead hog. I had often seen since we crossed the Potomac these large black and grey birds soaring at a great height in the air, but I was now surprised to see one of them perch on a stump a few yards, from me, and seem perfectly fearless. In our last day's journey, I remarked, for the first time in Anterica, a large flight of rooks, some wheeling about in the air, others perched on trees.

Near the village of Ebenezer we passed over a long causeway, made of logs, which for three quarters of a mile was under water. The tall cedars (Cupressus disticha), and other trees arching over and forming a long aisle, reminded me exactly of the descriptions given of the canals in the Great Dismal Swamp. Some of the myrtles in these wet grounds are very fragrant.

We were pursuing a line of road not much frequented of late, since the establishment of the railway from Augusta to Charleston. Our arrival, therefore, at the inns was usually a surprise, and instead of being welcomed, we were invariably recommended to go on farther. When once admitted, we were made very comfortable, having our meals with the family, and being treated more like guests than customers. On one occasion our driver, to whose brother our carriage and horses belonged, fell in with the son of a neighbouring planter, 
who reproached him in a friendly manner for not having come to his house the night before, and brought us with him. The social equality which prevails here arises not so much from the spirit of a republican government, as from the fact of the whites constituting an aristocracy for whom the negroes work. Had we availed ourselves of letters of introduction freely offered to us, we might have passed from the house of one hospitable planter to another, and heard as little of reckonings at inns as Don Quixote expected, after his study of the histories of knights errant.

Jan. 10. 1842.-On the tenth day after leaving Augusta, we arrived at Savannah, from which town I immediately set out on an excursion through a flat, swampy country, resembling a large delta, to Beauly and the Vernon river, about fifteen miles to the southeast. I went by Heyner's Bridge, on the White Bluff creek, to see a spot about twelve miles from Savannah, where $\mathbf{I}$ had learnt from Dr. Habersham that bones of the mastodon and other extinct mammalia had been discovered. The bed of clay, about six feet thick, containing them, can only be seen at low water, and I descended to it in a boat when the tide was out; and by the aid of the negroes, obtained the grinder of the common American mastodon. The stratum enclosing these and other bones rests immediately on sand containing marine shells of living species, and is covered by the mud of a freshwater swamp, in which trees grow, and when thrown down by the winds, become occasionally imbedded. One of the teeth given to me from this place by Dr. Habersham was ascertained, by Mr. Owen, to be referable to his new genus, Mylodon. Mr. Hamilton Couper afterwards sent me from a similar 
geological position, farther south in Georgia, near the mouth of the Altamaha, the tooth of a megatherium. It is evident, from his observations and my own, that at a comparatively recent period since the Atlantic was inhabited by the existing species of marine testacea, there was an upheaval and laying dry of the bed of the ocean in this region. The new land supported forests in which the megatherium, mylodon, mastodon, elephant, a species of horse different from the common one, and other quadrupeds, lived, and were occasionally buried in the swamps. There have also been subsidences on the coast, and perhaps, far inland; for in many places near the sea there are signs of the forest having become submerged, the remains of erect trees being seen enveloped in stratified mud and sand: I even suspect that this coast is now sinking down, at a slow and insensible rate, for the sea is encroaching and gaining at many points on the freshwater marshes. Thus at Beauly I found upright stumps of trees of the pine, cedar, and ilex covered with live oysters and barnacles, and exposed at low tide; the deposit in which they were buried having been recently washed away from around them by the waves. I also observed, that the flat country of marshes was bounded on its western or inland side by a steep bank or ancient cliff cut in the sandy tertiary strata, and there are other inland cliffs of the same kind at different heights implying the successive elevation above the sea of the whole tertiary region.

Not only in South Carolina and Georgia, but also in the low region of North Carolina, as, for example, fifteen miles below Newbern, the remains of extinct quadrupeds have been met with. The tooth of a 
horse found in the latter place, with the bones of mastodon, elephant, and other mammalia, was presented to me by Mr. Conrad, remarkably curved, and agreeing, in this respect, with a fossil tooth discovered by Mr. Darwin on the north side of the Plata, in Entre Rios, in South America, where it accompanied the mastodon and megatherium. As no species of equus existed in the New World when it was discovered in the fifteenth century, naturalists were inclined, at first, to be incredulous in regard to the real antiquity of this fossil; but as the tooth is more curved than in the recent horse, ass, or zebra, the fossil species may have differed as widely from any living representative of this genus, as the zebra or wild ass from the horse of Arabia.

It is a fact well worthy of attention that in the southern states of the Union so many extinct quadrupeds, such as the mastodon, elephant, megatherium, mylodon, and horse, should occur, agreeing, some specificially and others in generic characters, with those found in corresponding latitudes in South America near the river Plata, and in Patagonia, or between latitudes $31^{\circ}$ and $50^{\circ} \mathrm{S}$., and that in both hemispheres they should be accompanied by marine fossil shells of recent species, as Mr. Darwin has shown to be the case in the Pampas. Yet, although these quadrupeds are so modern, geologically speaking, as to have co-existed with the present testaceous fauna, we cannot attribute their extermination to the agency of man; for it is not the huge beasts alone, but quadrupeds as small as the rat, which have become extinct in South America within the same period, as Mr. Lund, the Danish naturalist, has shown in reference to Brazil.

On the beach at Beauly I saw numerous foot-tracks 
of racoons and opossums on the sand, which had been made during the four hours immediately preceding, or since the ebbing of the tide. Already some of them were half filled with fine blown sand, showing the process by which distinct casts may be formed of the footsteps of animals in a stratum of quartzose sandstone. I remarked that the tracks of the racoons could be traced at several points to beds of oysters, on which these animals are said to feed. The negroes told me, that sometimes a large oyster closes his shell suddenly, and holds the racoon fast by his paw till the returning tide comes up and drowns him.

The surface of the beach for half a mile was covered with small round pellets of mud as thick as hailstones, of the size of currants and peas, and arranged for the most part in small heaps. These are made by thousands of land crabs (Gelasimus vocans?), which they call fiddlers, because the motion of their claws is compared to the arm of a player on the violin. By the side of each heap was a perpendicular hole several inches deep, into which when alarmed the crab retreats sideways, sometimes disappearing, but often leaving the larger claw projecting above for want of room. They make these holes by rolling the wet sand into pellets, and then bringing up each ball separately to the surface.

A planter of this country told me it was amusing to see a flock of turkies driven down for the first time from the interior to feed on the crabs in the marine marshes. They, at first, walk about in a ludicrous state of alarm, expecting their toes to be pinched, but after a time, one bolder than the rest is tempted by hunger to snap up a small fiddler, after which the rest fall to and devour 
them by thousands. On my way through the woods in this low region near Savannah, I saw some fine magnolias ninety feet high, palmettos six feet high in tufts, and oaks hung with white pendant wreaths, sometimes ten feet long, of the wiry parasitic Tillandsia usnæoides. This climber, which also festoons the woods in South America, much resembles the lichen called in England "old man's beard," but is a phenogamous plant.

In order to see the bed of clay containing the bones of the mastodon at Heyner's Bridge, it was necessary for me to be on the ground by daybreak at low tide. With this view, I left Savannah in the middle of the night. The owner of the property kindly lent me his black servant as a guide, and I found him provided with a passport, without which no slave can go out after dusk. The exact streets through which he was to pass in his way to me were prescribed, and had he strayed from this route he might have been committed to the guard-house. These and other precautionary regulations, equally irksome to the slaves and their masters, are said to have become necessary after an insurrection brought on by abolitionist missionaries, who are spoken of here in precisely the same tone as incendiaries, or beasts of prey whom it would be meritorious to shoot or hang. In this savage and determined spirit I heard some planters speak who were mild in their manners, and evidently indulgent to their slaves. Nearly half the entire population of this state are of the coloured race, who are said to be as excitable as they are ignorant. Many proprietors live with their wives and children quite isolated in the midst of the slaves, so 
that the danger of any popular movement is truly appalling.

The negroes, so far as I have yet seen them, whether in domestic service or on the farms, appear very cheerful and free from care, better fed than a large part of the labouring class of Europe ; and, though meanly dressed, and often in patched garments, never scantily clothed for the climate. We asked a woman in Georgia, whether she was the slave of a family of our acquaintance. She replied, merrily, "Yes, I belong to them, and they belong to me." She was, in fact, born and brought up on the estate.

On another occasion we were proceeding in a wellappointed carriage with a planter, when we came unexpectedly to a dead halt. Inquiring the cause, the black coachman said he had dropped one of his white gloves on the road, and must drive back and try to find it. He could not recollect within a mile where he had last seen it: we remonstrated, but in vain. As time pressed, the master in despair took off his own gloves, and saying he had a second pair, gave them to him. When our charioteer had deliberately put them on, we started again. 


\section{CHAPTER IX.}

Return to Charleston._Fossil Human Skeleton.-Geographical Distribution of Quadrupeds in North America.-Severe Frost in 1835 in South Carolina.-White Limestone of the Cooper River and Santee Canal.-Referred to the Eocene Period, not intermediate between Tertiary and Chalk.-Lime-sinks.-Species of Shells common to Eocene Strata in America and Europe.-Causes of the increased Insalubrity of the Law Region of South Carolina.-Condition of the Slave Population.--Cheerfulness of the Negroes: their Vanity.-State of Animal Existence.-Invalidity of Marriages.-The Coloured Population multiply faster than the Whites. - Effects of the Interference of Abolitionists.-Laws against Edu. cation.-Gradual Emancipation equally desirable for the Whites and the Coloured Race.

Jan. 13. 1842.-From Savannah we returned to Charleston in a steam-ship, on board of which we found an agreeable party, consisting chiefly of officers of the U. S. army returning from Florida, where they had nearly brought to a close a war of extermination carried on for many years against the Seminole Indians. They gave a lively picture of the hardships they underwent in the swamps and morasses during this inglorious campaign, in the course of which the lives of perhaps as many whites as Seminoles were sacrificed. The war is said to have been provoked by the attacks of the Indians on new settlers.

In the Museum at Charleston, I was shown a fossil human skull from Guadaloupe, imbedded in solid limestone, which they say belongs to the same skeleton of a female as that now preserved in the British Museum, where the skull is wanting. 
Dr. Bachman, whom I saw here, is engaged in a great work on the quadrupeds of North America. He pointed out to me the boundary of several distinct zones of indigenous mammalia, extending east and west on this continent, where there are no great natural barriers running in the same direction, such as mountain ridges, deserts, or wide arms of the sea to check the migrations of species. The climate alone has been sufficient to limit their range. The mammiferous fauna of the State of New York, comprising about forty species, is distinct from that of the arctic region 600 miles north of it, and described by Dr. Richardson. It is equally distinct from that of South Carolina and Georgia, a territory about as far distant to the south. In Texas, where frosts are unknown, another assemblage of species is met with. The opossum, for example, of that country (Didelphis cancrivora) is different from that of Virginia. The latter (Didelphis virginiana) is one of those species which is common to many provinces, extending from Florida as far north as Pennsylvania, where it has been observed while the snow was lying two feet deep on the ground. The racoon has a still wider habitation, ranging as did the buffalo originally (Bison americanus) from the north of Canada to the Gulf of Mexico. But these are exceptions to the general rule. Similar restrictions seem to have prevailed in the era of extinct quadrupeds, the great mastodon (M. giganteus) having evidently abounded in Canada and New York, as well as Kentucky and Georgia, while the megatherium and mylodon were almost entirely confined to the Southern States.

When discoursing here on the influence of climate, many accounts were given me of a frost which visited 
Charleston n February, 1835, so severe that wine was frozen in bottles. The tops of the Pride-of-India tree, of Chinese origin, were killed : all the oranges, of which there were large orchards, were destroyed. Beds of oysters, exposed between high and low water mark, perished in the estuaries, and the effluvia from them was so powerful as to injure the health of the inhabitants.

Several planters attribute the failure of the cotton crop this year (1842) to the unusual size and number of the icebergs, which floated southwards last spring from Hudson's and Baffin's Bays, and may have cooled the sea and checked the early growth of the cotton plant. So numerous and remote are the disturbing causes in meteorology! Forty degrees of latitude intervene between the region where the ice-floes are generated and that where the crops are raised, whose death-warrant they are supposed to have carried with them.

Before I visited the Southern States, I had heard from several American geologists that calcareous rocks occurred there intermediate in age between the chalk and the tertiary formations, and helping to fill the void which separates those two well-marked eras in the European series. Having satisfied myself that all the white limestone of the Savannah river was referable to the Eocene epoch, I now set out to determine whether the same could be said of that exposed to view on the Cooper river and Santee canal, about thirty miles north of Charleston. I was accompanied in an excursion of a week by Dr. Ravenel, who kindly offered to be my guide; and we first visited a plantation of his, called "The Grove," near the mouth of the Cooper river, 
where, in the marshes, there are deep deposits of clay and sand, enclosing the stools and trunks of the cypress, hickory, and cedar, often imbedded in an erect position, which must have grown in fresh water, but are now sunk six and even sixteen feet below the level of high water. Every where there are proofs of the coast having sunk, and the subsidence seems to have gone on in very modern times ; for some old cedars still standing on the surface have been killed by the encroachment of the salt water. We had come from Charleston in a small private steam-boat, and after passing Strawberry Ferry and entering the Santee Canal, were allowed by favour to pass through the locks without paying tolls, and, contrary to the usual regulations, which exclude steam-boats. The thoughtless negroes allowed the chimney of our vessel to get so choked up with soot that we were soon forced to quit this conveyance, and travel by land. The barges on the canal are constructed of different sizes, so that, after going down laden with cotton, they are put one into another when returning empty, and thus escape a large part of the tolls at the locks. The slaves are fond of cockfighting; and on the prow of each barge there stood usually a game-cock, perched as if he were the ensign of the vessel.

We passed the Brygon Swamp, about forty miles north of Charleston, where the remains of the mastodon were found when the canal was cut. Wild animals might still be mired in the same morass, latitude $33^{\circ} 20^{\prime} \mathrm{N}$., showing that these fossils in the Southern States occur in precisely the same geological position as in New York and Canada. We slept at Wantcot, and then went by Eutaw to Vance's Ferry on the Santee 
river, then to Cave Hall, examining the tertiary white marl and limestone, and collecting the shells and corals contained in it. Lime-sinks, or funnel-shaped cavities, are frequent in this country, arising from natural tunnels and cavities in the subjacent limestone, through some of which subterranean rivers flow. An account was given me of a new hollow which opened about fifteen years ago, about two miles south of the Santee river, into which a mule drawing a plough sank suddenly. About a hundred yards from the same spot, I saw a large cavern sixty feet high at its entrance in the white limestone, from the mouth of which flowed a small stream. The undermining effect of such rivers explains the linear arrangement so common in limesinks in South Carolina and Georgia. The walls of such "sinks" are vertical, and the strata exposed to view consist usually of clay and sand, which rest upon the limestone.

From Cave Hall we went in a north-westerly direction to Stoudenmire Creek, a tributary of the Santee, where the siliceous burr-stone and brick-red loam appear above the white limestone. In the course of this examination, I satisfied myself that the limestone and white marl, a formation which must sometimes amount to 120 feet in thickness, in the low region of Cooper river and the Santee canal, are a continuation of the same Eocene deposit which I had seen at Shell Bluff, at Jacksonboro', and other places on the Savannah river, and which I afterwards observed at Wilmington, in North Carolina. I found many species in all these places, common to those of Claiborne, in Alabama, where the largest number (more than 200) of Eocene shells in a good state of preservation have been met 
with; and are described and figured in the works of Mr. Conrad and Mr. Lea of Philadelphia. Dr. Ravenel pointed out to me some remarkable new species of Scutella at the Grove, near the mouth of the Cooper river, and these were accompanied by several wellknown Eocene shells like those of Claiborne. The same white limestone and marl may be said to be continuous for forty miles, from the Grove to the Santee river.

At Eutaw and other points, corals of the genera Idmonea, Acystis, Pustulopora, Vincularia, and Eschara occur, with a species of Scalaria, and other shells. These fossils, and the rock containing them, reminded me so much of the straw-coloured limestone of the cretaceous formation seen on the banks of Timber Creek in New Jersey, that I do not wonder that some errors had arisen from confounding the tertiary and secondary deposits of the south. The species, however, prove on closer inspection to be difierent. This lithological resemblance of the rocks seems to have led to the admission into Dr. Morton's list of the cretaceous fossils of North America; a list for the most part very correct, of the following seven tertiary species which really came from the Eocene strata of South-Carolina. These are, Balanus peregrinus, Pecten calvatus, P. membranosus, Terebratula lachryma, Conus gyratus, Scutella Lyelli, and Echinus infulatus (see Morton's Synopsis, pl. 10.). The belief that all these species were common to the chalk and tertiary strata led naturally to the opinion that in the Southern States a formation existed intermediate in character between the rocks of the secondary and those of the tertiary periods. 
I consider the burr-stone and associated clays and sands of Stoudenmire and Aikin, South Carolina, and of Augusta, Millhaven, and Stony Bluff, in Georgia, to belong also to an Eocene deposit, and to be- higher in the series than the white limestone formation.

Out of 125 species of Eocene shells which I collected in the Southern States, or which were presented to me, I have only been able to identify seven with European species of the same epoch. These are Trochus agglutinans, Solarium canaliculatum, Bonellia terebellata, Infundibulum trochiforme, Lithodomus dactylus, Cardita planicosta, and Ostrea bellovacina.

But there are a considerable number of representative species, and an equal number of forms peculiar to these older tertiary strata of America.

The Ostrea sellaformis, which may be considered as representing the $\boldsymbol{O}$. flabellula of the Paris and London basins, appears to be one of the most characteristic and widely disseminated Eocene shells in Virginia, South Carolina, and Georgia, for I found it at Shell Bluff and on the Santee river, and the James river, in Virginia.

On the banks of the Cooper river, we heard occasionally the melodious and liquid note of the mockingbird in the woods. It is of a fearless disposition, and approaches very near to the houses. I can well imagine that in summer, when the leaves are out, and the flowers in full splendour, this region must be most beautiful. But it is then that the planters are compelled by the fever and ague to abandon their country seats. It was not so formerly. When the English army was campaigning on the Cooper and Santee rivers in the revolutionary war, they encamped with impunity in places 
where it would now be death to remain for a few days in the hot season. I inquired what could have caused so great a change, and found the phenomenon as much a matter of controversy as the origin of the malaria in Italy. The clearing away of the wood from large spaces is the chief alteration in the physical condition of this region in the course of the last sixty years, whereby the damp and swampy grounds undergo annually the process of being dried up by a burning sun. Marshes which are overflowed by the tide twice in every twenty-four hours near the neighbouring coast, both in South Carolina and Georgia, are perfectly healthy. $\mathrm{Dr}$. Arnold remarks, in his Roman History, that Rome was more healthy before the drainage of the Campagna, and when there was more natural wood in Italy and in northern Europe generally. In the southern States of the Union there are no fevers in winter, at a season when there is no large extent of damp and boggy soil exposed to a hot sun, and undergoing desiccation.

On our way home from Charleston, by the railway from Orangeburg, I observed a thin black line of charred vegetable matter exposed in the perpendicular section of the bank. The sand cast out in digging the railway had been thrown up on the original soil, on which the pine forest grew ; and farther excavations had laid open the junction of the rubbish and the soil. As geologists, we may learn from this fact how a thin seam of vegetable matter, an inch or two thick, is often the only monument to be looked for of an ancient surface of dry land, on which a luxuriant forest may have grown for thousands of years. Even this seam of friable matter may be washed away when the region is submerged, and, if not, rain-water percolating freely through the 
sand may, in the course of ages, gradually carry away the carbon.

As there were no inns in that part of South Carolina through which we passed in this short tour, and as we were every where received hospitably by the planters, I had many opportunities of seeing their mode of life, and the condition of the domestic and farm slaves. In some rich houses maize, or Indian corn, and rice were entirely substituted for wheaten bread. The usual style of living is that of English country gentlemen. They have well-appointed carriages and horses, and well-trained black servants. The conversation of the gentlemen turne chiefly on agricultural subjects, shooting, and horse-racing. Several of the mansions were surrounded with deer-parks.

Arriving often at a late hour at our quarters in the evening, we heard the negroes singing loudly and joyously in chorus after their day's work was over. On one estate, about forty black children were brought up daily before the windows of the planter's house, and fed in sight of the family, otherwise, we were told, the old women who have charge of them might, in the absence of the parents, appropriate part of their allowance to themselves. All the slaves have some animal food daily. When they are ill, they sometimes refuse to take medicine, except from the hands of the master or mistress; and it is of all tasks the most delicate for the owners to decide when they are really sick, and when only shamming from indolence.

After the accounts I had read of the sufferings of slaves, I was agreeably surprised to find them, in general, so remarkably cheerful and light-hearted. It is true that I saw no gangs working under overseers on sugar- 
plantations, but out of two millions and a half of slaves in the United States, the larger proportion are engaged in such farming occupations and domestic services as I witnessed in Georgia and South Carolina. I was often for days together with negroes who served me as guides, and found them as talkative and chatty as children, usually boasting of their master's wealth, and their own peculiar merits. At an inn in Virginia, a female slave asked us to guess for how many dollars a year she was let out by her owner. We named a small sum, but she told us exultingly, that we were much under the mark, for the landlord paid fifty dollars, or ten guineas a year for her hire. A good-humoured butler, at another inn in the same state, took care to tell me that his owner got $30 l$. a year for him. The coloured stewardess of a steam-vessel was at great pains to tell us her value, and how she came by the name of Queen Victoria. When we recollect that the dollars are not their own, we can hardly refrain from smiling at the childlike simplicity with which they express their satisfaction at the high price set on them. That price, however, is a fair test of their intelligence and moral worth, of which they have just reason to feel proud, and their pride is at least free from all sordid and mercenary considerations. We might even say that they labour with higher motives than the whites - a disinterested love of doing their duty. I am aware that we may reflect and philosophise on this peculiar and amusing form of vanity, until we perceive in it the evidence of extreme social degradation; but the first impression which it made upon my mind was very consolatory, as I found it impossible to feel a painful degree of commiseration for persons so exceedingly well satisfied with themselves. 
South Carolina is one of the few states where there is a numerical preponcierance of slares. One night, at Charleston, I went to see the guard-house, where there is a strong guard kept constantly in arms, and on the alert. Every citizen is obliged to serve in person, or find a substitute; and the maintenance of such a force, the strict laws against importing books relating to emancipation, and the prohibition to bring back slaves who have been taken by their masters into free states, show that the fears of the owner, whether well-founded or not, are real.

During our stay at Charleston, we were present at a negro wedding, where the bride and bridegroom, and nearly all the company, were of unmixed African race. They were very merry. The bride and bridemaids all dressed in white. The marriage service performed by an Episcopal clergyman. Not long afterwards, when staying at a farm-house in North Carolina, I happened to ask a planter if one of his negroes with whom we had been conversing was married. He told me, Yes, he had a wife on that estate, as well as another, her sister, on a different property which belonged to him; but that there was no legal validity in the marriage ceremony. I remarked, that he must be mistaken, as an Episcopal minister at Charleston would not have lent himself to the performance of a sacred rite, if it were nuggatory in practice, and in the eye of the law. He replied, that he himself was a lawyer by profession, and that no legal validity ever had been, or ought to be, given to the marriage tie, so long as the right of sale could separate parent and child, husband and wife. Such separations, he said, could not always be prevented, when slaves multiplied fast, though they were avoided 
by the masters as far as possible. He defended the custom of bringing up the children of the same estate in common, as it was far more humane not to cherish domestic ties among slaves. On the same farm I talked with several slaves who had been set to fell timber by task-work, and had finished by the middle of the day. They never appeared to be overworked; and the rapidity with which they increase beyond the whites in the United States shows that they are not in a state of discomfort, oppression, and misery. Doubtless, in the same manner as in Ireland and parts of Great Britain, the want of education, mental culture, and respect for themselves, favours improvident marriages among the poor ; so the state of mere animal existence of the slave, and his low moral and intellectual condition, coupled with kind treatment and all freedom from care, promote their multiplication. The effect of the institution on the progress of the whites is most injurious, and, after travelling in the northern States, and admiring their rapid advance, it is most depressing to the spirits. There appears to be no place in society for poor whites. If they are rich, their slaves multiply, and from motives of kindly feeling towards retainers, and often from false pride, they are very unwilling to sell them. Hence they are constantly tempted to maintain a larger establishment than is warranted by the amount of their capital, and they often become involved in their circumstances, and finally bankrupt. The prudence, temper, and decision of character required to manage a plantation successfully is very great. It is notorious that the hardest taskmasters to the slaves are those who come from the northern free States.

I often asked myself, when in the midst of a large 
plantation, what steps I would take if I had inherited such a property from British ancestors. I thought, first, of immediately emancipating all the slaves, but I was reminded that the law humanely provides, in that case, that I should still support them, so that I might ruin myself and family; and it would still be a question whether those whom I had released from bondage would be happier, or would be prepared for freedom. I then proposed to begin with education as a preliminary step. Here I was met with the objection that, since the abolition movement and the fanatical exertions of missionaries, severe statutes had been enacted, making it penal to teach slaves to read and write. I must first, therefore, endeavour to persuade my fellow slaveholders to repeal these laws against improving the moral and intellectual condition of the slaves. I remarked that, in order to overcome the apathy and reluctance of the planters, the same kind of agitation, the same "pressure from without," might be indispensable, which had brought about our West Indian emancipation. To this my American friends replied, that the small number of our slaves, so insignificant in comparison to their two and a half millions, had made an indemnity to the owner possible; also that the free negroes, in small islands, could always be held in subjection by the British fleets ; and, lastly, that England had a right to interfere and legislate for her own colonies, whereas the northern States of the Union, and foreigners, had no constitutional right to intermeddle with the domestic concerns of the slave States. Such intervention, by exciting the fears and indignation of the planters, had retarded, and must always be expected to retard, the progress of the cause. They also reminded 
me how long and obstinate a struggle the West Indian proprietors had made against the emancipationists in the British House of Commons ; and they hinted, that if the different islands had been directly represented in the Lower House, and there had been Dukes of Jamaica, Marquises of Antigua, and Earls of Barbadoes in the Upper House, as the slave states are represented in Congress, the measure would never have been carried to this day.

The more I reflected on the condition of the slaves, and endeavoured to think on a practicable plan for hastening the period of their liberation, the more difficult the subject appeared to me, and the more I felt astonished at the confidence displayed by so many anti-slavery speakers and writers on both sides of the Atlantic. The course pursued by these agitators shows that, next to the positively wicked, the class who are usually called "well-meaning persons" are the most mischievous in society. Before the year 1830, a considerable number of the planters were in the habit of regarding slavery as a great moral and political evil, and many of them openly proclaimed it to be so in the Virginia debates of 1831-2. The emancipation party was gradually gaining ground, and not unreasonable hopes were entertained that the States of Kentucky; Virginia, and Maryland would soon fix on some future day for the manumission of their slaves. This step had already been taken in most of the States north of the Potomac, and slavery was steadily retreating southwards. From the moment that the abolition movement began, and that missionaries were sent to the southern States, a re-action was perceived - the planters took the alarmlaws were passed against education-the condition of 
the slave was worse ; and not a few of the planters, by dint of defending their institutions against the arguments and misrepresentations of their assailants, cáme actually to delude themselves into a belief that slavery was legitimate, wise, and expedient-a positive good in itself. There were many, indeed, who thought differently, but who no longer dared to express their opinions freely on the subject.

It is natural that those planters who are of benevolent dispositions, and indulgent to their slaves, and who envy the northern proprietor, who, now that the Indians have passed away, has the good fortune not to share his country with another race, should be greatly irritated when the cruelty of the slave-holders, as a class, is held up to the reprobation of mankind. A deep sense of injustice, and a feeling of indignation, disinclines them to persevere in advocating the cause of emancipation. I was so much occupied and absorbed in my scientific pursuits that I never felt tempted to touch on this exciting subject, and therefore, perhaps, the planters spoke out their sentiments to me more freely. "Labour," they said, "is as compulsory in Europe as here; but in Europe they who refuse to work have the alternative of starvation; here the slave who is idle has the alternative of corporal punishment; for, whether he works or not, he must always be fed and clothed." They complained to me much of the manner in which the escape of runaway slaves was favoured in the free States. Their innocence, they said, is always assumed, and the cruelty and harshness of their owners, taken for granted; whereas the fugitives often consist of good-for-nothing characters, who would have been put into gaul in Europe, but who here are left at large, 
Chap. ix. effects of suduen emancipation. 151

because their masters are unwilling to lose their services by imprisonment, while they are compelled to support them. If the same delinquents, they say, were flying from the constable in a free State, the public would sympathise with the police and the magistrate, and if they bore on their backs the marks of former chastisement in gaol, the general desire to apprehend them would be still more eager. These apoloyies, and their assurance that they found it to their interest to treat their slaves kindly, had, no effect in inducing me to believe that, where such great power is intrusted to the owner, that power will not be frequently abused; but it has made me desire to see a fair statement of the comparative statistics of crimes and punishments in slave states and free countries. If we could fairly estimate the misery of all offenders in the prisons, penitentiaries, and penal settlements of some large European province, and then deduct the same from the sufferings of the slaves in a large southern state of the Union, the excess alone ought, in fairness, to be laid to the charge of the slave-owners. While pointing out the evil unreservedly, we should do the owner the justice to remember that the system of things which we deprecate has been inherited by him from his British ancestors, and that it is rarely possible or safe to bring about a great social reform in a few years.

Had the measure of emancipating all the slaves been carried through as rapidly as some abolitionists have desired, the fate of the negroes might have been almost as deplorable as that of the aboriginal Indians. We must never forget that the slaves have at present a monopoly of the labour-market; the planters being 
bound to feed and clothe thers, and being unable to turn them off and take white labourers in their place. The coloured population, therefore, are protected against the free competition of the white emigrants, with whom, if they were once liberated, they could no longer successfully contend. I am by no means disposed to assume that the natural capacities of the negroes, who always appeared to me to be an amiable, gentle, and inoffensive race, may not be equal in a moral and intellectual point of view to those of the Europeans, provided the coloured population were placed in circumstances equally favourable for their development. But it would be visionary to expect that, under any imaginable system, this race could at once acquire as much energy, and become as rapidly progressive, as the AngloSaxons. To inspire them with such an aptitude for rapid advancement must be the work of time-the result of, improvement carried on through several successive generations. Time is percisely the condition for which the advocates of the immediate liberation of the blacks would never sufficiently allow. The great experiment now making in the West Indies affords no parallel case, because the climate there is far more sultry, relaxing, and trying to Europeans, than in the Southern States of the Union; and it is well known that the West Indian proprietors have no choice, the whites being so few in number, that the services of the coloured race are indispensable.

Professor Tucker, of Virginia, has endeavoured to show, that the density of population in the slave States will amount, in about sixty years, to fifty persons in a square mile. Long before that period arrives, the most productive lands will have been all cultivated, and some 
of the inferior soils resorted to: the price of labour will fall gradually as compared to the means of subsistence, and it will, at length, be for the interest of the masters to liberate their slaves, and to employ the more economical and productive labour of freemen. The same causes will then come into operation which formerly emancipated the villeins of western Europe, and will one day set free the serfs of Russia. It is to be hoped, however, that the planters will not wait for more than half a century for such an euthanasia of the institution of slavery; for the increase of the coloured population in sixty years would be a formidable evil, since in this instance they are not, like villeins and serfs, of the same race as their masters. They cannot be fused at once into the general mass, and become amalgamated with the whites, for their colour still remains as the badge of their former bondage, so that they continue, after their fetters are removed, to form a separate and inferior caste. How long this state of things would last must depend on their natural capabilities, moral, intellectual, and physical; but if in these they be equal to the whites, they would eventually become the dominant race, since the climate of the south, more congenial to their constitutions, would give them a decided advantage.

A philanthropist may weil be perplexed when he desires to devise some plan of interference which may really promote the true interests of the negro. But the way in which the planters would best consult their own interests appears to me very clear. They should exhibit more patience and courage towards the abolitionists, whose influence and numbers they greatly overrate, and lose no time in educating the slaves, and 
encouraging private manumission to prepare the way for general emancipation. All seem agreed that the states most ripe for this great reform are Maryland, Virginia, North Carolina, Tennessee, Kentucky, and Missouri. Experience has proved in the northern States that emancipation immediately checks the increase of the coloured population, and causes the relative number of the whites to augment very rapidly. Every year, in proportion as the north-western States fill up, and as the boundary of the new settlers in the west is removed farther and farther, beyond the Mississippi and Missouri, the cheaper and more accessible lands south of the Potomac will offer a more tempting field for colonisation to the swarms of New Englanders, who are averse to migrating into slave states. Before this influx of white labourers, the coloured race will give way, and it will require the watchful care of the philanthropist, whether in the north or south, to prevent them from being thrown out of employment, and reduced to destitution.

If due exertions be made to cultivate the minds, and protect the rights and privileges of the negroes, and it nevertheless be found that they cannot contend, when free, with white competitors, but are superseded by them, still the cause of humanity will have gained. The coloured people, though their numbers remain stationary, or even diminish, may in the mean time be happier than now, and attain to a higher moral rank. They would, moreover, escape the cruelty and injustice which are the invariable consequences of the exercise of irresponsible power, especially where authority must be sometimes delegated by the planter to agents of inferior education and coarser feelings. And last, 
Chap. ix.

not least, emancipation would effectually put a stop to the breeding, selling, and exporting of slaves to the sugar-growing States of the South, where, unless the accounts we usually read of slavery be exaggerated and distorted, the life of the negro is shortened by severe toil and suffering.

Had the white man never interposed to transplant the negro into the New World, the most generous asserters of the liberties of the coloured race would have conceded that Africa afforded space enough for their development. Neither in their new country, nor in that of their origin, whether in a condition of slavery or freedom, have they as yet exhibited such superior qualities and virtues as to make us anxious that additional millions of them should multiply in the southern States of the Union; still less, that they should overflow into Texas and Mexicc. 


\section{CHAP'TER X.}

Wilmington, N. C.-Mount Vernon.-Return to Philadelphia.Reception of Mr. Dickens.-Museum and Fossil human Bones.Penitentiary.-Churches.-Religious Excitement.-Coloured People of Fortune.-Obstacles to their obtaining Political and Social Equality. - No natural Antipathy between the Races. - Negro Reservations.

Jan. 22.-I Now turned my course northwards, and, after a short voyage in a steamer from Charleston, landed at Wilmington, in North Carolina. Here I collected fossils from tertiary formations of two ages, the Miocene marls, and an underlying Eocene limestone, harder than that of Shell Bluff and the Santee canal before mentioned; but containing many of the same shells, corals, and teeth of fishes. I then went by railway to South Washington, visiting several farms on the banks of the north-east branch of Cape Fear river. Here I found cretaceous green marls, similar to those which I had seen 350 miles to the N. E. in New Jersey, with belemnites and other characteristic organic remains, some of species not previously known.

On several of the small plantations here I found the proprietors by no means in a thriving state, evidently losing ground from year to year, and some of them talking of abandoning the exhausted soil, and migrating with their slaves to the south-western States. If, while large numbers of the negroes were thus carried to the South, slavery had been abolished in North Carolina, the black population might ere this have been 
reduced considerably in numbers, without suffering those privations to which a free competition with white labourers must expose them, wherever great facilities for emigration are not afforded.

A railway train shooting rapidly in the dark through the pine forests of North Carolina has a most singular appearance, resembling a large rocket fired horizontally, with a brilliant stream of revolving sparks extending behind the engine for several hundred yards, each spark being a minute particle of wood, which, after issuing from the chimney of the furnace, remains ignited for several seconds in the air. Now and then these fiery particles, which are invisible by day, instead of lagging in the rear, find entrance by favour of the wind through the open windows of the car, and, while some burn holes in the traveller's cloak, others make their way into his eyes, causing them to smart most painfully.

At Petersburg, Mr. Ruffin, the agriculturist, and Mr. Tuomey, accompanied me in an excursion to collect tertiary fossils in the neighbourhood, and I examined with much instruction the organic remains in their cabinets. At Washington I saw M. Nicollet, and had a long conversation with this eminent astronomer and naturalist, who died the year after. He had just returned from a geographical and geological survey of the Far West, and higher parts of the valley of the Mississippi and Missouri. He showed me the ammonites, baculites, and other chalk fossils brought by him from those distant regions, which establish the wide range of that peculiar assemblage of organic remains characteristic of the cretaceous era.

From the deck of our steam-boat on the Potomac we saw Mount Vernon, formerly the plantation of General 
Washington. Instead of exhibiting, like the farms in the northern States, a lively picture of progress and improvement, this property was described to me by all as worn out, and of less value now than in the days of its illustrious owner. The bears and wolves, they say, are actually re-entering their ancient haunts, which would scarcely have happened if slavery had been abolished in Virginia.

The air was balmy on the Potomac the last day of January, and the winter had been so mild in the southern States, that we were surprised, on recrossing the Susquehanna at Havre de Grâce in Maryland, to see large masses of floating ice brought down from the Appalachian hills, and to feel the air sensibly cooled while we were ferried over the broad river. It struck me as a curious coincidence, and one not entirely accidental, that, precisely in this part of our journey, I once more saw the low grounds covered with huge boulders, reminding me how vast a territory in the South I had passed over without encountering a single erratic block. These far transported fragments of rock are decidedly a northern phenomenon, or belong to the colder latitudes of the globe, being rare and exceptional in warmer regions.

Pliladelphia, Feb. 1.- The newspapers are filled with accounts of the enthusiastic reception which Mr. Charles Dickens is meeting with every where. Such homage has never been paid to any foreigner since Lafayette visited the States. The honours may appear extravagant, but it is in the nature of popular enthusiasm to run into excess. I find that several of my American friends are less disposed than I am to sympathise with the movement, regarding it as more 
akin to lion-hunting than hero-worship. They express a doubt whether Walter Scott, had he visited the U. S., would have been so much idolised. Perhaps not ; for Scott's poems and romances were less extensively circulated amongst the millions than the tales of Dickens. There may be no precedent in Great Britain for a whole people thus unreservedly indulging their feelings of admiration for a favourite author; but if so, the Americans deserve the more credit for obeying their warm impulses. Of course, many who attend the foreigner's crowded levee are merely gratifying a vulgar curiosity by staring at an object of notoriety; but none but a very intelligent population could be thus carried away to flatter and applaud a man who has neither rank, wealth, nor power, who is not a military hero or a celebrated political character, but simply a writer of genius, whose pictures of men and manners, and whose works of fiction, have been here, as in his own country, an inexhaustible source of interest and amusement.

When at Philadelphia I was present at several meetings of the American Philosophical Society, and of the $\Lambda$ cademy of Natural Sciences. In the museum of the former body I was shown a limestone from Santas, in Brazil, procured by Captain Elliott, of the U. S. navy, which contains a human skull, teeth, and other bones, together with fragments of shells, some of them retaining a portion of their colour. The rock is less solid than that of Guadaloupe, which it resembles. We are informed, that the remains of several hundred other human skeletons, imbedded in a like calcareous tufa, were dug out at the same place, about the year 1827.* The soil covering the solid stone supported a growth of

* American Philosophical Transactions, 1828, p. 285. 
large trees, which covered the face of a hill on the side of the river Santas. The height above the sea is not mentioned, and it is to be regretted that the notes obtained by Dr. Meigs from Captain Elliott were not fuller. I observed serpulæ in the rock, a shell which the natives would not have carried inland for food. On the whole, therefore, I should infer, though we need further evidence, that this stone has emerged from the sea, and that there had been previously a submergence of dry land, perhaps the site of an Indian burial-ground.

Dr. Harlan, the zealous and accomplished osteologist, who, to my great regret, died the year after (1843), at New Orleans, took me to see the entire skeleton of the large fossil mastodon, or so-called Missourium, brought by Mr. Koch from the state of Missouri. He pointed out several errors in the manner in which the tusks and bones were put together. This splendid fossil has since been purchased by the British Museum, taken to pieces in London, and correctly set up again under the direction of Mr. Owen. It is the largest individual of the species (Mastodon giganteus) yet discovered; for Dr. Harlan and I compared the femur with that of the largest mastodon previously known, from the state of New York, and preserved in Peale's Museum in this city. The dimensions of the Philadelphia skeleton are less gigantic.

I spent six weeks very agreeably in this city, much of my time being occupied in delivering a short course of lectures on geology, and in comparing, with the friendly aid of several naturalists, especially Mr. Conrad, the fossils collected by me in the South with those previously known, most of which are preserved in the public and private cabinets here. Mr. Lea's collection of 
Chap. x.

shells, which we visited more than once, rich in the fluviatile species of North America, was most interesting to me. There seems no end to the freshwater mussels of the genus Unio, as well as other fluviatile forms, such as Melania, which have been created to people the waters of a continent unrivalled in the number of its rivers, all so copiously filled with water during every season of the year. Such an obvious relation of the zoological to the geographical peculiarities of a great region is striking, and reminds the geologist of the different states of the animal creation, which have accompanied the successive changes of the earth's surface in former ages. The same species of Unio, and of other fresh-water shells, preserved in a fossil state in alluvial strata, forming terraces one above the other to a considerable height above the Mississippi and its tributaries, show that the fauna here alluded to, so modern in the earth's history, is nevertheless of high antiquity, and has outlasted some important modifications in the shape of the valleys and levels of the North American streams.

We were taken to see the Penitentiary at Philadelphia, where all the prisoners are confined in separate cells. They see the keepers, chaplain, and occasional visiters, by which the rigour of their solitude is mitigated. They are taught to read, and have numerous occupations. If we recollect that this establishment is not an asylum for the poor, aged, and destitute, like our workhouses, but a place for the punishment and reform of criminals, we may regard it as a humane institution, and it appeared to me admirably managed. A few years ago, an American professor being asked at the end of a short stay in London whether he had 
been pleased with his reception, said he had been often invited out to dinner, but no one during his whole stay had offered him a seat in their pew in church. At Philadelphia, besides other kinds of hospitality, we had certainly no reason to complain of any want of attention in this respect, for we had pressing invitations to private pews in no less than six different Episcopal churches soon after our arrival, of which we availed ourselves on as many successive Sundays, and were struck with the handsome style of the buildings, and the comfortable fitting up of the pews. In regard to the preaching in these and in most of the Episcopalian, Presbyterian, Baptist, and Unitarian churches which I entered in the United States, I thought it good, and there seemed to me to be two great advantages at least in the voluntary principle: first, that the ministers are in no danger of going to sleep; and, secondly, that they concern themselves much less with politics than is the case with us. To be without a body of dissenters, dissatisfied with their exclusion from ecclesiastical endowments is a national blessing, which not only every statesman, but every churchman, will admit. I am by no means prepared to say whether there may not be a balance of evil in the voluntary system sufficient to outweigh the gain alluded to. While here, I heard complaints of the religious excitement into which the city had been just thrown by the arrival of a popular New England preacher, who attracted such crowds that at length all the sittings of his church were monopolized by the fair sex. American gallantry forbids that a woman should remain standing while gentlemen are comfortably seated in their pews, so that at last the men were totally excluded. Notice was immediately given 
that certain services were to be entirely reserved for the men, an announcement well calculated to provoke $\mathrm{cu}-$ riosity, and to tempt many a stray sheep from other folds. It was then thought expedient for the ministers of rival sects to redouble their zeal, that they might not be left behind in the race, and even the sober Episcopalians, though highly disapproving of the movement, increased the number of their services; so that I was assured it would be possible for the same individual between the hours of seven o'clock in the morning and nine in the evening, to go seven times to church in one day. The consequences are too like those occasionally experienced in the "old country," where enthusiasm is not kindled by so much free competition, to be worth dwelling upon. Every day added new recruits to a host of ascetic devotees, and places of public amusement were nearly deserted; at last even the innocent indulgence of social intercourse was not deemed blameless : and the men who had generally escaped the contagion in the midst of their professional avocations, found a gloom cast over society or over their domestic circle. The young ladies, in particular, having abundance of leisure, were filled with a lively sense of their own exceeding wickedness, and the sins of their parents and guardians.

Nany of the most respectable Quaker families have recently joined the Episcopal church, which is very flourishing here, not only in this city, but in the United States generally, having quadrupled its numbers in a period during which the population of the Union has only doubled. It is true that immediately after the revolutionary war, when this form of worship was identified with royalist opinions, and when not a few of its 
professors left the country for Canada, Nova Scotia, or the mother country, the Episcopal establishment was depressed below its natural level. Its revival and rapid progress are nevertheless remarkable in this republican country, and are perhaps partly owing to the possession of large endowments, especially in the State of New York, rendering it less dependent on voluntary contributions, and partly to the better station of the foreign immigrants from Great Britain belonging to the Anglican church.

I am assured, that if the salaries paid to the whole clergy of all sects in the Union are compared to those of the ministers of any other church in the world they will be found to be in excess in proportion to the population. Whether this be true or not, there is certainly no lack of divinity schools, nor of ecclesiastical buildings, nor of crowded congregations, the men being as regular in their attendance as the women; and the rapidity with which new churches spring up in the wilderness is probably without example elsewhere.

A rare event, the death of a wealthy man of colour, took place during my stay here, and his funeral was attended not only by a crowd of persons of his own race, but also by many highly respectable white merchants, by whom he was held in high esteem. He had made his fortune as a sail-maker, and is said to have been worth, at one time, sixty thousand pounds, but to have lost a great part of his riches by lending money with more generosity than prudence. I was rejoicing that his colour had proved no impediment to his rising in the world, and that he had been allowed so much fair play as to succeed in over-topping the majority of his white competitors, when I learnt, on 
further inquiry, that, after giving an excellent education to his children, he had been made unhappy, by finding they must continue, in spite of all their advantages, to belong to an inferior caste. It appeared that, not long before his death, he had been especially mortified, because two of his sons had been refused a hearing at a public meeting, where they wished to speak on some subject connected with trade which concerned them.

In many states, the free blacks have votes, and exert their privileges at elections, yet there is not an instance of a single man of colour, although eligible by law, having been chosen a member of any state legislature. The schools for the coloured population at Boston are well managed, and the black children are said to show as much quickness in learning as the whites. To what extent their faculties might be developed as adults we have as yet no means of judging; for if their first efforts are coldly received, or treated with worse than indifference, as in the case of the young Philadelphians before alluded to, it is impossible that the higher kinds of excellence can be reached in literature, the learned professions, or in a political career. If any individual be gifted, with finer genius than the rest, his mind will be the more sensitive to discouragement, especially when it proceeds from a race whose real superiority over his coloured fellow-citizens, in their present condition, he of all others would be the first to appreciate. It is after many trials attended with success, and followed by willing praise and applause, that self-confidence and intellectual power are slowly acquired; and no well educated black has ever yet had an opportunity of 
ripening or displaying superior talents in this or any other civilised country. Canada and Ireland teach us how much time and how many generations are required for the blending together, on terms of perfect equality, both social and political, of two nations, the conquerors and the conquered, even where both are of the same race, and decidedly equal in their natural capacities, though differing in religion, manners, and language. But when, in the same community, we have two races so distinct in their physical peculiarities as to cause many naturalists, who have no desire to disparage the negro, to doubt whether both are of the same species, and started originally from the same stock; when one of these, found in Africa in a savage and unprogressive state, has been degraded, by those who first colonized North America, to the lowest place in the social scale-to expect, under such a combination of depressing circumstances, that, in half a century, and in a country where more than six-serenths of the race are still held in bondage, the newly-emancipated citizens should, under any form of government, attain at once a position of real equality, is a dream of the visionary philanthropist, whose impracticable schemes are more likely to injure than to forward a great cause.

In the West Indies, where circumstances are far more favourable to a fair experiment, we have found how much easier it is to put an end to slavery than to elevate the blacks to an equal standing with the whites in society, and in the management of public affairs. They are however advancing slowly; and, although we hear complaints of ,commercial losses, consequent on emancipation, and of exports of sugar 
and coffee falling off, there seems little doubt that the negro population, comprising the great bulk of the inhabitants, are better informed, better clothed, and happier, in their own way, than during the period when all were slaves. A gradual transfer of land is going on in Barbadoes, Jamaica, and other large islands, from the original proprietors to the negroes, who are abandoning the cultivation of sugar, and raising such crops and fruits of the earth as they can obtain with moderate labour. There has not been time to ascertain whether the freed men will ever have aspirations after that higher civilization, which distinguishes a few of the more advanced among the nations of western Europe ; but this problem has still to be solved with regard to the Chinese and many other large sections of the human family.

The near approach to universal suffrage in the United States appears to me one of the most serious obstacles, both to the disfranchisement of the slaves in the South, and to their obtaining, when freed, a proper station relatively to the whites. Wherever property confers the right of voting, the men of colour can at once be admitted without danger to an absolute equality of political rights, the more industrious alone becoming invested with privileges which are withheld from the indigent and most worthless of the dominant race. Such a recognition of rights not only raises the negroes in their opinion of themselves, but, what is of far more consequence, accustoms a portion of the other race to respect them. In the free states, we were often painfully reminded of the wide chasm which now separates the whites from the emancipated man of colour.

If there be any place where distinctions of birth, 
wealth, station, and race should be forgotten, it is the temple where the Christian precept is inculcated that all men are equal before God. On one occasion in New England, when we were attending the administration of the sacrament in an Episcopal church, we saw all the white communicants first come forward, and again retire to their pews, before any of the coloured people advanced, most of whom were as well dressed as ourselves, and some only a shade darker in complexion. In another Episcopal church in New York, the order and sanctity of the service was, for a moment, in danger of being disturbed because some of the whites had been accidentally omitted, so that they came to the altar after the coloured communicants. After a slight confusion, however, our feelings were relieved by the officiating minister proceeding and showing his resolution not to allow any interruption from this accident. I had no opportunity of witnessing the good example said to be set by the Roman Catholic clergy in prohibiting all invidious distinctions in their churches; but we know in Europe how much more the poor and the rich are mingled together indifferently in the performance of their devotions in Romanist churches than in most of the Anglo-protestant congregations.

The extent to which the Americans carry their repugnance to all association with the coloured race on equal terms remained to the last an enigma to me. They feel, for example, an insurmountable objection to sit down to the same table with a well-dressed, wellinformed, and well-educated man of colour, while the same persons would freely welcome one of their own race of meaner capacity and ruder manners to boon 
companionship. I have no doubt that if I remained here for some years I should imbibe the same feelings, and sympathise with what now appears to me an almost incomprehensible prejudice. If the repugnance arose from any physical causes, any natural antipathy of race, we should not see the rich Southerners employing black slaves to wait on their persons, prepare their food, nurse and suckle their white children, and live with them as mistresses. We should never see the black lady's maid sitting in the same carriage with her mistress, and supporting her when fatigued, and last, though not least, we should not meet with a numerous mixed breed springing up every where from the union of the two races.

We must seek then for other causes of so general and powerful a nature as to be capable of influencing almost equally the opinions of thirteen millions of men. We well know that the abolition of villeinage and serfdom has never enabled the immediate descendants of freed-men, however rich, talented, and individually meritorious, to intermarry and be received on a footing of perfect equality with the best families of their country, or with that class on which their fathers were recently dependent. If in Europe there had been some indelible mark of ancestral degradation, some livery, handed down indefinitely from one generation to another, like the colour of the African, there is no saying how long the most galling disabilities of the villein would have survived the total abolition by law of personal servitude. But, fortunately, in Western Europe, the slaves belonged to the same race as their masters, whereas, in the United States, the negro cannot throw 
off the livery which betrays to the remotest posterity the low condition of his forefathers.

There are Indian reservations, and I often asked why there should not be also negro reservations, or large territories set apart for free blacks, where they might form independent states or communities. It would be proper to select those districts where the climate is insalubrious to Europeans, but where the blacks are perfectly healthy. I was assured that no scheme could be more Utopian-that the negroes, if left to themselves, would abandon the cultivation of sugar, cotton, and all the crops most appropriate to such lands. All this I can conceive; but my friends went on to object that the negroes would soon sink into savage life, and make marauding expeditions beyond their frontier. I have no doubt that if the two parties were left without a powerful check, some attempt would soon be made at territorial encroachments, but it is easy to foresee which party would be the formidable aggressor. 


\section{CHAPTER XI.}

Philadelphia.-Financial Crisis.-Payment of State Dividends suspended.-General Distress and private Losses of the Americans. -Debt of Pennsylvania.-Public Worlss.-Direct Taxes.-Deficient Revenue.-Bad Faith and Confiscation.-Irresponsible $\boldsymbol{E} x$ ecutive.-Loan refused by European Capitalists in 1842.-Good Faith of Congress during the War of 1812-14.-Effects of Universal Suffrage.-Fraudulent Voting.-Aliens. - Solvency and good Faith of the Majority of the States.-Confidence of American Capitalists.-Reform of the Electoral Body.-General Progress of Society, and Prospects of the Republic.

Philadelphia, January to March, 1842.-WIsHING to borrow some books at a circulating library, I presented several dollar notes as a deposit. At home there might have been a ringing of coin upon the counter, to ascertain whether it was true or counterfeit; here the shopwoman referred to a small pamphlet, reedited "semi-monthly" called a "Detector," and containing an interminable list of banks in all parts of the Union, with information as to their present condition, whether solvent or not, and whether paying in specie, and adding a description of "spurious notes." After a slight hesitation, the perplexed librarian shook her head, and declaring her belief that my notes were as good as any others, said, if I would promise to take them back again on my return, and pay her in cash, I might have the volumes.

It often happened that when we offered to buy articles of small value in shops, or fruit in the market, the venders declined to have any dealings with us, unless 
we paid in specie. They remarked that their change might in a few days be worth more than our paper. Many farmers and gardeners are ceasing to bring their produce to market, although the crops are very abundant, and prices are rising higher and higher, as if the city was besieged. My American friends, anxious that I should not be a loser, examined all my dollar notes, and persuaded me, before I set out on my travels, to convert them into gold, at a discount of eight per cent. In less than four weeks after this transaction, there was a general return to cash payments, and the four banks by which the greater part of my paper had been issued, all failed.

A parallel might perhaps be found for a crash of this kind in the commercial and financial history of England, or at least in some of her colonies, Australia, for example, where the unbounded facility afforded to a new country of borrowing the superabundant capital of an old one, has caused a sudden rise in the value of lands, houses, and goods, and promoted the maddest speculations. But an event now occurred of a different and far more serious nature. One morning we were told that the Governor of Pennsylvania had come in great haste from Harrisburg, in consequence of the stoppage of one of the banks in the city, in which were lodged the funds intended for the payment of dividends on state bonds, due in a few days. On this emergency he endeavoured to persuade other banks to advance the money, but in vain ; such was the general alarm, and feeling of insecurity. The consequent necessity of a delay of payment was announced, and many native holders of stock expressed to me their fears, that although they might obtain the dividend then actually 
due, it might be long before they received another. At the same time they declared their conviction, that the resources of the State, if well managed, were ample; and that, if it depended on the more affluent merchants of Philadelphia, and the richer portion of the middle class generally, to impose and pay the taxes, the honour of Pennsylvania would not be compromised.

It was painful to witness the ruin and distress occasioned by this last blow, following, as it did, so many previous disasters. Men advanced in years, and retired from active life, after success in business, or at the bar, or after military service, too old to migrate with their families to the West, and begin the world again, are left destitute; many widows and single women have lost their all, and great numbers of the poorer classes are deprived of their savings. An erroneous notion prevails in England that the misery created by these bankruptcies is confined chiefly to foreigners, but, in fact, many of the poorest citizens of Pennsylvania, and of other States, had invested money in these securities. In 1844, or two years after my stay in Philadelphia, the Savings' Bank of New York presented a petition to the legislature at Harrisburg for a resumption of payment of dividends, in which it was stated that their bank then held 300,000 dollars, and had held 800,000 , but was obliged to sell 500,000 at a great depreciation, in order to pay the claimants, who were compelled by the distress of the times to withdraw their deposits.

The debt of Pennsylvania amounted to about $8,000,000 l$. sterling, nearly two thirds of which was held by British owners; and as a majority of these belonged to that party which always indulged the most 
sanguine hopes of the prospects of the American republic, and estimated most highly the private worth of the people and their capacity for self-government, they suffered doubly, being disappointed alike in their pecuniary speculations and their political views. It was natural, therefore, that a re-action of feeling should embitter their minds, and incline them to magnify and exaggerate the iniquity of that conduct which had at once impugned the soundness of their judgment, and inflicted a severe injury on their fortunes. Hence, not a few of them, confounding together the different States, have represented all the Americans as little better than swindlers, who, having defrauded Europe of many millions sterling, were enjoying tranquilly and with impunity the fruits of their knavery. The public works executed with foreign capital are supposed by many in England to yield a large profit on the outlay, which is not the case in any one of the delinquent States.

The loss or temporary suspension of the interest even of one third of the above-mentioned debt, in a country like Pennsylvania, where there is a small amount of capital to invest, and that belonging chiefly to persons incapable of exerting themselves to make money, a country where property is so much divided, and where such extensive failures had preceded this crisis, inflicts a far deeper wound on the happiness of the community, than the defalcation of a much larger sum in Great Britain would occasion.

When we inquire into the circumstances which have involved the Pennsylvanians in their present difficulties, we shall find that, disgraceful as their conduct has been, their iniquity is neither so great, nor the pros- 
pect of their affairs righting themselves so desperate, as might at first sight be supposed. Every holder of Pennsylvanian bonds is undoubtedly entitled to assume that "there's something rotten in the state of Denmark," and to observe to any traveller who extenuates the delinquency of the State, "the better you think of the people, the worse opinion you must entertain of their institutions." How, under a representative form of government, can such events occur in time of peace, and, moreover, in a state so wealthy, that an income tax of $1 \frac{1}{3}$ per cent. would yield the two milions of dollars required, ${ }^{*}$ and where the interest on the bonds was not usurious nor unusual in America-unless the majority of the electors be corrupt or grossly ignorant?

It appears that in the year 1831, when Pennsylvania borrowed a large sum for making railways and canals, she imposed direct taxes for seven years, for the express purpose of regularly paying the interest of her debt. It was hoped, from the experience of New York, that, at the expiration of that term of years, the public works would become sufficiently profitable to render it unnecessary to renew the tax. The inhabitants went on paying until the year 1836, when the government thought itself justified in remitting the burden, on being unexpectedly enriched by several large sums from various sources. In that year they received for granting a charter to the U. S. Bank of Pennsylvania 2,600,000 dollars, and 2,800,000 more for their share of monies which had accumulated in the treasury of the Federal Government, arising out of the sale of public lands, and then divided among the States. It was calculated that these funds would last for three years, and that the

* Tucker's Progress of the U. S. 1843, p. 210. 
public works would by that time yield a revenue sufficient to defray the interest of the sum laid out on executing them.

That the legislature should have seized the first opportunity of relieving their constituents from the direct taxes will astonish no one who has perused the printed paper of the tax-assessor in Pennsylvania, which every one is required to fill up. The necessity of ascertaining the means of persons possessed of small property renders the questions exceedingly minute and inquisitorial. From a variety of others, I extract the following:"What is the amount of your monies loaned on mortgage, and the debts due to you by solvent debtors?" "What interest do they pay?" "What shares do you hold in any bank or company in any other State?" "How many pleasure carriages do you keep?" "How many watches do you own?-are they gold or silver?" and so forth.

Soon after the ill-judged remission of this tax, a great combination of circumstances led to over-trading, and the most extravagant schemes of money-making. The United States' Bank, during its controversy with President Jackson, had accumulated a large amount of specie, and lent it out most lavishly and imprudently; and when it obtained its new charter from Pennsylvania, it again promoted loans of all kinds, which gave an inordinate stimulus to speculation. Some of the great London banks, at the same time, gave credit to a prodigious amount, often without sufficient caution; and when they were compelled to withdraw this credit suddenly, they had not time to distinguish which of their creditors were worthy of confidence. A great fire in New York, in 1835, had annihilated property to the 
value of six millions sterling. After the United States' Bank had ceased to be connected with the Federal Government, many other States, besides Pennsylvania, granted charters to banks, which led to an over-issue of notes, and a hot-bed forcing of trade throughout the Union. Then came, in 1839, the miserable expedient of authorizing banks to suspend cash payments, and in 1841, the stoppage of the great U. S. Bank of Pennsylvania, followed by a general panic and financial crisis.

It is necessary to reflect on these events, in order to understand how the insolvency of Pennsylvania was brought about; but no American writer or statesman of any character pretends to excuse or palliate the conduct of her legislature in 1839, 1840, and 1841. In these years, there was an actual excess in the ordinary expenditure of the State for the purposes of government and education, over the receipts from all sources of revenue, except the public works. The proceeds of these last were appropriated to the payment of the interest of the debt, for which they were lamentably insufficient. In what manner were these various deficits provided for? Not by the imposition of new burdens, but by borrowing, and adding annually to the public debt. The party in power shrank from the unpopularity of laying on new taxes; and the slight share of discredit incurred by them at the time, for this glaring act of bad faith, places in a strong light the mischief arising from the small power here confided to the executive.

The Governor tells the Houses that there is a deficiency in the revenue, and they are left to make the best of it, and appoint a committee of ways and means, composed usually of members very incompetent as 
financiers. It is for them to consider what is to be done; there is no experienced official Minister of Finance, no chancellor of the exchequer, whose duty it is to come forward with a budget, and declare, like the English minister in 1842 :- "Here is an income-tax, to which you must submit, or we resign." 'The jealousy on the part of the people, and their fears of the abuses of a strong executive, have induced them to circumscribe its powers so much, that they have virtually deprived it of all responsibility. In their attempt to avoid one evil, they have fallen into another as great, if not greater.

The resources of the country were so paralyzed in 1842 , amidst the general wreck, and crash of commercial houses and banks, that the suspension of the payment of one or two State dividends had become unavoidable; but the non-payment even of a fraction of the interest in 1843-4, during a period of reviving prosperity and sound currency, reflects no small disgrace on the people, or discredit on the nature of their institutions.

It appears that in the year 1841, before the regular payment of dividends was suspended, a new property tax was imposed, which came into play in 1842 , and yielded to the State 486,000 dollars ; and 558,000 more in 1843, and an additional sum in 1844, of 755,000 dollars. These returns being inadequate, a new tax was laid on in 1844, with more stringent regulations for enforcing its collection, and it is now expected (December, 1844) that the public creditor, whose arrears of unpaid dividends have, in the mean time, been funded, will receive his due. But how many bondholders have been already obliged to sell out, while 
others are dead and gone, so that restitution to all becomes impossible; and thus, to a certain extent, an irretrievable act of confiscation has been perpetrated!

Let us now consider how far these evils can be attributed to causes of so general, lasting, and deep-seated a nature, as to have justified the monied men of England and the Continent, in 1842, in the distrust manifested by them of the good faith of the whole Union. Such a want of confidence was displayed when the agent of the Federal Government failed to obtain in Europe a loan of a few millions sterling offered on very advantageous terms.

On referring to the history of the United States, during the present century, we find that in the course of the war of 1812-1814, the nation had incurred a debt about equal to that now owing (1844) by all the delinquent States. A proposal was twice made in Congress to discontinue the payment of dividends to the English creditors, on the ground that they were enemies. On both occasions, the proposal was rejected, as dishonest, and with marked expressions of disapprobation; at a time when direct taxes levied by the Federal Government pressed heavy on the people. The debt went on increasing after the close of the war, but was at length entirely paid off in 1835. These transactions raised the character of American securities throughout Europe; and the altered tone of feeling evinced in 1842 is the more remarkable, as it occurred in a time of profound peace, when there was no immediate anticipation of war, and when it was well known that between the years 1812 and 1842 , the wealth and territory of the confederacy had increased enormously, and the population more than doubled. In fact, the ad- 
vance in the number of the inhabitants in this short interval was from eight to eighteen millions; the excess alone amounting to more than the population of all England at the commencement of the present century.

It cannot be denied that the course of events during the thirty years above alluded to has afforded grounds of anxiety to those who admire republican institutions and to every well-wisher of the prosperity of the Union. They who would make a permanent investment of money in U. S. stock must anticipate the possibility of war, and of a consequent reduction of revenue from the customs. If it then became necessary to lay on direct taxes, we have to consider, whether a majority of all the citizens would be likely to evince as much repugnance to pay their dividends punctually to foreign and domestic creditors as the Pennsylvanians and Marylanders have recently shown. If it has required several years to rouse the electors of these ancient States to a sense of their duty and honour, would the consciences of the new settlers in ruder and less advanced communities, constituting a large portion of the Union, be more sensitive?

As politicians, no people are so prone to give way to groundless fears and despondency respecting the prospects of affairs in America as the English, partly because they know little of the condition of society there, and partly from their own well-founded conviction, that a near approach to universal suffrage at home would lead to anarchy and insecurity of property. To divide the land equally among all, to make an "equitable adjustment" of the national debt, or, in other words, to repudiate, are propositions gravely discussed at Chartist 
meetings, and even embodied in numerously signed petitions to parliament. The majority even of the democratic party in the U. S. would probably assent to the opinion, that in England, where there is so much actual want, where one tenth of the population, or $1,500,000$ persons, receive parochial relief, where education has made such slow progress among the poor, and where there is no outlet in the Far West, no safetyvalve for the escape of the redundant inhabitants, it would be most dangerous to entrast every adult male with the right of voting. Yet in America they think the experiment a safe one, or even contend that it has succeeded. But not a few of the opposite party, however inexpedient and useless they may think it to agitate the question, agree with the majority of European politicians in considering that it has lowered and de, teriorated the character of the electoral body.

It is undeniable that the rapidity with which the native population has multiplied throughout the Union, and still more the influx of aliens into every State, has had a tendency to cause the whole country to resemble a new colony, rather than an old and long-established nation. Not only many new Territories and States, but even some of the old ones, such as New York and Pennsylvania, contain so much unoccupied land that they are full of adventurers and speculators from other parts of America, and of new-comers from Europe, speaking different languages, often cherishing foreign prejudices, and disturbing the equilibrium of native parties, founded on broad and distinct views of home policy. I have already remarked, that, on the southern frontier of the State of New York (p. 59.), I saw the native forest yielding as fast to the axe of the new 
settler, as if we had penetrated to the Far West, or the back woods of Canada. When we turn to her northern confines, we learn from the Reports of the Geological Surveyors employed by government in 1837, and subsequent years, that in Essex County and elsewhere they had recourse to Indian guides in a pathless wilderness, encountered panthers and moose-deer, found the beaver still lingering in some streams, saw lakes before undescribed, and measured the height of mountains for the first time. During my short sojourn in the metropolis of that State, I witnessed, among other illustrations of the heterogeneous composition of its people, a grand Repeal demonstration, an endless procession of Irish parading the streets, with portraits of O'Connell emblazoned on their banners, and various mottoes, implying that their thoughts were occupied with party questions of British, not of American politics. A large number of these aliens have, contrary to old usage, been of late years invested with electoral rights; and candidates for places in the magistracy, or the legislature, are degraded by paying court to their sympathies and ignorant prejudices. This temptation is too strong to be resisted; for, small as may be their numbers when compared with the native voters, they often turn the scale in an election where the great constitutional parties are very nearly balanced.

In addition to some of these evils, Pennsylvania labours under the disadvantage of being jointly occupied by two races, those of British, and those of German extraction. The latter are spoken of by the Anglo-Americans as the Bœotians of the land. They appeared to me industrious and saving, very averse to speculation, but certainly wanting in that habit of 
identifying themselves with the acts of their government, which can alone give to the electors under a representative system a due sense of responsibility. Some of them talked of their public works as of commercial projects which had failed; and when I remarked that, unlike the English, whose debts were incurred by carrying on wars, they were at least reaping some advantage from their expenditure, they assured me I was mistaken - that such cheap and rapid means of locomotion were positively injurious, by facilitating migrations to the West, and preventing a country with a "sparse" population from filling up. For this reason, their lands had not risen in value as they ought to have done. They protested that they had always been opposed to railways and canals; and that for every useful line adopted, there was sure to be another unnecessary canal or railway made, in consequence of "log-rolling" in their legislature. The representatives, they say, of each section of the country, would only consent to vote money, if they could obtain a promise that an equal sum should be laid out in their own district, and to this end some new and uncalled-for scheme had to be invented. This kind of jobbing they compare to logrolling in the back settlements, where the thinly-scattered inhabitants assemble and run up a log-cabin in a single day for the new-comer, receiving, in their turn, some corresponding service, whenever the union of numbers is required.

From all I could learn, I felt inclined to believe, that as soon as these Germans were convinced that they really owed the money they would pay it. There are, however, a multitude of European immigrants who have recently been admitted to take part in the elec- 
tions by shortening the term of years required for naturalization. It is also notorious that, owing tothe neglect of registration, many aliens vote fraudulently, and others several times over at the same poll, in various disguises.

To those English politicians who are not accustomed to look with favouring eyes on democratic institutions in general, the task of reforming such abuses appears hopeless. By what eloquence, they ask, can we persuade an ignorant multitude to abdicate power, if we have once taken the false step of conferring sovereignty upon them? At every election they must become more and more demoralized. It is proverbially difficult for truth to reach the ears of kings, and what matters it whether the sovereign consist of one or of many individuals? The flattery of demagogues is not less gross and servile than that of courtiers in the palaces of princes. The candidates for popular favour, when appealing to the passions of the vulgar, their vanity, pride, and national jealousy, never administer their honied drugs in homœopathic doses. By what arts or powers of oratory can we hope to persuade the least educated portion of the community, when they have once obtained by their numbers a preponderating influence, that they ought to be disfranchised?-that the more wealthy citizens, who have leisure for study and reflection, will shrink from the ordeal of contested elections, if they must defer to vulgar prejudices, and coarser feelings; - in a word, that some must be content to break stones on the road and dig canals, instead of choosing lawgivers, and instructing them how to vote? Nothing is more easy than to draw so discouraging a picture of the dangers of universal suffrage, that we 
are led to despair of the republic, and deem it far more wonderful that Ohio should pay than that Mississippi should repudiate. But when we take a nearer view of recent events, and observe what is now going on in the U. S., we discover grounds for viewing their affairs in a very different and far more cheerful light. In the first place, touching financial matters, it is satisfactory to know that, when the Central Government failed, in 1842, to contract a loan in Europe, the American capitalists came forward without hesitation, and advanced the money on the terms which had been rejected. The new stock rose at once above par, and has since become saleable in Europe at a premium of 16 per cent. The Americans have, also, made large purchases, in the years 1843 and 1844, of the bonds of Ohio, Kentucky, Tennessee, and even Pennsylvania; and had there been more capital seeking investment in the $U$. S., their securities generally would have changed hands to a greater extent.

This confidence is not based on any principles of pure patriotism, but on cool calculation and a knowledge that all but nine out of twenty-nine States and Territories are either free from debt, or have been true to their engagements. The only State which has formally disowned or repudiated a portion of her debt, amounting to about one million sterling, is Mississippi. She does not deny having received the money, or a part of it, but has the effrontery to allege, as ground for non-payment, that her agents exceeded their powers, and defrauded her. Michigan, also, and Florida, have held language somewhat bordering on repudiation; but the other States in arrear have promised to pay, and some of them are exerting themselves in earnest to 
accomplish the object. Upon the whole, the interest of nearly half the money borrowed has been regularly paid; and when we recollect that no small part of it was lent to new and poor States or Territories, where society is still in a rude, half-formed, and migratory condition, and that the money lent rashly and incautiously was spent, as might have been expected, improvidently, we must view their delinquency with some indulgence, and assign a share, at least, of the blame to the lender.

The state of Ohio has always punctually discharged the interest of her debt by direct taxes imposed for that special purpose, although there has been a deficit from the beginning on the proceeds of her public works. She is of recent origin, and her growth has been more rank and luxuriant than that of any other State of the Union. An influx of illiterate Irish, Welsh, and Westphalian settlers, has tended to lower the educational qualifications of her electurs, considered as a whole; but she came of a good New-England stock, which, like the philosopher's stone, has converted much of her baser metal into gold.

Any foreigner who has hastily embraced the notion that a suffrage virtually universal must be incompatible in the U. S. with order, obedience to the laws, security of property, a high degree of civilization, and the most unimpeachable public credit, has only to make himself acquainted with the present condition of the New-Fingland States, especially Massachusetts, and he will feel satisfied that the charge may be refuted. It is a wholly different question whether so democratic a constitution is equally fitted for the exigencies of many other parts of the Union, where the mass of the 
people are less advanced in knowledge and wealth, where the force of public opinion and sympathy is checked, and the free communication of thought impeded, by distinctness of races and of language.

Although the political constitutions of the several States are all formed on one great model, there exists considerable diversity in the details of their organization. The qualifications of the electors and legislators are not the same in all, nor the modes of appointment or powers of the Executive. There seems, however, a nearer approach to uniformity, than can be consistent with the very different degrees of social advancement and mental cultivation to which these independent States have attained.

To defects and blemishes of this kind, the leading statesmen in America are not blind, and both the evils and their remedies are subjects of the freest discussion. In many of the newspapers, and in the monthly and quarterly journals of both parties, in public lectures and speeches at elections, we find, during the last three years, the conduct of repudiating or defaulting States unsparingly condemned. The most earnest appeals are made to the sense of justice and honour, to the religious feelings or national pride, of their hearers or readers; they also tell them that it is their interest to pay, and that, if they cannot be moved by higher motives, they should remember that "Honesty is the best policy." The frequency and earnestness of these exhortations sufficiently prove the conviction of the writers and orators that a reform may be brought about. The mischief that has occurred is sometimes adduced as a proof that education and habits of temperance, although they have made great progress during the last 
fifteen years, have not yet been carried far enough. A more strict registration of the electors for the sake of putting an end to fraudulent voting, and the exclusion of foreigners from the electoral body, by lengthening the term of naturalization, are measures warmly insisted upon by the party opposed to the extremes of democracy - a party which, so late as the year 1840 , obtained a majority in a presidential election, when two millions and a half of persons gave their votes. Sanguine hopes are entertained that the most respectable members of the democratic party will also join in effecting reforms in the electoral system so obviously desirable. It is not simply the fair fame and happiness of eighteen millions of souls which are at stake; for during the lifetime of thousands now taking part in public affairs, or before the close of the present century, the population of the U. S. will probably amount, even on a moderate estimate, to no less than eighty millions.**

* Tucker's Progress of the U. S., p. 106. 
ChAP. XII.

\section{CHAP'TER XII.}

New York City.-Geology.-Distribution of Erratic Blocks in Long Island.-Residence in New York.-Effects on Society of increased Intercourse of distant States.-Separation of the Capital and Metropolis. - Climate. - Geology of the Taconic Mountains.Stratum of Plumbago and Anthracite in the Mica Schist of Worcester.-Theory of its Origin.-Lectures for the Working Classes. -Fossil Foot-prints of Birds in Red Sandstone.-Mount Holyoke.

-Visit to the Island of Martha's Vineyard.-Fossil Walrus.Indiuns.

New York, March, 1842.-The island on which New York stands is composed of gneiss, as are the cliffs on the left bank of the Hudson, for many miles above. At Hoboken, on the opposite side of the river, cliffs are seen of serpentine, a rock which appears to be subordinate to the gneiss, as in many parts of Norway and Sweden. All these formations, as well as the syenite of Staten Island, correspond very closely with European rocks of the same order.

Long Island is about 130 miles in length, and the town of Brooklyn, on its western extremity, may be considered as a suburb of New York. This low island is every where covered with an enormous mass of drift or diluvium, and is the most southern point in the United States, where I saw large erratic blocks in great numbers. Fxcavations recently made in the Navy Yard at Brooklyn have exposed the boulder formation to the depth of thirty feet; the lowest portion there seen consisting of red clay and loam, with boulders of trap and sandstone, is evidently the detritus of the New 
Red Sandstone formation of New Jersey. This mass, in the sections where I observed it, was about eighteen feet thick, and rudely stratified. Above it lay an unstratified grey loam, partly of coarse and partly of fine materials, with boulders and angular blocks of gneiss, syenitic greenstone, and other crystalline rocks, dispersed at random through the loamy base, the whole being covered with loam eight feet thick. One angular block of gneiss, which I measured, was thirteen feet long, by nine in breadth, and five feet high, but masses still larger have been met with, and broken up by gunpowder. Mr. Redfield, who accompanied me to Brooklyn, suggested that the inferior red drift may have been accumulated first when the red sandstone of the neighbouring country was denuded, and that afterwards, when the land was submerged to a greater depth, and when the gneiss and hypogene mountains of the highlands alone protruded above the waters, the upper drift with its erratics may have been thrown down. I am well disposed to adopt this view, because it coincides with conclusions to which I was led by independent evidence, after examining the districts around Lakes Erie and Ontario, viz. that the drift was deposited during the successive submergence of a region which had been previously elevated and denuded, and which had already acquired its present leading geographical features and superficial configuration.

At South Brooklyn, I saw a fine example of stratified drift, consisting of beds of clay, sand, and gravel, which were contorted and folded as if by violent lateral pressure, while beds below of similar composition, and equally flexible, remained horizontal. These appearances, which exactly agree with those seen in the drift 
ChaP. XII.

of Scotland or the North of Europe, generally accord well with the theory which attributes the pressure to the stranding of ice islands, which, when they run aground, are known to push before them large mounds of shingle and sand, and must often alter greatly the arrangement of strata forming the upper part of shoals, or mud-banks and sand-banks in the sea, while the inferior portions of the same remain unmoved.

Mr. Mather, in his Report on the geology of this portion of New York, ${ }^{*}$ states an interesting fact in regard to the arrangement of the boulder formation on Long Island, which, as before mentioned, extends for about 130 miles east and west. At its eastern extremity the boulders are of such kinds of granite, gneiss, mica, slate, greenstone, and syenite, as may have come across the Sound from parts of Rhode Island, immediately to the north. Farther westward, opposite the mouth of the Connecticut River, they are of such varieties of gneiss and hornblende slate as correspond with the rocks of the region through which that river passes. Still farther west, or opposite New Haven, they consist of red sandstone and conglomerate, and the trap of that country ; and lastly, at the western end, adjoining the city of New York, we find serpentine, red sandstone, and various granitic and crystalline rocks, which have come from the district lying immediately to the north. This distribution of the travelled fragments will remind every geologist of the manner in which distinct sets of erratics are lodged on the Swiss Jura, each set, whether of granite, marble, or gneiss, answering in composition to those parts of the Alps which are nearest and immediately opposite, as if

* Report for 1837, p. 88. 
they had crossed the great valley of Switzerland, more than fifty miles broad, in a direction at right angles to its length. The Sound, which separates Long Island from the main land, is from five to twenty-five miles broad. The fragments have doubtless been transported by ice; but we must suppose them to have been floated by ice-islands in the sea, as there are no high mountains in this part of North America from which glaciers can have descended after the continent had acquired nearly its present shape and altitude.

We spent several weeks at New York, and soon found ourselves at home in the society of persons to some of whom we had letters of introduction from near relatives in England, and others whom we had met at distant places in the course of our tour. So many American citizens migrate from north to south for the sake of mild winters, or attendance on Congress, or the supreme courts of law at Washington, or congregate in large watering places during the summer, or have children or brothers settled in the Far West ; everywhere there is so much intercourse, personal or epistolary, between scientific and literary men in remote states, who have often received their university education far from home, that in each new city where we sojourn our American friends and acquaintances seem to know something of each other, and to belong to the same set in society. The territorial extent and political independence of the different States of the Union remind the traveller rather of the distinct nations of Europe than of the different counties of a single kingdom like England; but the population has spread so fast from certain centres, especially from New England, and the facilities of communication by railway and 
steam-boat are so great, and are always improving so rapidly, that the twenty-six republics of 1842 , having a population of seventeen millions, are more united, and belong more thoroughly to one nation, than did the thirteen States in 1776, when their numbers were only three millions. In spite of the continued decline of the federal authority, and the occasional conflict of commercial interests between the North and South, and the violent passions excited by the anti-slavery movement, the old colonial prejudices have been softening down from year to year, the English language, laws, and literature, have pervaded more and more the Dutch, German, and French settlements, and the danger of the dismemberment of the confederacy appears to all reflecting politicians less imminent now than formerly.

I dined with Mir. Astor, now far advanced in years, whose name is well known to the readers of Washington Irving's "Astoria." He informed me that he was about to found a large public library in New York, which $I$ rejoice to hear, as the scientific men and naturalists of this country can rarely afford to purchase expensive European works with numerous illustrations. I often regretted, during my short residence here, that the town of Albany, 150 miles distant, is destined, because it is the capital, to possess the splendid collection of minerals, rocks, and fossils obtained during the late government survey. The surveyors are now employed in arranging these treasures in a museum, which would have been far more useful and more frequently consulted if placed in the midst of this wealthy metropolis, having a population of 300,000 souls. Foreigners, indeed, who have only visited New York for commercial 
purposes, may imagine that all the inhabitants are exclusively engrossed with trade and money-making; but there is a college here, and many large and flourishing literary and scientific institutions. I received numerous invitations to deliver lectures on geology, but had scarcely time to finish one short course when I was reminded, by the breaking up of winter, that I could resume my operations in the field.

It was now the second week of April, and already the willows on "the Battery" were putting forth their yellowish-green leaves. The air was as warm as in an English summer, although a few days before the ground had been covered with snow. Such sudden changes are trying to many constitutions; and we are told that if we staid a second year in the United States we should feel the influence of the climate, and begin to lose that freshness of colour which marks the newlyarrived Englishman. The greater sallowness of complexion here is attributed to the want of humidity in the air; and we ought to congratulate ourselves that there is no lack of that ingredient in the atmosphere of Great Britain. We continue to be surprised at the clearness of the skies, and the number of fine days and bright star-light nights, on this side of the Atlantic.

April 12, 1842.-Left New York, and ascended the North River to Hudson City, to observe there the transition or Silurian slates and limestones. These rocks have undergone so much disturbance that I was unable to satisfy myself-perhaps from want of more time for observation-whether the alleged unconformability of the fossiliferous limestone to the black slate is real or only apparent, and owing to shifts in the position of the strata. From Hudson City I followed 
the line of the railway by Chester and Westfield, over what is called the Taconic range of mountains. They may be considered, geographically, as a continuation of the Green Mountains of Vermont; and they do not differ greatly in their geological structure, the predominant rocks being gneiss, mica schist, talcose slate, and crystalline limestone, the larger portion of which would in the ordinary nomenclature of geology be called primary. They have, however, been termed metamorphic, because in some of the associated slates traces of fucoids and vermiform bodies, called Nereites, have been discovered. Professors Hitchcock and H. D. Rogers have expressed an opinion, which appeared to me highly probable after a cursory examination of these hills, that they consist of altered Silurian strata. Dr. Emmons, on the other hand, contends that they are more ancient than the lowest sandstone of the oldest fossiliferous group of New York, -in a word, that they are sedimentary strata of an era anterior to the Silurian, in a metamorphic state. The order of arrangement of the masses, their mineral constituents and organic remains, are appealed to in support of this theory; and several sections are considered as proving that the most ancient sandstones of the New York series rest unconformably on the rocks in question, to which Dr. Emmons gives the name of the Taconic system. But the fossils are so few, and so analogous either to species found in the Silurian strata in the United States or in those now generaliy referred, like the Nereites (a species of annelides?), to the inferior division of that group in Great Britain, that the claim of this Taconic group to an independent place among the paleozoic formations seems still very questionable. 
I went afterwards to examine the mica schist of Worcester, in Massachusetts, to the east of the Taconic range and of the Connecticut River, and forty-five miles due west of Boston. I found, interstratified with the mica schist and associated clay-slate of this place, a regular bed of plumbaginous anthracite, or impure graphite, portions of which give a streak on paper like a lead pencil. It has been used for making pencils, while a part of the stratum has been worked for coal, but apparently without profit, as the mine is now abandoned. The mica schist contains garnets and asbestus, and is much impregnated with carbonaceous matter. I searched in vain for vegetable impressions in the plumbaginous anthracite, which was in part iridescent, like coal, and so much resembled some of the earthy anthracites which I soon afterwards saw on the borders of Massachusetts and Rhode Island, at Wrentham, Cumberland, Attleborough, and Mansfield, that I feel strongly inclined to believe that the Worcester beds, however crystalline they may be, are no other than carboniferous rocks in an altered or metamorphic state. At the various localities last mentioned I found in the carbonaceous slates accompanying the anthracite the most common coal plants, such as Pecopteris plumosa, Neuropteris flexuosa, Sphencphyllum, Calamites, \&c. Although the associated strata were not in a crystalline condition, they and the coal were occasionally traversed with veins of quartz, like the plumbaginous bed at Worcester; and there are many places in Rhode Island and Massachusetts, pointed out by Dr. C. T. Jackson and Professor Hitchcock, in which the carboniferous and old red sandstone rocks pass into mica schist, and other hypogene rocks, 
especially in the neighbourhood of masses of granite and syenite. In some cases the pebbles of the conglomerate remain distinct, while the shaly base has been turned into a well-characterised mica schist, of which I obtained specimens.

I have already mentioned (p. 72.) that in crossing from the west of the Alleghany mountains to the eastern portion of the Appalachian coal-field the volatile ingredients (oxygen, hydrogen, and nitrogen) of the original coal bear continually a smaller and smaller proportion to the carbon. In the specimens which I myself obtained from Pomeroy, Ohio, where the coal is bituminous, and where the strata are undisturbed, the quantity of gaseous matter has been found by my friend Dr. Percy to be in the proportion of 19 per cent., the rest being carbon and ash. 2dly. In the coal at Frostburg, in Maryland, in the midst of the Alleghany chain, where the strata have undergone but slight disturbance, the proportion of volatile matter was found to be $9 \frac{1}{2}$ per cent. 3dly. In the Pennsylvanian anthracite of the Lehigh and Mauch Chunk mines, before alluded to (p. 69.), the volatile ingredients are about 5 per cent.*

In the plumbaginous anthracite of Worcester the proportion of volatile matter is about 3 per cent., there being a slight trace of nitrogen. I conceive that a

* These results were obtained from an elaborate analysis made for me by the kindness of Dr. J. Percy of Birmingham, since the statement given at p. 72. was printed. They bear out the geological inferences, there referred to, of Professor H. D. Rogers; but it will be seen that the proportions of the chemical constituents differ greatly, the gaseous matter being only half the previously estimated quantity. For details of the analysis and manipulations, see Appendix to a paper by the author, in the Journal of Geol. Soc., London, No. II. 1845. 
more powerful action of those same plutonic causes (heat, and other subterranean agencies) which are capable of converting sedimentary into crystalline rocks may have expelled nearly all the gaseous ingredients from a stratum of coal or anthracite, and turned it into an impure plumbago, while the carboniferous grits and shales were changed into carbonaceous mica-schist, clay-slate, and quartzite. At Little Falls, on the Mohawk River, and elsewhere in the U. S., and at the Falls of Montmorency, and other places in Canada, I have seen the lowest Silurian strata resting unconformably on gneiss and other hypogene formations. But we ought not to be surprised on that account, if we find on the American continent, as in the Swiss Alps and other regions in Europe, strata containing plants of the coal-measures, or of still newer dates, which have acquired the hypogene or metamorphic structure. Near the Atlantic border of the United States, in particular, we should be prepared for such a discovery, for we know that those powerful movements which have given rise to the Appalachian chain, folding and dislocating the solid rocks for a breadth of 150 , and a length of more than 1000 miles, and the injection into the eastern portion of the chain, of igneous rocks of the trappean and plutonic order, are phenomena posterior in date to the deposition of the American carboniferous strata. During so long a series of subterranean changes as are implied by these disturbances it may well have happened that considerable masses of the coal-bearing, as well as of more ancient paleozoic strata, should have assumed a crystalline texture.

At a small New England town in the Taconic hills above mentioned I was getting some travelling in- 
structions at the bar of an inn, when a carpenter entered who had just finished his day's work, and asked what lecture would be given that evening. The reply was, Mr. N. on the Astronomy of the Middle Ages. He then inquired if it was gratis, and was answered in the negative, the price being twenty-five cents (or one shilling English); upon which he said he should go, and accordingly returned home to dress. It reflects no small credit on the national system of education in New England, that crowds of the labouring classes of both sexes should seek recreation, after the toils of the day are over, in listening to discourses of this kind. Among the most popular subjects of lectures which I saw announced in newspapers or placards in different towns and villages were 'Temperance, a cause which has made great progress of late years among Protestants as well as Catholics, and which began in the U. S. fifteen years before the corresponding movement in Great Britain; Phrenology, to the pretensions of which the Americans lend too credulous an ear; the History of the American Revolution; the Present State and Past History of China; Travels in the Holy Land; Meteorology, and a variety of other topics.

April 15.-Visited Professor Hitchcock at Amherst College, Massachusetts, by whom the geological survey of that State has been ably executed. He showed me several ridges and large rounded hillocks of transported materials, or "drift," north of Amherst, surrounding swamps, in precisely the same manner as those usually referred to the glacial period in Scotland and Northern Europe. They have been called "moraines". by some geologists ; but if we call in the agency 
of ice, as I am well disposed to do, we must attribute their accumulation to the melting of icebergs charged with fragments of gravel and rock, rather than to glaciers. Professor Hitchcock has, in fact, styled them iceberg moraines.

At Smith's Ferry, near Northampton, about eleven miles north of Springfield, I examined, in company with the Professor, the red sandstone on the banks of the Connecticut River, where the celebrated foot-prints of birds are beautifully exhibited. The rock consists of thin-bedded sandstone (New Red, Trias?) alternating with red coloured shale, some of the flags being distinctly ripple-marked. The dip of the layers, on which the Ornithichnites are imprinted in great abundance, varies from eleven to fifteen degrees. It is evident that in this place many superimposed beds must have been successively trodden upon, as different sets of footsteps are traceable through a thickness of sandstone exceeding ten feet. My companion also pointed out to me that some of the beds, exposed several yards down the river, and containing Ornithichnites, would, if prolonged, pass under those of the principal locality, and make the entire thickness throughout which the impressions prevail at intervals, perhaps, twenty or thirty feet. We cannot, therefore, explain these phenomena simply by supposing large sheets of mud to have been spread out by the tidal waters, as may be observed on the broad flats bordering the Bay of Fundy. These last, it is true, as will be shown in a future chapter, exhibit the recent foot-prints of birds, in many successive layers, for a depth of two or three inches; but I cannot conceive such markings to extend through a thickness of twenty-five feet without supposing a 
subsidence of the ground to have taken place from time to time during the deposition of the layers on which the birds walked. The tracks are too well defined and distinct to have been made under water: there are clear indications of joints in the different toes; and there is generally such a deviation from a straight line in any three prints following each other as is observable in the trifid marks which birds leave on the sands of the sea-coast. The birds must have been of various sizes, from that of a small sand-piper to bipeds larger than the ostrich; and it is highly interesting to remark how regularly the distance between the footsteps increases or diminishes in proportion to the size of the foot-marks. In some of the most diminutive, for example, they are no more than three inches apart, but in the case of the largest (Ornithichnites gigas) they are from four to six feet. The length of the foot in the huge species last mentioned is in some instances no less than nineteen inches. Its magnitude being nearly twofold that of the African ostrich, as estimated by the foot (ex pede Herculem), and the acknowledged antiquity of the rock, disinclined many naturalists to adopt the views of Professor Hitchcock, when he referred the markings to extinct birds; but the discovery of the bones of the Moa or Dinornis of New Zealand, described by Mr. Owen, proved the existence, at no remote period, of feathered bipeds nearly as gigantic, and reconciled the zoologist at least to the credibility of the fact, however marvellous.

The waters of the Connecticut being low, I had an opportunity of seeing a ledge of rock of red shale laid bare, on which were imprinted a single line of nine footsteps of Ornithichnites giganteus, turning alter- 
nately right and left, and separated from each other by intervals of about five feet. At one spot there was a space several yards square, where the entire surface of the shale was irregular and jagged, owing to the number of footsteps, not one of which could be traced distinctly, as when a flock of sheep have passed over a muddy road; but on withdrawing from this area the confusion gradually ceased, and the tracks became more and more distinct. The Professor informed me, that since he first announced his belief, in 1836, that these impressions were referable to birds, he had observed above two thousand foot-prints, probably made by nearly thirty distinct species, all indented on the upper surface of the strata, and only exhibiting casts in relief on the under side of the beds resting on such indented surfaces.

This sandstone is of much higher antiquity (see $\mathrm{p}$. 125.) than any formation in which fossil bones or other indications of birds have been detected in Europe. Still we have no ground for inferring from such facts that the feathered tribe made its first appearance in the western hemisphere at this period. It is too common a fallacy to fix the era of the first creation of each tribe of plants or animals, and even of animate beings in general, at the precise point where our present retrospective knowledge happens to stop. The discoveries in the Connecticut valley ought to teach us extreme caution in deducing general conclusions from mere negative evidence, especially when we infer the non-existence of land animals from the absence of their remains in contemporaneous marine strata.

On leaving Amherst for Springfield, we ascended Mount Holyoke, the lower part of which is formed of 
CHAP. XI. GEOLOGY OF MARTHA'S VINEYARD. 203

horizontal strata of red sandstone, while the summit is capped with a picturesque mass of basaltic greenstone. This hill has been isolated by denudation, and from its summit we enjoyed a fine view of the fertile plain of the winding Connecticut. On its flanks we gathered the blue Hepatica triloba, the Houstonia cerulea, a white saxifrage, the May flower, Epigaa repens, and several plants, which have been recently naturalised in British gardens.

Immediately after my arrival at Boston I set out (April 19th) to explore the island of Martha's Vineyard, off the south coast of Massachusetts. Travellers who made this excursion a few years ago complain of being jolted in a coach over deep ruts and huge stones: now, an excellent railway carried me rapidly to New Bedford on the coast, where a steam-boat was in readiness, so that, having started long after sunrise, I was landed on "the Vineyard," eighty miles distant from Boston, in time to traverse half the island, which is about 20 miles long from east to west, before sunset. Late in the evening I reached the lofty cliffs of Gayhead, more than 200 feet high, at the western end of the island, where the highly-inclined tertiary strata are gaily coloured, some consisting of bright red clays, others of white, yellow, and green sand, and some of black lignite. They have been compared, not unaptly, by Professor Hitchcock, to the tertiary beds of Alum Bay in the Isle of Wight, which they resemble in appearance, though not in age. I collected many fossils here, assisted by some resident Indians, who are very intelligent. The section is continuous for four fifths of a mile, the beds dipping to the N. E. at an angle of from $35^{\circ}$ to $50^{\circ}$, and in some places to $70^{\circ}$. Their 
204 GEOLOGY OF MARTHA'S VINEYARD. CHAP. XI.

entire thickness must be very great, exceeding 2000 feet. The clays predominate over the sands. In the black beds containing lignites coniferous wood is abundant, and amber is said to have been found. The organic remains prevail at intervals in various strata, but I extracted most of them from a bed of green sand $(b)$,

N.E.

Fig. 6.

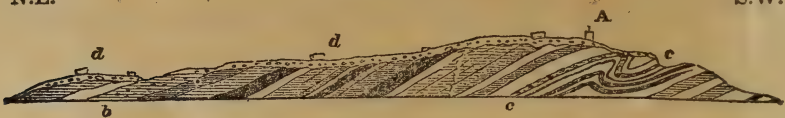

Section at Gayhead.

A. Lighthouse. $\quad$ b. Greensand with sharks' teeth.

c. Osseous conglomerate with walrus.

d. Drift.

near the north-eastern end. They consisted of casts of shells, teeth of large sharks, the vertebræ of a dolphin, and of a whale of great size. I also discovered a tooth referred by $\mathrm{Mr}$. Owen to the canine tooth of a seal.

Together with these, I found numerous nodules of the shape of kidney potatoes, from one to two inches in diameter, smooth externally, which I presume to have been coprolites. They have been analysed for me by my friend J. Middleton, Esq., F. G. S., and found to contain no less than 50 per cent. of phosphate of lime, the constitution of the latter being such as is peculiar to organic substances. They also consist of fluoride of calcium, chloride of sodium, and other elements. These coprolites, therefore, seem closely analogous in composition as in age, to those found by Professor Henslow in the Suffolk crag of Felixstow, and which accompany the bones of sharks and cetacea.

Near the lighthouse there is a great fold in the beds, where they are so bent as to have twice a northeasterly and once a south-westerly dip. One of these 


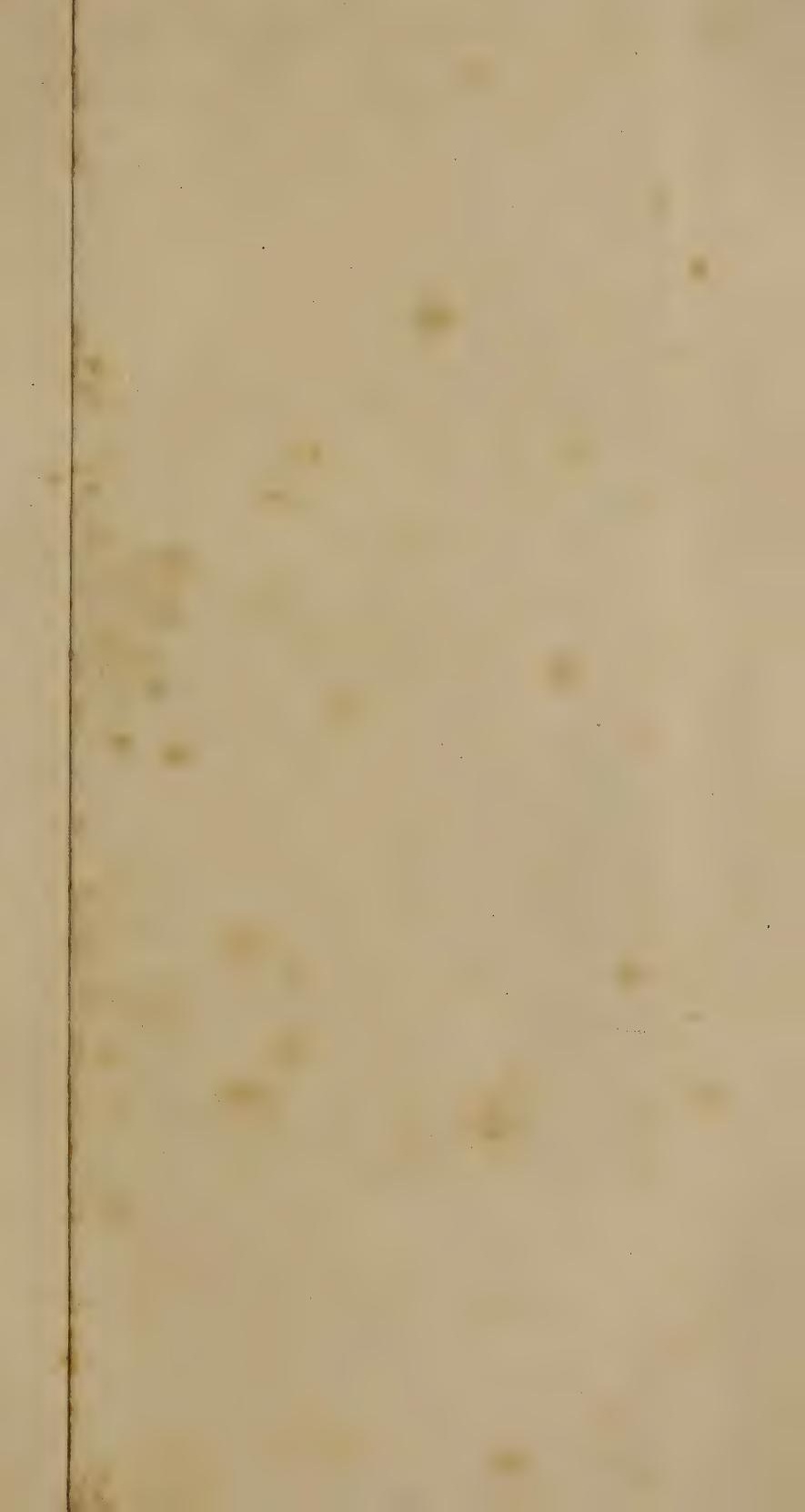




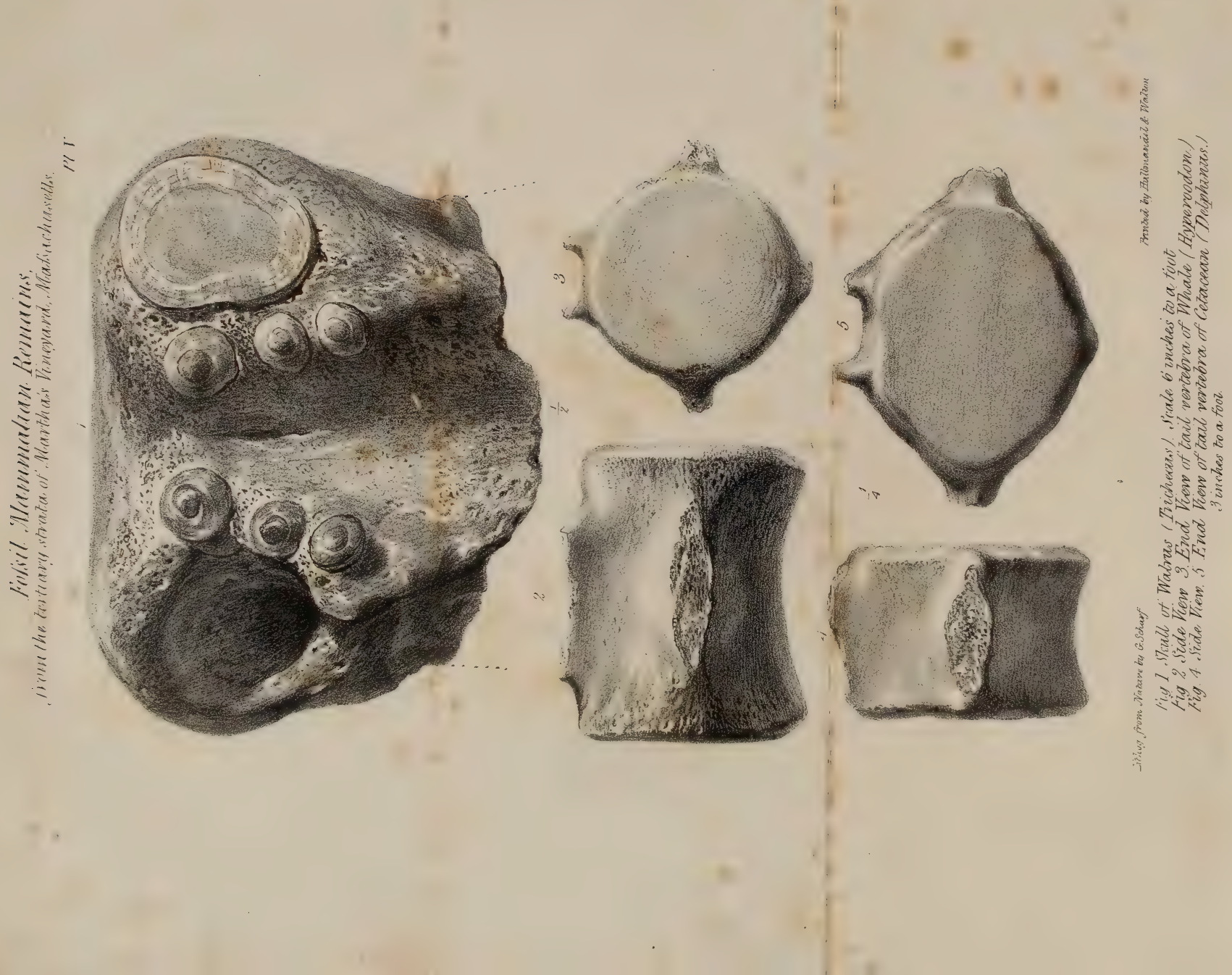


folded beds $(c)$ consists of an osseous conglomerate, in which I found several rolled cetaceous remains; and I purchased from a fisherman residing near the promontory a fossil skull: which he told me had fallen out of this conglomerate upon the beach below. It retained but a small portion of the original animal matter, was slightly rolled, and Mr. Owen recognised it as the cranium of a Walrus, or Morse, nearly allied to the existing species (Trichecus Rosmarus, Linn.). On comparison, it was observed to differ from it, in having six molar teeth, instead of four, on each side of the upper jaw. There are eleven specimens of the recent species in the College of Surgeons, in all of which there are no more than four grinders on each side. The tusk, also, of the Gayhead fossil has a rounder form than that of the recent Morse. (See plate V.)

Near Chilmark, on the S.W. side of the island, I found the same beds as at Gaybead, in a still more disturbed state. Upon the whole, the organic remains, especially the sharks' teeth, lead me decidedly to the opinion that the strata belong to a part of the tertiary series newer than the Eocene, to which they were formerly referred. They must be at least as modern as the Miocene marls of Virginia and Maryland, before described (p. 134). Several of the sharks' teeth are specifically identical with the fossils of those marls, and of the Faluns of Touraine and the Suffolk crag; and there are no greensands either of the Eocene or cretaceous periods in Martha's Vineyard, as some have conjectured. These conclusions, in regard to the modern date of this formation, are interesting, because, but for this small island, we should have had no evidence 
of the development of a great series of subterranean movements in this part of the American continent. The disturbances in question occurred between the Miocene epoch and the Boulder period; and we know not how far their influence may have extended over the hypogene rocks of New England.

The tertiary clays and sands of Martha's Vineyard are for the most part deeply buried beneath a mass of drift (d, Fig. 6.), in which lie huge erratic blocks of granite, often from twenty to thirty feet in diameter, which must have come from the North, probably from the mountains of New Hampshire. This covering of granitic detritus imparts to the soil a sterile character totally different from that which would naturally belong to the tertiary clays and marls.

I alluded to some Indians settled near Gayhead, a remnant of the aborigines, who have been protected by the Government of Massachusetts, all sales of land by them to the whites being null and void by law. They make excellent sailors in the whale-fishery of the South Seas, a source of great wealth to the inhabitants of "the Vineyard," and of New Bedford on the main land. That occupation, with all its privations and dangers, seems admirably suited to the bodily constitution and hereditary instinct of a hunter tribe, to whom steady and continuous labour is irksome and injurious.

The history of the extermination of the aboriginal Indians of New England is a melancholy tale, especially after so many successful exertions had been made to educate and christianize them. When at Harvard College, a copy of the Bible was shown me by Mr. Jared Sparks, translated by the missionary Father 
Elliott into the Indian tongue. It is now a dead language, although preached for several generations to crowded congregations.

On my return across the Vineyard from Gayhead I saw several spotted tortoises with red heads migrating from one pond of fresh water to another. On the seashore another novelty attracted my notice-several large specimens of the King Crab (Limulus polyphemus) were crawling about in the salt-water pools left by the sea on the retiring of the tide. 


\section{CHAP'TER XIII.}

Meeting of Association of American Geologists at Boston.-Populan Libraries in New England.-Large Sale of Literary Works ir the United States.-American Universities.-Harvard College. near Boston.-English Universities.-Peculiarities of their Sys. tem.-Historical Sketch of the Causes of these Peculiarities not of Medieval Origin.-Collegiate Corporations.-Their altered Relation to the English Universities after the Reformation.-Constitution given to Oxford by Leicester and Laud.-System of Public Teaching, how superseded by the Collegiate. -Effects of the Change.-Oxford Examination Statute of 1800.-Its subsequent Modificution and Results.-Rise of Private Tutors at Oxford and Cambridge.-Consequences of this Innovation.-Struggle at Oxford in 1839 to restore the Professorial System.-Causes of its Rejection.-Tractarianism.-Supremacy of Ecclesiastics.-Youthful Examiners.-Cambridge.-Advocacy of the System followed there--Influence of the English Academical Plan on the Cultivation of the Physical Sciences, and all Branches of Progressive Knowledge.-Remedies and Reforms.

April 25.-I returned to Boston to attend the third annual meeting of the Association of American Geologists, who had held their previous meetings of 1840 and 1841 at Philadelphia. On the present occasion Dr. Morton took the chair, and in the course of the week papers were read and freely discussed on a variety of scientific questions by many of the leading American geologists, some of whom had come from distant parts of the Union. The patronage afforded by the state surveys has created a numerous class both of practised observers and able writers. Among those engaged in these government undertakings, who took 
part in these proceedings, I may mention Professor Hitchcock, of Massachusetts, Professor W. B. Rogers, of Virginia, Professor H. D. Rogers, of Pennsylvania, Mr. Vanuxem, Dr. Emmons, Mr. Hall, and Dr. Beck -all engaged on the survey of New York; Dr. Jackson, who has surveyed Rhode Island, New Hampshire, and Maine; and Dr. Locke, of Ohio. There were also present Professor Silliman and his son, Messrs. Nicollet, Redfield, Gould, Bailey, Dana, Couthouy, Haldeman, Hubbard, J. L. Hayes, and others, all known as authors or contributors to scientific publications. The structure of the Alleghany Hills, and of the coal-fields of America, the origin of coral reefs, the glacial theory, the effects of icebergs, the nature of the foot-marks in the red sandstone of Connecticut valley, and other subjects, were debated upon during the week, in an animated but most amicable style. The citizens of Boston, learning that means were wanting for the publication of a series of valuable memoirs, read at this and former meetings of the association, came forward with their usual liberality, and supplied funds, by aid of which a volume entitled "Transactions of the Association of American Geologists for 1840-42," a work reflecting the highest credit on the cultivators of geology and its kindred sciences in America, made its appearance soon afterwards.

Munificent bequests and donations for public purposes, whether charitable or educational, form a striking feature in the modern history of the United States, and especially of New England. Not only is it common for rich capitalists to leave by will a portion of their fortune towards the endowment of national institutions, but individuals during their lifetime make 
magnificent grants of money for the same objects. There is here no compulsory law for the equal partition of property among children, as in France, and, on the other hand, no custom of entail or primogeniture, as in England, so that the affluent feel themselves at liberty to share their wealth between their kindred and the public; it being impossible to found a family, and parents having frequently the happiness of seeing all their children well provided for and independent long before their death. I have seen a list of bequests and donations made during the last thirty years, for the benefit of religious, charitable, and literary institutions, in the State of Massachusetts alone, and they amounted to no less a sum than six millions of dollars, or more than a million sterling.

There are popular libraries in almost every village of Massachusetts, and a growing taste for the reading of good books is attested by the sale of large editions of such works as Herschel's Natural Philosophy, Washington Irving's Columbus, and Plutarch's Lives. Of each of these, from five to twenty thousand copies have been sold. It will seem still more remarkable, that no less than sixteen thousand copies have been purchased of Johnes's Translation of Froissart's Chronicles, illustrated by wood-engravings, and twelve thousand of Liebig's Animal Chemistry. These editions were very cheap, as there was no author's copyright; but it is still more surprising, that about four thousand copies of Prescott's Mexico should have been sold in one year in the U. S. at the price of six dollars, or about twentysix shillings. When, in addition to these signs of the times, we remember the grants before alluded to, of the New England and other states in behalf of public 
schools and scientific surveys, we may indulge very sanguine hopes of the future progress of this country towards a high standard of general civilization.

The universities of the United States are annually increasing in number, and their discipline in New England (to which my inquiries on this head were chiefly confined) is very strict; a full staff of professors, with their assistants or tutors, superintending at once the moral conduct and intellectual culture of the students. In each university, there is a divinity-school, appropriated to some particular religious denomination, which is Presbyterian or Independent at New Haven, in Connecticut, where there are about six hundred students; and Unitarian at Harvard College, near Boston, where there are about four hundred. But youths belonging to various sects resort indifferently to New Haven, Harvard, and other colleges, to pursue their ordinary academical studies. After obtaining their first degree, they enter, if intended for the ministry, some theological faculty established in the same or in another university, or constituting a separate institution for the professional training of future divines. The Episcopalians have a flourishing college of this kind in the State of New York. The Independents, or Congregationalists, have one at Andover in Massachusetts, where a distinguished professor of biblical learning has been known to draw Episcopalians and students of other sects to his lectures, no persons being excluded, by subscription to articles of religion, from entering and studying in any college.

The multiplication of academical establishments, in consequence of every State, and every sect of Christians in each State, being ambitious of having schools 
of their own, is an evil, but one which would be greatly aggravated were the general as well as the theological education in the universities alike sectarian; or if students of classical literature, mathematics, law, and medicine, all required teachers who agreed with them in every article of faith. It has been remarked, by a living satirist, that the force of sectarian animosity, like that of gravity, increases inversely as the squares of the distance; but, in spite of the occasional ebullition in recent times of an intolerant spirit on both sides of the Atlantic, there are many auspicious signs of the approach of an era when differences of religious opinion will less interfere with national systems of education, both in schools and colleges. The present state of academical affairs in Scotland will perhaps be thought inconsistent with this view, where one party has been endeavouring to expel from the universities all professors who favour "free church" opinions, while the seceders from the establishment, not satisfied with a new divinity-school, have aimed at a new university for general instruction. There is now reason, however, to hope that the last-mentioned project will fail. There are already too many academical institutions in Scotland, in proportion to the means of adequately remunerating the professors; and their farther impoverishment, by the withdrawal of students from them to a new college, would be an injury to science and civilisation. The policy of the government in 1836 , when an attempt was made to unite King's and Marischal Colleges at Aberdeen, was wise and statesmantike, but it was baffled by the local jealousies of the two ancient rivals. Every effort should now be made to confine the new academical foundation to the faculty of theol- 
ogy ; and, for the same reason, to prevent the establishment of rival parochial schools, for the existing parish schools are often at present inadequately supported. It is deplorable enough to be compelled to admit the necessity of any new academical establishment, when we reflect that there is absolutely no difference of doctrine between the new rival churches in Scotland; and that the points of dissent have been deemed for a century and a half of such subordinate importance, as not to afford justifiable grounds for an open breach. In the Irish College at Belfast, endowed by government, a professor of Greek of acknowledged ability, nominated originally by the crown, with the approbation of the Presbyterians, has suddenly been deprived of the greater part of his class in consequence of the "free church" movement, although no blame is imputed to him on the score of a proselytising spirit, or of a wish to inculcate his own religious views. In the midst of these and other discouraging circumstances, it is satisfactory to observe, that three out of the five Scotch universities have recently declared to Parliament their desire that the religious tests which now shackle them and impair their efficacy may be removed.

In no subject do the Americans display more earnestness than in their desire to improve their system of education, both elementary and academical. They have sent missionaries to Europe, who have published elaborate reports on the methods of teaching now employed in Britain, Germany, Holland, and France, and they seem ready to adopt whatever appears worthy of imitation in these different models. The great diffculty under which they labour, and one inevitable in a new country, and common to them and the British 
American colonies, is the early age at which young men quit college, sooner by at least two years than in England.

In Harvard College, Cambridge, near Boston, the best endowed university in the United States, there are thirty-two professors, each assisted by one or more tutors. Many of them are well known in the literary world as authors. Five only of the thirty-two were educated for the pulpit, three of whom are professors of divinity, one of ethics, and one of history. All the students are required to attend divine service in the churches to which they severally belong, but the divinity-school for professional education is Unitarian. The pupils are examined in the New Testament, also in Paley's "Evidences," and Butler's "Analogy." The proportion of professors to students (about 400 in number) is far greater than that of college tutors in the English universities. The tutors of Harvard College may be compared, in some degree, to our private tutors, except that they are more under the direction of the professors, being selected by them from among the graduates, as the best scholars, and each is specially devoted to some one department of learning. These tutors, from whose number the professors are very commonly chosen, usually teach the freshmen, or firstyear students, or prepare pupils for the professors' lectures. Care is also bestowed on the classification of the young men, according to their acquirements, talents, and tastes. To accomplish this object, the student, on entering, may offer to undergo an examination, and, if he succeeds, he may pass at once into the second, third, or fourth year's class, the intermediate steps being dispensed with; he may also choose cer- 
tain subjects of study, which are regarded as equivalents, or are exchangeable with others. Thus, in the four years of the regular academical course, a competent knowledge of Latin, Greek, and of various branches of mathematics, is exacted from all ; but, in regard to other subjects, such as moral philosophy, modern languages, chemistry, mineralogy, and geology, some of them may be substituted for others, at the option of the pupil. 'There are public examinations at the end of every term for awarding honours or ascertaining the proficiency of students; who, if they have been negligent, or put back into a previous year's class, the period of taking their degree being in that case deferred. Honours are obtainable for almost every subject taught by any professor; but emulation is not relied upon as the chief inducement for study. After passing an examination for the fourth year's class, the student can obtain the degree of Bachelor of Arts, and may enter the divinity, medical, or law schools.

Every inquiry into the present state of the universities in America drew forth from my informants, in return, many questions respecting Oxford and Cambridge. I was asked by professors of geology, chemistry, modern history, modern literature, and other branches of knowledge, why the classes for these subjects had recently fallen off in the English universities? was their decline to be ascribed to tractarianism, a form of religious doctrine which, they said, had been recently transplanted into the United States, and was growing vigorously in the new soil? I declared my conviction that the tractarian movement at Oxford had been rather one of the effects of the slow and gradual changes introduced in modern times into the system of 
instruction there, than the cause of the recent banishment from that seat of learning of many sciences formerly taught there. The more I endeavoured to explain the present state of our academical course of study, and the peculiar organisation of the corps of teachers to whom its superintendence is confided, the more strange it appeared to my New England friends ; and I myself became the more aware of its distinctive and anomalous character, when contrasted with the methods followed elsewhere. Many who have been educated, like myself, at Oxford, are ignorant of the system of education formerly acted upon in our English universities, and of the real nature or causes of the present state of things. I shall, therefure, attempt to give, in the remainder of this chapter, a brief account of the leading peculiarities of our former and present academical machinery, and to point out its inevitable consequence, the very limited range of studies which can be pursued, so long as things remain unaltered. I shall do this the more willingly, because I know that any information which may throw light on the subject will be equally interesting to my readers on both sides of the Atlantic.

It may awaken curiosity in those who have never made any inquiries into these matters, if I make one or two preliminary statements. In the first place, then, the mass of students or undergraduates at Oxford is divided into twenty-four separate communities or colleges, very unequal in number, the residents in each varying from 10 in the smaller to about 140 in the larger colleges, and the whole business of educating these separate sections of the youth is restricted to the tutors of the separate colleges. Consequently, two or three individuals, and occasionally a single instructor, 
may be called upon to give lectures in all the departments of human knowledge embraced in the academical course of four years. If the college be small, there is only occupation and salary sufficient to support one tutor; any attempt, therefore, to subdivide the different branches of learning and sciences among distinct teachers is abandoned. There is no opportunity for one wian to concentrate the powers of his mind on a single department of learning, to endeavour to enlarge its bounds, and carefully to form and direct the opinions of his pupil. In a few of the larger colleges, indeed, some rude approach to such a partition is made, so far as to sever the mathematical from the classical studies; but even then the tutors in each division, are often called upon, in the public examinations, to play their part in both departments. Thus, a single instructor gives lectures or examines in the writings of the Greek and Roman historians, philosophers, and poets, together with logic, the elements of mathematics, and theology.

For the benefit of my foreign readers, it may be as well to remark, that the scholars to be taught are nut boys between the ages of fourteen and eighteen, at which latter age the degree of Bachelor of Arts was very commonly conferred in the olden times at Oxford, but young men between eighteen and twenty-two, who, at the expiration of their academical course, usually quit college, and enter at once upon a profession, or into political life. In the next place, I may state, that the choice of teachers, to whom so arduous and ambitious a task is allotted, is by no means left open to free competition, like the professorships in most ancient and modern universities; but, on the contrary, 
is confined within very narrow bounds. The college tutors are selected from graduates who are on the foundation of their respective colleges, and who may have obtained their appointment originally, some because they happened to be founder's kin, or were educated at a particular school, others because they were born in a particular town, county, or diocese ; a few only being selected from merit, or as having distinguished themselves in examinations open to all candidates. This latter class, however, has, it is true, increased of late years. Most of these teachers forfeit their fellowships, and most probably with it their office of tutor, if they should marry, or if, after a certain number of years, they do not embrace the clerical profession. They also look to preferment in the Church, from their position in their college, so that they have every inducement to regard the business of teaching as a temporary calling, subordinate and subsidiary to another, of a different, and to them more advantageous and important, kind. Their office as instructors is, in short, a mere stepping-stone to something else; and they hope to gain their reward, not when they are superannuated, for then they would be unfit for highly responsible ecclesiastical duties, but when they are still in the prime of life. In fact, their promotion is so contrived, as at once to cut short the career of usefulness in which they may have hitherto distinguished themselves.

It will naturally be taken for granted, by those who have never investigated the history of the universities, that the restrictions and fetters above enumerated are all of monastic and medieval origin. The celibacy of the teachers, the almost entire monopoly of tuition by the clergy; seem clearly to point to a period more re- 
mote than the Reformation, and when the supremacy and exorbitant power of the church of Rome were still at their height. But nothing can be farther from the truth. On inquiry, we learn with surprise, that the original plan of education at Oxford and Cambridge, as in the other European universities, was public and common to the whole mass of students. The present system has been upheld by no blind veneration for ancient usages, nor by the conservative principle carried to excess. There has been no dread of innovation exhibited in modern times. The substitution of the collegiate for a more general university scheme of instruction is the result of a modern revolution, altogether subsequent to the era of the Reformation, and no small part of it is a creation of yesterday, devised at the close of the eighteenth, and only carried out since the commencement of the nineteenth, century.

In order to understand how the colleges, or a few private corporations, obtained their ascendency over our two great national institutions, it is necessary to revert to the history of those early ages when the European universities originated. It appears that there was often a prodigious concourse of students to those seats of learning where the public teachers acquired celebrity. We may refuse to credit some old chroniclers, who reckon the number at Oxford and elsewhere at ten, twenty, and even thirty thousand; but it is certain that the scholars were often so crowded together in small towns, as to be exposed to great hardships, owing to the exorbitant price demanded for board and lodging. Benevolent individuals, who commiserated the sufferings of the poorer students, were induced from time to time to found houses, where they 
might obtain accommodation, and sometimes board, free of expense. Those who were not on such foundations were required, whether graduates or undergraduates, to belong to some Hall, or Inn, the head of which was usually elected by the scholars, and approved of by the chancellor of the university, or his deputy. As a large part of the students were boys, corresponding in age to those now educated at our public schools, they were placed under the special guardianship of some tutor, who was expected to look to their orderly behaviour, their religious exercises, and even, as appears by the old statutes, to "see that they conformed to academical rules in regard to matters of external appearance, such as their clothes, boots, and hair." It was the duty of the head of each house to see that the tutors were fit for their office, and to take care that the pupils attended the lectures of the public readers, or Masters of Arts, who gave lectures in the Schools.

On the Continent, the houses founded for the support of indigent teachers and scholars were entirely subjected to the authorities of their respective universities; but in England several of the colleges were governed by private statutes, over which the university exercised no control. Hence they had often interests apart from those of the university and of the public; but for centuries they were few in number, there being only three colleges in Oxford in the fourteenth century; whereas there were three hundred halls, or licensed boarding-houses, each sustained by the private contributions of students. At length the Reformation worked suddenly a complete revolution in the relative position of the collegiate corporations and the academical body 
at large. The religious schism banished many students who did not acquiesce in the new opinions. The temper of Henry the Eighth was so capricious and uncertain, and the policy of his three immediate successors so contradictory, that it was difficult to know what was the religion by law established for the current year; still less possible to calculate what would be the statutable orthodoxy for the year ensuing. Reasonable fears were also entertained that, as the monastic property had been confiscated, the endowments of the universities might not long be spared, so that literature and the church were uninviting professions, whether for ambitious or conscientious men.* The halls, depending for their support on the confluence of students, were ruined, except a few which were connected with certain colleges. Land and houses fell in value in Oxford, so that the colleges were able to purchase considerable property from the inspoverished burghers for a trifling consideration. Four new colleges were established within half a century subsequent to the Reformation, and altogether six during the sixteenth century, some of which were built on the sites of suppressed monasteries, or on land obtained by grants from the crown, or purchased for an insignificant price. After this period, only one college was founded-in 1610 ; and three of the eight remaining halls changed into colleges, in 1610, 1702, and 1740 .

* For many details respecting the early constitution of the universities of Paris and Oxford, and the subsequent changes in the English Universities, see an article by Sir William Hamilton, Bart., who was educated at Oxford, and is now Professor of Logic in the University of Edinburgh, Edin. Review, No. xcvi., June, 1831. 
Originally few of the colleges admitted undergraduates not on the foundation; but they now opened their gates, and were able to include the whole academical population within their walls, by which they obtained a preponderating weight and influence. This power, however, might have been defeated, if the Earl of Leicester, chancellor of the university, had not obtained, in 1570, an exclusive right to institute new halls, which was afterwards by statute vested in his successors. As the chief magistrate acted usually in concert with the heads of colleges, it was henceforth easy for the colleges to prevent any new hall from interfering with their monopoly ; whereas, previously to 1570 , the establishment of a hall was easy, it being only required that a small number of scholars should hire a house, find caution for a year's rent, and choose for principal a graduate of respectable character. The chancellor, or his deputy, could not, in that case, refuse to sanction his appointment.

The new constitution, procured for the university by Leicester, was considerably modified under the chancellorship of Archbishop Laud, who raised the heads of houses to the rank of a public body, called the Hebdomadal Board, to whom the privilege was given of proposing new laws to the House of Convocation. To the latter, consisting of the doctors and the masters of arts, the supreme legislation was still left, but without the power of initiating any measures. The heads were, by the constitution of their colleges, almost all ecclesiastics, and chosen from among the fellows of their respective colleges. Their election was, therefore, subject to all the disabilities and restrictions imposed on the fellows by the caprice of the founder. 
Thus two new elements, the preponderating influence of clerical over lay rulers, and the fortuitous restrictions invented for the regulation of private corporations, entered suddenly, and as it were accidentally, into the legislative constitution of the university.

From this period, it was almost inevitable, that the predilections of men of one profession, and the private interests of certain corporate bodies, should modify, if not remodel, the whole academical system, and frequently prevail over interests of a more general and national character. Soon after the university had begun to recover from the shock of the Reformation, several new readerships and professorships were endowed by Laud, and several others in the next century, after his time, in aid of that system of public instruction in the schools, which had been conducted originally by certain Masters of Arts, who were required to read and expound different subjects. The teaching of the undergraduates was now, therefore, divided between the colleges and the public instructors appointed by the university. The latter would have regained their former ascendancy, if they had been supported by the Heads of houses, who were intrusted with the charge of watching over the observance of statutes, and all "scholastic improvements." But they (the Heads) no longer obliged the students to attend public lectures regularly; and they frequently allowed some of the professors to desist from lecturing altogether, which many of them, from indolence, and from finding their audiences fall off, were disposed to do, especially as their instructions were given gratis. Such was the ordinary custom in the old universities; but in later times it had been found that this arrangement was 
very defective, that the professors were negligent, and that the students undervalued what cost them nothing, so that fees were permitted to be exacted. In Oxford, however, the professors were supplanted, in respect to these fees, by the college tutor, to whom a large part of the business of education was thus gradually transferred. Had a different course been adopted, the professors, acquiring in many cases celebrity in their respective departments, and devoted permanently, and often enthusiastically, to the sciences they taught, would have married and settled for life in Oxford; they would have gained an ascendancy over the minds of the students and the younger graduates in convocation; and many of them would have acquired an European reputation. The colleges might naturally feel jealous of allowing the growth of such a counterpoise to the power with which they had been recently invested.

When the old machinery was thus falling into disuse, and before the plan of college tuition was fully organised, the academical discipline appears to have been extremely lax, and the provision for education defective in the extreme. It was often difficult to find a college tutor competent to undertake the office, and there was occasionally only one or two of the resident fellows willing to accept of it. Instead of these important places being open to a free and fair competition, we may say that they were often held by selfappointed teachers. A regulation was made, that all the undergraduates should lodge within the walls of some college, which had the effect of preventing students from freely selecting those tutors who had the highest reputation, as rooms within the walls were 
soon filled, and no overflow was allowed of pupils lodging in the town. The enforcement of this law was said to have been jealously watched by some colleges, which would otherwise have been all but deserted, towards the close of the last century. The numerous scholarships and other endowments of the university, the college livings, and the academical degrees required as qualifications for entering holy orders, rendered the university very independent of public opinion; and whether it taught nothing efficiently, or failed to accommodate its form of instruction to the progress and spirit of the age, it could never apprehend a serious diminution of students.

Occasionally, there were examinations and a revival of studious habits in a particular college, or some professor gave a popular course of lectures, and drew large audiences. Thus Bradley, the famous astronomer, delivered, between the years 1746 and 1760 , to a class of pupils averaging 57 in number, lectures on Natural Philosophy, not in Latin, as had been the old practice, but in English. But the general indolence of the instructors, and the idleness and dissipation of the young men, became so notorious and flagrant towards the close of the eighteenth century, that a reform was loudly called for, and the governing body became deeply impressed with a sense of its expediency. Many plans were devised for carrying it into effect. As the annual or terminal examinations in several colleges had been found most useful in maintaining orderly habits among the young men, it was proposed to improve the public examinations, which had become a mere form, and to compel every one to pass them before obtaining his degree of Bachelor of Arts. Honours 
were to be awarded to those who distinguished themselves.

It was now evident that the shape in which this new statute was framed would determine what studies should henceforth be encouraged or discouraged in the university. It was clearly pointed out, at the time, that all those subjects which could not lead to academical distinctions would be virtually proscribed ; and that the well-known maxim of our lawyers in the interpretation of statutes would hold good in this case, "De non apparentibus et de non existentibus eadem est ratio." Whatever science was omitted in the list of studies selected for the trial of strength would be henceforth not merely slighted, but virtually blotted out of the academical course. Academical honours were here no empty bubbles, but might be expected to lead to fellowships, tutorships, livings, and other solid advantages. If the Heads of Houses and Members of Convocation had been simply legislating for national objects, and had not been the representatives of private and collegiate interests, which were not always identical with those of the public, it would have been easy to devise a comprehensive system of examinations, consisting of several boards, to which the professors, as well as tutors, would have been appointed, in stricter accordance with the spirit, and even letter, of the old statutes, than the new law which was then enacted. But this might soon have altered entirely the relative position in which the college tutors now stood to the public readers and professors. The latter would soon have acquired greater consequence in convocation; and had such a measure been proposed by the Hebdomadal Board it would probably have been lost. Ac- 
Chap. xir. EXaminatron statute of 1800.

cordingly, it was soon found that the new examination statute of the year 1800 was to be worked by the college tutors, young men for the most part about thirty years of age; and such being the case, no one can deny that studies embracing the Greek and Roman writers on history, philosophy, poetry, logic, rhetoric, and ethics, besides Christian theology, and the elements of mathematics, was as extensive a range as was compatible with such an executive. If they erred, their error certainly consisted in enlarging the circle of subjects far beyond the capacity of the college tutor; be his talents ever so great. The legislators especially displayed discretion in excluding from the schools all the more progressive branches of knowledge; for, in order to be a safe guide in directing the opinions of a pupil, or teaching what is known in such branches, liable as they are to be modified from year to year, by new facts, discoveries, and investigations, the preceptor must have leisure to devote his mind exclusively to one subject.

The new statute did not pass without a severe struggle. The rector of Lincoln College, in particular, opposed it, as a measure that would extinguish all "thirst of knowledge." "There would henceforth," he said, "be no university at all, but a system of cramming and partial teaching, after which the student would go out into the world with a narrow mind and darker understanding."

The necessity, however, of preparing for the compulsory examination, before taking a degree, worked immediately a salutary change in the habits and moral conduct of the idler students. The more clever and ambitious amongst them began to be excited by the 
competition for honours; a marked improvement was soon apparent in academical discipline; the university gained in public favour, and the number of students increased. The classes even of some of the professors were strengthened; but this effect was of short duration. It was soon found that the honours awarded at the examinations led to fellowships and tutorships; and the honourable rivalry of many of the colleges induced them to throw open their fellowships and scholarships much more freely than formerly to candidates of the highest merit ; the standard of merit, however, being, for the most part, measured by the new examinations in the schools. New methods were from time to time invented for classifying the youths according to their intellectual qualifications. In 1807, students who distinguished themselves were arranged in two classes, in 1809 in three, and in 1826 in four. A preliminary examination, called the responsions, or "little go," was introduced at the end of the first two years, or in the middle of the student's residence at Oxford. The examinations for degrees were made more and more stringent, and emulation at length stimulated to so high a pitch, that health was often sacrificed in the effort to gain the prize. Useful habits of application were often acquired, but the system was not calculated to foster a love of knowledge for its own sake. To some there was even danger of injury both bodily and mental; for if they succeeded, they were tempted to believe that they had already achieved something great; if they failed, their abilities were underrated, both by themselves and their contemporaries.

Another important revolution now took place. As the business of education had previously passed from 
the public readers and professors to the college tutors, so the latter were now in no small degree superseded by the private tutors or "crammers." These were graduates chosen by the young men themselves, at an expense of $40 l$. or $50 l$. a year, to read with them, both in term-time and vacation, and prepare them for the examination. An Oxford tutor informed me that, in the years 1840 and 1841 , no less than 250 , or one fifth of the resident students, procured this kind of assistance, the aggregate surn paid by them amounting to more than $10,000 l$. a year ! These young teachers watch the examinations, are acquainted with the style of the questions, whether vivâ voce or on paper, and often with the peculiar views of the examiner. It is their business to prevent their pupil from wasting his strength on topics not likely to be adverted to, and often to enable him to get by rote answers to certain interrogatories. The students are frequently unable to obtain this aid from the college tutor, whose system of lecturing is more general, and who cannot direct his attention to the individual wants and capacities of every pupil. The undergraduates, therefore, may be required to attend, between ten and one o'clock, the lectures of the college tutors. The next two hours (from one to three) are generally occupied by the private tutors, comprising that portion of the day during which the professors are by statute required to lecture. At three o'clock, it is high time for the young men to seek recreation and exercise; so that all the youths, especially the cleverest ones, are so entirely absorbed in a routine of study connected with the examinations, that the professorial class-rooms must unavoidably be abandoned. Bachelors of arts, and other graduates, 
had been heretofore in the habit of attending public lectures; but most of them now became engrossed with the new and lucrative business of cramming.

We learn from Dr. Peacock, now Dean of Ely, for many years an eminent tutor at Trinity College, Cambridge, that in that university, also, a similar revolution took place nearly at the same time." "A large proportion," he says, "of all the students, industrious or idle, rich or poor, resort to private tutors, to whom they pay, on an average, about $40 l$. a year. These teachers," he continues, "are young and inexperienced, and not competent to convey enlarged views" to their pupils. The labour imposed on them is too absorbing and severe to allow of the simultaneous prosecution of original studies; and "this unhappy system has contributed, more than any other cause, to the very general, and, in some respects, just complaints, which have been made of late years, of the paucity of works of learning and research which had issued from the University of Cambridge."

And here I may observe, that it is often the boast of writers who extol our university system above that of other countries, that we promote liberal studies, and do not condescend to qualify students for a lucrative profession or trade. But what is the real fact? Do not the majority of the ablest students toil at Latin, Greek, and mathematics, with purely professional objects? Are they not preparing themselves for becoming private tutors, schoolmasters, and college-tutors; expecting to combine these avocations with fellowships, or with clerical duties? Are not the things they

* See his excellent work on the Statutes of the University of Cambridge, p. 156. 
learn regarded as the means of earning a livelihood, or what the Germans call "Brodstudien," in plain English, to "make the pot boil ?" That some students should be qualifying themselves at the university to become masters in our public schools is highly desirable; and it would be well if the station in society of the schoolmaster, apart from any adventitious aid derived from uniting with it the clerical function, ranked as high in England as it does in Germany and the New-England States; but why should not the utilitarianism of our universities comprehend equally, within the sphere of its educational training, those branches of general knowledge which are equally essential to the future statesman, divine, lawyer, physician, and men of other liberal callings?

I am aware that it may be said, in regard to "crammers," that, under every system, some kind of private tuition will be required, and it will be asked, whether the assistants, under a professorial plan of instruction, would not be equally kept back in the improvement of their own minds? Certainly not-they would divide themselves at once into as many sections as there are departments of study recognised in the public examinations. They would devote their minds steadily to subjects connected with theology, or with law, or medicine, or engineering, or literary criticism, or applied mathematics, or other branches. Occasionally they would lecture for the professor; who, if worthy of his charge, must advance with his science, and not be ignorant of new discoveries and theories. Like him, they could not remain stationary. They would aspire in due time to fill his place, or some chair in another university. Such private tutors, whether lay or clerical, 
would not be found, at the expiration of ten years of hard and painful labour, precisely at the point from which they set out immediately after taking their first degree.

In the year 1S39, a last and most vigorous attempt was made at Oxford to restore the functions of the professorial body, which had now become contracted within the narrowest limits. The professors of Experimental Philosophy, Comparative Anatomy, Chemistry, Mineralogy, Geology, Botany, Geometry, and Astronomy, many of them well known in the literary and scientific world, sent in a representation to the heads of Houses, in which they declared their inability to discharge the duties they had undertaken, notwithstanding their unabated zeal and devotion. They accompanied their petition with a printed statistical table, showing how the number of their classes had fallen off annually, during a period in which, as they truly observed, the branches of knowledge taught by them were rising in popular favour and importance. It appeared by their table, that the anatomy class had dwindled between the years 1819 and 1838 to less than half, and that of astronomy to one fifth of its original numbers. The same had happened to the class of chemistry, between 1822 and 1838, many others having declined in the like ratio. The petitioners observed that, if no change were made in the examination statute, their usefulness as professors was at an end.

A majority of the heads of Houses were favourable to a reform, and they consequently proposed a new examination statute, in which there was a provision requiring attendance on at least two series of professorial lectures, as a preliminary qualification for the bachelor 
of arts' degree. 'The subjects of the various professors' lectures were classified under two heads, and one course was to be selected by the student from each division. The professors were required to keep a register of attendance, and give certificates. Although a new board of examiners to bestow honorary distinctions was not part of this plan, the measure might eventually have led to this and other improvements.

But it was now too late-reform was beyond the power of the Hebdomadal Board. Several academical generations had grown up under the new order of things. The collegiate and private tutors were interested in opposing the new provisions, and they were accordingly rejected in convocation. Yet while they threw out that part of the proposed statute which would have gone far towards reviving the professorial chairs, they passed another part requiring the professors of Astronomy, Experimental Philosophy, Chemistry, Geology, Mineralogy, Anatomy, Botany, Medicine, Civil Law, English Law, Greek, Arabic, Sanscrit, Anglo-Saxon, Poetry, Modern History, and Political Economy, to deliver regular courses of lectures. They were, in fact, bound not only by ancient statutes to require the teachers above enumerated faithfully to discharge their duty, but in modern times, or since the examination statute of 1800 , they had sanctioned the foundation of new chairs, such as Experimental Philosophy, Mineralogy, Geology, Political Economy, and Sanscrit, and had accepted annual grants from the Crown to endow certain readerships. In homage, therefore, to the moral obligations they had incurred, not to render these new and old foundations nugatory, they continued to exact an outward conformity to the stat- 
utes, by enforcing the delivery of lectures, the efficiency of which they allowed other parts of their system entirely to defeat. Their conduct reminds us of the orders issued by Charles the Fifth to offer up prayers throughout Spain for the deliverance of the Pope, while he suffered his army to retain him prisoner in the Castle of St. Angelo.

It must not be inferred, however, from the preceding observations, that I assume that the majority of the members of Convocation are not men of high principle, and animated with a conscientious desire of discharging faithfully their public duties. They and their predecessors probably did not at any moment deliberately plan or avow to themselves the line of policy which they have followed out so systematically, and with so much unity of purpose. The judgment of each generation has been constantly biassed by the same disturbing causes (the collegiate and clerical interests), which, like a current steadily setting one way, has insensibly carried the whole academical body out of its true course. In conformity to these interests, the original constitution has been gradually modified, and the system, when changed, has formed the minds of the succeeding generation, preparing it for new innovations, all conceived in the same spirit. If any single individual can be charged with a deliberate purpose of altering, essentially, the ancient constitution of the university, it is probably Archbishop Laud.

The year 1839 was memorable in Europe for another event, tending to prove how unpropitious to the cultivation of the physical sciences is the ecclesiastical spirit, whenever it obtains an undue power of interference with academical institutions. In the year alluded to, 
the first "congress" of scientific men took place in Italy. It assembled at Pisa, under the auspices of the enlightened prince who now reigns in Tuscany. The Pope interdicted all the professors of his colleges of Rome and Bologna, many of whom were prepared to co-operate warmly with the new association, from attending it. The papal prohibition was continued at the subsequent meetings at Turin, Florence, Milan, and elsewhere. Nevertheless, the congress flourished, and, in spite of the Pontiff's opposition, drew together many of the most distinguished men from all parts of Europe, and of Italy, beyond the confines of the States of the Church. It has also given to the world five costly volumes of valuable scientific memoirs, which, but for such patronage, might have remained unpublished to this day.

Doubtless the vote of the Oxford Convocation in 1839 was influenced by various motives; among others, a conscientious contempt for that sham professorial system which the graduates had so long contrasted with a reality, in the form of compulsory tutorial lectures and examinations, leading to degrees, and often followed by fellowships, livings, prebendal stalls, and bishoprics. In addition to these causes, it has been very generally understood that many, both of the college and private tutors, were opposed to the cultivation of the physical sciences on principle, on account of their alleged irreligious tendency. No one who reads some of the articles written by men who were fellows or tutors at Oxford, in the British Critic, against the "British Association for the Promotion of Science," can wonder that such reports were credited, or that they provoked, from a prelate educated at Oxford, the remark that "men 
who entertain such fears seem to forget that the book of Nature and the book of Revelation were buth written by the same Author."

Men are prone to undervalue those branches of knowledge which are foreign to their own pursuits; and if physicians, or lawyers, or civil engineers, had usurped as decided an ascendency in the legislation of a university, as the clerical graduates have now acquired at Oxford, complaints as loud and well founded might have been heard, that a due share of attention was not bestowed on studies connected with theology. In this spirit, therefore, it was attempted to mix up religious instruction with the teaching of other subjects. By some tutors it was held desirable that all ethics, metaphysics, and philosophy should be "christianized."

The practice of taking up for the examinations for honours such works as Butler's Analogy and Sermons had been encouraged after the year 1830, when a statute had passed "that the philosophy of the ancients might be illustrated in the schools, 'ex neotericorum scriptis,' or by the writings of the moderns." This and other changes had opened the door for considerable modifications in the course of academical study, and had given a new turn to the thoughts of many of the most rising and talented young men. It should be remembered that the last ten years has been the era of the Tractarian movement at Oxford, and the active intellect of the university has been for the most part absorbed in theological controversy. He who aspired to honours was bound in prudence to consider that his young judge, the arbiter of his academical fate, might probably be an advocate of the views set forth in some one or more of the 'Tracts for the Times. He might 
be one who was fully impressed with the dogma that "ethics unconnected with the church is a fundamental fallacy;" that "man without the church has no right to educate man*;" that "youth is too apt to delight in the inductive, instead of the deductive, reasoning ;"- "to prefer novelty to antiquity," investigation to obedience to authority, \&c.

As an example of the deductive process, as applied to my own favourite science, by a college tutor and public examiner of this period, I may cite a passage from lectures delivered in the university at the era under consideration, and since published :-

"A geologist, deeply impressed with the mystery of

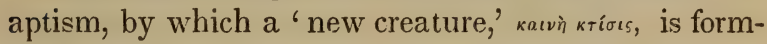
ed, by means of water and fire, would never have fallen into the absurdities of accounting for the formation of the globe solely by water or solely by fire. He would - not have maintained either a Vulcanian or a Neptunian theory." $\dagger$ The reader may well imagine, that, if other departments of science were "christianized" after the like fashion, the scholar might run some risk of emerging into the world, from his academical career, with his reasoning powers enfeebled, and his intellects mystified.

But to conclude our historical sketch. After the year 1839, we may consider three-fourths of the sciences, still nominally taught at Oxford, to have been virtually exiled from the University. The class rooms of the professors were some of them entirely, others nearly, deserted.-Chemistry and botany attracted, between the years 1840 and 1844, from three to seven students ;

* See Sewell's Christian Morals, ch. iv. and x.

+ Ibid. ch. xxii. 
geometry, astronomy, and experimental philosophy, scarcely more; mineralogy and geology, still taught by the same professor who, fifteen years before, had attracted crowded audiences, from ten to twelve; political economy still fewer; even ancient history and poetry scarcely commanded an audience; and, strange to say, in a country with whose destinies those of India are so closely bound up, the first of Asiatic scholars gave lectures to one or two pupils, and these might have been absent, had not the cherished hope of a Boden scholarship for Sanscrit induced them to attend.

As if to complete the cycle of change, and to cause the system to depart as widely as possible from the original university, which secured for the students the services of public and permanent teachers, men of mature age and acquirements, and often highly gifted, the Oxford tuition now fell, from year to year, into the hands of younger graduates, whether in the capacity of private tutors or examiners. Several causes had concurred to accelerate the promotion of college fellows. Their number was still the same, not having increased with church extension, and the multiplication of new schools in a growing populatlon. It consequently became so difficult in many colleges to choose for tutors, fellows who were not manifestly too young, that, to remedy the evil, several heads of Houses wisely permitted men who had forfeited their fellowship by marriage to continue as tutors. It would appear, from the Oxford Calendar for 1835, that no less than seven of the Colleges, and four of the Halls, have been driven to this resource. Nevertheless, the majority of the body of public examiners is often under the age of thirty, and some of them only twenty-five years old! They go out 
of office in succession, after serving for two years. On this fluctuating body of young men, responsible to no one for their decisions, whether in passing students for degrees, or in awarding honours, a body having the power of modifying at their caprice the whole style and tenour of the public examinations, the direction of academical education in this great country has practically devolved!

At Cambridge, the collegiate influence has, since the Reformation, caused the university to pass gradually through nearly all the same phases as at Oxford. Here, also, the transference of the business of instruction from the public and permanent to the collegiate and temporary teacher, has coincided precisely, in point of time, with greater strictness in the examinations, and more studious habits and better discipline among the undergraduates. It is natural that, owing to this coincidence, a false notion should be engendered, that the subdivision of labour amongst a well organized body of professors is less effective than the method of college tuition.

It might, perhaps, have been expected that such a subdivision would have been carried farther at Cambridge, in consequence of more than half the students being members of two, out of seventeen, colleges; namely, Trinity and St. John's. These noble foundations contain, each of them, from 400 to 500 undergraduates, and might almost be regarded, from their numerical strength, as universities of themselves. But although the fellowships in both of them are awarded to merit, the educational functions must be, comparatively speaking, of secondary importance to the fellowtutor; for, being almost invariably a clergyman, his 
highest hope of future preferment is not in the University, but in the Church. The proportion of students intending to take orders is not so large here as at $\mathrm{Ox}$ ford, and they are not required to subscribe, on matriculation, any formula of religious belief, so that Roman Catholics and dissenters from the Church of England can study here, and obtain academical honours, though not degrees. The responsible duty of conducting the public examinations is even here in the hands of very young men, though two of the mathematical professors assist in awarding the Smith's Prize, the highest mathematical honour; and the professor of Greek and the public orator, presumed to be a first-rate Latin scholar, preside in the examination for the Chancellor's medal for classics.

Very recently at Cambridge, all branches of knowledge taught by the professors-in a word, every subject except what is understood in our universities by classics and mathematics--have had sentence of banishment passed upon them in the form of new compulsory examinations, under the management of college tutors, the Oxford plan of awarding honours to classical and mathematical attainments alone being adhered to. The professors of chemistry and anatomy, who had formerly considerable classes, have only mustered six or seven pupils, although still compelled to give courses of fifty lectures each. The chairs of Modern History, and of the application of Machinery to the Arts, once numbering audiences of several hundreds, have been in like manner deserted. Yet dispensations are rarely granted for the discontinuance of useless duties, even when only two pupils present themselves. 
Moreover, here, as at Oxford, it is not uncommon to give such chairs as Mathematics, Natural Philosophy, Chemistry, Botany, Astronomy, Geology, Mineralogy, and others, to clergymen, who combine them with clerical duties, or throw them up when they obtain preferment, and who, however eminent, owing, as they must do, a mixed allegiance, partly to their ecclesiastical order, and partly to the professorial body, cannot stand up with heart and courage in defence of the public, as opposed to the clerical and collegiate, interests.

Dr. Whewell, now Master of Trinity, after many years' experience as a tutor at Cambridge, published, in 1837 , his views on the plan of education adopted in the English universities. His arguments in favour of employing the learned languages as a main instrument of education are unanswerable, and enforced with great eloquence and power. "In what a condition should we be," he observes, "if our connection with the past were snapped-if Greek and Latin were forgotten?"* No less cogent are his reasons for cultivating mathematics as a means of strengthening the reasoning powers and disciplining the mind. But when we come to that part of his treatise in which he attempts to defend the exclusive monopoly enjoyed by these subjects in the education of young men at Oxford and Cambridge, from the ages of eighteen to twenty-two, including a period at the end of which the majority of them quit college altogether, his commendations of the system appear to me rather to resemble the pleadings of an advocate, than those enlightened and philosophical views which characterise his works in general. Obedience and deference to authority are held forth as if

* Principles of University Education, London, 1837, ch. i. sect. 4. 
they were the chief and almost sole moral virtues to be instilled into the minds of young academicians. The students are treated more as boys and children than as men on the very point of entering on their several duties in life, and who ought, without loss of time, to be acquiring habits of thinking and judging for themselves.

"Mathematical doctrines are fixed and permanent," says the historian of the Inductive Sciences, of whose remarks on this subject $I$ shall give a brief abstract in his own words. "The old truths will always be true. In philosophical doctrines a constant change is going on. The old system is refuted, and a new one is erected. There is nothing old, nothing stable. The student cannot but suspect that his teacher and his teacher's creed are but for a day. The mind of a young man employed in attending to teachers of this kind must fail to acquire any steady conviction of the immutable and fixed nature of truth. $\mathrm{He}$ becomes a restless speculator, criticising what has already been done in philosophy, attempting to guess what will be the next step. He is placed in the condition of a critic instead of a pupil."- "In mathematics, the teacher is usually the superior of his scholar, who entertains a docile and confiding disposition towards his instructor. He cannot give or refuse his assent when a system is proposed to him, nor feel in the situation of an equal and a judge. The subjects suitable for university teaching are the undoubted truths of mathematics, and works of unquestioned excellence, such as the best classical authors. When engaged in these, the student respects his instructor; they are the fit subjects of college lectures. A spirit of criticism is awakened by the study 
of philosophy, which is a fit subject of professorial lectures."**

In commenting on the above passages, I cannot refrain from remarking, that if the teacher of philosophy cannot command the respect of his pupils, he must be ill-qualified for his post. No one who is master of his favourite science will fail to inspire the minds of his more intellectual scholars with a love of what he teaches, and a regard and admiration for their instructor. "Addicti jurare in verba magistri," they will be only too prone to prefer Plato to truth, and defend the professor's theory, even when he himself has seen reason to modify it in accordance with new facts and reasonings.

When we inquire by what kind of training young men can best be prepared, before leaving the university, to enter upon the study or practice of their professions, whether as lawyers, physicians, clergymen, schoolmas ters, tutors, or legislators, can we assent to the notion that, by confining instruction to pure mathematics, or the classical writers, more especially if the latter are not treated in a critical spirit, we shall accomplish this end? Do not these belong precisely to the class of subjects in which there is least danger of the student's going wrong, even if he engages in them at home and alone? Should it not be one of our chief objects to prepare him to form sound opinions in matters connected with moral, political, or physical science? Here, indeed, he needs the aid of a trustworthy guide and director, who shall teach him to weigh evidence, point out to him the steps by which truth has been gradually attained in the inductive philosophy, the caution to be

* University Education, pp. 46-53. 
used in collecting facts and drawing conclusions, the prejudices which are hostile to a fair inquiry, and who, while his pupil is interested in the works of the ancients, shall remind him that, as knowledge is progressive, he must avail himself of the latest acquisitions of his own age, in order to attain views more comprehensive and correct than those enjoyed even by predecessors of far superior capacity and genius.

It may appear strange, that while such great sacrifices of time are made in England to the exclusive cultivation of classics, a larger proportion of the best modern editions of Greek and Latin are not the fruit of British scholarship. The cause, however, is easily explained. The highest excellence in literature or in science can only result from a life perseveringly devoted to one department. Such unity of purpose and concentration of power is wholly inconsistent with our academical machinery of tuition.

The panegyrists, indeed, of the modern university system in England, seem never to admit candidly this plain truth, that the colleges have no alternative in regard to the course of study open to them. Take any flourishing university in Great Britain or on the Continent, Berlin, for example, or Bonn, or Edinburgh, where a wide range of sciences are taught. Let the students be divided into fifteen or more sections, without any classification in reference to their age, acquirements, talents, tastes, or future prospects. Assign to each section a separate set of teachers, chiefly clerical, and looking forward to preferment in the Church and public schools, and from them select all your public examiners. What must be the result? The immediate abandonment of three fourths of the sciences now 
taught, while those retained will belong of necessity to the less progressive branches of human knowledge. Under conditions so singular as those now imposed on Oxford and Cambridge, I am ready to join their warmest eulogists, and to contend that their plan of education is the best.

In the treatise on the universities, before alluded to, there are hints thrown out on the "ignoble influence of compulsory examinations, which act on the fears rather than on the hopes of young men," and which have "drawn off many students from professorial lectures ;" on "examiners not habitually pursuing particular studies, and whose knowledge, therefore, has no fulness, richness, depth, or variety ;" also on private tutors having no ostensible and responsible situation in the university, and the tendency of modern changes to throw the whole academical education into their hands and those of the public examiners (ibid.ch. ii.); which may lead us to infer that the optimism of the Master of Trinity is not of that uncompromising kind which should make us despair of his co-operation in all future academical reforms.

In considering the present state of feeling towards science and its cultivators in England, I cannot refrain from citing a passage (with the leave of both the correspondents) from a letter dated February, 1845, addressed by Professor Liebig to Mr. Faraday :-

"What struck me most in England was the perception that only those works that have a practical tendency awake attention, and command respect, while the purely scientific, which possess far greater merit, are almost unknown. And yet the latter are the proper and true source from which the others flow. Practice 
alone can never lead to the discovery of a truth or a principle. In Germany, it is quite the contrary. Here, in the eyes of scientific men, no value, or at least but a trifling one, is placed on the practical results. The enrichment of science is alone considered worthy of attention. I do not mean to say that this is better; for both nations the golden medium would certainly be a real good fortune."

What I have said of the method and course of instruction now pursued in our principal universities will, I think, explain in no small degree the prevalence of the utilitarian spirit, so correctly pointed out by this distinguished foreigner, and the want of a due appreciation of the higher and more difficult departments of philosophical research. From what source is the public at large, whether belonging to the upper or middle classes, to imbibe a respect and veneration for those who are engrossed in the pursuit of philosophical truth, and who live excluded from active life, if they who direct university education do not foster, nay, if they positively discourage, the teaching of the progressive sciences? How can the multitude learn, that, for one mind willing or capable of patiently working out and discovering a new truth or principle, there are hundreds who can apply to practice these principles, when once ascertained? Nothing can be more short-sighted, therefore, even on purely utilitarian grounds, than the usual policy of the herd of cui bono philosophers, who award higher honours and emoluments to the application than to the discovery of scientific principles.

It is truly fortunate that, in proportion as Oxford and Cambridge have withdrawn their countenance more and more from studies connected with physical science 
and natural history, the wants of a high state of civilization, and the spirit of the age, have afforded to them in England an annually increasing patronage. It is felt that astronomy is indispensable to navigation, chemistry to agriculture and various arts, geology to mining, botany to medicine, and so of other departments. If the practical connection of any branch of science be not obvious, as in the case of zoology, scarcely any encouragement is given to it in any English place of education; but even here, fortunately, the British Museum and the College of Surgeons, by their extensive collections, step in, and in some degree supply the deficiency.

After the rejection at Oxford of the moderate measure of reform proposed in 1839, for combining together the professorial and tutorial systems, we can scarcely hope that any movement from within will effect the changes so loudly called for. Time will, year after year, remove the older members of Convocation, who are favourable to more enlarged views, and will replace them, it must be feared, by the avowed partizans of the narrower system of study, adopted in more modern times, and under which they have been brought up. Appeal under such circumstances must therefore be made to an external authority. A royal commission like those which have more than once visited of late years the universities of Scotland, might prove a sufficient counterpoise to the power and vis inertice of forty learned corporations. They might suggest such remedies as the licensing of new Halls, the removal of tests on matriculation, the awardiug of honorary distinctions for proficiency in the subjects of the professorial lectures, and many others, which would doubtless be welcomed 
by the more enlightened members of Convocation. Fortunately, no violent innovations are called for, no new endowments, or grants of money. The commissioners would have to recommend the renovation of what has fallen into disuse-the improvement of the old rather than the introduction of new and experimental systems ; they would have to give force to existing academical statutes̀, now inoperative, rather than to enact new laws. They might undertake university reform in the temper recommended by Dr. Whewell (p. 138.), "bringing to the task a spirit, not of hatred, but of reverence for the past, not of contempt, but of gratitude towards our predecessors." No new fountains of knowledge are to be sought for in the depths of the earth; they are already at the surface, ready, on the removal of impediments, to overflow and fertilize the soil. When Lord Hastings conquered Delhi in 1817, he found an extensive wilderness near that city, sterile, and parched up by the sun's heat, which had once been cultivated and populous ; for in ancient times it had been irrigated by canals which brought the waters of the Jumna from a distance of 250 miles. The empire which had left these monuments of its ancient grandeur had long passed away, and having fallen to pieces, had formed a multitude of smaller kingdoms, each governed by feebler rulers. In a few years, by the aid of several thousand labourers, directed by skilful engineers, these ancient watercourses were repaired. They had been dry for two centuries and a half ; and on the day appointed for the copious streams to flow once more through the streets of the ancient metropolis, the Hindoo priests went forth in solemn procession, while troops of virgins threw garlands of 
flowers into the waters as they advanced. It was a day of national jubilee and thanksgiving, for the hand of a foreign power had restored to them the works of their forefathers.

But our ancient seats of learning, it will be said, so far from being depopulated, are full to overflowing. Oxford annually refuses to admit new students, because more cannot be accommodated within the college walls. Doubtless, the colleges are full, but can this be said of the university? Have Oxford and Cambridge kept pace, since the commencement of the present century, with the growth of the population, wealth, and desire of education, in the British empire? So many millions have been added to our population, that the clergy have, of necessity, increased in number, and the English bishops have more generally required academical degrees before ordination. This alone has caused a considerable augmentation of students. But is it not notorious that the expensive style of living, and the exclusion of branches of instruction connected with the future professions and individual tastes of students, have kept down the number of academicians? The sons of the aristocracy, and future divines, who, if poor, may eke out their academical income with scholarships and other endowments, constitute the mass of the undergraduates. The colleges have no desire to multiply the number of their pupils; they have already as many as they can teach. The academical fees, and the cost of board and lodging, are very reasonable; but the style of living is so high, that students with small incomes feel themselves in a false position: and this objection has operated far more than religious tests to check the natural increase of the universities. 
Why, it may be asked, should we crowd all the British youth into two ancient seats of learning? Why not promote the growth of other institutions in London, Durham, Scotland, Wales, and Ireland? That such competition should be encouraged, I fully admit ; but it will still be desirable that Oxford and Cambridge should expand freely, and that they should cease to serve as models of an exclusive and sectarian principle. Before the Reformation their spirit was catholic and national: since that period, they have dwindled, not into theological seminaries, for they have never in practice afforded a complete professional course for divinity students, but into places for educating the clergy of the Established Church, and the aristocratic portion of the laity professing the same form of Christianity. Such a system, coupled with the abandonment of professional studies in general, tends to dissever throughout the country men of different callings, creeds, and professions. It has a dissociating influence. It separates during the period of youth the nobility and gentry from the higher portion of the middle classes, the barrister from the attorney, the physician from the surgeon, the legislators and lawyers of England from those civilians to whom the government of eighty millions in India is to be consigned, the members of the Anglican church from the Romanists of Stonyhurst or the Dissenters of Hackney, the civil engineers of Putney from the medical students of London. It disunites these and other sections of the same community, and throws them into antagonist masses, each keeping aloof from the other in cold and jealous seclusion, each cherishing sectarian or party animosities, or professional and social prejudices. Complaints are often heard, and not without reason, of 
the harsh outlines that often separate the different grades of society in this country. It is in the season of youth, and when men are engaged in the common pursuit of knowledge,- - especially if allowed as far as possible to follow the bent of their own tastes and genius, - that friendships might easily be formed tending to soften these hard outlines. At college, they would be brought together on neutral, and usually on friendly ground, where kindly feelings and sympathies would spring up spontaneously, and would be cherished in after-life by congenial souls, however distant the station, or distinct the religious opinions or professional employments of the former fellow-students.*

* While these sheets were passing through the press, an important discussion took place in the House of Commons, in consequence of a motion made April 10th, 1845, by Mr. Christie, M. P. for Weymouth, for a royal commission of enquiry into the state of education in the English universities. I have added and altered nothing since reading this debate, and it will be seen that while there is a coincidence in some of my views with those so ably advocated by many of the parliamentary speakers, there are other grounds taken up by me to which they have not alluded. 


$$
\text { - }
$$

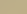




\section{TRAVELS}

IN

N 0 R T H A M E R I C A,

IN THE YEARS 1841-2;

WITH

GEOLOGICAL OBSERVATIONS

ON

T HE U N T E D S T A T E S,

CANADA, AND NOVA SCOTIA.

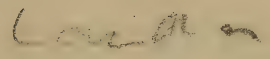

BY CHARLES LYELL, ESQ., F.R.S.

AUTHOR OF THE PRINCIPLES OF GEOLOGY.

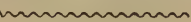

IN TWO VOLUMES.

VOL. II.

NEW-YORK :

WILEY AND PUTNAM, 161 BROADWAY.

1845 . 



\section{CONTENTS OF VOLUME II.}

\section{CHAPTER XIV.}

PAGE.

Dr. Channing.-Agitation in Rhode Island.-Armed Convention.-Sail through Amboy Straits.-Journey to Philadelphia and Baltimore.-Harper's Ferry.-Passage over the Alleghanies by National Road.-Parallel Ridges.-Absence of Drift.-Structure and Origin of Appalachians.-Theory of Subsidence and Contraction of Subterranean Fluid.-Kentucky Farmers.-Emigrants.-Cumberland Coal Field.-Clay with Stigmaria.-Marine Shells in Coal-Measures near Frostburg.-Wide Geographical Distribution of Fossil Coal Plants.......................................

CHAPTER XV.

Alleghany Mountains.-Union.-Horizontal Coal Formation.Brownsville on the Monongahela.-Facilities of Working Coal.-Navigable Rivers-Great Future Resources of the Country.-Pittsburg.-Illinois Coal Field.-Fossil Indian Corn.-Indian Mounds near Wheeling.-General Harrison on their high Antiquity.-Dr. Morton on the aboriginal Indians.-Remarks on the Civilisation of the Mexicans and other Tribes.-Mrarietta.-Silicified Trees or Psarolites of Ohio.-Coal of Pomeroy.-New Settlements.-Cincinnati..

\section{CHAPTER XVI.}

Suression of Strata on the Ohio between Pomeroy and Cininnati.-Return up the Ohio to Rockville.-Waverley Sandstone.-Cliff Limestone.-Denudation.-Blue Limestone of Cincinnati.-Lower Silurian Fossils.-Limited Proportion of Silurian Species common to Europe and America.-Great Devolopment of Brachiopoda.-Deep Sea Formations.-Rarity of Silurian Land Plants.-Silurian Fossil Fish......... 
CHAPTER XVII.

Alluvial Terraces at Cincinnati, and their Origin.-Bones of the Elephant and Mastodon.-Excursion to the Swamps of Big Bone Lick, in Kentucky.-Noble Forest.-Salt Springs. -Buffalo Trails.-Numerous Bones of Extinct Animals.Associated Freshwater and Landshells.-Relative Age of Northern Drift, and Deposits with Bones of Mastodon on the Ohio

\section{CHAPTER XVIII.}

Cincinnati.-Journey across Ohio to Cleveland.-New Clearings - Rapid progress of the State since the year 1800.-Increase of Population in the United States.-Political Discussions.-German and Irish Settlers.-Stump Oratory.Presidential Elections.-Relative Value of Labour and Land......................................

CHAPTER XIX.

Cleveland-Ridges of Land and Gravel along the Southern coast of Lake Erie.-Their Origin.-Fredonia ; streets lighted with natural Gas_-Falls of Niagara.-Burning Spring.Passing behind the Falls._Daguerreotype of the Falls.Boulder Formation of Whirlpool, and Valley of St. David's. -Glacial polishing and Furrows.-Influence of Icebergs on

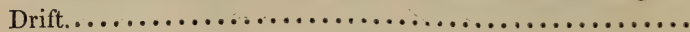

\section{CHAPTER XX.}

Mirage on Lake Ontario.-Toronto.-Excursion with Mr. Roy to examine the Parallel Ridges between Lakes Ontario and Simcoe.-Correspondence of Level in their Base-lines over wide Areas.-Origin of the Ridges.-Lacustrine Theory.Hypothesis of Sand-banks formed under Water.-Rapid Progress of the Colony.-British Settlers unable to spak Eng-

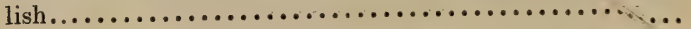

\section{CHAPTER XXI.}

Kingston.-Montreal.-French Population and Language.Quebec. - Soldiers. - Deserters. - Three Rivers. - Scotch Emigrants.-Distinctness of French and British Canadians. -Large Military Force.-American Sympathizers.-Geolological Survey.-Analogy in Structure of Canada and scandinavia.-Section at Falls of Montmorency.-Uncomrortable 
position of lowest Fossiliferous Sandstone to Gneiss.-Supposed Monument of the Commencement of the Organic World.-To what extent the Granitic Rocks are primary.Difficulty of establishing the Date of Metamorphic Action.Two Sources of popular error respecting the more abundant production of Hypogene Rocks at Remote Periods.........

\section{CHAPTER XXII.}

Glacial Furrows in the Valley of the St. Lawrence.-Action of packed ice in the Canadian Rivers.-Boulder Formation with and without Shells.-Gannanoqui.-Mountain of Montreal.Recent Shells in Drift more than 500 feet above the Sea.Lake St. Peter.-Falls of Maskinongé.-Deposit of Shells at Beaufort near Quebec.-Agreement with Swedish Fossils.Shells in Boulder Formation of Lake Champlain.-Burlington, Vermont.-Fossils of Drift imply a colder climate.Scenery of Lake Champlain.-Organic Remains of lowest Silurian Sandstone.-Lingula.-Vermont Mountains.-Inns and Boarding-houses. - Return to Boston.............

\section{CHAPTER XXIII.}

Halifax.-Glacial Furrows in Nova Scotia.-Difference of Climate of Halifax and Windsor.-Tracts covered with $\mathrm{Kal}$ mia.-Linnæa borealis.-High tides of the Bay of Fundy. The Bore.-Recent deposits of Red Mud hardened in the Sun.-Fossil Showers of Rain.-Footprints of Birds, and casts of the same.-Cracks caused by Shrinkage.-Submerged Frost.-Recent Glacial Furrows at Cape Blomidon.-Loaded Ice.-Ice-ruts in Mud....................... 136

\section{CHAPTER XXIV}

Coal Formation of Nova Scotia.-Productive Coal-Measures. Erect Fossil Trees in the Cliffs of the Bay of Fundy.-Section from Minudie to the South Joggins.-Ten buried Forests, one above the other.-Connection of upright Trees with Seams of Coal.-Stigmaria.-Sigillaria.-Evidence of $\mathrm{Re}$ peated Submergence of dry Land.-Theory to explain the Evenness of the Ancient Surface.-Pictou Coal Field.-Bed of Erect Calamites, compared to those of St. Etienne, in France.-List of Species of Nova Scotia Coal-plants.-Fourfifth of these Fossils identified with European Species.Carboniferous Flora of the United States............ 148 


\section{CHAPTER XXV.}

Lower Carboniferous or Gypsiferous Formation of Nova Scotia.-Why formerly considered as newer than the productive Coal.-Determination of its true age.-Sections near Windsor.-Supposed Reptilian Footsteps.-Section on the Shubenacadie.-Large Masses of Gypsum.-Their Origin-Volcanic Action contemporaneous with Nova Scotia Coal Measures.-Limestone with Marine Shells.-Table of Organic Remains of the Carboniferous Limestone of Nova Scotia

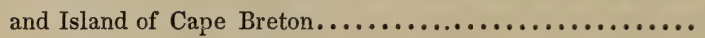

\section{CHAPTER XXVI.}

Progress and Resources of Nova Scotia.-Highland Settlers.Timber Duties.-Cobequid Hills.-Conflagration of Forests. -Albion Mines.-Humming Birds.-Estuary of the Shubenacadie.-Stakes cut by Beavers. - Promotion of Science.Social Equality.-Nova Scotians "going home."-Return to England................................... 


\section{J O UR N A L}

OF A

\section{TOUR IN NORTH AMERICA,}

IN 1841-2.

\section{CHAPTER XIV.}

Dr. Channing.-Agitation in Rhode Island.-Armed Convention.-Sail through Amboy Straits.-Journey to Philadelphia and Baltimore.-Harper's Ferry.-Passage over the Alleghanies by National Road.-Parallel Ridges.-Absence of Drift.-Structure and Origin of Appalachians.-Theory of Subsidence and Contraction of Subterranean Fluid.Kentucky Farmers.-Emigrants._Cumberland Coal Field.Clay with Stigmaria.-Marine Shells in Coal Measures near Frostburg.-Wide Geographical Distribution of Fossil Coal Plants.

April 17, 1842.-During my stay at Boston, I was fortunate enough to hear Dr. Channing preach one of the last sermons he delivered from the pulpit. His declining health had prevented him from doing regular duty of late years; but there seemed no reason to anticipate that he would so soon be taken away from a community over which he exerted a great and salutary influence. His sermon was less impressive than I had expected, and fell short of the high conception I had formed of him from his VOL. II. 
writings; but this I imputed entirely to his want of physical strength, and the weak state of his voice. I had afterwards the pleasure of conversing freely with him at a small dinner party on various subjects in which he was interested; among others, the bearing of geological discoveries, respecting the earth's antiquity and the extinct races of animals, on the Mosaic account of the history of man and the creation. I was struck with the lively interest he took in the political affairs of Rhode Island,-a neighbouring State, containing about 110,000 inhabitants, and now convulsed by a revolutionary movement in favor of an extension of the suffrage. The sympathies of Dr. Channing appeared to lean strongly to the popular party, which, in his opinion, had grievances to complain of, however much, by their violent proceedings, they had put themselves in the wrong.

As some alarmists assured me that the railway to Providence, by which I intended to pass southwards in a few days, "was commanded by the cannon of the insurgents," my curiosity was awakened to inquire into this affair, the details of which were not uninstructive, as giving a curious insight into the character of the New England people, and showing their respect for law and order, even when their passions are highly excited. I found that Rhode Island was still, in the year 1842, governed according to a charter granted by Charles II. in the year 1663, no alteration having been made in the qualifications of voters at the period when the sovereignty was transferred from the crown of Great Britain to the freeholders of Rhode Island. Although the State 
has been flourishing, and is entirely free from debt, a large majority of the people have, for the last forty years, called loudly on the privileged landholders to give up their exclusive right of voting, and to extend the suffrage to all the adult males, in accordance with the system established in all the neighbouring States. The dispute turned mainly on a question of a very abstract nature for the comprehension of the muititude, though in reality one of great constitutional importance; namely, whether the change should be made according to the forms prescribed in the charter of 1663 , or might be effected by the people in its capacity of sovereign, without regard to any established forms. The latter method was advocated by the democratic leaders as most flattering to the people, and with such success that they organized a formidable association in opposition to the government. Their demands did not differ very materially from those which the legislature was willing to concede, except that the democrats claimed the suffrage, not only for every American-born citizen, but also for the new-comers, or the settlers of a few years' standing. Both parties agreed to exclude the free blacks. At length, as their wishes were not complied with, the "Suffrage Convention" resolved to intimidate their opponents by a military enrolment and drilling, and were soon joined by several companies of militia.

The governor of Rhode Island was so much alarmed as to call on the President of the United States to afford him aid, which was declined on the ground that no overt act of violence had been committed. The insurgents then elected a separate 
senate and house of representatives, and one Dorr as governor of the State, who proceeded to Washington, and had an interview with the President of the United States and with several members of congress. Meanwhile military preparations were making on both sides. A second appeal was made in vain by the State of Rhode Island for aid from the federal government at Washington. Meetings of sympathizers were held at New York to co-operate with the popular party, who had now obtained some pieces of cannon, and attempted to get possession of the arsenal at Providence. On this occasion, however, the State government called out the militia, who mustered in great force, and, after a bloodless affray, the popular party, which had already dwindled down to a few hundreds, deserted their leader, Dorr. This champion made his escape, but was soon after taken, tried for high treason, and condemned to imprisonment. Before the conclusion of this affair the government at Washington signified their readiness to furnish the required troops, but their offer of aid came late, and the assistance was no longer needed.

The firmness of the Rhode Island legislature under the threats of the armed populace at home, and, what was more formidable, of the sympathizers from with out, and the respect shown to constitutional forms by the mass of the people in the midst of this excitement, are circumstances highly creditable to the majority of the citizens. It remains to be seen whether an extension of the suffrage, which was afterwards granted, will promote or impede the cause of freedom and good government in this small State. May 2, 1842.-We now set out on a tour to the 
valley of the Ohio and the country west of the Alleghany mountains, taking the railway to Providence, and a steam-boat from thence to New York. Afterwards we went to Philadelphia by Amboy, passing through the beautiful strait which separates the mainland of New Jersey from Staten Island. This winding channel is, in parts, only half a mile, and even less, in width, with many elegant villas and country houses on Staten Island. Its banks are often well-wooded, and it resembles a river, or Homer's description of the broad Hellespont, which, as Gibbon observes, the poet had evidently likened to a river, and not to an arm of the sea.

The trees in New England are now only beginning (in the first week of May) to unfold their leaves, after an unusually mild winter. They remain leafless for nearly seven months in the year, although in latitude $42^{\circ}$ and $43^{\circ} \mathrm{N}$., corresponding geographically to Southern Italy. In New Jersey the scarlet maple is putting forth its young leaves; the horsechestnuts and lime-trees are in bloom; the lilacs flowering in the gardens, and the Judas tree conspicuous with its purplish pink blossom. The dogwood also abounds in the forests, with such a display of white flowers as to take the place of our hawthorn.

We reached Philadelphia without fatigue in less than twenty-two hours, a distance of $\mathbf{3 0 0}$ miles from Boston, having slept on board the steam-boat between Stonington (Connecticut) and New York. We proceeded from Philadelphia to Baltimore, and from thence ascended the beautiful valley of the Patapsco, for 60 miles, to Frederick. Between Baltimore and Frederick, I passed over highly in- 
clined strata of gneiss, mica schist, and other metamorphic rocks, which began to be covered at Frederick, and between that and the first ridge of the Alleghany hills, with unconformable beds of the New Red Sandstone, dipping gently to the southwest, or towards the mountains. We continued chiefly on this red sandstone between Frederick and Harper's Ferry, and then entered again upon mica schist and chlorite slate.

At Harper's Ferry, in Virginia, the Potomac, about fifty miles above Washington, is joined by the Shenandoah, a river as large as itself, and after uniting, they issue through a transverse gorge in the mountains. This gorge interested me from its exact resemblance to the Lehigh Gap, before described, in Pennsylvania, by which the Delaware flows out from the hilly country. The scenery of Harper's Ferry has been overpraised, but is very picturesque.

I had hired a carriage at Frederick to carry me to Harper's Ferry, and thence to Hagerstown, on the main road across the mountains. When I paid the driver, he told me that one of my dollar notes was bad, "a mere personal note." I asked him to explain, when he told me that he had issued such notes himself. " A friend of mine at Baltimore," he said, "who kept an oyster store, once proposed to me to sign twenty-five such notes, promising that if I would eat out their value in oysters, he would circulate them. They all passed, and we never heard of them again." I asked how he reconciled this transaction to his conscience? He replied, that their currency was in a very unsound state, all the banks having suspended cash payment, and their only hope was that matters 
would soon become so bad that they must begin to mend. In short, it appeared that he and his friend had done their best to hasten on so desirable a crisis.

The next day two Marylanders, one of them the driver of the stage coach, declared that if the State should impose a property tax, they would resist payment. As funds are now wanted to pay the dividends on the public debt, the open avowal of such opinions in a country where all have votes, sounded in my ears as of ominous import.

In our passage over the Alleghanies, we now followed what is called the National Road to Cumberland and Frostburg, crossing a great succession of parallel ridges, long and unbroken, with narrow intervening valleys, the whole clothed with wood, chiefly oak. The dogwood, with its white flowers, was very conspicuous. The north-western slopes of the hills were covered with the azalea in full flower, of every shade, from a pale pink to a deep crimson. They are called here the wild honeysuckle. Had not my attention been engrossed with the examination of the geological structure of the numerous parallel chains, the scenery would have been very monotonous, the outline of each long ridge being so even and unbroken, and there being so great a want in this chain of a dominant ridge. There is a remarkable absence of ponds or lakes among these mountains, nor do we see any of those broad, dead flats so common in other chains, especially the Pyrenees, which seem to in dicate the place of ancient lakes filled up with sediment. Another peculiarity, also, of a negative kind, is the entire absence of the boulder formation, or drift with transported blocks, which forms so 
marked a feature in the hills and valleys of New England.

I have before spoken briefly of the structure of the $66-+$ Alleghanies (p. 8 ) and their geological conformation, as explained by the Professors W. B. and H. D. Rogers. The accompanying map (pl. 2) will serve to give the reader some idea of the manner in which the parallel belts, or long narrow zones of disturbed strata of different ages, break out at the surface along the line of this mountain chain, so as to be represented by numerous stripes of colour, running in a general direction from N. E. to S. W. It will be seen that the inferior or older groups of the Silurian series range chiefly along the eastern or south-eastern flank of the Appalachians, while the newer groups of the same series, together with the Devonian or carboniferous formations, make their appearance as we proceed further westward. After having found fossils in such abundance in the corresponding Siluriar, rocks of New York, I was struck with their absence, or much greater rarity, in the inclined strata of these mountains, especially in the oldest limestones, or those corresponding in age to "the Trenton group." I have before endeavoured to give, at p. $\%$, an ideal section of the structure of the Appalachian chain, in accordance with the views of the Professors Rogers, and have described the numerous arches and troughs, or parallel, anticlinal, and synclinal bends into which the strata are folded. Between these and the external geographical features of the country there is a manifest connection; nevertheless, it is necessary to bear in mind that the present outline of the hills has been due to changes long subsequent to the era 
when the rocks acquired their principal flexures and fractures. These changes have consisted of the denuding operations of the sea, which probably took place, in great part at least, during those movements of elevation which, after the period of the New Red Sandstone, uplifted the Appalachian strata to their present level above the ocean.

To those who are not accustomed to reflect on the long succession of natural events, often differing from each other greatly in kind, which have concurred to produce a single geological phenomenon, such as a mountain chain, it will always appear very paradoxical that the structure of such a chain is attributed in great part to the sinking, rather than to the forcing upwards, of a portion of the earth's crust. I shall add, therefore, a few words to the brief remarks before advanced (p. 98), in favour of the theory which attributes the folding of strata such as those of the Alleghanies to subsidence. This hypothesis is simply a modification of one very popular with the earlier geologists, who ascribed the fractured condition of the most ancient rocks to the shrinking of the supposed original fluid nucleus of the planet, it being assumed that the earth passed gradually from a state of fusion by heat to a solid condition. It was truly remarked, that during the process of congelation and contraction, the incumbent strata, or those first solidified, would sink and accommodate themselves to a narrower area, namely, the circumference of a spheroid of smaller diameter, and, according to their different degrees of pliability or hardness, the beds would be bent or broken.

When this theory was first propounded, all the 
disturbances of the rocks were referred to a remote geological era, and supposed to have been nearly simultaneous. We have now ascertained that, on the contrary, they have been produced at a great variety of successive epochs, and that some mountain chains are very modern in the earth's history in comparison with others. Nevertheless, the hypothesis may in a limited sense be quite sound, for we may imagine one part after another of the subjacent nucleus, underlying the thin coating or crust which we explore geologically, to be melted by volcanic heat, and, after expansion, to cool and become again consolidated and collapse. The rocks would undergo some disturbance when they were first uplifted, but when the heat was withdrawn, and contraction took place, there would be a still greater amount of dislocation, crumpling, and folding of the beds. All the elaborate mechanical explanations resorted to in illustration of the doctrine of a general contraction, and a diminution in the size of the entire planet, may be applicable to the phenomena of strata, whether in plains or mountains, which have at successive periods become contorted within limited areas. We have only to substitute the partial liquefaction of the interior of the earth at moderate depths for the primitive fusion of the entire incandescent nucleus, and to suppose that each local development of subterranean heat was followed by refrigeration, and we then discover a cause fully adequate to produce the fracture, plication, and lateral pressure of rocks, at as many successive periods of the past, as the facts now established in geology require.

Nearly all mountain chains can now be shown to 
have been, like the Appalachians, of later date than the creation of organic beings. We also know that, at each geological period characterized by the appearance of distinct races of living beings, the earth's surface, although for the most part tranquil, has been in some regions the theatre of volcanic eruptions. It is very probable that the Silurian, Devonian, and carboniferous strata, which enter into the composition of the Appalachians, underwent the principal movements of upheaval and subsidence to which their prevailing structure is due, at a time when they were still submerged beneath that ocean in which they were originally formed,-for that they were at first marine deposits is testified by their imbedded corals and shells. It is therefore certain that they have undergone some elevation before they arrived at their present position. But we cannot infer from this fact that movements of elevation rather than of subsidence have been most effective in impressing upon them their present structure. The reader will observe, in the section at p. 92, vol. i., that nearly horizontal beds of Newer Red Sandstone (No. 4, fig. 5) rest unconformably on the inclined strata of the Alleghanies. Hence he will perceive that the last series of movements which upraised this continent, was quite distinct from those prior movements, which threw the ancient strata (Nos. 5, 6, 7, fig. 5) into their inclined and curved position.

Having one day entered a stage coach in our passage over these mountains, I conversed with two Kentucky farmers returning in high spirits from Baltimore, where they had sold all their mules and cattle for good prices. They were carrying back their 
money in heavy bags of specie, paper dollars being no longer worthy of trust. They said their crops of grain had been so heavy for several seasons, that it would have cost too much to drag it over the hills to a market 400 miles distant, so they had "given it legs by turning it into mules." I asked why not horses. They said mules were nearly as serviceable, and longer lived, coming in for a share of the longevity of the ass. During several days of travelling in public conveyances on this line of route, we met with persons in all ranks of life, but with no instance of rude or coarse manners.

Entering a cottage at Frostburg, we talked with the mother of the family, surrounded by her children and grandchildren. She appeared prosperous, had left Ireland forty years before, at the age of seventeen, yet could not speak of the old country without emotion, saying, "she should die happy could she but once more see the Cove of Cork." Her children will be more fortunate, as their early associations are all American.

We passed many waggons of emigrants from Pennsylvania, of German origin, each encumbered with a huge heavy mahogany press, or "schrank," which had once, perhaps, come from Westphalia. These antique pieces of furniture might well contain the penates of these poor people, or be themselves their household gods, as they seem to be as religiously preserved. Our companions, the two farmers from Kentucky hefore mentioned, shook their heads, remarking, " that most of them would go back again to Pennsylvania, after spending all their money in the West ; for the old people will pine for their former 
homes, and persuade the younger ones to return with them."

I found some of the iron mines near Frostburg in a bankrupt state, and met a long train of luggage waggons conveying the families of the work-people to new settlements in the West. The disappointed speculators are clamouring for a tariff to protect their trade against English competition. When I urged the usual arguments in favour of free trade, I was amused to perceive how the class interests of my new companions had overcome the usual love of equality, which displays itself in the citizens of the United States. One of the superintendents of the mines expressed surprise that I should have gone through so many States, and not grown tired of the dull mediocrity of income which mere land under the custom of equal division among children produced! "Why limit our civilisation and refinement to small farmers, who expend their surplus gains in tobacco and lawsuits, and can never make ample fortunes, such as spring from manufacturing and commercial industry?"

The iron and coal mines near Frostburg are well worthy of examination. The principal coal seam is ten feet thick, besides six feet of incumbent and less pure carbonaceous matter, the coal bituminous, though containing less volatile matter (oxygen, hydrogen, and nitrogen), than farther west on the Ohio. According to the analysis of my friend Dr. Percy, the quantity of gaseous matter, as compared to the carbon and ash, is only in the proportion of $9 \frac{1}{2}$ per cent. in the specimens of coal which I obtained here from the best seam, whereas the proportion was exactly twice

VOL. II. 
as great in the coal afterwards examined by me farther west at Pomeroy on the Ohio, confirming the theory first advanced by Mr. H. D. Rogers, of the progrossive debituminization of coal as we advance from west to east, or from the horizontal coal fields in the plains of the Ohio to the anthracite of Pennsylvania. (See above, pp. 89 and 249, vol. i.)

The coal measures of this part of Maryland are usually called the Cumberland coal field, from Fort Cumberland, famous for the wars of the English with the French and Indians, in which General Washington took part, before the American Revolution. The carboniferous strata consisting, as usual, of shale, grit, sandstone, limestone, argillaceous iron ore, and coal, are arranged geologically in a trough, about twentyfive miles long, from north to south, and from three to four miles broad. Professor Silliman and his son, who surveyed them, have aptly compared the shape of the successive beds to a great number of canoes placed one within another. The entire thickness of the coal measures is about 1500 feet, including the fundamental quartzose sandstone, called by the miners here, as in England, the millstone grit, which is about forty feet thick, and contains small pebbles, sometimes as big as nuts. These pebbles, therefore, are very diminutive in comparison with those before mentioned as occurring in the same rock in the anthracite basins of north-eastern Pennsylvania, where some of them were stated to be as large as a hen's egg. The conglomerate of that region, it will be remembered, was 1500 feet in thickness, instead of forty feet as at Frostburg, showing the reduction of size in 
the formations of mechanical origin as we proceed westward. (See above, pp. 84 and 86 , vol. i.)

The seams of coal at Frostburg are numerous, there being three workable, besides nine or ten smaller beds. Under several of these, I found clays with Stigmaria, usually, as elsewhere, unaccompanied by any other fossil plants. At one spot, however, on the north-eastern confines of the coal basin, about fifty feet above the millstone grit, I saw a bed of coal, four feet thick, resting on a blue clay containing Stigmaria. This clay was twenty feet thick, and as usual without slaty texture, and the rootlets, commonly called leaves, radiated in all directions from the stems of the Stigmaria. Dispersed plentifully through the same clay, I found the leaves of two species of Pecopteris, and an Asterophyllite, the only instance, in several hundreds which I examined in the United States, where ferns and other coal plants were associated with the Stigmaria, imbedded in its natural position, and not having been drifted.

Higher in the series, but still $\mathbf{3 0 0}$ feet below the principal coal seam, an interesting example occurs of a black shale full of marine shells, resting on a seam of coal about three feet thick. When we have once embraced the doctrine of the origin of pure coal from terrestrial plants, which grew like peat in the spots where we now find them, the contact of an incumbent regular bed of black bituminous slate, ten or twelve feet thick, abounding in sea shells perfectly preserved, is highly interesting. Captain George Green, superintendent of the mines here, kindly presented me with a collection of these shells, which are referable to no less than seventeen species. Some are identical with, 
and almost all the rest have a near affinity to, species found in the Glasgow and other British coal measures. Among the rest is Bellerophon Urii, and two others of the same genus; Euomphalus carbonarius, several species of Nucula, one of Loxonema, and a Producta, allied to $\boldsymbol{P}$. scabricula.

Among the plants occurring usually in the shaly roof or ceiling of the coal, are many identical with European species, such as Calamites dubius and $C$. nodosus, Pecopteris arborescens, and two other species in ironstone shale, both in fructification; also Lepidodendron tetragonum, L. aculeatum, Neuropteris cordata, N. gigantea, Sigillaria reniformis, Caulopteris, Stigmaria, Asterophyllites tuberculata, A. folio$s a$, and many others.

I have alluded to two species of ferns (Pecopteris) in fructification. One of these, abundant in the Jack Porter mine, appears to agree with the European Hemitelites Trevirani of Göppert. It agrees in its venation and the position of its sori with the recent subgenus Goniopteris. When we consider how rapidly the fructification decays on the back of the leaves of ferns, it is wonderful to see them thus petrified. The resemblance, moreover, of some of the common American and European coal plants, such as Pecopteris lonchitica, and $\boldsymbol{P}$. Serlii, to ferns now living, such as Pteris caudata, and $\boldsymbol{P}$. aquilina, is well worthy of notice. The leaves would be undistinguishable if the veins in the fossil species were not finer, closer together, and more perpendicular to the mid-rib, than in the recent ferns.

The specific agreement of so many of the American coal plants with European fossils implies a 
greater uniformity in the carboniferous flora, throughout a large part of the globe, than appears to have prevailed in the co-existing conchological fauna, so far as it is known at present. Those English naturalists who assisted me in naming my American plants, came to the opinion that two thirds of them are the same as species well known in the coal measures on the other side of the Atlantic. M. Adolphe Brongniart informs me that he has arrived at the same result, the general accuracy of which cannot, I think, be impugned by questioning the botanical determinations arrived at from such characters, as the venations of fern leaves, or the markings left by the attachment of fronds on the bark of such trees as Sigillaria and Lepidodendron. If the prevailing vegetation of two distant parts of the globe were now to become fossil, the more common species would nowhere present so uniform a character, if we confined our comparison simply to corresponding organs, namely, the leaves, bark, fruits, the internal woody fibre, whether cellular or vascular, and the roots, if, indeed, the Stigmariæ be of that nature. As to the ferns, it should not be forgotten, that, although in the existing state of the globe, they are less cosmopolite than lichens and mosses, there are some of them, nevertheless, which have an extremely wide range, such as Didymochlana sinuosa, common to Brazil, Java, and Manilla; and Polypodium incanum, to Brazil and the Cape of Good Hope. The recent ferns of North America, according to Pursh's Flora, are sixtynine in number, of which fifteen, according to the same authority, are natives of Europe. It is also worth remarking, that very few of the genera of liv- 
ing ferns are confined to one particular country, or even to one continent. The larger genera appear to have species in nearly all the regions of the world, except the colder latitudes. The mere generic resemblance, therefore, of the fossil ferns of North America and Europe, would not have been remarkable, as indicating a different geographical distribution from that now prevailing.

While at Frostburg, I rode one day on horseback, with Captain Green, superintendent of some of the mines there, and followed the course of Jenning's Run, returning by Cumberland. In this route, we saw a fine section of the coal measures, the underlying grit or conglomerate, and a great thickness (5000 or 6000 feet) of still older Devonian and upper Silurian strata. In those ridges, along the crest of which the yellow and white quartzose carboniferous grit crops out, the monotonous outline was occasionally broken by outliers of the rock twenty feet and upwards in height, remaining in situ with their perpendicular sides and sharp angles (see fig. 7), and show-

Fig. 7 .

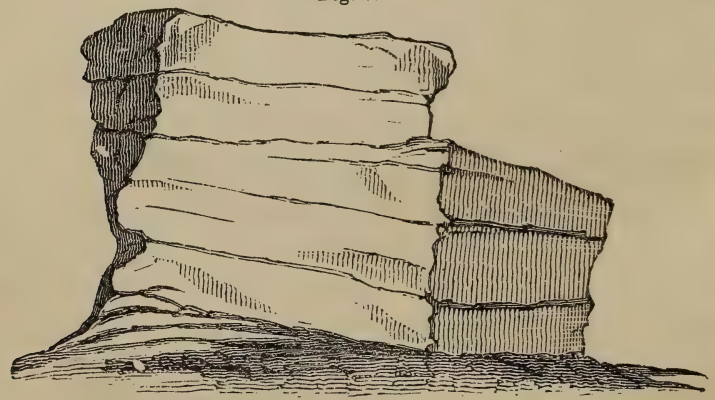

Outlier of quartzase grit 20 feet high. 
ing clearly that large portions of the strata had been removed from the tops of the hills as well as from the valleys.

I was surprised, in the course of our ride along the bottom of a wooded valley, to find the air infected far and wide with a fetid odour, which, my companion informed me, proceeded from a skunk. The animal, he supposed, might be half a mile or more to windward of our path. 


\section{CHAPTER XV.}

Alleghany Mountains.-Union.-Horizontal Coal Formation.Brownsville on the Monongahela.-Facilities of working Coal. -Navigable Rivers.-Great future Resources of the Country.Pittsburg.-Illinois Coal Field.-Fossil Indian Corn.-Indian Mounds near Wheeling.-General Harrison on their high Antiquity.-Dr. Morton on the aboriginal Indians.-Remarks on the Civilisation of the Mexicans and other Tribes.-Marietta.-Silicified Trees or Psarolites of Ohio.-Coal of Pome. roy.-New Settlements.-Cincinnati.

After leaving the small mining village of Frostburg, which is about $\mathbf{1 5 0 0}$ feet above the level of the sea, we continued to ascend and descend a succession of steep ridges till we came to the summit level, where the climate was sensibly colder, and the oaks and other trees still leafless. At Smithfield we crossed a river flowing westward, or towards the Monongahela and Gulf of Mexico, and soon afterwards passed the grave of General Braddock, and followed the line of his disastrous march towards Fort Duquesne, now Pittsburg.

At length we reached Laurel Hill, so called from its rhododendrons, the last of the great parallel ridges of the Alleghanies. From this height we looked down upon a splendid prospect, the low undulating country to the west, appearing spread out far and wide before us, and glowing with the rays of the setting sun. At our feet lay the small town of Union, its site being marked by a thin cloud of smoke, which pleased us by recalling to our minds a familiar feature in the English landscape, not seen in our tous 
through the regions where they burn anthracite, to the east of the Alleghanies.

After enjoying the view for some time we began to descend rapidly, and at every step saw the forest, so leafless and wintry a few hours before, recover its foliage, till the trees and the climate spoke again of spring. I had passed several times over the Pyrenees and the Alps, and witnessed the changes of vegetation between the opposite flanks, or between the summits and base of those mountains; but this was the first time I had crossed a great natural barrier, and found on the other side people speaking the same language, and having precisely the same laws and political institutions.

The parallel ridges before alluded to, between Frostburg and Union, were formed partly of red sandstones (Old Red), but chiefly of white grit, the lowest member of the carboniferous group, each flexure or arch opening out and flattening as we went westward, in the manner explained in my description of the section at page $\mathbf{9 2 ,}$ Vol. I., the strata at the same time becoming more and more horizontal.

At the town of Union, which may be said to lie at the western foot of the mountains, I had an opportunity of seeing coal exposed to view in an open quarry of building stone. The coal seam was three and a half feet thick, with an intervening layer, as usual, between it ard the freestone of dark slate or shale, four feet thick. When traced farther, the shale thinned out gradually, and in a neighbouring quarry, about thirty yards distant, it gave place to the yellow micaceous sandstone, which then formed the roof of 
the coal. These sandstone roofs are comparatively rare in America, as in Europe.

From Union, we went to Brownsville on the Monongahela, a large tributary of the Ohio, where the country consists of coal measures, like those at Union, both evidently belonging to the same series as those more bent and curved beds at Frostburg before described. I was truly astonished, now that I had entered the hydrographical basin of the Ohio, at beholding the richness of the seams of coal, which appear everywhere on the flanks of the hills and at the bottom of the valleys, and which are accessible in a degree I never witnessed elsewhere. The time has not yet arrived, the soil being still densely covered with the primeval forest, and manufacturing industry in its infancy, when the full value of this inexhaustible supply of cheap fuel can be appreciated; but the resources which it will one day afford to a region capable, by its agricultural produce alone, of supporting a large population, are truly magnificent. In order to estimate the natural advantages of such a region, we must reflect how three great navigable rivers, such as the Monongahela, Alleghany, and Ohio, intersect it, and lay open on their banks the level seams of coal. I found at Brownsville a bed ten feet thick of good bituminous coal, commonly called the Pittsburg seam, breaking out in the river cliffs near the water's edge. I made a hasty sketch of its appearance from the bridge, looking down the river, in which the reader will see $(a, \mathrm{Pl}$. VI.) the coal, ten feet thick, covered by carbonaceous shale $(b)$, and this again by micaceous sandstone $(c)$. Horizontal galleries may be driven everywhere at very slight 
To face Vol. II. p. 22.

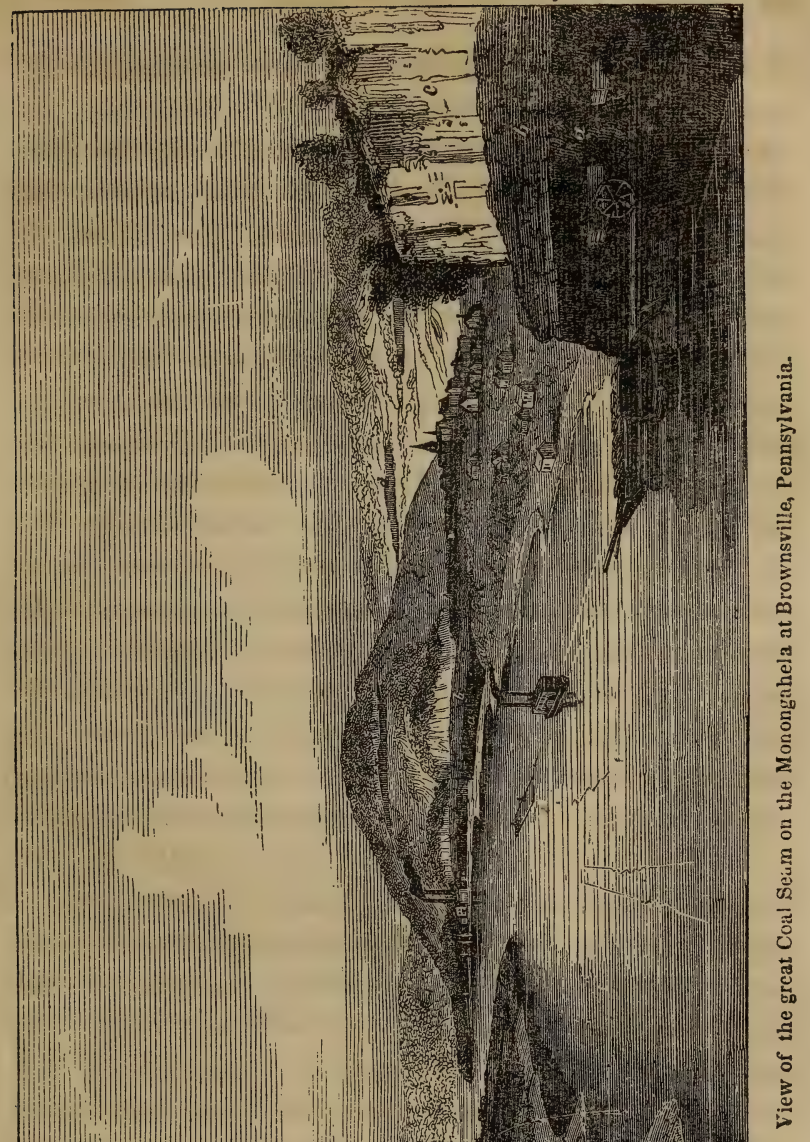




$$
\text { - }
$$


expense, and so worked as to drain themselves, while the cars, laden with coal and attached to each other, glide down, as shown in the plate, on a railway, so as to deliver their burden into barges moored to the river's bank. The same seam is seen at a distance, on the right bank (at $a$ ), and may be followed the whole way to Pittsburg, fifty miles distant. As it is nearly horizontal, while the river descends it crops out at a continually increasing, but never at an inconvenient, height above the Monongahela. Below the great bed of coal at Brownsville is a fire-clay eighteen inches thick, and, below this, several beds of limestone, below which again are other seams. I have also shown in my sketch another layer of workable coal $($ at $d, d)$, which breaks out on the slope of the hills at a greater height. Almost every proprietor can open a coal-pit on his own land, and, the stratification being very regular, they may calculate with precision the depth at which the coal may be won.

So great are the facilities for procuring this excellent fuel, that already it is found profitable to convey it in flat-bottomed boats for the use of steamships at New Orleans, 1,100 miles distant, in spite of the dense forests bordering the intermediate river-plains, where timber may be obtained at the cost of felling it. But no idea can be formed of the importance of these American coal-seams, until we reflect on the prodigious area over which they are continuous. The boundaries of the Pittsburg seam have been determined with considerable accuracy by the Professors Rogers in Pennsylvania, Virginia, and Ohio, and they have found the elliptical area which it occupies to be 
225 miles in its longest diameter, while its maximum breadth is about one hundred miles, its superficial extent being about fourteen thousand square miles.*

In the accompanying map (Pl. II.), the reader will see a sketch of the outline of what has been called the Appalachian coal-field, the vast area of which was before alluded to at p. 88 , Vol. I., as extending for a distance of 720 miles from N. E. to S. W., its greatest width being about 180 miles. This outline must be regarded as giving a mere approximation to its true limits, but when the State Surveys of Pennsylvania and Virginia are published, the extent of this great coal-field will be most accurately delineated. While alluding to the vast area of these carboniferous formations in the United States, so rich in productive coal, I may call attention to the Illinois coal-field, the area of which has been also laid down on the map (Pl. II.), reduced from a large map of the Western States executed by Mr. Dale Owen of Indiana, and of which he has liberally given me the free use for the present publication. That coal field, comprehending parts of Illinois, Indiana, and Kentucky, is not much inferior in dimensions to the whole of England, and consists of horizontal strata; with numerous rich seams of bituminous coal. Its position relatively to the Appalachian coal-field may be seen in the western part of the section at page 92, Vol. I. $†$

At the edge of the left bank of the Monongahela, we collected shells of many species of freshwater

* Trans. of Amer. Geol. 1840, p. 446.

$\dagger$ See also Description of Maps. 
muscles (Unio), and were much interested in finding them all different from those which we had previously met with in the Connecticut, Delaware, and other eastern rivers. We had now in fact entered an entirely new zoological province, so far as conchology was concerned.

May 15, 1842.-We embarked at Brownsville for Pittsburg in a long narrow steamer, which drew only eighteen inches water, and had a single paddle behind like the overshot wheel of a mill. It threw up a shower of spray like a fountain, which had a picturesque effect. The iron works of the machinery and the furnace were all exposed to view, and the engineers were on deck in a place cooled by the free circulation of air.

The wooded hills rise to the height of from 300 to 450 feet above the river between Brownsville and Pittsburg. (See Pl. VI.) The latter place is situated at the junction of the Alleghany and Monongahela rivers, which after their union form the Ohio. It is a most flourishing town, and we counted twentytwo large steamboats anchored off the wharfs. From the summit of the hill, 460 feet high, on the left bank of the Monongahela, we had a fine view of Pittsburg, partially concealed by the smoke of its numerous factories. A great many fine bridges span the two broad rivers above their junction. In the same hill, I saw a fine section of the horizontal coal-measures. Far below the principal seam, and near the level of the river, there is a bed of coal a few inches thick, resting on clay. Upon this coal are layers of shale and limestone, in which I found the same Bellerophon allied to, or identical with, $\boldsymbol{B}$. Urii, and the 
same Leptana sarcinulata, Spirifer, allied to S. Urii, and other shells, which occur at Frostburg, together with Encrinus, and a small coral.

The steamboats on the Ohio cannot be depended upon for punctual departure at the appointed hour like those of the Hudson or Delaware. I therefore took places in a coach for Wheeling, and crossed a low and nearly level country, where I was struck with the absence of drift and boulders, so common in the north. The carboniferous strata were exposed on the banks of every small streamlet, and not concealed by any superficial covering. On reaching one of those innumerable towns to which, as if for the sake of confusion, the name of Washington has been given, I received the agreeable intelligence that, instead of travelling to Wheeling before sunset, I must wait till another mail came up in the middle of the night. I was very indignant at this breach of promise, but was soon appeased by the good-natured landlord and postmaster, who addressed me by the conciliatory appellation of "Major," and assured me that the new post-office regulation was as inconvenient to him as it could possibly be to us.

The next day we embarked at Wheeling on the Ohio for Marietta. I had been requested by my geological friends, when at Philadelphia, to make inquiries respecting some Indian corn said to have been found fossil at some depth in a stratified deposit near Fish Creek, a tributary of the Ohio, and presumed to be of high antiquity. A proprietor who had resided twenty-six years near the spot, assured me that the corn occurred in an island in the river, at the depth of no more than two feet below the 
surface of the alluvial soil. It consisted of parched corn, such as the Indians often buried when alarmed, and in the present year the Ohio had risen so high as to inundate the very spot, and throw down several fresh layers of mud upon the site of the corn.

Five miles below Wheeling, on the left bank of the Ohio, is a terrace of stratified sand and gravel, having its surface about seventy-five feet above the Ohio. On this terrace is seen a large Indian mound. On our arriving at Marietta, I learnt from Dr. Hildreth that skeletons had been found in it at various depths, together with pipe-heads and other ornaments. Their workmanship implies a more advanced state of the arts than that attained by the rude Indians who inhabited this fertile valley when it was first discovered by the white man. There are many other similar mounds in the valleys of the Ohio and its tributaries, but no tradition concerning their origin. One of these, near Marietta, in which human bones were dug up, must be more than eight centuries old, for Dr. Hildreth counted eight hundred rings of annual growth in a tree which grew upon it. But, however high may be the historical antiquity of the mounds, they stand on alluvial terraces which are evidently of a very modern geological date. In America, as in Europe, the oldest monuments of human labour are as things of yesterday in comparison with the effects of physical causes which were in operation after the existing continents had acquired the leading features of hill and valley, river and lake, which now belong to them. Dr. Locke of Cincinnati has shown that one of the earth-works, enclosing about one hundred acres on the great 
Miami, although nearly entire, has been overflowed in a few places, and partially obliterated. He infers from this and other facts, that these mounds extending to high-water mark, and liable to be occasionally submerged, were constructed when the streams had already reached their present levels, or, in other words, their channels have not been deepened in the last 1000 or 2000 years.*

The arguments for assigning a very remote period to the Indian antiquities above alluded to, have been stated with great force and clearness by General Harrison, late President of the United States, who was practically versed in woodcraft, and all that relates to the clearing of new lands. In his essay on the aborigines of the Ohio valley, $\dagger$ he states, that some of these earth-works are not mere mounds, but extensive lines of embankment, varying from a few feet to ninety feet in altitude, and enclosing areas of from one to several hundred acres.

"Their sites," he says, "present precisely the same appearance as the circumjacent forest. You find on them all that beautiful variety of trees which give such unrivalled richness to our forests. This is particularly the case on the fifteen acres included within the walls of the work at the mouth of the great Miami, and the relative proportions of the different kinds of timber are about the same."

He then goes on to observe that if you cut down the wood on any piece of wild land, and abandon it to nature, the trees do not grow up as before, but

* Trans. of Amer. Geologists and Naturalists, p. 232.

† Trans. of Hist. and Phil. Soc. of Ohio, vol. i., 1839. 
one or two, or at most three species get possession of the whole ground, such for example as the yellow locust, or the black and white walnut. The process by which the forest recovers its original state is extremely slow. "On a farm of my own," says he, " at the end of fifty years, so little progress had been made, as to show that ten times that period would be necessary to effect its complete assimilation. When those kinds of timber which first establish themselves have for a long time remained undisputed masters of the soil, they at length die by disease, or are thinned by the lightning or tempest. The soil has no longer a preference for them, and by a natural rotation of crops other species succeed, till at length the more homogeneous growth ceases, and the denuded tract is again clothed with a variety of wood." As the sites of the earthworks command extensive views, it is reasonable to infer that no trees were suffered by the Indians to spring up upon them or in the immediate neighbourhood, and as no difference could be detected in the mixture of trees upon and near the mounds, from the state of the surrounding forest, General Harrison concludes that several generations of trees had succeeded each other, before the present trees began to grow, and that the mounds were probably as ancient at least as the Christian æra. The rich valley of the Ohio, when first discovered by Europeans, was thinly peopled by rude tribes of Indian hunters. In what manner, then, could they have conquered and driven out that more civilized race which evidently preceded them? Harrison suggests that a great flood, like those which occurred in 1793 and 1832 after heavy rain, when 
the Ohio was unusually blocked up with ice, may have swept off Indian towns and villages, and caused the terrified occupants to remove. The flood would be construed by their superstition into a warning from heaven to seek a residence upon sume smaller streams; and before the remembrance of this fearful calamity had been effaced from their imaginations, the deserted region would, from its great fertility, become an unusual resort of game. It would then be a common hunting ground for the hostile tribes of the north and south, and consequently a great arena for battle. In this state it continued when first visited by the whites.

Dr. Morton, in his luminous and philosophical essay on the aboriginal race of America, seems to have proved that all the different tribes, except the Esquimaux, are of one race, and that this race is peculiar and distinct from all others.* The physical characteristics of the Fuegins, the Indians of the tropical plains, those of the Rocky Mountains, and of the great valley of the Mississippi, are the same, not only in regard to feature and external lineaments, but also in osteological structure. After comparing nearly 400 crania derived from tribes inhabiting almost every region of both Americas, Dr. Morton has found the same peculiar shape pervading all, "the squared or rounded head, the flattened or vertical occiput, the high cheek bones, the ponderous maxillæ, the large quadrangular orbits, and the low receding forehead." The oldest skulls from the cemeteries of Peru, the tombs of Mexico, or the 
mounds of the Mississippi and Ohio, agree with each other, and are of the same type as the heads of the most savage existing tribes. If we next turn to their arts and inventions, we find that a canoe excavated from a single log was the principal vessel in use throughout the New World at the period of its discovery, the same primitive model existing among the Fuegians, the predatory Caribs, and the more advanced Mexicans and Peruvians.

But although the various tribes remained in general as stationary in all matters requiring intellectual effort, as in their nautical contrivances, we behold with surprise certain points, of which Mexico was the most remarkable, where an indigenous and peculiar civilisation had been developed, and had reached a high degree of perfection. However much we may admire their architecture, their picture-writing, and historical records, it is their astronomical science in particular, as Mr. Prescott observes, which was disproportioned to their advancement in other walks of civilisation.* They had fixed the true length of the tropical year with a precision unknown to the great philosophers of antiquity, which could only be the result of a long series of nice and patient observations. By intercalating a certain number of days into the year at the expiration of every fifty-two years, they had even anticipated the Gregorian reform, so that their calendar at the time of the conquest was more correct than that of the Europeans. To ascribe the civilisation of the Toltecs to an Asiatic origin, while it is admitted that there was no correspondence or 
relationship between their language and that of any known Asiatic nation, appears to me a baseless hypothesis, however true it may be that the aboriginal Americans had in the course of ages derived some hints from foreign sources. They could only have taken advantage of such aid, conjectural as it is, and without proof, if they were already in a highly progressive state; and if such assistance be deemed sufficient to invalidate their title to an independent civilisation, no race of mankind can ever make good their claim to such an honor.

If, then, a large continent can be inhabited by hundreds of tribes, all belonging to the same race, and nearly all remaining for centuries in a state of apparently hopeless barbarism, while two or three of them make a start in their social condition, and in the arts and sciences; if these same nations, when brought into contact with Europeans, relapse and retrograde until they are scarcely distinguishable in intellectual rank from the rude hunter tribes descended from a common stock; what caution ought we not to observe when speculating on the inherent capacities of any other great member of the human family? The negro, for example, may have remained stationary in all hitherto explored parts of the African continent, and may even have become more barbarous when brought within the influence of the white man, and yet may possess within his bosom the germ of a civilisation as active and refined as that of the golden age of Tezcuco.

In proportion as the Ohio falls gradually in level after its inundations, it leaves a great succession of steps cut in its mud banks, each from four to ten 
inches above the other. I was informed that the action of the waves raised by the steamboats causes this undermining of the bank. It appeared to me an exact miniature representation of the form in which the waves of the sea have denuded the land on the sides

Fig. 8.

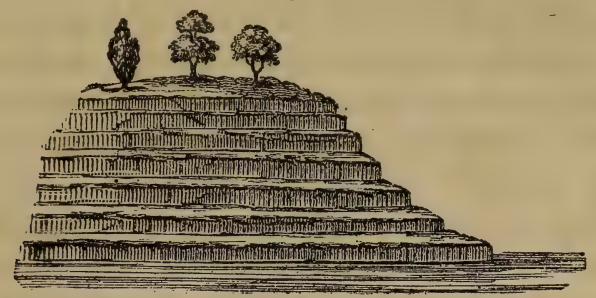

Form of mud-banks of the Ohio River.

of some valleys in the limestone districts of Sicily and other countries bordering the Mediterranean.

When at Marietta, I examined, with Dr. Hildreth, some of the uppermost beds of the coal-measures, consisting of red shale, in which impressions of ferns, especially Pecopteris cyathcea Brongn., or a species closely allied to it, abound. From a locality in this part of Ohio, which I did not visit, but which must belong to the newest division of the carboniferous strata, the trunks of silicified trees have been procured in abundance, with one of which Dr. Hildreth presented me, and which Mr. R. Brown has s.nce ascertained to belong to the genus Psaronius of Cotta. These stems, usually called Psarolites, have also been described by M. Ad. Brongniart as composed of two distinct parts, an outer zone, consisting of a great number of nearly cylindrical bundles of vessels, supposed to have been roots which proceeded from 
the stem near its base, and an inner part or axis. In the exterior portion, the fossil air-roots have a vascular tissue, but there is often a delicate cellular tissue interposed between them. In the axis, on the other hand, or central part of the stem, the vessels form zigzag or wavy bands, resembling those of ferns. These flexuous and vermiform bands are entirely composed of barred or scalariform vessels quite similar to those of ferns and Lycopodia. M. Adolphe Brongniart, therefore, considers the psarolites to have been the bases of the trunks of lycopodiaceous trees; but other eminent botanists incline rather to the opinion that they were true arborescent ferns.

I have examined at Autun, in France, the spot where more than one species of this genus occurs. The geological position of the fossils, as well as the associated plants and ichthyolites, imply that the beds containing them belong to the uppermost coal measures. The same appears to hold true of the strata at Chemnitz in Saxony, from which Cotta procured several species, as also in regard to the only other places in Europe where psarolites have been met with, namely, Neu Paka in Bohemia, and Ilmenau in Saxe Weimar. Some species are common to each of the spots above enumerated; but the American fossil appears to have been distinct from all, and is remarkable for the small size of the outer zone of roots when compared to the central axis. The latter is often no more than two inches in diameter, while the whole trunk is fourteen inches. My friend Mr. Robert Brown possesses a psarolite which he received from the northern part of Brazil.

May 20.-From Marietta we descended the river, 
about a hundred miles, to Pomeroy, where I entered a coal mine which had been worked horizontally in the face of a cliff on the right bank of the Ohio. The coal was bituminous, and I have already mentioned (p. 248, Vol. I.) that Dr. Percy has found the portion of volatile ingredients (hydrogen, oxygen, and nitrogen) to constitute nineteen per cent. of the whole mass, which, except a slight quantity of ash, is all carbon.* In appearance, the coal greatly resembles charcoal, and, although very pure, its structure displays, in a remarkable manner, the vegetable origin of the mass. In the roof or ceiling of the gallery were seen flattened stems of Calamites Suckowii and $C$. dubius, matted together, in the same manner as I have seen these species occurring in the shales of our English coal mines, especially in Northumberland and Durham. The leaves, also, of ferns, Pecopteris arborescens, $P$. plumosa, Neuropteris cordata, Cyclopteris dilatata, besides Asterophyllites foliosa, Flabellaria, and other plants, were spread out on the flat surface of the shale. The Sigillariæ are particularly abundant in the Ohio coal-field, and about half of those which I obtained are decidedly identical with European species.

We were fortunate, when at Pomeroy, to fall in with some New England settlers, who were nearly related to several of our most valued friends at Boston. Their description of what they had gone through since they first founded this flourishing colony in the wilderness, reminded us of that entertaining volume recently published in the United States, called

* See Journ. of Geol. Soc. London, vol. i., p. 207. VOL. II. 
"A New Home: Who'll Follow?" It is not the trees and their rank growth on the uncleared land, nor the wild animals, which are the most uncongenial neighbours to persons of superiour education and refinement in a new settlement. To enjoy facilities, therefore, of communicating rapidly with the civilized Eastern States by founding their new town on the banks of a great navigable river, or close to some main road in the interior, is a privilege truly enviable. I remember wondering, when I first read Homer's graphic sketch of the advantages of wealth, that he should have placed his rich man's mansion on the road side-

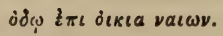

To an Englishman, the poet's notion seemed very un-aristocratic, for we are almost irresistibly reminded of the large sums which an English country gentleman would expend in order to remove the high road to a respectful distance. Probably the present condition of Ohio, rather than that of a county of parks and mansions like Surrey, was the model most frequently present to the minds of the migratory Greeks of the Homeric age.

From Pomeroy, a large steamboat carried us more than 200 miles in about fifteen hours, down the broad, winding stream, past many a well-wooded island, to Cincinnati, where we were struck with the appearance of commercial activity, the numerous wharfs and steamboats, the wide streets and handsome buildings. 


\section{CHAPTER XVI.}

Succession of Strata on the Ohio between Pomeroy and Cincinnati.-Return up the Ohio to Rockville.-Waverley Sandstone.-Cliff Limestone.-Denudation.-Blue Limestone of Cincinnati.-Lower Silurian Fossils. - Limited Proportion of Silurian Species common to Europe and America.-Great Development of Brachiopoda.-Deep Sea Formations.-Rarity of Silurian Land Plants.-Silurian Fossil Fish.

Between the western extremity of the Appalachian coal field and Cincinnati, as will be seen by referring to the section given at p. 92, Vol. I., the different formations, from the Devonian to the Lower Silurian inclusive, come up to the surface in succession, being well exposed in the cliffs or steep slopes of the hills which bound the Ohio valley. I have already mentioned a fine seam of coal at Pomeroy, beneath which, farther to the westward, the lower coalmeasures are seen, and at length at Portsmouth, the inferior conglomerate or millstone grit, next to which, the formation, called by the Ohio geologists the Waverley sandstone, the equivalent of the Devonian formation (No. 9, in the large map, Pl. II.) makes its appearance. To this sandstone, the Upper Silurian slates and limestones (Nos. 10, 11, and 13 of the map) succeed in the descending order, and lastly, at Cincinnati, the Lower Silurian groups (Nos. 14 and 15 of the map) are exhibited in the hills, and in the bed of the Ohio at low water.

Having, when I came down the Ohio, made the 
last part of my journey in the dark, I re-ascended the river for a hundred miles, in company with Dr. Locke, a geologist lately engaged in the State survey of Ohio, and who liberally devoted his time to aid me in my inquiries. I was desirous of seeing the rocks corresponding to the Old Red sandstone before mentioned, and with this view we landed at Rockville, about eighteen miles below Portsmouth, and examined the Waverley sandstone at that place. Retaining in my mind a perfect recollection of the aspect of the deposits intervening in the State of New York, between the Coal and the Upper Silurian groups, at the distances of 400 and 500 miles, I was struck with their extraordinary decrease in volume, the absence of some formations, and the complete identity of those sets of strata which remained. I have before alluded to the gradual thinning out of the coarse sedimentary rocks, both in the Silurian and Carboniferous series of the U. S., as we proceed westward, and the increased thickness of many of the calcareous formations. The Waverley sandstone of Rockville has been recognized by $\mathrm{Mr}$. Hall as the representative of the Chemung and Portage groups of the New York Reports. It contains here many ripple-marked flags with partings of shale. The surfaces of the slabs of sandstone display the festoon-shaped fucoid, called here Fucoides cauda galli, from its resemblance to a cock's tail. I saw some single individuals of this plant extending through layers eight inches thick. There were no associated shells; but in some of the uppermost strata of the series we found spirifers and other brachiopods, with many encrinites. 
Between Rockville and Cincinnati the bituminous shales corresponding to the Hamilton group (or No. 10 of the large map) are seen, and below them what is called the "Cliff limestone," which is considered, and, I believe correctly, by Mr. Hall, as the representative both of the Helderberg and Niagara limestones of New York. Among the characteristic shells, I observed the Pentamerus oblongus, so abundant in the Clinton group of New York, a shell considered by Messrs. Murchison and De Verneuil to mark the line of separation between the Upper and Lower Silurian rocks of Europe.

In discussing with Dr. Locke the probability of the former continuity of the Illinois and Appalachian coal-fields (see the section, Vol. I. page 92), and the possible extension of the strata (Nos. 5, 6, and part of 7 of that section, or $9,10,11$, and 13 of the large map) over that flat dome on the middle part of which Cincinnati is built, we endeavoured to calculate the height which the central area would have attained, if the formations supposed to have been removed by denudation were again restored. In that case the thickness of the strata of coal, subjacent conglomerate, Devonian and Upper Silurian beds, which must have been carried away, could not, if we estimate their development from the mean of their aggregate dimensions on the east and west of Cincinnati, have been less than 2000 feet. The tops of the hills near Cincinnati, composed of the blue limestone, are about 1400 feet above the level of the sea. If, then, the formations presumed to have been destroyed by de. nudation were replaced, the height of the dome 
would be about 3500 feet, or exceeding the average elevation of the Alleghany Mountains.

The thinning out and disappearance of the mudstones and sandstones of the more eastern States, causing limestones, such as the Helderberg and Niagara, so widely separated in New York, to unite and form single and indivisible masses in Ohio, affords no argument against the classification of the New York geologists. Their grouping of the subordinate members of the Devonian and Silurian systems has been based on sound principles; on mixed geographical, lithological, and paleontological considerations; and the analogy of European geology teaches us that minor subdivisions, however useful and important within certain limits, are never applicable to countries extremely remote from each other, or to areas of indefinite extent.

The rock forming the hills and table lands around Cincinnati, called the blue limestone, has been commonly referred to the age of the Trenton limestone of New York (No. 15, map, Pl. II.), but is considered by Messrs. Conrad and Hall, and I believe with good reason, as comprehending also the Hudson River group (No. 14 of map). It seems impossible, however, to separate these divisions in Ohio, so that the district coloured blue (No. 15) may be regarded as agreeing with Nos. 14 and 15 in other parts of my map. Several of the fossils which I collected at Cincinnati, the encrinites and Aviculæ (of the subgenus Pterinea) in particular, agree with those which I afterwards procured near Toronto, on the northern shores of Lake Ontario.

After seeing at Cincinnati several fine collections 
of recent and fossil shells in the cabinets of Messrs. Buchanan, Anthony, and Clark, I examined with care the quarries of blue limestone and marl in the suburbs. The organic remains here are remarkably well preserved for so ancient a rock, especially those occurring in a compact argillaceous blue limestone, not unlike the lias of Europe. Its deposition appears to have gone on very tranquilly, as the Lingula has been met with in its natural and erect position, as if enclosed in mud when alive, or still standing on its peduncle. Crustaceans of the genus Trinucleus are found spread out in great numbers on layers of the solid marl, as also another kind of trilobite, called Paradoxides, equally characteristic of the Lower Silurian system of Europe. The large Isotelus gigas, three or four inches long, a form represented, in the Lower Silurian of Northern Europe, by the Asaphi with eight abdominal articulations, deserves also to be mentioned, and a species of graptolite. I obtained also Spirifer lynx in great abundance, a shell which Messrs. Murchison and De Verneuil regard as very characteristic of the lowest Silurian beds of Russia and Sweden. Among the mollusca, I may also mention Leptana sericea, Orthis striatula, Bellerophon bilobatus, Avecula of the subgenus Pterinea, Cypricardia, Orthoceras, and others. There were also some beautiful forms of Crinoidea, or stone-lilies, and many corals, which Mr. Lonsdale informs me differ considerably from those hitherto known in Britain, a circumstance probably arising from the small development of coralline limestones in the Lower Silurian strata of our island. Several species 
of the new genus Stenopora of Lonsdale are remarkably abundant.

In regard to the proportion of species common to the Silurian beds of Europe and America, whether of the lower or upper division, I may confidently affirm, that it is not greater than a naturalist would have anticipated, from the analogy of the laws governing the distribution of living invertebrate animals. A contrary opinion has prevailed very widely, it being rashly assumed, that at remote epochs the majority of species were far more cosmopolite than in modern times.

The recent researches of Messrs. Murchison and De Verneuil point to the conclusion that the fossil shells, corals, and trilobites of the Silurian system of Scandinavia, and Russia, resemble greatly those of the British Isles; yet nearly half the species which they collected there were different from ours, and the departure from a common type was far more conspicuous in the Lower Silurian fossils of Britain and Russia, than in those of the upper division. When the same fossils of Northern Europe were compared by M. de Verneuil with those brought by me from America, the distinctness was obviously much greater, although the representation of generic forms, whether in the organic remains of the upper or lower Silurian strata, was most clear and satisfactory.

On both sides of the Atlantic, these ancient marine formations are characterized by a prodigious development of one peculiar family of mollusca, called brachiopoda (palliobranchiata)-shells, which, as they inhabit deep water, are little known, and have re- 
ceived no common name in our language. They are represented by the living genera Terebratula, Orthis, Lingula, Orbicula, and Crania. The existence of Orthis, a form till lately supposed to be extinct, has been made known to us by the researches of Philippi in the Mediterranean. Some other genera may hereafter be detected by deep dredging, for we learn from Professor E. Forbes, that at the depth of 100 fathoms in the Mediterranean the profusion of individuals of certain species of Terebratula is extremely great. Nevertheless it may be safely assumed, that the present seas, as well as the tertiary strata of the epochs immediately preceding our own, exhibit a smaller variety in the forms of this tribe of mollusca than the Silurian rocks in which they seem to have attained their maximum of development. The oldest known fossiliferous period was in fact the age of brachiopods ; as the carboniferous period was that of ferns, and the oolitic that of reptiles.

The great number of crustaceans of the extinct family called Trilobites, is also another feature of the formations older than the carboniferous, and especially of the Silurian rocks. No country is richer in fossils of this class than the United States ; and Mr. Conrad has given a table of distinct genera of trilobites, which characterize his Upper, Middle, and Lower Silurian formations of New York, each of which larger divisions he considers to be quite as distinct as the Devonian, and as capable of being classed as an independent group by reference to organic remains.*

* Journ. of Acad. Nat. Sci., Philadelphia, 1842, vol. viii., part 2, p. 233. 
There are some negative characters showing a resemblance between the most ancient of the fossiliferous rocks yet known in Europe and America, which deserve notice, although they belong to a perfectly different order from those before mentioned, as deduced from the analogy of organic forms. Of these points of agreement, the most remarkable are the absence or extreme rarity of land plants and vertebrate animals. That the vegetable world had already been called into existence is proved by the presence of various forms of fucoids, which are plentifully distributed through every part of the series. Some of the slabs of the lowest Silurian slates of Wales are covered with sea-weeds of such genera as are plainly indicative, like the brachiopoda, of deep water. There is, indeed, every reason to conclude that the Silurian deposits generally were formed far from land, which would alone explain the extreme scarcity of terrestrial plants; for how seldom do we meet with wood or fruits floating in mid ocean; and, if they are sometimes carried there by currents, how rarely can we expect them to sink to the bottom precisely in those places where, before decay, they may become enveloped and permanently preserved in sediment.

A few examples, however, of Devonian and Silurian land plants have been brought to light in the course of the New York survey. One of these was shown me by Mr. Vanuxem, and has been figured in his final Report, p. 15\%. It appeared to me more allied to the Lepidodendron than any fossil genus hitherto described. Its position is in the Hamilton or Upper Silurian group, in which we find a great 
variety of trilobites, Spiriferæ, and other brachiopoda and corals, all agreeing perfectly with European Upper Silurian types. Other plants allied to these, and ferns, have been met with in the lowest Devonian or Chemung strata of the State of New York (the olive slate of Pennsylvania and Virginia), associated with fossil shells, very closely allied to the Silurian.* These exceptions to the general rule have been found in those eastern parts of the United States where the Devonian and Silurian sandstones and mudstones are of the greatest thickness, and which we may therefore presume to have originated nearest to the lands then exposed to denudation. The neighbouring continent of that remote epoch may probably have occupied the space now covered by the Atlantic, and there may have been anather in the Pacific, while the lands now existing were then the site of deep oceans.

The greater the lapse of ages which separates the origin of a given set of strata from our own times, the greater is the probability that our acquaintance with those strata will relate chiefly to pelagic deposits, or those formed in deep seas, and far from land. It must require a long continuance of subterranean movements, and a frequent shifting of the principal areas of upheaval, before extensive tracts of the bed of deep oceans, such as the Atlantic and Pacific, can be converted into continents. On the other hand, we may presume that the estuary, littoral, and lacustrine strata of such remote ages, being at first of small horizontal extent, as compared to the con- 
temporaneous coral reefs and fine sedimentary deposits of the ocean, would have become in great part submerged, or covered by newer formations, or destroyed by denudation, during that immense interval of time which separates their origin from our own period.

In regard to the rarity of marine vertebrate animals in the oldest rocks, it may perhaps be no greater than is observed in strata of more modern date, formed in seas of equal depth, or at points as remote from the land. Many years have not elapsed since the Old Red sandstone was thought to be barren of ichthyolites; but now, in addition to the numerous genera found in Scotland by Mr. Hugh Miller, and those described by M. Agassiz, the last-mentioned zoologist has announced that nine genera of sharks of the division Cestracion occur in the Devonian beds of Russia, examined by Messrs. Murchison and De Verneuil. The appearance of fish so highly organized in some of the oldest formations, is strongly opposed to the theory of progressive development advocated by some writers, and imagined by them to derive support from recent geological discoveries.

In England, the remains of fish have long been known in the highest beds of the Upper Silurian, and they have lately been found as far down as the Wenlock limestone. The New York surveyors have met with them in more than one member of the Helder berg series (No. 11, Map. pl. II.) Long ichthyodorulites, or spines of the dorsal fins of fishes, have been obtained, for example, from the Corniferous limestone. But the lowest rock in which they have been traced in America is, I believe, the Clinton group, which 
may be considered the bottom of the Upper, or top of the Lower, Silurian series. Mr. H. D. Rogers informs me, that he and his brother have traced the scales of fish through strata of this series from the south-western part of Virginia to the north branch of the Susquehanna, in Pennsylvania.

Professor E. Forbes, after acquiring much experience, by dredging in the Mediterranean, of the fauna which characterizes the sea at different depths, has inferred that the Silurian seas in those areas hitherto examined were at first very deep' and tranquil, although in parts they afterwards grew shallower. The following are the principal grounds of this conclusion:-first, the small size of the greater number of conchifera; secondly, the paucity of pectinibranchiata (or spiral univalves); thirdly, the great number of floaters, such as Bellerophon, Orthoceras, \&c.; fourthly, the abundance of brachiopoda; fifthly, the absence or great rarity of fossil fish; sixthly, the deep-water forms of most of the sea-weeds; and seventhly, the absence of land plants. 


\section{CHAPTER XVII.}

Alluvial Terraces at Cincinnati, and their Origin.-Bones of the Elephant and Mastodon.-Excursion to the Swamps of Big Bone Lick, in Kentucky.-Noble Forest.-Salt Springs.Buffalo Trails.-Numerous Bones of extinct Animals.-Associated Freshwater and Land Shells.-Relative Age of Northern Drift, and Deposits with Bones of Mastodon on the Ohio

The Ohio river at Cincinnati, and immediately above and below it, is bounded on its right bank by two terraces, on which the city is built; the streets in the upper and lower part of it standing on different levels. These terraces are composed of sand, gravel, and loam, such as the river, if blocked up by some barrier, might now be supposed to sweep down in its current, and deposit in a lake. The upper terrace, $b$ (fig. 9), is bounded by steep hills of ancient fossiliferous rocks. A, the blue, Lower Silurian limestone, mentioned in the last chapter, in horizontal stratification. The higher terrace, $b$, is about 60 feet above the lower, and this again about 60 feet above low water in the Ohio, $d$. The geologists here are convinced that the inferior terrace, $c$, is of newer origin than $b$, as shown in the section (fig. 9), and proved by excavations, not exposed at the time of my visit,

In sinking a well through $c$, at the distance of 300 yards from the Ohio, and at the depth of 50 feet from the surface, they found, at $e$, pieces of wood and many walnuts in a bed of silt.

Near the edge of the higher terrace, in digging a gravel-pit, which-I saw open at the end of Sixth 
Fig. 9.

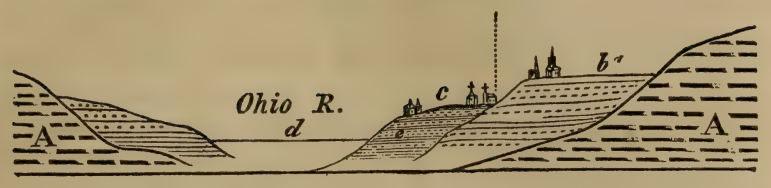

A. Blue limestone (Lower Silurian).

b. Upper terrace. c. Lower terrace.

e. Fossil wood and nuts, \&cc., found here in silt.

street, they discovered lately the teeth of the Elephas primigenius, the same extinct species which is met with in very analogous situations on the banks of the Thames, and the same which was found preserved entire with its flesh in the ice of Siberia. Above the stratum from which the tooth was obtained, I observed about six feet of gravel covered by ten feet of fine yellow loam, and below it were alternations of gravel, loam, and sand, for 20 feet. But I searched in vain for any accompanying fossil shells. These, however, have been found in a similar situation at Mill Creek, near Cincinnati; a place where several teeth of mastodons have been met with. They belong to the genera Melania, Lymnaa, Amnicola, Succinea, Physa, Planorbis, Paludina, Cyclas, Helix, and $P$ upa, all of recent species, and nearly all known to inhabit the immediate neighbourhood. I was also informed that, near Wheeling, a bed of freshwater shells, one foot thick, of the genus Unio, is exposed at the height of. 120 feet above the mean level of the Ohio. The remains of the common American mastodon (M. giganteus) have also been found at several points in the strata in the upper terrace, both above and below Cincinnati. 
Upon the whole it appears, that the strata of loam, clay, and gravel, forming the elevated terraces on both sides of the Ohio and its tributaries, and which we know to have remained unaltered from the era of the Indian mounds and earthworks, originated subsequently to the period of the existing mollusca, but when several quadrupeds now extinct inhabited this continent. The lower parts both of the larger and smaller valleys appear to have been filled up with a fluviatile deposit, through which the streams have subsequently cut broad and deep channels. These phenomena very closely resemble those presented by the loess, or ancient river-silt of the Rhine and its tributaries, and the theory which I formerly suggested to account for the position of the Rhenish loess (also charged with recent land and freshwater shells, and occasionally with the remains of the extinct elephant) may be applicable to the American deposits.

I imagined first a gradual movement of depression, like that now in progress on the west coast of Greenland, to lessen the fall of the waters, or the height of the land relatively to the ocean. In consequence of the land being thus lowered, the bottoms of the main and lateral valleys become filled up with fluviatile sediment, containing terrestrial and freshwater shells, in the same manner as deltas are formed where rivers meet the sea, the salt-water being excluded, in spite of continued subsidence, by the accumulation of alluvial matter, brought down incessantly from the land above. Afterwards, I suppose an upward movement gradually to restore the country to its former level, and, during this upheaval, the rivers remove a large part of the accumulated mud, sand, and gravel. I 
have already shown that on the coast of Georgia and South Carolina (see Vol. I., p. 164), in the United States, we have positive proofs of modern oscillations of level, similar to those here assumed.

Two days after I reached Cincinnati, I set out, in company with two naturalists of that city, Mr. Buchanan and Mr. J. G. Anthony, who kindly offered to be my guides, in an excursion to a place of great geological celebrity in the neighbouring State of Kentucky, called Big Bone Lick, where the bones of mastodons and many other extinct quadrupeds had been dug up in extraordinary abundance. Having crossed the river from Cincinnati, we passed through a forest far more magnificent for the size and variety of its trees than any we had before seen. The tulip-tree (Liliodendron tulipiferum) the buckeye, a kind of horse-chestnut, the shagbark hickory, the beech, the oak, the elm, the chestnut, the locust-tree, the sugar-maple, and the willow, were in perfection but no coniferous trees,-none of the long-leaved pines of the Southern Atlantic border, nor the cypress, cedar, and hemlock of other States. These forests, where there is no undergrowth, are called "wood pastures." Originally the cane covered the ground, but when it was eaten down by the cattle, no new crop could get up, and it was replaced by grass alone.

Big Bone Lick is distant from Cincinnati abouf twenty-three miles in a S.W. direction. The intervening country is composed of the blue argillaceous limestone and marl before mentioned, the beds of which are nearly horizontal, and form flat table-lands intersected by valleys of moderate depth. In one of 
these, watered by the Big Bone Creek, occur the boggy grounds and springs called Licks. The term Lick is applied throughout North America to those marshy swamps where saline springs break out, and which are frequented by deer, buffalo, and other wild animals for the sake of the salt, whether dissolved in the water, or thrown down by evaporation in the summer season, so as to encrust the surface of the marsh. Cattle and wild beasts devour this incrustation greedily, and burrow into the clay impregnated with salt, in order to lick the mud. Bartram, the botanist, tells us, that in his time (1790) he visited Buffalo Lick in Georgia, forming part of a cane swamp, in which the head branches of the Ogeechee river take their rise. The lick consisted of "whitecoloured tenacious fattish clay, which all kinds of cattle lick into great hollows, pursuing the delicious vein." "I could discover nothing saline in its taste, but an insipid sweetness. Horned cattle, horses, and deer are immoderately fond of it, insomuch that their excrement, which almost totally covers the earth to some distance round this place, appears to be perfect clay, which, when dried by the sun and air, is almost as hard as brick." (Travels in N. and S. Carolina, \&c., p. 39.)

The celebrated bog of Kentucky is situated in a nearly level plain, in a valley bounded by gentle slopes, which lead up to the table-lands before mentioned. The general course of the meandering stream which flows through the plain, is from east to west. There are two springs on the southern or left bank, rising from marshes, and two on the opposite bank, the most western of which, called the Gum Lick, is 
at the point where a small tributary joins the principal stream. The quaking bogs on this side are now more than fifteen acres in extent, but all the marshes were formerly larger before the surrounding forest was partially cleared away. The removal of tall trees has allowed the sun's rays to penetrate freely to the soil, and dry up part of the morass.

Within the memory of persons now living, the wild bisons or buffaloes crowded to these springs, but they have retreated for many years, and are now as unknown to the inhabitants as the mastodon itself. Mr. Phinnel, the proprietor of the land, called our attention to two buffalo paths or trails still extant in the woods here, both leading directly to the springs. One of these in particular, which first strikes off in a northerly direction from the Gum Lick, is afterwards traced eastward through the forest for several miles. It was three or four yards wide, only partially overgrown with grass, and, sixty years ago, was as bare, hard, and well trodden as a high road.

The bog in the spots where the salt springs rise is so soft, that a man may force a pole down into it many yards perpendicularly. It may readily be supposed, therefore, that horses, cows, and other quadrupeds, are now occasionally lost here; and that a much greater number of wild animals were mired formerly. It is well known that, during great droughts in the Pampas of South America, the horses, cattle, and deer throng to the rivers in such numbers that the foremost of the crowd are pushed into the stream by the pressure of others behind, and are sometimes carried away by thousands and 
drowned.* In their eagerness to drink the saline waters and lick the salt, the heavy mastodons and elephants seem in like manner to have pressed upon each other, and sunk in these soft quagmires of Kentucky.

The greater proportion both of the entire skeletons of extinct animals, and the separate bones, have been taken up from black mud, about twelve feet below the level of the creek. It is supposed that the bones of mastodons found here could not have belonged to less than one hundred distinct individuals, those of the fossil elephant (E. primigenius), to twenty, besides which, a few bones of a stag, horse, megalonyx, and bison, are stated to have been obtained. Whether the common bison, the remains of which I saw in great numbers in a superficial stratum recently cut open in the river's bank, has ever been seen in such a situation as to prove it to have been contemporaneous with the extinct mastodon, I was unable to ascertain. In regard to the horse, it may probably have differed from our Equus caballus as much as the zebra or wild ass, in the same manner as that found at Newberne in North Carolina appears to have done. (See p. 131.) The greatest depth of the black mud has not been ascertained; it is composed chiefly of clay, with a mixture of calcareous matter and sand, and contains 5 parts in 100 of sulphate of lime, with some animal matter. (Cuvier, Oss. Foss., tom. i., p. 216.) Layers of gravel occur in the midst of it at various depths.

* Darwin's Journal, p. 156; Sir W. Parish's Buenos Ayres, pp. 151 and 371. 
In some places it rests upon the blue limestone. The only teeth which I myself procured from collectors un the spot, besides those of the buffalo, were recognized by Mr. Owen as belonging to extremely young mastodons. From the place where they were found, and the rolled state of some of the accompanying bones, I suspected that they had been washed out of the soil of the bogs above by the river, which often changes its course after floods.

Mr. Cooper of New York, who has given the fullest account of the fossils of this place, says, that the remains of reeds and freshwater mollusca accompany the bones; but he names no species of shells. Mr. Anthony and I were therefore diligent in our search for shells in pits which happened to have been recently laid open by collectors of fossil bones; and we soon obtained a small Ancylus and Cyclas. Afterwards, in the most eastern marsh, in the middle of which a powerful spring throws up beech nuts and shells from the mud below, we found two species of Melania known as recent, Physa heterostropha, Cyclas similis, C. dubia? (and another species, not known to naturalists here), Pisidium (supposed to agree with one from Lake Erie), Ancylus (not known), and fragments of Unio; also the following land shells;-Helix solitaria (with bands of colour not effaced), $\boldsymbol{H}$. alternata, $\boldsymbol{H}$. clausa, $\boldsymbol{H}$. fraterna, and Pupa armifera. As new terrestrial and freshwater shells are occasionally added to the recent American fauna, I think it very probable that all the fourteen species which we met with, and which, I believe, co-existed with the mastodon, are still living, though 
perhaps not all of them in the immediate neighbourhood.

It is impossible to view this plain, without at once concluding that it has remained unchanged in all its principal features from the period when the extinct quadrupeds inhabited the banks of the Ohio and its tributaries. But one phenomenon perplexed us much, and for a time seemed quite unintelligible. On parts of the boggy grounds, a superficial covering of yellow loam was incumbent on the dark-coloured mud, containing the fossil bones. This partial covering of yellow sandy clay was at some points no less than fifteen or twenty feet thick. Mr. Bullock passed through it when he dug for fossil remains on the left bank of the creek, and he came down to the boggy grounds with bones below. We first resorted to the hypothesis that the valley might have been dammed up by a temporary barrier, and converted into a lake; but we afterwards learnt, that although the Ohio is seven miles distant by the windings of the creek, there being a slight descent the whole way, yet that great river has been known to rise so high as to flow up the valley of Big Bone Creek, and, so late as 1824, to enter the second story of a house built near the springs. The level of the Licks above the Ohio is about fifty feet, the distance in a straight line being only three miles. At Cincinnati the river has been known to rise sixty feet above its summer level, and in the course of ages it may occasionally have risen higher. It may be unnecessary, therefore, to refer to the general subsidence before alluded to (probably an event of a much older date), in order to account. for the patches of superficial silt last described. 
After spending the day in exploring the Licks, we were hospitably received at the house of a Kentucky proprietor a few miles distant, whose zeal for farming and introducing cattle of the "true Durham breed," had not prevented him from cultivating a beautiful flower garden. We were regaled the next morning at breakfast with an excellent dish of broiled squirrels. There are seasons when the grey squirrel swarms here in such numbers, as to strip the trees of their foliage, and the sportsmen revenge themselves after the manner of the Hottentots, when they eat the locusts which have consumed every green thing in Southern Africa.

We then returned by another route through the splendid forest, and re-crossed the Ohio. The weather was cool, and we saw no fire-flies, although I had seen many a few days before, sparkling as they flitted over the marshy grounds bordering the Ohio, in my excursion up the river to Rockville.

Among the inquiries which can hardly fail to awaken the curiosity of a geologist who explores this region, one of the most natural relates to the relative age of the northern drift, and the deposits containing the remains of the mastodon and elephant, whether at Big Bone Lick, or in the higher terrace $(b$, fig. 9) at Cincinnati. In my journey, some days afterwards, from the Ohio river to Cleveland on Lake Erie, I had not proceeded twenty-five miles to the northward before I again found myself in a country covered with northern drift, of which I had lost sight for many weeks previously. The first patches which I observed were about five miles N.E. of the town of Lebanon, after which I saw it in great 
abundance at Springfield, with large blocks and boulders of gneiss, reddish syenite, quartzite, and hornblende rock, all of which must have come from the north side of Lake Erie. The Ohio river, therefore, in the north latitude $40^{\circ}$ and $41^{\circ}$, seems to mark the southern limit of the drift in this part of North America, although some scattered blocks have gone farther, and reached Kentucky.

I was also told that a boulder of gneiss, twelve feet in diameter, has been found resting on the upper terrace $(b, f i g .9)$, four miles north of Cincinnati, and that fragments of granite, in a similar situation, have been met with at that city itself. These may possibly have been brought into their present position since the period of the deposition of the principal mass of northern drift; for, although I could not obtain sufficient data for forming an accurate opinion as to the relative age of the drift, and the beds containing the bones of mastodon and elephant, whether in the upper terrace above alluded to, or in the licks of Kentucky, I incline to believe the drift, as a whole, to be the older of the two formations. The swamps of the Big Bone Licks have the same intimate relation to the present superficial geography of the district, as have those marshes and alluvial deposits before described in New York, as containing the remains of mastodon and recent shells, which are decidedly more modern than the drift and its erratic blocks. (Vol. I., pp. 18, 20, and 54.) 


\section{CHAPTER XVIII.}

Cincinnati.-Journey across Ohio to Cleveland.-New Clearings.-Rapid Progress of the State since the year 1800.Increase of Population in the United States.-Political Discussions.-German and Irish Settlers.-Stump Oratory.Presidential Elections.-Relative Value of Labour and Land.

THE pork aristocracy of Cincinnati does not mean those innumerable pigs which walk at large about the streets, as if they owned the town, but a class of rich merchants, who have made their fortunes by killing annually, salting, and exporting, about 200,000 swine. There are, besides these, other wealthy proprietors, who have speculated successfully in land, which often rises rapidly in value as the population increases. The general civilisation and refinement of the citizens is far greater than might have been looked for in a State founded so recently, owing to the great number of families which have come directly from the highly educated part of New England, and have settled here.

As to the free hogs before mentioned, which roam about the handsome streets, they belong to no one in particular, and any citizen is at liberty to take them up, fatten, and kill them. When they increase too fast, the town council interferes, and sells off some of their number. It is a favorite amusement of the boys to ride upon the pigs, and we were shown one sagacious old hog, who was in the habit of lying down as soon as a boy came in sight.

voL. II. 
May 29th.-We left Cincinnati for Cleveland on Lake Erie, a distance of 250 miles, and our line of route took us through the centre of the State of Ohio, by Springfield, Columbus, Mount Vernon, and Wooster, at all which places we slept, reaching Cleveland on the fifth day.

In our passage through Ohio, we took advantage of public coaches only when they offered themselves in the day-time, and always found good private carriages for the rest of the way. If some writers, who have recently travelled in this part of America, found the fatigue of the journey excessive, it must have arisen from their practice of pushing on day and night over roads which are in some places really dangerous in the dark. On our reaching a steep hill north of Mount Vernon, a fellow-passenger pointed out to me a spot where the coach had been lately upset in the night. He said that in the course of the last three years he had been overturned thirteen times between Cincinnati and Cleveland, but being an inside passenger had escaped without serious injury.

In passing from the southern to the northern frontier of Ohio, we left a handsome and populous city and fine roads, and found the towns grow smaller and the high road rougher, as we advanced. When more than half way across the State, and after leaving Mount Vernon, we saw continually new clearings, where the felling, girdling, and burning of trees was going on, and where oats were growing amidst the blackened stumps on land which had never been ploughed, but only broken up with the harrow. The carriage was then jolted for a short space over a 
corduroy road, constructed of trunks of trees laid side by side, while the hot air of burning timber made us impatient of the slow pace of our carriage. We then lost sight for many leagues of all human habitations, except here and there some empty wooden building, on which "Mover's House" was inscribed in large letters. Here we were told a family of emigrants might pass the night on payment of a small sum. At last the road again improved, and we came to the termination of the table land of Ohio, at a distance of about sixteen miles from Lake Erie. From this point on the summit of Stony Hill we saw at our feet a broad and level plain covered with wood; and beyond, in the horizon, Lake Erie, extending far and wide like the ocean. We then began our descent, and in about three hours reached Cleveland.

The changes in the cundition of the country which we had witnessed are illustrations of the course of events which has marked the progress of civilisation in this State, which first began in the south, and spread from the banks of the Ohio. At a later period, when the great Erie canal was finished, which opened a free commercial intercourse with the river Hudson, New York, and the Atlantic, the northern frontier began to acquire wealth and an increase of inhabitants. Ports were founded on the lake, and grew in a few years with almost unparalleled rapidity. The forest then yielded to the axe in a ne"N direction, and settlers migrated from north to south, leaving still a central wilderness between the Ohio and Lake Erie. This foresi might have proved for many generations a serious obstacle to the progress 
of the State, had not the law wisely provided that all non-resident holders of waste lands should be compelled to pay their full share of taxes laid on by the inhabitants of the surrounding districts for new schools and roads. If an absentee is in arrear, the sheriff seizes a portion of his ground contiguous to a town or village, puts it up for auction, and thus discharges the debt, so that it is impossible for a speculator, indifferent to the local interests of a district, to wait year after year, until he is induced by a great bribe to part with his lands, all ready communication between neighbouring and highly cultivated regions being in the mean time cut off.

Ohio was a wilderness exclusively occupied by the Indians, until near the close of the last century. In 1800 its population amounted to 45,365 , in the next ten years it had increased five-fold, and in the ten which followed it again more than doubled. In 1840 it had reached $1,600,000$ souls, all free, and almost without any admixture of the coloured race. In this short interval the forest had been transformed into a land of steamboats, canals, and flourishing towns; and would have been still more populous had not thousands of its new settlers migrated still farther west into Indiana and Illinois. A portion of the pub. lic works which accelerated this marvellous prosperity, were executed with foreign capital, but the interest of the whole has been punctually paid by direct taxes. There is no other example in history, either in the old or new world, of so sudden a rise of a large country to opulence and power. The State contains nearly as wide an extent of arable land as England, all of moderate elevation, so rich in its 
alluvial plains as to be cropped thirty or forty years without manure, having abundance of fine timber, a temperate climate, many large navigable rivers, a ready communication through Lake Erie with the north and east, and by the Ohio with the south and west, and, lastly, abundance of coal in its eastern counties.

I am informed that, in the beginniug of the present year (1842), the foremost bands of emigrants have reached the Platte River, a tributary of the Missouri. This point is said to be only half way between the Atlantic and the Rocky Mountains, and the country beyond the present frontier is as fertile as that already occupied. De Tocqueville calculated that along the borders of the United States, from Lake Superior to the Gulf of Mexico, extending a distance of more than 1200 miles as the bird flies, the whites advance every year at a mean rate of seventeen miles; and he truly observes that there is a grandeur and solemnity in this gradual and continuous march of the European race towards the Rocky Mountains. He compares it to " a deluge of men rising unabatedly, and daily driven onwards by the hand of God."**

When conversing with a New England friend on the progress of American population, I was surprised to learn, as a statistical fact, that there are more whites now living in North America than all that have died there since the days of Columbus. It seems probable, moreover, that the same remark may hold true for fifty years to come. The census has been very carefully taken in the United States since

* Democracy in America, vol. ii., ch. x, sect. 4. 
the year 1800, and it appears that the ratio of increase was 35 per cent. for the first decennial periods, and that it gradually diminished to about 32 per cent. in the last. From these data, Professor Tucker estimates that, in the year 1850 , the population will amount in round numbers to 22 millions, in 1860 to 29 millions, in 1870 to 38 millions, in 1880 to 50 millions, in 1890 to 63 millions, and in 1900 to 80 millions.

The territory of the United States is said to amount to one-tenth, or at the utmost to one-eighth of that colonised by Spain on the American continent. Yet in all these vast regions conquered by Cortes and Pizarro, there are considerably less than two millions of people of European blood, so that they scarcely exceed in number the population acquired in about half a century in Ohio, and fall far short of it in wealth and civilisation.

We were perfect strangers in our tour through Ohio, and, when at inns and in public conveyances, had many opportunities of hearing lawyers, merchants, farmers, and labourers, conversing freely and unreservedly together. I have generally abstained from retailing such gossip, reflecting how small would be the value of the opinions which an American could derive from a similar source, or from talk overheard in an English railway or steamboat. I shall, however, depart slightly from my rule on this occasion, as my readers may, perhaps, be amused as I was, and will abstain from drawing general conclusions from the conversation of persons whom chance has thrown in the traveller's way.

As soon as we were recognized to be foreigners, 
we were usually asked whether we had made up our minds where we should settle. On our declaring that, much as we saw to like and admire in America, we had no intention of exchanging our own country for it, they expressed surprise that we had seen so many States, and had not yet decided where to settle. Nothing makes an English traveller feel so much at home as this common question. You have arrived at the domain of a rich and hospitable host, who is ready to welcome you, and where there is ample room and accommodation for all. Some of the more highly educated class, especially the lawyers, expressed their alarm at the growing strength of the democratic party in Ohio, owing to the influx of Irish and German labourers, nearly all Roman Catholics, and very ignorant. These new comers, they said, had lately turned the elections against a majority of native Americans, their superiors in wealth and mental cultivation. They also complained that many settlers of German origin from Pennsylvania were opposed to all improvement, and unwilling to be taxed for new schools, canals, and roads. They were indifferent to the speedy arrival of letters and daily newspapers, and other advantages, for which the New Englanders and the Scotch and English Protestants would pay most cheerfully. Yet they allege that these same Germans, opposed as they are to all useful innovations, are in the habit of giving their votes to demagogues, who are prepared to plunge the country into the most headlong career of political changes.

A thriving farmer, who entered the coach at Wooster, spoke vehemently against the new tariff, 
which, he said, would sacrifice the agriculturists of the West to the New England manufacturers, who meant to compel them to buy their home-made goods at a high price, while the raw produce of Ohio and the West would be shut out from the British market. $\mathrm{He}$ also boasted to me of the advantages they enjoyed in the U.S., commiserating the lot of the inass of the people in the old country, deprived of their political rights, and exposed to the tyranny and oppression of the rich. By way of drawing him out, I told him how I had found the day before a minister preaching in Welsh to a congregation of three hundred persons in the town of Columbus-that these and other poor settlers, Irish and German, were ignorant of the American laws and institutions, and wholly uneducated. Ought they to be permitted to turn the elections, as I was told they had recently done in Ohio? On this he poured forth an oration on the equality of the rights of all men, on the invidious distinctions some desired to establish between the franchise of old and new settlers, on the policy of welcoming new comers when the population was sparse, on the advantages of common schools, and, lastly, on the evil of endowing universities, which he said were "hot-beds of aristocrats." While descanting on these and other topics, the tone of his voice grew louder and louder as his warmth increased, and when he left the public coach, a lawyer of Ohio congratulated me that I could now understand what is meant in the United States by "stump oratory," or that kind of declamation which is addressed by a candidate for popular favour from the stump of a tree in a new clearing. 
On another occasion, the respective merits of $\mathrm{Mr}$. Van Buren, Mr. Clay, and others, were canvassed, and an animated discussion took place on their relative claims to fill the presidential chair at the next general election. I expressed surprise that, as there were still three years to run of Mr. Tyler's official career, they should be mooting this question already. The whole country had been so recently convulsed by the severe contest between Harrison and Van Buren, in which parties had been so nearly balanced, that it was surely inexpedient that the minds of the people showld be again excited and unsettled. I enlarged on the superior advantages of an hereditary monarchy, as preventing the recurrence of such dangerous agitation, and was prepared for a retaliatory attack upon the kingly office, and a eulogy on the superiority of the American constitution. But Americans at home, however loyal and patriotic, and as little disposed to change their form of government for a monarchy as we are to turn republicans, are, nevertheless, by no means optimists. When they travel in England, they acquire a habit of standing on the defensive, from hearing John Bull object to everything in which their laws and institutions may happen to differ from his own. But in the United States, I frequently heard politicians deplore the progress of democracy, argue that the president ought to be elected for six years instead of four, that he should not be re-eligible, that there should be no veto, and contend for other organic changes. In reply to my sally, one of the party, who had previously expressed his fears that General Harrison's death would lead to the democratic party regaining their 
ascendancy, remarked, " The most disastrous periods, sir, in your history, were the wars of a disputed succession. We are always engaged in a civil war of this kind." By way of consolation, I reminded him that, at all events, there had been less bloodshed in their battles for the chief magistracy than in our contests for the rightful heirs to a throne. He replied, "Yes, there has been less destruction of the body, but not of the soul. A president who has 60,000 places in his gift holds in his hands far greater means of bribery and corruption than did your Harry the Eighth, even after he had seized upon the property of the monasteries."

One of my travelling companions in Ohio assured me that agricultural labourers from the Lowlands of Scotland were the best settlers of all who came direct from Europe. Some of these had arrived with a large family, and with no money even to buy the implements of husbandry, and had in twelve years become the owners of 300 acres of cleared land, in which the log-house was replaced by a neat farm building, called a frame-house, with a small garden attached to it. They laugh here at the common error into which new settlers fall, who possess some money, and have been accustomed to English farming, especially their diligence in uprooting stumps, which have so slovenly an appearance. This practice seems to be in their eyes the most unequivocal test of extreme ignorance of the relative value of labour and land in a new country. Foreigners who have a small capital should always settle in districts which have been already cleared, and broken up by the plough. 


\section{CHAPTER XIX.}

Cleveland.--Ridges of Sand and Gravel along the Southern Coast of Lake Erie.-Their Origin.-Fredonia, Streets lighted with natural Gas.-Falls of Niagara.-Burning Spring.-Passing behind the Falls.-Daguerreotype of the Falls.-Boulder Formation of Whirlpool, and Valley of St. David's.-Glacial polishing and Furrows.--Influence of Icebergs on Drift.

June 3, 1842.-The morning after my arrival at Cleveland, Dr. Kirtland, the zoologist, took me to Rockport, about four miles to the west, and afterwards to the ravine of a torrent called the Rocky River, about six miles farther, in the same direction, that I might examine in both places what are here called the Lake Ridges. Like the "ridge road" of Lake Ontario before described (Vol. I., p. 24), they resemble ancient beaches, running parallel to the shores of Lake Erie, and being composed of sand and gravel.

At the point which I first visited, in the town of Rockport, Lake Erie is bounded by a perpendicular cliff (A, fig. 10), about seventy-five feet high, at the base of which the water is so deep, that, in some places, it can only be approached in a boat. Horizontal beds of shale, with some layers of sandstone, appear cut off abruptly in the face of this cliff, all referable to the Hamilton group, No. 10 of Map Pl. II., or the lowest part of the Devonian series (F). Proceeding from the summit of the cliff inland, we find the surface of the country covered with clay $(b)$, 
sloping gently, so that, in half a mile, there is a rise of about forty feet, and we then come to the bottom of the first or northernmost ridge $(c)$, which is about fifteen feet high, rising at an angle of about $12^{\circ}$, both on its northern and southern slope. Between this and the next ridge $(d)$, which is about half a

North

Fig. 10.

South

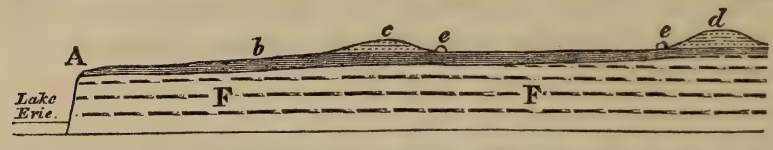

"Lake Ridges" near Clevcland, Ohio.

mile distant, extends a line of swamps and marshes, some of them several hundred acres in extent. Two other parallel ridges of sand and gravel are observable still farther inland or southwards, the distance of each varying greatly according to the general slope of the land, for the same ridge occasionally approaches within a mile of the shore at one point, and recedes to the distance of eleven miles from it at another, apparently preserving everywhere the same level.

Boulders of granite, some of them three feet in diameter, which must have come from the north side of Lake Erie, are scattered sparingly here and there as at $e, f i g .10$. I could not obtain any fossil shells from any of these ridges, although some are said to have been found, together with fragments of wood, similar to those now thrown up on the beach of the lake. The shells might at once decide the point whether the ridges are of marine or freshwater origin. If this were settled, another and distinct ques- 
tion would still remain; namely, whether they were for the most part formed at first under water, like sand-bars at the mouth of rivers; or were thrown up by the waves on the margins of ancient sheets of water, in the manner of beaches.

The section which I saw on the banks of the Rocky River appeared to me to favour the theory of the subaqueous origin of the ridges. This torrent, about a mile and a half above its mouth, flows in a narrow ravine, scarcely more than thirty yards wide, with perpendicular cliffs on each side, 110 feet high. When we arrive at the point where the ravine intersects the second of the Rockport ridges before alluded to $(d, f i g .10)$, we see the river-cliff suddenly heightened by the addition, for a short space, of a bank of sand and gravel, about 30 feet high, the pebbles in the ridge being rounded like those on the lake shore, and proving that the bank was never a mere dune of blown sand.

If we imagine bars or banks of sand and pebbles to have been formed in succession near the shore in shallow water, and then cut through by torrents when the land was elevated, we can explain the abrupt manner in which the ridge determinates on each side of a ravine evidently excavated by the torrent in soft shale since the emergence of the strata. But it is difficult to imagine how an ancient beach, formed where a stream entered a lake or sea, could have been so straight and continuous, and so little modified and rounded off in its outline conforming to the shape of the small bay, which must have existed at the entrance of a stream. It will be unnecessary, however, to dwell longer on this question at present,

VOL. II. 
as I shall resume the subject when discussing the nature and origin of the "lake ridges" near Toronto.

The town of Cleveland is built on a terrace of stratified clay and sand, the height of which is 103 feet above the lake. Its depth is unknown, the fundamental Devonian (or Hamilton) strata being concealed here, so that the newer deposit exclusively occupies the lake shore for forty miles. As several rivers besides the Cuyahoga of Cleveland cut winding courses through this terrace, we may presume that these rivers existed when the water stood 100 feet higher relatively to the land. If so, we seem to have here an upraised delta formed of the materials brought down by streams before the waters had sunk to their present relative level. The nature of the sand and clay is such as rivers might have washed down from the land above, but no shells have been discovered, although diligently searched for, during the excavation of a ship canal and other works in the town. The tooth of a mastodon, however, was shown me as having been found low down in the clay.

June 5.-Sailed in a steamboat to Fredonia, a town of 1200 inhabitants, with neat white houses, and six churches. The streets are lighted up with natural gas, which bubbles up out of the ground, and is received into a gasometer, which I visited. This gas consists of carburetted hydrogen, and issues from a black bituminous slate, one of the beds of the Hamilton group of the New York geologists, or part of the Devonian formation of Europe. The lighthouse-keeper at Fredonia told me that, near the shore, at a considerable distance from the gasometer, he 
bored a hole through this black slate, and the gas soon collected in sufficient quantity to explode, when ignited.

There is a ridge of sand at Fredonia, as at many other places, between Cleveland and the outlet of the Niagara from Lake Erie, but I tried in vain to identify the ridges with those seen by me at Rockport, and could not discover that their heights, as estimated by residents, agreed at different places. Some of them, indeed, according to Mr. Whittlesey, the engineer, decline in altitude as they are traced eastward.

We next reached Buffalo, and found so many new buildings erected since the preceding autumn, and new shops opened, that we were amazed at the progress of things, at a time when all are complaining of the unprecedented state of depression under which the commerce and industry of the country are suffering.

At the Falls of Niagara, where we next spent a week, residing in a hotel on the Canada side, I resumed my geological explorations of last summer. Every part of the scenery, from Grand Island above the Falls to the Ferry at Queenstown, seven miles below, deserves to be studied at leisure.

We visited the "burning spring" at the edge of the river above the rapids, where carburetted hydrogen, or, in the modern chemical phraseology, a light hydro-carbon, similar to that before mentioned at Fredonia, rises from beneath the water out of the limestone rock. The bituminous matter supplying this gas is probably of animal origin, as this limestone is full of marine mollusca, crustacea, and corals, with- 
out vegetable remains, unless some fucoids may have decomposed in the same strata. The invisible gas makes its way in countless bubbles through the clear transparent waters of the Niagara. On the application of a lighted candle, it takes fire, and plays about with a lambent flickering flame, which seldom touches the water, the gas being at first too pure to be inflammable, and only obtaining sufficient oxygen after mingling with the atmosphere at the height of several inches above the surface of the stream.

At noon, on a hot summer's day, we were tempted, contrary to my previous resolution, to perform the exploit of passing under the great sheet of water between the precipice and the Horse-shoe Fall. We were in some degree rewarded for this feat by the singularity of the scene, and the occasional openings in the curtain of white foam and arch of green water, which afford momentary glimpses of the woody ravine and river below, fortunately for us lighted up most brilliantly by a midday sun. We had only one guide, which is barely sufficient for safety when there are two persons, for a stranger requires support when he loses his breath by the violent gusts of wind dashing the spray and water in his face. If he turns round to recover, the blast often changes in an instant, and blows as impetuously against him in the opposite direction.

The Falls, though continually in motion, have all the effect of a fixed and unvarying feature in the landscape, like the two magnificent fountains in the great court before St. Peter's at Rome, which seem to form as essential a part of one architectural whole as the stately colonnade, or the massive dome itself. 
However strange, therefore, it may seem, some Daguerreotype representations of the Falls have been executed with no small success. They not only record the form of the rocks and islands, but even the leading features of the cataract, and the shape of the clouds of spray. I often wished that Father Hennepin could have taken one of these portraits, and bequeathed it to the geologists of our times. It would have afforded us no slight aid in our speculations respecting the comparative state of the ravine in the 19th and 17th centuries.

After one or two warm days, the weather became unusually cold for the month of June, with occasional frosts at night, and the humming-birds which we had seen before reaching Buffalo appeared no more during our stay here.

In my visits to Grand Island, Lewiston, and St. Catherines, I made some of the observations already alluded to in the first volume (ch. ii., p. 27) ; and I shall now confine myself to remarks on the connection of certain strata of drift which appear at the Whirlpool, and similar deposits observable in the valley of St. David's, about three miles west of Queenstown, where there is an opening in the escarpment, as shown in the bird's-eye view (Pl. I.), and in the map of the Niagara district (Pl. III.). In the former view (Pl. I.), a small chasm is introduced on the left bank of the Niagara at the whirlpool, to mark the only spot where the continuity of the older formations (the limestone, shale, and subjacent rocks) is broken between the Falls and Queenstown. This interruption occurs precisely opposite the summerhouse (e. fig. 11). 
Fig. 11.

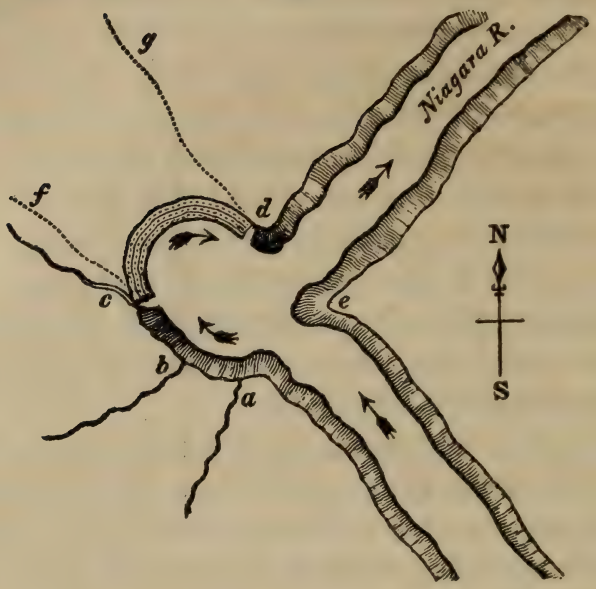

Course of the Niagara at the Whirlpool.

$a, b$. Streamlets which are thrown in cascades over the limestone precipice, after cutting through superficial red drift, twenty-five feet thick.

c. Bowman's Run.

d. Small gulloy, between which and $c$ the cliffs consist of drift.

c. Summer house, where sand with fresh-water shells rests on the top of the precipice. See fig. 3 , Vol. I., p. 40.

$f, g$. Probable course of the ancient valley, now filled with drift.

The river cliff, from $c$ to $d$, or for a distance of about 170 yards, on the northern side of the whirlpool, consists exclusively of strata of sand, loam and gravel; the latter in parts cemented together into a conglomerate, and all belonging to the drift or boulder formation. The visible thickness of this modern deposit is about 300 feet, but we know not to what depth it may extend below the level of the Niagara. It appears clearly that there was here an original valley, which was afterwards completely filled up with stratified drift. The same red clay which 
spreads far and wide over the limestone platform, forms the uppermost stratum of the mass, the occurrence of which, at this point, had been overlooked by geologists, until $\mathrm{Mr}$. Hall and I observed it in 1841. He immediately suggested to me that it might be connected with the opening in the escarpment at St. David's, about three miles to the northwest, which I determined to examine the year after.

On a close inspection of the drift in the cliffs between $c$ and $d$, we find it to be composed at the top of red clay, from twenty to thirty feet thick, below which is a conglomerate, including boulders of granitic and trappean rocks, of northern origin, mixed with fragments of the Niagara limestone. One angular block of the latter is no less than fifteen feet in diameter, having been evidently detached from the original wall of the chasm during its denudation. Below this come beds of white sand and loam, to which succeed gravel cemented into a conglomerate by carbonate of lime, the pebbles being of sandstone, limestone, and hornblende rock. Under this conglomerate are laminated clays, being the lowest visible strata.

Ascending the steep bank formed of these materials, we soon reach the general level of the tableland, and pass over it for two miles before we begin to enter the depression, which, deepening gradually, carries us down to St. David's. This valley is entirely excavated in the boulder formation, and we may infer that the latter maintains its full depth between St. David's and the whirlpool, from sections obtained in sinking wells in the intervening township 
of Stamford, where a great thickness of drift was passed through.

In the bird's-eye view (Pl. I., Vol. I.), the valley of St. David's is represented, for want of more space, as of small width ; but it is, in fact, about two miles broad at its mouth, so that it bears no resemblance to the deep narrow chasm in which the Niagara flows. One end of it seems to have terminated originally in an angle at the point where the whirlpool is now situated; and the sections laid open in the gulleys ( $c$ and $d, f i g .11$ ) show that the walls of the ancient hollow were not perpendicular, but consisted of a succession of precipices and ledges. I was informed that, near St. David's, an outlier of quartzose sandstone, $\left(a^{\prime}, f i g .12\right)$, was found by boring through the drift, which may, therefore, have projected like an island in the middle of the original valley or channel.

The accompanying diagram will, probably, convey a correct notion of the manner in which the drift rests upon the older rocks near the northwestern end of the valley of St. David's. The outline of the older formation given in this transverse section is, in fact, the same as that presented by the same rocks in those parts of the escarpment east and west of Lewiston and Queenstown, where the face of the cliff is not masked by drift.

I shall afterwards describe cavities, or ancient valleys, intersecting the old Silurian rocks near Quebec, which have been filled up with transported materials, in which marine shells of recent species, and of a northern or arctic character, have been discovered. These shells have also been found in the drift of the 
East.

Fig. 12.

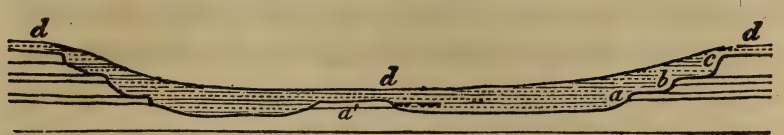

Supposed section of drift and subjacent rocks in valley of St. Davids.

a. Ledge of quartzose (Medina) sandstone.

b. Ledge of Clinton limestone.

c. Platform of Niagara limestone.

d. General covering of drift or boulder formation.

valley of the St. Lawrence, at elevations of more than $\mathbf{5 0 0}$ feet above the level of the sea, or nearly as high as Lake Erie, so that I consider it to be a mere local accident that none of the same are preserved, or have yet been met with in the Niagara district.

Professor Fmmons has shown that, on the removal of the clay and sand containing those marine shells in the valley of Lake Champlain, the rocks beneath are polished and furrowed, and similar phenomena are observed in the region now under consideration between Lakes Erie and Ontario. If the reader will glance at the frontispiece (Pl. I.), he will see in the distance a zone of country (No. 1) bounding Lake Erie, part of which consists of an upper Silurian limestone, called in New York the Corniferous. It occurs at Black Rock among other places (see Map, Pl. III.). It is very hard, contains many corals, and has nodules of flint or chert dispersed through it in horizontal beds. The upper surface of this rock, when the boulder clay is removed, appears smoothed or polished, and usually scored with long parallel furrows. But the nodules of chert, although much rubbed down and worn, stand out slightly in relief, while narrow elongated ridges of limestone are seen 
extending from the southern end of each nodule, marking the space where the softer rock has been protected for a short distance from the triturating action which ground down the whole.

Mr. George E. Hayes of Buffalo showed me large specimens of the polished rock, on which these markings were conspicuous ; and he and Mr. Haskin have ascertained that the general direction of the grooves in this region is N.E. and S.W., or N. $35^{\circ}$ E. They are traced over the broad platform of the Niagara limestone No. 3 (see Frontispiece and Map, Pl. III.), retaining the same course wherever the drift is removed; and, what is still more remarkable, as Mr. Hall pointed out to me, near Lewiston and Lockport, they are imprinted at different levels on the projecting shelves formed by the more solid rocks of the great escarpment. Suppose, for example, the drift $d$ (fig. 12, p. 81) to be removed from the ledge of quartzose sandstone, $a$, and from the surface of the upper edge of Clinton limestone, $b$, and from $c$, - we should find everywhere grooves running nearly in the direction N.E. and S.W.

Some geologists have considered these facts as very difficult to reconcile with the glacial theory. To me they appear to indicate the following succession of events. First, the country represented in the frontispiece (Pl. I.) acquired its present geographical configuration, so far as relates to the outline of the older rocks, under the joint influence of elevatory and denuding operations. Secondly; a gradual submergence then took place, bringing down each part of the land successively to the level of the waters, and then to a moderate depth below them. 
Large islands and bergs of floating ice came from the north, which, as they grounded on the coast and on shoals, pushed along all loose materials of sand and pebbles, broke off all angular and projecting points of rock, and when fragments of hard stone were frozen into their lower surfaces, scooped out grooves in the subjacent solid strata. The sloping beach, as well as the level bottom of the sea, and even occasionally the face of a steep cliff, might all be polished and grooved by this machinery; but no flood of water, however violent, or however great the quantity of detritus, or size of the rocky fragments swept along by it, could produce straight, parallel furrows, such as are everywhere visible in the district under consideration.

Mr. John L. Hayes, in an able paper recently published, on the influence of icebergs upon drift, has shown, from a great variety of testimony, that they have a remarkable steadiness of motion, in consequence of the larger portion of their bulk being deep under water, so that they are not perceptibly moved by the winds and waves, even in the strongest gales. Many had supposed that the magnitude attributed to ice-islands by unscientific navigators had been exaggerated, but it appears that their estimate of their dimensions has rather fallen within than beyond the truth. Many of the icebergs, carefully measured by the officers of the French exploring expedition of the Astrolabe, were between 100 and 225 feet high, and from two to five miles in length. Captain D'Urville ascertained one of these bergs, floating in the Southern Ocean, to be thirteen miles long, and a hundred feet high, with walls per- 
fectly vertical. The submerged portions of such islands must, according to the weight of ice relatively to sea-water, be from six to eight times more considerable than the part which is visible, so that the mechanical power they may have exerted when fairly set in motion must be prodigious.*

To return to the succession of geological changes which immediately preceded the present period in the Niagara district:-Thirdly, after the surface of the rocks had been smoothed and grated upon by the passage of innumerable icebergs, the clay, gravel, and sand of the drift were deposited, and occasionally fragments of rock, both large and small, which has been frozen into glaciers, or taken up by coast ice, were dropped here and there at random over the bottom of the ocean, wherever they happened to be detached from the melting ice. During this period of submergence, the valleys in the ancient rocks were filled up with drift, with which the whole surface of the country was over-spread. Finally; the period of re-elevation arrived, or of that intermittent upward movement, when the ridges to be described in the next chapter were formed in succession, and, when valleys, like that of St. David's, which had been filled up, were partially re-excavated.

* J. L. Hayes, Boston Journ. Nat. Hist., 1844. 


\section{(2) \\ CHAPTER XX.}

Mirage on Lake Ontario.-Toronto.-Excursion with Mr. Roy to examine the Parallel Ridges between Lakes Ontario and Simcoe.-Correspondence of Level in their Base-lines over wide Areas.-Origin of the Ridges.-Lacustrine Theory.Hypothesis of Sand-banks formed under Water.-Rapid Progress of the Colony.-British Settlers unable to speak English.

June 14, 1842.-From Queenstown we embarked in a fine steamer for Toronto, and had scarcely left the mouth of the river, and entered Lake Ontario, when we were surprised at seeing Toronto in the horizon, and the low wooded plain on which the town is built. By the effect of refraction, or " mirage," so common on this lake, the houses and trees were drawn up and lengthened vertically, so that I should have guessed them to be from 200 to 400 feet high, while the gently rising ground behind the town had the appearance of distant mountains. In the ordinary state of the atmosphere none of this land, much less the city, would be visible at this distance, even in the clearest weather.

Toronto contains already a population of 18,000 souls. The plain on which it stands has a gentle, and to the eye imperceptible, slope upwards from the lake, and is still covered, for the most part, with a dense forest, which is beginning to give way before the axe of the new settler. I found Mr. Roy, the civil engineer, expecting me, and started with him VOL. II. 
the morning after my arrival, to examine those ridges of sand and gravel, and those successive terraces, at various heights above the level of Lake Ontario, of which he had given an account in $\mathbf{1 8 3 7}$ to the Geological Society of London. No small curiosity was excited, when his paper was read, by his endeavour to explain the phenomena, by supposing the former existence of a vast inland sea of fresh water, the barriers of which were broken down one after another until the present chain of lakes alone remained.

We started at an early hour from Toronto on horseback, taking a direction due northwards through the forest, and after riding for a mile over what seemed a perfectly level plain, came to the first ridge, the base of which my companion informed me was 108 feet above Lake Ontario. This ridge rose abruptly with a steep slope towards the lake, and was from 20 to 30 feet high. Its base consisted of clay, and its sandy summit, covered with pines, might easily be traced eastward and westward by the distinctness of the narrow belt of fir-wood, on each side of which other kinds of timber flourished luxuriantly on the clayey soils.

Continuing our ride over the plain we arrived at the second ridge, a mile and a half farther inland, having its base 208 feet above the lake; this level, and the others afterwards to be mentioned, having been accurately ascertained by Mr. Roy when employed professionally in making measurements for several projected canals and railroads. The second ridge is a far more striking object than the first, being from 50 to $\mathbf{7 0}$ feet high above the flat and even ground on both sides of it. At its foot were a great 
number of boulders of rocks which, by their com. position, can be proved to have come from the north; and some few of which were perched on the summit of the ridge. Such transported fragments are rare on the soil between the ridges. Another ride of two miles and a half, in a northerly direction, brought us to the third ridge, five miles distant from the lakeshore, which was much less conspicuous than the preceding ones ; it was indeed, at the point where we crossed it, little more than a steep slope of ten feet, by which we mounted to a higher terrace. The surface of this terrace was only 80 feet above the base of the second ridge, so that the top of the latter, in those places where it is $\mathbf{7 0}$ feet or more in height, is nearly on a level with the bottom of the third ridge, or cliff.

In this manner we went on, passing one ridge or cliff after another, sometimes deviating from our course for several miles east and west, that my guide might point out to me the continuity of the ridges, and the uniformity of the level of their base-lines. This uniformity, however, though I have no doubt of its reality, I had no time to test by actual measurement. On tracing the same ridge for several miles east and west, I occasionally found it to vary greatly in height above the plain, and sometimes to divide into two. One of these sometimes formed a step immediately above the other, and sometimes diverged or branched off so as to form an upper and parallel ridge at some distance. They were all broken occasionally by deep narrow gaps, as I had observed in the Osars of Sweden.

I saw, on the whole, no less than eleven of these ridges, some of which might be called cliffs, or the 
abrupt terminations of terraces of clay, which cover everywhere the subjacent Silurian rocks to a great depth, and belong to the drift or boulder formation. The highest ridge is about 680 feet above Lake Ontario, the water-shed between that lake and Lake Simcoe being $\mathbf{7 6 2}$ feet high. There is then a descent of 282 feet from that summit level to the shores of Lake Simcoe, which is 42 miles from Lake Ontario. On this northern slope of 282 feet, Mr. Roy has traced several of the higher ridges, at levels precisely corresponding to those which I saw on the southern side. He also assures me that several of the ridges, which exceed in height the level of the table-land between Lakes Ontario and Erie, extend continuously to the northern shore of Lake Erie; and in another direction agree with ridges on the uplands bounding the valley of the Ottawa river.

The identification, however, of horizontal planes at points several hundred miles distant from each other, requires a nicety and exactness of trigonometrical measurement, which cannot as yet have been bestowed on this region; and when there are so many terraces at levels differing but slightly from each other, and some of them occasionally dividing into two, an upper and a lower shelf, they may easily be confounded at remote points.

I shall content myself with stating that, with the exception of the parallel roads or shelves in Glen Roy, and some neighbouring glens of the Western Highlands in Scotland, I never saw so remarkable an example of banks, terraces, and accumulation of stratified gravel, sand, and clay, maintaining, over wide 
areas, so perfect a horizontality, as in this district north of Toronto.

The hypothesis which attributes such appearances to the successive breaking down of the barriers of an ancient lake or ocean of fresh. water, has now been very generally abandoned, from the impossibility of conceiving where, in North America, as in the west of Scotland, the lands capable of damming up the waters to such heights could have been situated, or how, if they ever existed, they could have disappeared, while the levels of the ancient beaches remained undisturbed. In order to dispense with the necessity of barriers, we may assume that the successive ridges and cliffs were formed on the margin of the sea, which changed its level relatively to the land again and again, while a large part of the continent emerged gradually from the waters. In that case, we must imagine the movement of upheaval to have been intermittent, so that there were pauses during which the coast-line remained stationary for centuries, and when the waves had time to cut cliffs, or throw up beaches, or throw down littoral deposits and sandbanks near the shore.

This theory has been objected to on the ground of the great improbability of so vast an amount of vertical movement having been developed so uniformly over areas several hundred miles in diameter. In some parts of Sweden and Finland, however, there has been a near approach to an uniform upward movement of two or three feet in a century throughout wide areas within the historical era, and we know far too little of the laws governing subterranean movements, to entitle us to raise objections, on the ground 
that the observed phenomena would imply a regusarity in the process of upheaval, not in harmony with our pre-conceived notions.

Between the first and second ridges, north of Toronto, I saw a section 50 feet deep in the argillaceous deposit on which all the ridges rest, or in which cliffs, corresponding in level with some of the ridges, are cut. It consisted of blue clay in horizontal thin layers, with partings of yellow sand, and at the bottom yellow clay, with some interstratified layers of white clay. I observed no included boulders, but Mr. Roy has seen them at Toronto, where deep excavations were made for the foundations of buildings. They occurred near the junction of the clay and the subjacent rocks; and he remarked that the solid rocks, on the removal of the boulder formation, were polished and scored on the surface. I could find no shells either in the clay or in the ridges. I was informed, indeed, that marine shells had been met with in the clay, but, on inquiry, they turned out to be Silurian fossils, washed out of the ancient shales.

It will be seen from the above observations, that I consider the ridges and other marks of ancient waterlevels, between Toronto and Lake Simcoe, as referable, some of them to ancient beaches and lines of cliff formed on the margins of channels of the sea; others, including some of the loftiest ridges, as having originated in banks or bars of sand, formed, not at the extreme edge of a body of water, but at some distance from the shore, in proportion as the water obtained a certain shallowness by the upheaval of the land. 
It is well known that on many shelving coasts the breakers and tides give rise to banks of sand at no great distance from the beach. I learn from $\mathrm{Mr}$. Whittlesey that a bank of this kind has been formed for several miles along the southern shore of Lake Erie, near Cleveland, the origin of which he attributes in part to the reflux of the waves from the beach, by which pebbles and sand are swept out from the land.

Mr. Mather informs us that the great beach on the south coast of Long Island, in the State of New York, extends for a distance of 104 miles, with a breadth of from 100 to 1000 yards. For $\mathbf{7 0}$ miles it is separated from the mainland by, a continuous line of bays, which are between half a mile and six miles broad. "This great beach or bank forms a line of spits and low islands. One of the islands is about 25 miles long, with a breadth of a few hundred yards. They are all narrow and long, and when above the reach of the surf they are covered by a labyrinth of hillocks of drifted sand, imitating almost all the variety of form which snow-drifts present after a storm."* They consist, he adds, of the materials derived from the neighbouring cliffs of Long Island, which are undermined and destroyed by the waves. $\dagger$

Examples of similar banks parallel to the shore are cited by Mr. Darwin, in his work on Coral Reefs (p. 53). Capt. Grey also states that the west coast of Australia, in lat. $24^{\circ}$, is fronted by a sand bar about 200 yards in width, on which there is only two

* New York State Report, 1838, p. 130.

† Journal of Two Expeditions, \&c., vol. i., p. 369. 
feet of water ; but between it and the land the depth increases to two fathoms.**

At Bahia Blanca, in Brazil, Mr. Darwin observed a bar running parallel to the coast, on which they landed from the boats at low water, and then waded for a quarter of a mile to the shore. He has described a similar bar at Pernambuco, in Brazil, several leagues in length, in which the sand has been consolidated into a hard stone by calcareous matter. Within these bars currents are often seen to run strongly, caused by the water thrown over them by the waves when the tide is high. These waters run between the bar and the coast, until at length they find some breach in the bar by which they return to the sea.

In illustration of the ancient ridges or osars in Roxburghshire, Mr. David Milne, F.G.S., has described many examples of narrow sandbanks now existing off the coast of Britain, some 5, others $\mathbf{3 0}$ miles in length, with ten or twelve fathoms water between them and the neighbouring shore. $\dagger$

The existence of such bars near modern shores being ascertained, it follows that, if a coast be gradually upraised, many of them will be both formed and made to emerge in succession, all preserving the same general parallelism to each other which pre-

* Journal of Two Expeditions, \&c., vol. i., p. 369.

† See Trans. Roy. Soc. Edinb., vol. xv., p. 484, Jan. 1842. My paper, citing analogous cases, in explanation of similar geological phenomenon, was read at the same time to the Geological Society of London, without our having communicated together on the subject. See Abstract in Proceedings Geol. Soc., No. 92, p. 21, Jan. 4, 1843. 
vails in the ridges above the Canadian lakes. It is also clear that there will be swamps and ponds on the inland side of such upraised banks, representing the channels and lagoons which intervened originally between the bars and the mainland. There would also be occasional gaps in the ridges, some corresponding to original openings, through which the back water escaped, and others cut by torrents after the emergence of the land.

According to $\mathrm{Mr}$. Whittlesey, the base lines of several ridges east and west of Cleveland are not strictly horizontal, but inclined five feet, and sometimes more, in a mile. To account for this difference of level, it has been suggested that the upward movement of the land on the south side of Lake Erie may have been unequal, some parts being raised higher than others. But it deserves consideration whether the ridges, if some of them were bars or sandbanks, may not occasionally have varied in level from the first, according to the inequalities of the ground and the force of currents.

If we adopt the theory above set forth we must still conceive the banks to have become beaches as they emerged, or cliffs partially undermined by the waves, while in some cases they may have been entirely destroyed, of which I thought I saw indications when tracing the continuity of some ridges near Toronto.

In my ride with Mr. Roy through the forest we went about twenty miles due north of Toronto, besides making many detours. A more active scene of the progress of a new colony could scarcely be witnessed. We often came upon a party of survey- 
ors, or pioneers, tracing out a new line of road with the trunks of tall trees felled on every side, over which we had to leap our horses. Then we made a circuit to get to windward of some large stumps which were on fire, or, if we could find no pathway, hurried our steeds through the smoke, half suffocated and oppressed with the heat of the burning timber and a sultry sun. Sometimes we emerged suddenly into a wide clearing, where not a single clump of trees had been spared by the impatient and improvident farmer. All were burnt, not even a shrub remaining for the cattle and sheep, which, for want of a better retreat, were gasping under the imperfect shade of a wooden paling, called in America a Virginia, or snake fence.

The appearance of the country had been so entirely altered since Mr. Roy surveyed the ground two years before, and marked out the boundaries of the new settlements, that he lost his way while explaining to me the geology of "the ridges;" and after we had been on horseback for twelve hours we wandered about in a bright moonlight, unable to find the tavern where we hoped to pass the night. In the darker shade of the forest I saw many fire-flies; and my attention was kept alive, in spite of fatigue, by stories of men and horses swallowed up in some of the morasses which we crossed. I shall always, in future, regard a corduroy road with respect, as marking a great step in the march of civilisation; for greatly were we rejoiced when we discovered in the moonlight the exact part of a bog, over which a safe bridge of this kind had been laid down. At length we reached a log-house, and thought our 
troubles at an end. But the inmates, though eager to serve us, could not comprehend a syllable of our language. I tried English, French, and German, all in vain. Tired and disappointed, we walked to another log-house, a mile farther on, leading our weary horses, and then to others, but with no better success. Though not among Indians, we were as foreigners in a strange land. At last we stumbled, by good luck, upon our inn, and the next day were told that the poor settlers with whom we had fallen in the night before had all come from the British Isles in the course of the five preceding years. Some of them could speak Gaelic, others Welsh, and others Irish; and the farmers were most eloquent in descanting on their misfortune in having no alternative but that of employing labourers with whom they were unable to communicate, or remaining in want of hands while so many were out of work, and in great distress. For the first time I became fully aware how much the success and progress of a new colony depends on the state of schools in the mother country. 


\section{CHAPTER XXI.}

Kingston.-Montreal.-French Population and Language.Quebec._Soldiers.-Deserters._Three Rivers._Scotch Emigrants.-Distinctness of French and British Canadians.Large Military Foree.-American Sympathizers.-Geologic:sl Survey.-Analogy in Structure of Canada and Scandinasa. -Section at Falls of Montmorency.-Unconformable position of lowest Fossiliferous Sandstone to Gneiss.-Supposed Monument of the Commencement of the Organic World.-To what extent the Granitic Rocks are Primary.-Difficulty of establishing the Date of Metamorphic Action.-Two sources of popular error respecting the more abundant production of Hypogene Rocks at Remote Periods.

June 18th.-An excellent mail steam-packet carried us along the northern coast of Lake Ontario, from Toronto to Kingston, from whence I made a geological excursion to Gannanoquoi. From Kingston we then descended the St. Lawrence to Montreal. The scenery of the Thousand Islands and of the rapids of the St. Lawrence owe much of their beauty to the clearness of the waters, which are almost as green, and their foam as white, as at the Falls of Niagara.

On approaching Montreal we seemed to be entering a French province. The language and costume of the peasants and of the old beggars, the priests with their breviaries, the large crosses on the public roads, with the symbols of the Crucifixion, the architecture of the houses, with their steep roofs, large casement windows, and, lastly, the great Catholic cathedral rising in state, with its two lofty towers, carried back our thoughts to Normandy and Brittany, 
where we spent the corresponding season of last year. The French spoken in those provinces of the mother country is often far less correct, and less easy to follow, than that of the Canadians, whose manners are very prepossessing, much softer and more polite than those of their Anglo-Saxon fellowcountrymen, however superior the latter may be in energy and capability of advancement.

I was informed by a physician at Montreal that the English language has made great progress there within his recollection; and all agree that it would soon become still more general if the seat of government were transferred to that city, -a measure since realized, but which was then only beginning to be discussed (1842), and was exciting no small effervescence of party feeling. I was assured by many that it was the only step towards anglicising Lower Canada that would be popular with the French party. The country round Kingston must always be comparatively, barren, as much of the soil consists of granite and granitic detritus; and it could never become a large metropolis, such as Toronto might be made, or such as Montreal is even now.

Quebec, with its citadel and fortifications crowning the precipitous heights which overhang the St. Lawrence, and where the deep and broad river is enlivened with a variety of shipping, struck us as the most picturesque city we had seen since we landed in America. We were glad to meet with some old friends among the officers of the garrison, who accompanied us to the Falls of Montmorency, and other places in the neighbourhood. Their task in maintaining strict discipline in their corps, in preventing VOL. II. 
the desertion of soldiers, and keeping the peace along the frontier, has been more irksome than in quelling the rebellion. Those soldiers who have deserted to the States are said rarely to make good and thriving settlers; for they have been turned into such mere machines, into such creatures of routine, so exclusively trained for excellence in one art, that they want resources, and are singularly deficient in a virtue termed by the Americans "shiftiness," or the power of turning one's hand to anything and everything, for which the well-educated New-Engtand coloniser is celebrated.

On our way back from Quebec to Montreal, I stopped at Three Rivers to make a geological excursion to the Falls of Maskinongé, about ten miles northward of the St. Lawrence. In the woods, near the beautiful waterfall, where the river forces its way through a narrow cleft in the gneissose rocks, I lost my way, and was attacked by myriads of mosquitosthe only occasion, owing to the unusual coolness of the season, on which I was annoyed by these enemies, so much dreaded here by the lovers of angling.

When standing on the wharf at Three Rivers, I conversed with the proprietor of a large estate in the Eastern townships, who complained to me that while crowds were passing up the river every week to remote districts, and sometimes returning disappointed, and even occasionally re-crossing the Atlantic, he and other farmers were unable to get hands. While he was speaking, a large steamer, with several hundred Scotch emigrants from Ayrshire, came alongside the wharf. They were only to tarry there one hour to take in wood for the engines. My companion 
went on board, eagerly endeavouring to bribe some of the new-comers to settle on his farm, but all in vain. They said they had cousins and friends in "Upper Canada," and were all resolved to go there. I could not help sympathizing with him in his disappointment, and the more so, as I had seen at Toronto large bands of Irish and Welsh peasants in a state of destitution for want of work; and in spite of the liberality of the citizens, several gangs of them, while we were there, committed robberies in the neighbourhood. It appears that during the late troubles in Canada the tide of immigration was almost entirely stopped for several years; now it is setting in more strongly than ever: but as they come from all parts of the British Isles, it is scarcely possible, unless the whole system of colonising were under government regulation, and conducted on arbitrary principles, to adjust the supply of labour to the various and ever-fluctuating local demands.

When passing in a carriage over the rich alluvial grounds on the left bank of the St. Lawrence, I expostulated with some of the English proprietors on the intolerable condition of the muddy roads. I reminded them that all this part of Canada was a cleared and cultivated country, when half the United States was still a wilderness. They replied, that the French farmers, to whom most of the land belonged, refused to pay taxes for bettering the roads, contending that it was preferable to spend more time on the way, and to wear out their horses and vehicles somewhat faster, than to pay down money to a taxgatherer.

The anecdotes told us by the British settlers, of 
the superstitious horror of the old Canadians at the new inventions and innovations of the Anglo-Americans, were very amusing. The river craft of the Canadian "voyageurs" was so unrivalled in its way that we may pardon them for beholding the first steamers with jealousy. One of them is said to have exclaimed, as he saw them ascending the St. Lawrence, "Mais croyez-vous que le bon Dieu permettra tout cela?" During this tour I often thought of the old story of the American, who said that "if the United States ever got possession of Canada, they would soon improve the French off the face of the earth." The French party speak of the late Lord Sydenham as if they really believed him capable of conceiving and executing such a project. On the other hand, not a few of the English settlers, while they praised his zeal and habits of business, and devotedness to the interests of Canada, took pains to persuade me that if his measures were enlightened, his means of carrying them through the legislature were equally unscrupulous. One of his admirers, deeply imbued with the spirit of his policy, is said to have declared, "We shall never make anything of Canada until we anglicize and protestantize it;" to which a French seigneur rejoined with bitterness, "Had you not better finish Ireland first?"

Some of the American travellers whom we met here were extremely entertained with the military display of the large army now quartered in this province, the reviews, the bands of music, the trains of baggage-wagons, which they occasionally met on the roads, the barracks of infantry and cavalry, the new fortifications of Kingston, and the old ones of Quebec. 
All this warlike parade, after a sojourn of nine months in the United States, appeared almost as great a novelty to us as to them; but the resemblance of the colony to a garrison afforded me no pleasure. It was a perpetual remembrance of the late troubles, and of that former mismanagement of which a civil war, however unjustifiable, affords ample proof. It reminded me also of the difficulties with which the wisest and bestintentioned government will have to contend, whose task it is to fuse into one harmonious whole two populations so dissimilar in origin and language as the French and British, and all whose ideas on social, political, and religious subjects, are so discordant. It recalled, moreover, to mind the unwarrantable conduct of those turbulent borderers, the American "sympathizers," who poured in by thousands to aid the insurgents, and whose intervention alone rendered the rebellion formidable for a time.

Great indignation was expressed to me by many Canadians, that these citizens should have been allowed with impunity, by the governor of New York, to take cannon out of a public arsenal, and invade a friendly territory in time of peace.

"Non cogente quidem sed nec prohibente tribuno."

Some New Yorkers, on the other hand, while they freely condemned the sympathizers, and said they had rejoiced in their defeat, defended their governor, saying it was impossible for him to have foreseen and provided against so sudden a movement along so extensive a frontier; that neither he nor the federal government had troops enough at their command to act as a sufficient police; and $10 *$ 
that it was too much to expect of them to maintain, permanently, a large standing army for the sake of being prepared for such rare emergencies.

That the whole of the British force now kept up in this colony is absolutely needed, I venture not to doubt; but they who refuse to hope for its speedy reduction, appear to me to libel by anticipation our future colonial policy. I listened with no small impatience to the wishes expressed by some residents, that this full war establishment should be permanent, and to their discussions on the desirableness of new fortifications, to be executed at great cost by England, and of fleets of war-steamers to be built on the lakes, in order that they might at all times be ready for an outbreak with the United States.

The population of the British possessions in America, in 1842, amounted in round numbers to one million and a half.

$\begin{array}{llll}\text { Lower Canada } & - & - & \mathbf{6 9 0 , 0 0 0} \\ \text { Upper Canada } & - & - & \mathbf{5 2 6 , 0 0 0} \\ \text { New Brunswick } & - & - & \mathbf{1 5 6 , 0 0 0} \\ \text { Nova Scotia } & - & - & \mathbf{1 8 0 , 0 0 0} \\ & & & 1,552,000\end{array}$

The annual growth of the population of the United States, with which their wealth and territory keep pace, exceeds at present 700,000 souls, so that every two years' increase is about equal to the number of all the present inhabitants of British America. The mere contemplation of these figures 
would seem to me enough to convince a reasonable man, that Canada must owe her security from external aggression, not to local armaments and provincial demonstrations, but to the resources of the whole British empire. A surplus revenue at home, or the remission of taxes which press heavily on industry and commerce, and economy in administering our colonial affairs in times of peace, are the true means of fortifying the Canadian frontier.

The legislature of Canada have lately voted a sum of money for a geological survey of the province, which has been placed under the direction of $\mathrm{Mr}$. Logan, from whose labours we may soon expect an accurate map, with a description of the rocks and their organic remains, and a comparison of them with the equivalent formations in the United States. My own observations were confined to the valley of the St. Lawrence and its environs, where I was struck with the remarkable analogy between the structure of this part of North America and those portions of Scandinavia which I visited in 1834 and 1836. I seemed to have got back to Norway and Sweden, where, as in Canada, gneiss and mica schist, and occasionally granite, prevail over wide areas, while the fossiliferous rocks belong either to the most ancient or the very newest strata, to the Silurian rocks, or to deposits so modern as to contain exclusively shells of recent species. In both countries, we pass over enormous spaces, without beholding any formations of an intermediate age. In both, large erratics, or far-transported fragments of rock, have been carried from north to south, while the surfaces of solid rocks, covered at 
various heights by gravel, sand, and clay, have been smoothed and furrowed.

There are large parts of Scandinavia, where the Silurian strata have not been invaded by trappean rocks, whether felspathic or basaltic. There are others, where these igneous materials have intruded themselves, both in the form of dykes and overlying masses, as in Sweden, at Kinnekulle near Lake Wener, and in Norway near Christiania. The same geological condition of things recurs in Canada, the mountain of Montreal affording a good example of slightly disturbed Silurian limestone full of shells and corals, with a capping of basalt or greenstone about eighty feet thick, which terminates abruptly towards the river, giving a picturesque outline to the hill. (See fig. 13., p. 117.) Numerous dykes or veins of trap, both felspathic and augitic, are seen penetrating the limestone, and some of them sending ramifications through it. One of the felspathic dykes (d, fig. 13), consisting of claystone-porphyry, was well exposed to view by new excavations near M.Gill's College, at the time of my visit.

The limestone of this mountain, and of other districts in the valley of the St. Lawrence and the adjoining country, agrees in its fossils with the Trenton limestone of New York. (No. 15 of map Pl. II.) The same is seen at the Falls of Montmorenci, where it rests on the ancient sandstone (No. 15), called the Potsdam sandstone, the lowest of more than twenty fossiliferous formations older than the coal, which are recognized in the classification of the New York surveyors. The upper part of this sandstone, at the falls above mentioned, is re- 
markable for containing boulders of enormous size, the largest I ever remember to have seen in any ancient stratified rock. I measured some of them which were eight feet long, but they may have been derived originally from the destruction of rocks in the immediate neighbourhood, as they consist of the same gneiss as that on which they rest, and therefore cannot be said, like certain modern erratics in Canada, to point to glacial action, or to imply that large blocks were transported by icebergs at a very remote period.

The strata of black slate, commonly called greywacke in Canada, which appear in a highly inclined position immediately below the Falls of Montmorenci, have, no doubt, been correctly referred, by Professor Emmons, to the slate of the Hudson river series. (No. 14. of map Pl. II.) In consequence of a derangement or fault in the strata, they appear, on a cursory view, to belong to an older formation than the less disturbed limestone and sandstone before mentioned. This fault is so extensive, that it has misled many of the earlier explorers of the valley of the St. Lawrence, who naturally concluded that the inclined greywacke was more ancient than the horizontal limestone of the same district, whereas it occupies in fact a higher place in the series.

The termination downwards of the most ancient fossiliferous rocks of Canada in a stratified quartzose sandstone with few fossils affords another point of analogy between the geology of Scandinavia and North America. An additional one is supplied by the unconformable superposition in both hemispheres of the inferior sandstone to gneiss. I saw a junc- 
tion of this kind at Kinnekulle in Sweden, and in the U. S. at Little Falls on the Mohawk; and afterwards on the western borders of Lake Champlain in the U. S. At Little Falls, however, the ancient strata, which rest upon gneiss, do not belong precisely to the same part of this lower member of the Silurian series as those at Montmorenci, but to the beds next above the Potsdam; namely, those called the calciferous sandrock by the New York surveyors. This circumstance should serve as a warning against the hasty assumption that in any of these sections we have positively arrived at the lowest stratum containing organic remains in the crust of the earth, or have discovered the relics of the first living beings which were imbedded in sediment.

When reasoning on this subject, we must not forget that the oldest formations are those which must have suffered the greatest loss by aqueous denudation, and which have been most extensively altered by plutonic action. We must also remember how small a part of the earth's crust is accessible to human observation, three-fourths of the surface of the globe being submerged beneath the ocean, and a fraction only of the remaining portion having been as yet carefully investigated by geologists. Nor must we overlook the large spaces occupied by formations newer than the Silurian, which may conceal from our view fossiliferous strata older than any yet brought to light.

As it is still a favourite theory of many geologists, that the granite and other formations, both stratified and unstratified, which I have called hypogene, were produced in far greater abundance before the origin 
of the oldest strata at present known to contain fossils than at any subsequent period; and as some are disposed to consider their conclusions on this head much strengthened by the fact that, in North America, as in Europe, there are certain points where granite, mica schist, and gneiss, can be shown to be of prior date to any of the fossiliferous rocks hitherto detected; I shall briefly refer to the leading arguments against this doctrine, which $I$ have advanced both in my "Principles" and "Elements of Geology."

The crystalline formations, such as granite and gneiss, were termed primitive and primary by some of the earlier observers, because in each district they are the lowest in geological position. It is now understood, in regard to granite, syenite, and the unstratified class, that they are of various ages, often newer than-fossiliferous strata, and that it by no means follows that they were first in the order of time, because they are inferior in position. Paradoxical as the first statement of this proposition appears, it is now acknowledged, that the superstructure is often older than the foundation on which it rests, the latter having been forced up subsequently from below either in a solid form, or, more frequently, like lava in a volcano. It is also now admitted, in direct contradiction to all preconceived opinions, that many stratified hypogene formations, the gneiss, mica schist, talcose schist, and saccharine marble of the Alps, Appenines, and other districts, have assumed their crystalline texture after the origin of many of the fossiliferous strata, even in some cases long after 
the deposition of those which repose directly upon them.

Nevertheless, if we confine the term primary to all rocks which we can prove to be of older date than strata in which organic remains have yet been discovered, we may affirm that the gneiss of Kinnekulle in Sweden before alluded to, or of the Falls of Montmorenci, and many of the unstratified or Plutonic rocks of the Adirondack Mountains, west of Lake Champlain, are truly primary. We may also extend the same appellation, without much liability of error, to all the crystalline rocks found for a considerable space on every side of the points where the lowest strata charged with fossils are incumbent upon the non-fossiliferous formations. But the farther we go from such points of departure, the more unsafe does our generalization become; and the American geologists have already found reason to retract their first conclusion, that the gneissose, micaceous, and talcose schists, of the Taconic range (see above, p. $\mathbf{2 4 5}, \mathrm{Vol}$. I.), are referable to a primary series.

The posteriority of age of many masses of granite and other Plutonic rocks is more easily proved than the modern origin of the stratified hypogene formations, because the former produce alterations of moderate extent, at the point of contact, or send veins into the newer fossiliferous strata. But where these strata have been altered on a great scale in texture, by heat and other subterranean causes, the evidence of transmutation is difficult to detect in proportion to the intensity of the metamorphic action. The study of the Alps and Appenines has shown that it is characteristic of such action to annihilate all signs of the 
date of its development, by the obliteration throughout entire mountain masses of all traces of organic structure. We are therefore entitled, on every principle of sound reasoning, to suspect, that for one case where we can positively establish the secondary origin of any set of crystalline strata, there are many others where the proofs of their modern origin have been destroyed.

A geologist whose observations had been confined to Switzerland might imagine that the coal measures were the most ancient of the fossiliferous series. When he extended his investigations to Scotland, he might modify his views so far as to suppose that the Old Red sandstone marked the beginning of the rocks charged with organic remains. He might, indeed, after a search of many years, admit that here and there some few and faint traces of fossils had been found, in still older slates, in Scotland; but he might naturally conclude that all pre-existing fossiliferous formations must be very insignificant, since no pebbles containing organic remains have yet been detected in the conglomerates of the Old Red sandstone. Great would be the surprise of such a theorist, when he learnt that in other parts of Europe, and still more remarkably in North America, a great succession of antecedent sets of strata had been discovered, capable, according to some of the ablest paleontologists, of constituting no less than three independent groups, which are each of them as important as the "Old Red" or Devonian system, and as distinguishable from each other by their organic remains. Yet it would be consistent with methods of generalizing not uncommon on such subjects, if he VOL. II. 
still took for granted that in the lowest of these "Transition" or Silurian rocks, he had at length arrived at the much-wished-for termination of the fossiliferous series, and that nature had begun her work precisely at the point where his retrospect happened then to terminate.

It may be useful to inquire, whence arises this strong tendency to believe that the present limits of human knowledge in geological science exactly embrace that period of past time in which organic beings have flourished on the earth. If it be a very common delusion, there must be some cause for its popularity. Its source is, I believe, twofold; first, it is almost unavoidable that we should under-rate the magnitude of the subterranean changes now in progress at great depths in the earth's crust; and, secondly, that we should equally exaggerate the amount of those which took place far below the surface at former eras, especially those most remote from our times.

In regard to the first of these sources of error, we have of late years grown familiar with the proofs of great subsidence and upheaval of land in modern times, without sufficiently reflecting on the enormous alterations in the condition, and probably the structure, of the subjacent parts of the earth's crust, which are implied by these movements. The connection of such rising and sinking of the solid parts of the globe with volcanic action can be demonstrated in many places, and fairly inferred in others, where the action of subterranean heat, owing to its great depth, is latent. I have endeavoured elsewhere to explain the grounds which we have for inferring that crystal- 
ine formations have been elaborated at many successive periods, both secondary, tertiary, and still more modern. We need go no farther, indeed, than the valley of the St. Lawrence, now under consideration, to find wide areas covered with marine shells of recent species, at the height of 500 feet above the sea, and where all the rocks can be shown, both to have sunk and to have been again uplifted bodily, for a height and depth of many hundred feet, since the deposition of these shells.

But however firmly we may be convinced that subterranean causes, connected with the development of internal heat, have operated with great, and perhaps nearly uniform intensity, at each successive geological period of equal duration, we must still be prepared to find that by far the largest portions of the visible hypogene rocks are of high relative antiquity to the fossiliferous deposits. This must happen, if we are correct in assuming that the crystalline rocks, whether stratified or unstratified, have been formed originally at considerable depths in the crust of the earth. For in that case, a long period of time must have elapsed after their origin before they can have been brought up within the sphere of human observation. There must have been great upheaval and denudation to cause them to emerge, even in a single district; but it must require a series of geological epochs before those formed at a given era of the past can have become generally exposed at the surface. A repetition of one series of elevatory movements after another must have taken place in different areas, accompanied by denudation; and while such forces are acting, the deposition of new strata is going on. 
and the pre-existing crystalline rocks are becoming relatively more and more ancient.

What was before said of the succession of ages required to raise deep-sea formations extensively to the surface (see p. 47) is equally applicable to rocks of deep subterranean origin. Hence it follows that the high relative antiquity of the visible crystalline rocks affords no better a presumption in favour of a period when nothing but granite and gneiss were formed, than the pelagic character of the visible Silurian strata and the absence of contemporaneous littoral deposits, imply the universality of the ancient ocean. 


\section{CHAPTER XXII.}

Glacial Furrows in the Valley of the St. Lawrence.-Action of packed Ice in the Canadian Rivers.-Boulder Formation with and without Shells.-Gannanoqui.-Mountain of Montreal.- Recent Shells in Drift more than 500 Feet above the Sea.Lake St. Peter.-Falls of Maskinongé.-Deposit of Shells at Beauport near Quebec.-Agreement with Swedish Fossils.Shells in Boulder Formation of Lake Champlain.-Burlington, Vermont.-Fossils of Drift imply a colder Climate.Scenery of Lake Champlain.-Organic Remains of lowest Silurian Sandstone.-Lingula.-Vermont Mountains.-Inns and Boarding Houses.-Return to Boston.

I HAD frequent opportunities in the valley of the St. Lawrence, especially at Kingston, and in the country between that city and Gannanoqui, of examining the recently bared surface of the fundamental rocks, consisting of, first, granite ; 2dly, quartzose (or Potsdam) sandstone; 3dly, lower Silurian (or Trenton) limestone. Wherever the drift or superficial clay and gravel have been removed, the surfaces of these rocks are worn, smoothed, and furrowed, the furrows being least clearly defined on the sandstone.

The direction of all the straight and parallel grooves was nearly N. E. and S. W., differing uniformly in their general course from those traced by Professor Hitchcock and Mr. Percival through New England, where they run usually from N. N. W. to S. S. E. It is worthy of notice, that in both regions the erratic blocks and boulders have been transported southwards, along the same lines as are marked out by 
the direction of the furrows. There is obviously, therefore, a connection between these two distinct classes of phenomena; and I know of no theory that can account for both of them, with any plausibility, except that already alluded to in the last chapter, viz., the agency of large islands of floating ice, which, by their buoyancy and enormous weight, supply the carrying power and pressure required to scratch, polish, and groove the solid floor of the ocean, and to convey stones of all sizes, firmly fixed and frozen into the ice, to great distances.

As large masses of ice are annually accumulated in the rivers of Lower Canada, and when they break up in spring are often the means of conveying from place to place, huge fragments of rock, I hoped to discover indications, not only of the polishing, but also of the grooving of the surface, at those points where the packed ice is forced every year over the bottoms of the Canadian rivers. Accordingly, at Quebec, I went with Colonel Codrington, and searched carefully below the city in the channel of the St. Lawrence, at low water near the shore, for the signs of glacial action, at the precise point where the chief pressure and friction of packed ice are exerted every year. But the edges of the worn greywacke slates, in the channel there, are scarcely any of them hard enough to receive or retain such markings, and if they were so, the weight of the ice would probably be insufficient. At the bridge above the Falls, at Montmorenci, over which a large quantity of ice passes every year, the gneiss is polished, and kept perfectly free from lichens, but not more so than rocks similarly situated at waterfalls in Scotland. In none 
of these places were any long straight grooves observable, and I feel persuaded that any degree of freedom of motion in the rocky fragments forced along by small pieces of ice, or by a flood of water, would be quite incompatible with the mechanical effects exhibited in what are called glacial furrows.

I have stated that, between Kingston and Quebec, the quartzose sandstone retains the grooving much less distinctly than the limestone or granite. The largest area over which I observed the furrows to preserve a perfect parallelism, was a floor of limestone forty yards wide, from which clay had recently been removed. It was situated about six miles west of Gannanoqui. I saw the surfaces of smoothed granite on the Rideau Canal, six miles north of Kingston, swelling into those flattened dome-shaped forms called "roches moutonnées," so common in Sweden, and near the glaciers in Switzerland.

Although in this part of Canada the boulders are usually uppermost, yet at some points, near Gannanoqui, and elsewhere, they have been found, in sinking wells, to lie thirty feet deep in the clay and sand.

The St. Lawrence, in its course from Lake Ontario to Montreal, a distance of about 160 miles in a direct line, has a wide extent of low ground on both sides of it. The river falls in that distance 214 feet, descending by a succession of rapids, between which are lake-like expansions. At the rapids, the Transition limestone, or sandstone, or the intrusive trap, or subjacent gneiss, are exposed, but the valley is for the most part occupied by the boulder formation, the thickness of which, at the Belouse rapid, and at 
Cornwall, varies from twenty to forty feet. At Coteau du Lac, "the Cascades," and St. Ignatius, it constitutes a broad terrace, 80 to $\mathbf{1 0 0}$ feet above the St. Lawrence, and the small streams which drain the terrace have cut deep gulleys or valleys through the clay.

This drift, or deposit of clay, sand, and gravel, is more usually stratified than that associated with large boulders in Scotland. It is generally destitute of organic remains, but in a few places contains them in abundance. In order to show the identity of the fossiliferous and non-fossiliferous portions of this formation, it will be necessary to enter into some details, which may not be without interest to the geologist who considers in how much obscurity all phenomena bearing on the glacial period is still involved.

Travelling from the south-west, I found no shells in the drift till I reached Montreal, which stands at the base of a mountain rising abruptly from a broad plain where the valleys of the St. Lawrence and the Ottawa meet. This mountain, which is $\mathbf{7 4 0}$ feet high above the St. Lawrence, terminates in two summits, one considerably higher than the other, and capped, as before stated, with a mass of greenstone about eighty feet thick. The subjacent beds of Silurian limestone are traversed by dykes and veins of trap. At the base of the hill, on its eastern side, in the suburbs of Montreal, we find clay and sand ( $d, e$, fig. 13) above 100 feet deep, in which marine shells occur. This deposit forms a terrace which ends abruptly in the steep bank (e) facing the river-plain, and running parallel to it for three or four miles. 
It varies in height from 50 to 150 feet, and at its base is a low flat of more modern gravel $(f)$, rising from ten to twenty feet above the St. Lawrence. In certain places, as at the Côte St. Pierre, on the road from Montreal to Lachine, the surface of the terrace slopes from $e$ to $d$, or towards the mountain. A good section of this modern deposit was to be seen at the Tanneries, a village in the parish of St. Henri in the

Fig. 13.

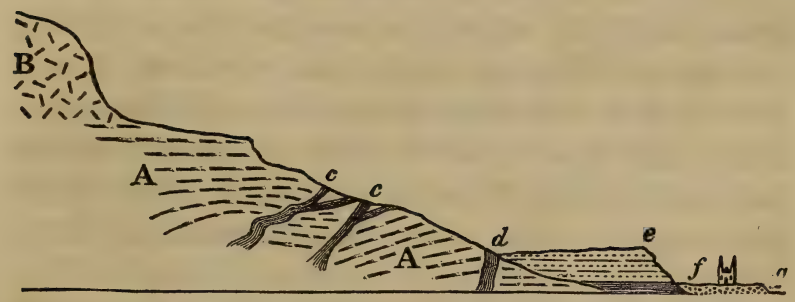

Section of Montreal mountain, with shelly drift at its base.
A. Silurian limestone.
B. Trap or greenstone.
c. Dykes of basaltic trap.
$d$. Dyke of felspathic trap, or claystone-porphyry.
d. $e$. Terrace of drift with shells.
$f$. Gravel, on which part of Montreal stands.
g. River St. Lawrence.

suburbs of Montreal, at the time of my visit (June, 1842). Excavations had recently been made for a new road, exposing horizontal beds of loam and marly clay, in one of which, at the height of about sixty feet above the St. Lawrence, I observed great numbers of the Mytilus edulis, or our common European mussel, the shells retaining both valves and their purple colour. In the same beds were specimens of Tellina gronlandica, and a few of Saxicava 
rugosa. In the midst of the shells, I found a single isolated boulder of gneiss, six inches in diameter. The Mytilus, although so abundant in this bed, is by no means of common occurrence in the drift of Lower Canada. The colour of the layers containing the Mytilus reminded me of those purple marls which I had seen in the boulder formation of Sweden, produced by the decomposition of countless numbers of these same shells.*

At the Côte St. Pierre, near the house of Mr. Brodie, forty feet above the section in the road last mentioned, and about ninety feet above the river, gravelly beds appeared, in which the Tellina grænlandica and Mya arenaria were abundant, retaining both valves; they were also accompanied by Saxicava rugosa. The shelf $(d, e)$ containing these remains is intersected here and there by deep narrow gullies, one of which terminates at the Tanneries. In the channels of the small streams draining these gullies I found fossil shells, washed out of the clay and sand, among which were a new species of Astarte (A. Laurentiana), Saxicava rugosa, and Tellina grænlandica, yet nowhere could I see a single shell in situ. At some points, the upper beds of sand and gravel, at the same level as the shelly beds with Mytilus, before alluded to, become very coarse, and contain boulders of gneiss and syenite three feet in diameter, showing the inseparable connection between the fossils and the ordinary boulder formation of Canada.

As I could find no organic remains at any points higher than the terrace $d, e, f i g .13$, or none that were 
elevated 200 feet above the river, I might have gone away with the notion that the fossiliferous drift was confined to a comparatively low level, if Mr. Logan had not informed me the year before that $\mathrm{Mr}$. M`Cord had been fortunate enough to meet with a small patch of gravel full of sea-shells at the height of more that $\mathbf{5 0 0}$ feet in the hollow between the two eminences which form the Montreal mountain. I was conducted by Dr. Holmes to this place, called the Côte de Neige, and found there a bed of gravel six feet thick, containing numerous valves of recent species, Saxicava rugosa. and Tellina gronlandica. The deposit was covered by an unstratified mass of boulders and gravel twelve feet thick, which would have entirely concealed the shelly beds, had not the gravel been lately dug for road-making.

Mr. M‘Cord estimated, from barometrical measurements, the height of these shells above the St. Lawrence, at Montreal, at 429 feet, which would give them an elevation above the sea of about 450 feet; but the same series of barometrical observations gave only 668 feet for the summit of Montreal mountain above the river, whereas Capt. Bayfield determined, by the mean of three trigonometrical measurements, the true height to be 760 feet, or 92 feet more. I am inclined, therefore, to believe that the shells are 520 feet above the river, or $\mathbf{5 4 0}$ feet above the sea, which gives an elevation of 306 feet above Lake Ontario, and places them nearly on a level with Lake Erie, which is $\mathbf{5 6 5}$ feet above the sea. Even if we adopt the lower estimate of $\mathrm{Mr}$. M`Cord, and suppose the shells to be only 450 feet above the sea, they would be within $\mathbf{5 5}$ feet of the summit of the Falls of Nıa- 
gara, and more than 200 feet above Ontario, between which lake and the mountain of Montreal there is an open and uninterrupted valley.

After this discovery of marine shells of living species, at so great an elevation in the drift of Canada, we must either conclude that the boulder formation of the Niagara district was deposited in the same sea, or abandon all idea of any approach to uniformity in the last series of upward movements, which raised the great lake district to its present height.

Between Montreal and Quebec, a distance of about 140 miles, in a straight line, I found the older rocks covered with a stratified drift similar to that already described, the lower beds usually consisting of laminated clay, and the upper of sand ; but this arrangement is not constant. Boulders are for the most part sparingly interspersed, and often only seen on the surface. As I know that Capt. Bayfield had met with marine shells in abundance, in the drift at several points between Quebec and Montreal, I inquired everywhere for fossils in the intervening country, but neither at Sorel, nor between Berthier and Maskinongé, nor on the shores of Lake St. Peter, could I see or hear of any.

At Lake St. Peter, the St. Lawrence expands into a lake, bounded by a low alluvial flat, which is sometimes several miles broad. This flat is in its turn bounded by a steep bank of sandy drift forty feet high, in which I could find no shells. Ascending it to a higher level, I went for nine miles over a sloping terrace of drift to the base of the mountains of gneiss, where the Falls of Maskinongé are situ- 
ated. On the way, I examined the clay and yellow sand of St. Ursule, and other places, but was unable to detect a single shell. At the falls, at a height of more than 300 feet above the St. Lawrence, the gneiss makes its appearance in rounded domes (roches moutonnées). Higher up, or more than $\mathbf{4 0 0}$ feet above the St. Lawrence, the same gneiss is again covered deeply with stratified yellow sand, similar to that of the lower grounds.

Although, during my short stay, I was equally unsuccessful in detecting any marine shells at Three Rivers, they have been met with in the neighbourhood, and at Port Neuf, and on the banks of the Jacques Cartier river, twelve miles above its junction with the St. Lawrence, about thirty miles above Quebec. My friend Col. Codrington observed there a fine section of drift, laid open by a landslip in May, 1842. At the top of the cliff was sand about thirty feet thick, and below blue clay, with shells of Tellina calcarea, $T$. gronlandica, and Astarte Laurentiana.

I shall next describe the drift with shells in the immediate neighbourhood of Quebec, respecting which my curiosity had been excited as early as the winter of 1835, when Capt. Bayfield, then engaged in a trigonometrical survey of Canada, sent me a collection of marine fossil shells. In his letter, he described them as occurring in very modern strata, bordering the St. Lawrence, at a viliage called Beauport. When they arrived in London, Dr. Beck of Copenhagen, an eminent conchologist, happened to be with me; and great was our surprise, on opening the box, to find that nearly all the shells agreed specifically with fossils which, in the summer of the preceding 
years, I had obtained at Uddevalla in Sweden, and figured in my paper "On the Rise of Land," \&c., in the Phil. Trans. for 1835. Among the species most abundant in these remote regions (Scandinavia and Canada), were Saxicava rugosa, Mya truncata, $M$. arenaria, Tellina calcarea, T. grænlandica, Natica clausa, and Balanus Uddevallensis. All of them are species now living in the northern seas; and whereas I had found them fossil in latitudes $58^{\circ}$ and $60^{\circ} \mathrm{N}$. in Sweden, Capt. Bayfield sent them to me from part of Canada, situated in latitude $47^{\circ} \mathrm{deg}$. N. In both hemispheres, they are most abundant at moderate elevations above the sea, not exceeding usually 200 or 300 feet, but occasionally, in Norway, they attain, as at Montreal, much higher levels. As some of them belonged to species now living in the Greenland and other seas in high latitudes, Dr. Beck and I immediately concluded that this fossil fauna, having an almost arctic character, must formerly have had a wider range than the same assemblage of species at present.

Captain Bayfield had called my attention in his letter to the fact, that boulders accompanied the shells in such a manner as to imply, that they had been dropped from melting icebergs to the bottom of a sea, in which the mollusca lived and died. He also furnished me with evidence, that the testacea now inhabiting the Gulf of St. Lawrence, differed widely as a whole from the fossil fauna of Beauport.*

* See my paper on this subject, Geological Trans. vol. vi., Second Series. p. 135, read 1839. 
The village of Beauport is about a quarter of a mile distant from the St. Lawrence, on its left bank, and about three miles below Quebec. Near it, a small streamlet flows in a narrow ravine, about 110 feet deep, partly excavated in the drift, which, like that of St. David's before described (p. 95), had filled a more ancient hollow in the Silurian strata. By examining the cliff immediately below Mr. Ryland's house, and again a few hundred yards to the west, where lower beds were laid open by the river, and then ascending to the higher grounds northwards and towards St. Michel, I obtained the annexed section, the different parts of which I shall now describe.

Fig. 14.

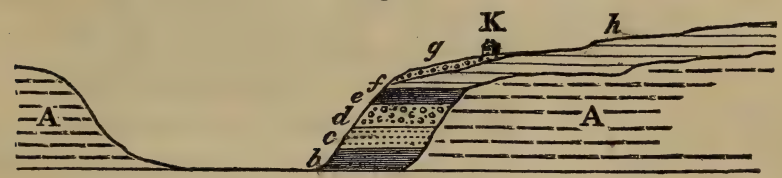

Position of shelly drift in the ravine at Beauport, near Quebec.

A. Horizontal Lower Silurian strata.

b. Laminated clay.

c. Yellow sand.

d. Drift with boulders.

e. Mya, Terebratula, \&c.

f. Mass of Saxicava rugosa.

g. Gravel with boulders.

$h$. Clay and sand of higher grounds, with Saxicava, \&c.

K. Mr. Ryland's house.

The lowest mass of drift (b, fig. 14), having a thickness of twenty-five feet, consists of fine, laminated, stiff blue clay, without fossils, similar to that containing shells on the Jacques Cartier, before mentioned. Next above, the beds $c$ are composed of incoherent yellow sand, in regular layers, about twenty-five feet thick, also without shells. In the next mass, $d$, of loam and blue clay, having also a 
thickness of twenty-five feet, large boulders of dark syenite are frequent. I found no contemporaneous fossils, but fragments of Encrinus and Trilobite, derived from the older formations. Above this, in $e$, the fossils commenced. In the lowest five or six feet, they are rare, but become more abundant above. They are embedded in layers of sand and loam with pebbles. The Tellina calcarea is most common, after which may be mentioned Mya truncata, Terebratula psittacea, with both valves united; Mytilus edulis, Scalaria borealis, S. grænlandica, and several others.

To these succeeds a remarkably compact mass of shells, $f$, twelve feet thick, rudely stratified, consisting almost entirely of the Saxicava rugosa, most of them having the valves united. They are disposed in layers in every position, oftentimes end upwards, and are intermixed with a slight quantity of earthy matter and pebbles, some of the latter being eight inches in diameter. Most of the shells are bleached white, but there is one layer, an inch thick, in which they are stained of a ferruginous colour, as in the English Crag. The individuals of the Saxicava are smaller in their average size than those of the same species in the great bed of Uddevalla, in Sweden. With the Saxicava is associated Balanus miser, and more rarely Natica clausa and Mytilus edulis.

The topmost bed, $g$, in this vertical section, is two or three feet thick, and consists of sand, gravel, and boulders of granite, distinct from the boulders in $d$; but the mass $g$ appeared to me to be superficial, and not to belong to the shelly drift. The bed of Saxicava, $f$, is about $\mathbf{1 5 0}$ feet above the level of the St. Lawrence, but is by no means the newest part of the 
drift of this region, for I found the ground immediately above, or north of $\mathrm{K}$, to consist of a sloping terrace, in which are horizontal strata of clay and yellow sand, as at $h$, containing Saxicava rugosa, Tellina gronlandica, and other marine shells. Some of these fossiliferous beds were within a quarter of a mile of Mr. Ryland's house, $\mathrm{K}$, and about 200 feet above the St. Lawrence ; but I observed other similar beds without shells several miles inland, in a north-westerly direction, from 300 to 400 feet above the sea.

The following is a list of twenty-three species of fossils which I procured at Beauport :-

Tritonium anglicanum. Syn. Buccinum undatum, var.?

T. fornicatum. Syn. Fusus carinatus.

Trichotropis borealis.

Natica clausa. N. septentrionalis, Beck.

5. Velutina.

Scalaria grœnlandica.

S. borealis.

Littorina palliata, Say.

Mya truncata.

10. M. arenaria.

Saxicava rugosa.

Tellina grœnlandica.

T. calcarea. Agrees with recent species from Boston.

Astarte Laurentiana. New species: see description in note.*

* Fig. 15. Astarte Laurentiana.

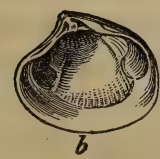

a. Outside.

c. Inside of left valve.
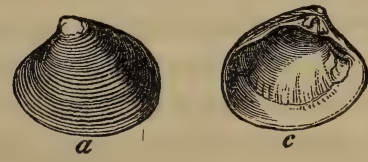

b. Inside of right valve. 
15. Cardium grœnlandicum.

C. islandicum.

Nucula. Agrees with recent species found by Capt. Bayfield in the St. Lawrence.

Mytilus edulis.

Pecten islandicus.

20. Terebratula psittacea.

Balanus miser.

B. Uddevallensis. Syn. B. scoticus. Found recently in the German Ocean, off Scarborough.

Echinus granulatus, Say.

At the falls of Montmorenci, the most northeastern place which I visited in this neighbourhood, I saw on the right bank of the river, above the falls, and close to the bridge, a bed of gravel and sand, containing large boulders of gravel and syenite, some of them three feet in diameter. In this coarse gravel the Saxicava rugosa and Tellina gronlandica occurred. The whole mass rested on Lower Silurian limestone.

I did not examine the valley of the Ottawa River (see map); but I may mention that Mr. Logan obtained near Bytown concretions of clay similar to

This must be regarded as an Astarte, although somewhat different from the usual form; it is comparatively thin, it is more longitudinal, it is deeper or more gibbous; the posterior lateral tooth in one, and the anterior lateral tooth in the other valve, are more than usually prominent. The shell has all the usual characters of the Astarte ; among others, the small second vascular impression placed above the anterior adductor muscle. The following are its characters :-

A. testâ subovali, sublongitudinali, tenuiusculâ, gibbosulâ, extûs concentricè confertim sulcatâ; dente laterali utriusque valvæ prominentiori. 
those called fairy stones, which occur without fossils in the clay at Albany, New York, and at Burlington, Vermont, and in Massachusetts, as described by Professor Hitchcock. In the centre of one of these nodules was the entire skeleton of a fossil fish, allied to, if not identical with, that named Mallotus villosus by Professor Agassiz, which now lives in the Greenland seas, and is also found fossil in Greenland.

The only remaining district seen by me where shells have been discovered in the boulder formation, is on the borders of Lake Champlain, about eighty miles south of Montreal. The basin of this lake may be considered as a southern branch of the valley of the St. Lawrence, and the locality is important, as being the most southern latitude $\left(\begin{array}{ll}44^{\circ} & 2^{\prime} \\ \end{array}\right.$ which this assemblage of arctic fossils has been traced. Professor Emmons has given an account of the spot where the shells occur, south of Port Kent, in the county of Essex, State of New York, at a point where a small brook enters on the western side of the lake. In this place I observed, at the bottom of the section, first, clay, thirty feet thick, with boulders of gneiss, granite, limestone, and quartzose (Potsdam) sandstone, some rounded blocks of the latter being nine feet in diameter; secondly, loam with shells, six feet thick; thirdly, sand, twenty feet thick. Although the shells in the second bed, or the loam, were very numerous, I could only detect four species, namely, Mytilus edulis, Saxicava rugosa, Tellina gronlandica, and Balanus miser.

Travelling inland from this spot to Keeseville, I found the boulder formation of great depth, covering the older rocks, and the ascent to an elevation of 
about 500 feet is by a succession of terraces, composed chiefly of beds of sand. I consider the whole of these strata to be upper members of the same deposit, doubtless all marine, although no shells have yet been met with at a greater height than forty feet above the lake.

At Burlington, in Vermont, on the opposite or east side of Lake Champlain, the drift consists chiefly of clay, laminated and micaceous, or unlaminated and without mica. In this clay, argillaceous concretions of curious forms occur. In some places beds of brick earth, sand, and gravel, are associated, pebbles and boulders being scattered sparingly through the loam. Professor Benedict pointed out to me several spots where this loam behind the town, at the height of thirty and forty feet above the lake, contains shells of the Tellina gronlandica, without any other species. In like manner, I afterwards observed this Tellina in a recent state, on the shores of the Bay of Fundy, in Nova Scotia, strewed for miles along the beach unmixed with other species. At the Falls of the Winouski or Onion River, near Burlington, the boulder clay attains a thickness of 200 feet. Although in great part marly and calcarcous, it is barren of shells. There has evidently been great denudation of the drift around Lake Champlain, and I conceive that most of the large boulders of granite, syenite, and sandstone, which now rest upon the surface, may once have been dispersed through the mass. Nothing, however, is clearer than that here, as well as in the valley of the St. Lawrence, between Kingston and Quebec, the marine shells of recent species are referable to the 
same geological period as that to which the boulders belong. The shells occur both below and above far-transported fragments of rock, and the fundamental granite, limestone, and other rocks, which support the shelly drift of the St. Lawrence and Lake Champlain, are smoothed and furrowed on their surface by glacial action.

In my first memoir on the fossil shells sent to me by Captain Bayfield, from the drift near Quebec, I called attention to the fact, that the number of species was small, while the individuals were numerous, a character belonging to the fauna of seas in high latitudes. At the same time it was shown, that there was a far greater variety in the shells now living in the Gulf of St. Lawrence. Dr. Gould, the eminent conchologist of Boston, suggested to me, that on examining a greater number of localities, especially at wide distances from each other, I might find the number of species gradually to augment. This has not been the case, and when we reflect, that at Burlington in Vermont, which, as before stated, is situated in latitude $44^{\circ} 25^{\prime} \mathrm{N}$., or corresponding to the latitude of Bordeaux in France, we meet with the same assemblage as near Quebec, latitude $46^{\circ} 48^{\prime} \mathrm{N}$., and at some points on the coast of Labrador, in latitude $50^{\circ}$, most of them being identical with fossils of the Scandinavian drift, in latitudes $58^{\circ}$ and $60^{\circ} \mathrm{N}$.; we shall be inclined to acquiesce in the views which I formerly advanced, respecting the prevalence of a colder climate in these regions at the time when the boulder formation originated.

July 5th.-Returning to Montreal after our excursion to Quebec, we crossed the St. Lawrence on 
our way southward to La Prairie. On looking back over the river at Montreal, the whole city seemed in a blaze of light, owing to the fashion here of covering the houses with tin, which reflected the rays of the setting sun, so that every roof seemed a mirror. Behind the city rose its steep and shapely mountain, and in front were wooded islands, and the clear waters of the St. Lawrence sweeping along with a broad and rapid current. At the barracks in La Prairie, a regiment of hussars was exercising-a scene characteristic of the times. On our way to Lake Champlain we slept at St. John's, where I counted under the eaves of the stable of our inn more than forty nests of a species of swallow with a red breast. The head of a young bird was peeping out of each nest, and the old ones were flying about, feeding them. The landlord told me, that they had built there for twenty years, but missed the two years when the cholera raged, for at that time there was a scarcity of insects. Our host also mentioned, that in making an excavation lately near Prattsburg, about 1000 of these birds were found hybernating in the sand : a tale for the truth of which I do not vouch; but it agrees with some old accounts of the occasional hybernation of our swallows in similar situations.

We next crossed Lake Champlain to Burlington, in Vermont, in a steamboat, which, for neatness, elegance, and rapidity, excelled any we had yet beheld. The number of travellers has been sensibly thinned this year by the depressed state of commerce. The scenery of this lake is deservedly much admired. To the west we saw the principal range of 
mountains in the State of New York, Mount Marcy, the highest, attaining an elevation of upwards of 5400 feet. It is still (July 6th) capped with snow, but the season is unusually late. From the survey of this part of New York by Professor Emmons, it appears that hypersthene rock rises up in the central part of this chain, and forms the nucleus, around which masses of gneiss, crystalline limestone, and other formations are disposed. To the eastward were the Green Mountains, chiefly composed of chlorite schist, the Camel's Hump and the still loftier Mount Mansfield, being very conspicuous.

We landed at Burlington, finely situated on the east shore of the lake; its streets adorned with avenues of the locust tree (Robinia pseudo-acacia), now covered with white blossoms, and affording an agreeable shade. After examining the rocks in the neighbourhood, and at the Falls of the Winooski, with Professor Benedict, I crossed the Lake to Port Kent, where, after seeing the boulder formation with shells already described, I went to Keeseville, to examine a deep cleft in the sandstone, through which the Ausable river flows for two miles. This chasm is only from forty to fifty feet in width, while its perpendicular walls are 100 feet high. A flight of wooden stairs has been placed so as to enable one to reach the bottom, and the geologist may observe, as he descends, the numerous horizontal strats of siliceous sandstone. In many places, this most ancient of the fossiliferous rocks of New York (the Potsdam sandstone) is divided into laminæ by the remains of innumerable shells of the genus Lingula. They are in such profusion as to form black seams like mica, for which 
they were at first mistaken.* With the Lingula occurs another small placunoid shell, allied to, if not identical, according to Professor E. Forbes, with a fossil which occurs in company with a small Lingula in the lowest beds of the English Silurian series at Builth, in Brecknockshire. As this is perhaps the most ancient fossiliferous rock of which the position has been well determined in North America, it is highly interesting that one of its commonest organic remains should belong to a living genus (Lingula), and that its form should come very near to species now existing. Throughout so vast a series of ages has Nature worked upon the same model in the organic world! Nor are the signs of uniformity confined to these phenomena, for they extend equally to the shape of the ripple mark on the ledges of sandstone laid open to view above the chasm, where two beautiful waterfalls are seen on the Ausable river. The ripple-like ridges and furrows exhibit their usual parallelism and ramifications as sharp as if they had been made yesterday. On my way back over the lake to Burlington, I saw, on looking from our boat through the clear and shallow water near the shore, a similar ripple in the light yellow-coloured, loose sand, extending over hundreds of acres, and proving that it is not merely on the beach between high and low water mark that the movement of the water can produce those sinuous ridges, but also to a certain depth below.

Some of the freshwater shells inhabiting Lake Champlain are of species peculiar to this lake, as, for example, Limnaa gracilis, specimens of which were

* See Emmons's Report on the Geology of New York, p. 218. 
presented to me by Professor Benedict. Among the flowers and plants which enlivened the borders of this lake was the Virginia raspberry, with its large red blossoms, the Kalmia ( $K$. angustifolia), a beautiful tiger lily, the oderiferous shrub called sweet fern (Comptonia asplanifolia), an Hypericum, and a blue Campanula.

July 9th.-From Burlington, I crossed the Green Mountains of Vermont, composed of chlorite schist, gneiss, and other crystalline rocks, passing by Montpelier, to Hanover. Here we paid a visit to Professor Hubbard, at Darmouth College, and then returned through New Hampshire by Concord to Boston. Since we had left that city in May, we had travelled in little more than two months a distance of 2500 miles on railways, in steamboats, and canoes, in public and private carriages, without any accident, and having always found it possible so to plan our journey from day to day, as to avoid all fatigue and night travelling. We had usually slept in tolerable inns, and sometimes in excellent hotels in small towns, and had scarcely ever been interrupted by bad weather. I infer, from the dismay occasionally expressed by Americans when we pursued our journey, in spite of rain, that the climate of the States must be always as we found it this year-wonderfully more propitious to tourists than that of the "old country," though it is said to be less favourable to the health and complexion of Europeans.

I ventured on one or two occasions in Canada, when I thought that the inns did not come up to the reasonable expectations of a traveller, to praise those of the United States. I was immediately assured VOL. II. 
that if in their country men preferred to dine at ordinaries, or to board with their families at taverns, instead of cultivating domestic habits like the English, nothing would be more easy than to have fine hotels in small Canadian towns. This led me to inquire how many families, out of more than fifty whom we had happened to visit in our tour of eleven months in the United States, resided in boarding-houses. I found that there was not one; and that all of them lived in houses of their own. Some of these were in the northern and middle, others in the southern and western States; some in affluent, others in very moderate circumstances: they comprised many merchants as well as lawyers, ministers of religion, political, literary, and scientific men.

.Families who are travelling in the U. S., and strangers, like ourselves, frequent hotels much more than in England, from the impossibility of hiring lodgings. In the inns, however, good private apartments may be obtained in all large towns, which, though dear for the United States, are cheap as contrasted with hotels in London. It is doubtless true that not only bachelors, but many young married couples, occasionally escape from the troubles of house-keeping in the United States, where servants are difficult to obtain, by retreating to boarding-houses; but the fact of our never having met with one instance among our own acquaintances inclines me to suspect the custom to be far less general than many foreigners suppose.

It was now the fourth time we had entered Boston, and we were delighted again to see our friends, some of whom kindly came from their country resi- 
dences to welcome us. Others we visited at Nahant, where they had retreated from the great heat, to enjoy the sea-breezes. The fire-flies were rejoicing in the warm evenings. Ice was as usual in abundance; the icemen calling as regularly at every house in the morning as the milkman. Pine-apples from the West Indies were selling in the streets in wheelbarrows. I bought one of good size, and ripe, for a shilling, which would have cost twelve shillings or more in London. After a short stay, we set sail in the Caledonia steam-packet for Halifax. 


\section{CHAPTER XXIII.}

Halifax.-Glacial Furrows in Nova Scotia.-Difference of Climate of Halifax and Windsor.-Tracts covered with Kalmia.-Linnaa borealis.-High Tides of the Bay of Fundy.-The Bore.-Recent Deposits of Red Mud hardened in the Sun.-Fossil Showers of Rain.-Footprints of Birds, and Casts of the same.-Cracks caused by Shrinkage.Submerged Forest.-Recent Glacial Furrows at Cape Blomidon.-Loaded Ice.-Ice-Ruts in Mud.

July 16, 1842.-WheN I went on board the Caledonia at Boston, I could hardly believe that it was as large as the Acadia, in which we had crossed the Atlantic from Liverpool, so familiar had I now become with the greater dimensions of the steamers which navigate the Hudson and other large American rivers.

We soon reached Halifax, and I determined to devote a month to the geology of Nova Scotia. About three miles south of Halifax, near "the Tower," I saw a smooth surface of rock, formed of the edges of curved and highly inclined strata of clay-slate. This surface was crossed by furrows about a quarter of an inch deep, having a north and south direction, and preserving their parallelism throughout a space 100 yards in breadth. Similar phenomena are observed in other parts of this peninsula, on the removal of the drift, which occurs both stratified and unstratified, and much resembles that of Scotland. I may mention here, that afterwards 
near Pictou (at Dixon's quarry), I observed polished a surface of quartzose grit of the coal measures, with distinct furrows running nearly $\mathrm{E}$. and W. or E. $15^{\circ}$ N., magnetic; while in some other places I saw them having nearly the same direction as at Halifax.

Nova Scotia is usually known to strangers by its least favourable side,-its foggy southern coast, which has, nevertheless, the merit of affording some of the best harbours in the world. We left Halifax for Windsor in a drizzling rain and fog, and were told that we should probably find fair weather on the other side of the hills. Accordingly, when we had travelled about thirty miles, and crossed a low chain called the Ardoise Hills, we found the sun shining on a region sloping towards the Bay of Fundy, where a rich vegetation clothes the rocks of red sandstone, marl, and limestone.

Great was the contrast between the climate and aspect of this fertile country, and the cold barren tracts of granite, quartzite, and clay-slate which we had passed over on our way from Halifax. The sterility of that quartziferous district had not been relieved by any beautiful features in the scenery, the plants alone affording us some points of interest and novelty, especially a species of Kalmia (K. angustifolia), now in full flower, which monopolised the ground in some wide open spaces, as heaths take exclusive possession of barren tracts in Europe. In the woods near Windsor, I saw several kinds of $P y$ rola and other flowers, differing, for the most part, from British species, but among them the Linncea borealis appeared here and there, matting the ground 
with its green leaves under the shade of the fir-trees, and still displaying some of its delicate pink flowers. I had gathered it some years before in the mountains of Norway, north of Christiania, and have since seen it growing in Scotland, where it is very rare. Linnæus, when this small and elegant plant had been named after him by a friend, accepted it as his emblem, comparing it to himself when struggling with difficulties; he described it as " a humble, despised and neglected Lapland plant, flowering at an early age." Eventually, the last only of these points of resemblance remained true, for few men of science have risen to greater honours in their own country than he did, and his diary has laid him open to the charge of no ordinary share of vanity, a fault which we forget in our admiration of his original genius, and the important reforms which he introduced into the study of every branch of natural history.

More than half of the southern portion of the peninsula of Nova Scotia consists of granitic rocks, clay-slate, quartzite, and other crystalline formations without fossils, the strata having an east and west strike. Granite also occurs, intruding itself in veins into every part of this series. Towards their northern limits, the slaty formations become less metamorphic, and contain fossils, some of which I collected at New Canaan near Wolfville in King's County, and others on the East River of Pictou, consisting of Encrinites, and Trilobites, and shell of the genera Orthoceras, Spirifer, Orthis, and Leptcena. Some few of them agree specifically with fossils of the Hamilton group or uppermost Silurian division of the United States, No. 10 of map, Pl. II. 
After crossing the Ardoise Hills above mentioned, I left these older rocks, and entered upon strata which constitute, as I shall show in the sequel (ch. 25), a lower carboniferous formation, containing subordinate beds of gypsum and marine limestone. These rocks I examined on the banks of the Avon, in the neighbourhood of Windsor, and in the cliffs at Horton Bluff. I then passed by Kentville and Cornwallis, skirting the western shores of the Basin of Mines. Into this basin, or inner estuary, the tides of the Bay of Fundy pour twice every day a vast body of water through a narrow strait, converting every small streamlet into the appearance of a large tidal river. The tides are said to rise in some places seventy feet perpendicular, and to be the highest in the world. They often come up at first with a lofty wave called the Bore, of which I saw a fine example in the largest river of Nova Scotia, the Shubenacadie, where the waters seemed to be rushing down a much steeper slope than the St. Lawrence at its rapids. They roared too as loudly over their rocky bed, but could not compete in beauty; for instead of the transparent green waters and white foam of the St. Lawrence, they resembled a current of red mud in violent motion.

The waters of the Bay of Fundy become charged with this red sediment, by undermining cliffs of red sandstone and soft red marl; and in places where they overflow the alluvial plains, they throw down red mud wherever the velocity of the current is suspended at the turn of the tide. Many extensive and level flats of rich land have been thus formed naturally, and many thousand acres of the same have 
been exciuded artificially from the sea by embankments. When I arrived in this region it was the period of the lowest or neap tides, so that large areas, where the red mud had been deposited, were laid dry, and in some spots had been baking in a hot sun for ten days. The upper part of the mud had thus become hard for a depth of several inches, and in its consolidated form exactly resembled, both in colour and appearance, some of the red marls of the New Red sandstone formation of Europe. The upper surface was usually smooth, but in some places I saw it pitted over with small cavities, which I was told were due to a shower of rain which fell eight or ten days before, when the deposit was still soft. It perfectly recalled to my mind those "fossil showers" of which the markings are preserved in some ancient rocks, and the origin of which was first correctly explained to an incredulous public by Dr. Buckland in 1833. I have already alluded to such impressions of rain-drops when speaking of the ripple-marked flags of the New Red sand-stone at Newark in New Jersey. I saw several other examples, during my tour, of similar phenomena, particularly in a bright red deposit of mud thrown down at the mouth of the Patapsco at Baltimore, of which I was able to bring away some consolidated layers. On these, in addition to the smaller cavities due to rain, there are larger ones, more perfectly circular, about the size of large currants, which have been formed by air-bubbles in the mud.

On the surface of the dried beds of red mud at Wolfville on the Bay of Fundy before mentioned, I observed many worm-like tracks, made by Annelides 
which burrow in the mud; and, what was still more interesting to me, the distinct footmarks of birds in regular sequence, faithfully representing in their general appearance the smaller class of Ornithicnites of high antiquity in the valley of the Connecticut before described. (Vol. I., p. 252).

I learnt from Dr. Harding of Kentville, and $\mathrm{Mr}$. Pryor of Horton, who were my guides, that these recent footprints were those of the sandpiper (Tringa minuta), a species common to Europe and North America, flights of which I saw daily running along the water's edge, and often leaving thirty or more similar impressions in a straight line, parallel to the borders of the estuary. The red mud had cracked in hardening in the sun's heat, and was divided into compartments, as we see clay at the bottom of a dried pond, and I was able to bring away some pieces to England. One of these I have figured in the annexed plate (VII.). In fig. 1 we see the upper surface of the slab, on the left side of which are six perfect foot-marks in the same line, with part of a seventh, and another, $a$, probably belonging to a distinct line. A small ball or protuberance will be seen near the base of the middle toe, as at $a, b$, or sometimes about the middle of the impression of the middle toe, as at $c$. This is caused by the mud which is displaced by the prominent metatarsus or instep bone, which has thrust forward a small mound of earth, in consequence of the slanting position of the leg as the bird advances. On splitting the slab, and reducing it to the thickness expressed in the transverse section, fig. 3, I was fortunate enough to lay open an under surface, on which two other lines of foot-prints 
appeared in relief, fig. 2. These are the casts of impressions which had been made on an inferior layer, deposited several tides before; and I ascertained that on the upper and under surfaces of several other thin laminæ, shown in the cross section No. 3, there exist similar foot-marks, each set made by birds at different times. It will be seen that the toes which are indented in No. 1, are represented by protuberances in No. 2, and that at $d$ the mark of a single toe occurs in relief, and quite isolated. This occurrence was not unfrequent, and Mr. Waterhouse has suggested to me in explanation that these waders, as they fly near the ground, often let one leg hang down, so that the longest toe touches the surface of the mud occasionally, leaving a single mark of this kind. The slabs here figured have been presented by me to the British Museum, in order that those naturalists who are still very sceptical as to the real origin of the ancient fossil ornithicnites, of which there are some fine examples in our national repository, may compare the fossil products of the month of July, 1842, with those referable to feathered bipeds which preceded the era of the Icthyosaurus, Iguanodon, and Pterodactyl.

On several wide areas, comprising many hundreds of acres each, I saw the surface of the red mud fissured in all directions by the shrinkage accompanying desiccation, and I was surprised to find some of the cracks several inches wide, and no less than two or three feet deep. Occasionally, a fresh tide had deposited sediment in the older cracks, filling them up, and this mud having in its turn become hardened, together with a new contemporaneous superficial 

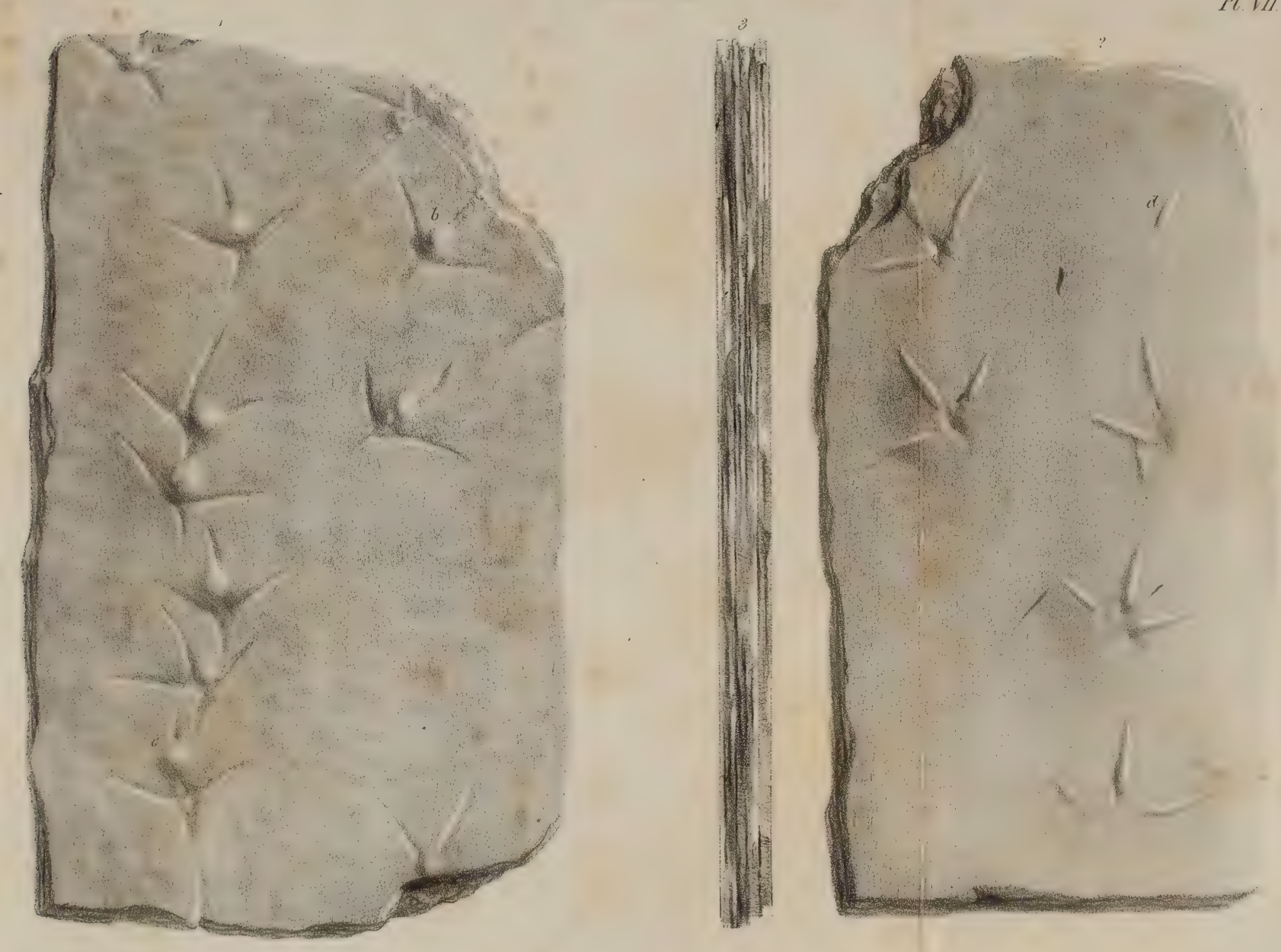

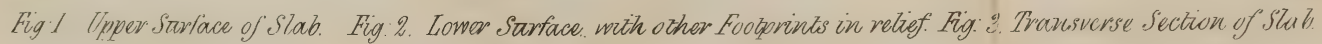


Imy dear, thother m Rear 
layer, I found, on taking up the slab, the casts of the old fissures standing out in relief, as we occasionally see them on the under surfaces of flags of sandstone, which rest on layers of clay or shale.

Before quitting the subject, I may state that hard nodules of a red clay-ironstone are occasionally met with in the red mud, some of which I was shown as having been found near Minudie at low water. The nucleus of the concretion often consisted of recent littoral shells, Mya arenaria and Tellina grœnlandica. I was also informed that there was a submerged forest buried in this red mud, and exposed to view in the Cumberland Basin at low tide, not far from Fort Cumberland. I regret that I had no time to examine this forest of upright trees, as the accounts I received of it appeared to imply that there must have been some subsidence of land in modern times. In estimating the changes in progress in nature's laboratory beneath the sea, we must not forget that by far the greater part of the red sediment of the Bay of Fundy is carried out by a strong current into the depths of the Atlantic.

July 24.-Continuing my course along the western borders of the Basin of Mines, I at length reached Cape Blomidon, where cliffs of soft red sandstone, in nearly horizontal beds, are capped by a mass of basalt, greenstone, and amygdaloid. This mass of igneous rock, after presenting fine ranges of rude columns in the bold precipices facing northwards, is continuous, in a narrow strip of high land, for no less than 130 miles east and west, extending as far as Annapolis, and beyond it to Briar Island. Its structure and characteristic minerals have been well described 
by Messrs. Jackson and Alger, in their elaborate paper, read in the year 1831, to the American Academy.* Although this trap is generally parallel to the subjacent red sandstone, it appears in reality to form a great dyke rather than a contemporaneous bed.

As I was strolling along the beach at the base of these basaltic cliffs, collecting minerals, and occasionally recent shells at low tide, I stopped short at the sight of an unexpected phenomenon. The solitary inhabitant of a desert island could scarcely have been more startled by a human foot-print in the sand, than I was on beholding some recent furrows on a ledge of sandstone under my feet, the exact counterpart of those grooves of ancient date which I have so often described in this work, and attributed to glacial action. After having searched in vain at Quebec (see p. 120) for such indications of a modern date, I had despaired of witnessing any in this part of the world. I was now satisfied that, whatever might be their origin, those before me were quite recent.

The inferior beds of soft sandstone, $a, a$, fig. 16, which are exposed at low water at the base of the cliff at Cape Blomidon, form a broad ledge of bare rock, to the surface of which no sea-weed or barnacles can attach themselves, as the stone is always wearing away slowly by the continual passage of sand and gravel, washed over it from the talus of fallen fragments, $d$, which lies at the foot of the cliff on the beach above. The slow but constant under-

* On the Mineralogy and Geology of Nova Scotia. Mem. of Amer. Acad. of Arts and Sci., vol. i., New Series, 1833. Cambridge, Mass. 
Fig. 16.

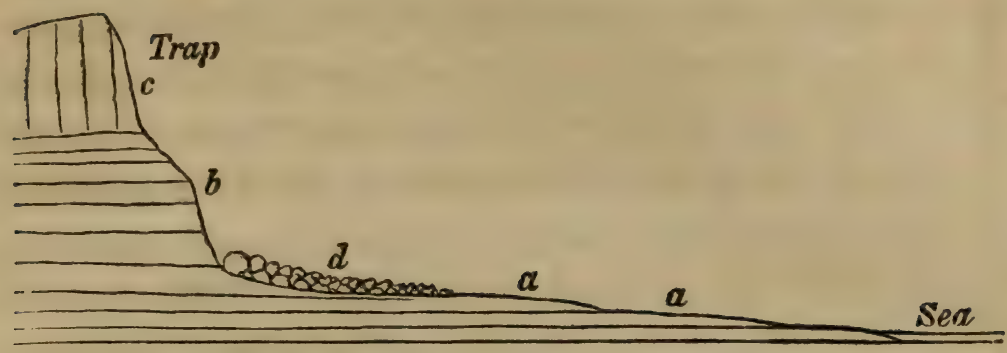

Section of the Cliff and Beach at Cape Blomidon.

$a, a$. Ledges of soft sandstone exposed at low water.

b. Red marls with light greenish streaks, and layers of fibrous gypsum.

c. Capping of trap.

d. Talus of blocks and pebbles of trap, amygdaloid, greenstone, \&c.

mining of the perpendicular cliff forming this promontory, round which the powerful currents caused by the tide sweep backwards and forwards with prodigious velocity, must satisfy every geologist that the denudation by which the ledge in question has been exposed to view is of modern date. Whether the rocks forming the cliff extended so far as the points $a, 10,50$, or 100 years ago, I have no means of estimating; but the exact date and rate of destruction

Fig. 17

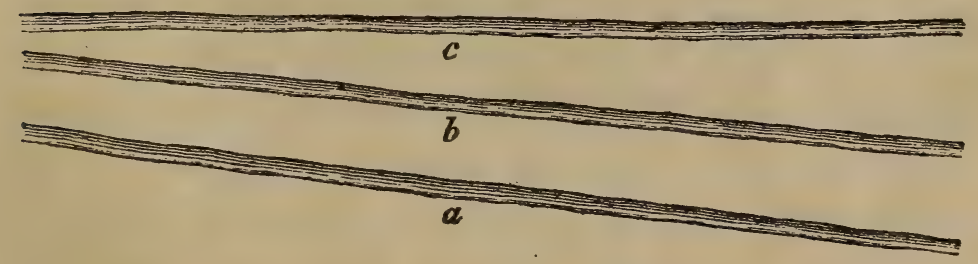

Recent furrows on ledge of sandstone at Cape Blomidon.

are immaterial. On this recently formed ledge, I saw several straight furrows half an inch broad, some of them very nearly parallel, as $a, b, f i g .17$, others diverging, as $c$, the direction of $a, b$, being $\mathrm{N} .35^{\circ} \mathrm{E}$., 
or corresponding to that of the shore at this point. After walking about a quarter of a mile, I found another set of similar furrows, having the same general direction within five degrees; and I made up my mind that if these grooves could not be referred to the modern instrumentality of ice, it would throw no small doubt on the glacial hypothesis. When I asked my guide, a peasant of the neighbourhood, whether he had ever seen much ice on the spot where we stood, the heat was so excessive (for we were in the latitude of the south of France, $45^{\circ} \mathrm{N}$.) that I seemed to be putting a strange question. He replied that in the preceding winter of $\mathbf{1 8 4 1}$ he had seen the ice, in spite of the tide, which ran at the rate of 10 miles an hour, extending in one uninterrupted mass from the shore where we stood to the opposite coast at Parrsborough, and that the icy blocks, heaped on each other, and frozen together or "packed," at the foot of Cape Blomidon, were often fifteen feet thick, and were pushed along when the tide rose, over the sandstone ledges. He also stated that fragments of the "black stone" which fell from the summit of the cliff, a pile of which, $d$, fig. 16, lay at its base, were often frozen into the ice, and moved along with it. I then examined these fallen blocks of amygdaloid scattered round me, and observed in them numerous geodes coated with quartz crystals. I have no doubt that the hardness of these gravers, firmly fixed in masses of ice, which, although only fifteen feet thick, are often of considerable horizontal extent, have furnished sufficient pressure and mechanical power to groove the ledge of soft sandstone.

In Nova Scotia the term "loaded ice" is in 
common use for large sheets of ice several acres in area, which are sometimes floated off from the rivers as the tide rises, with sedge and other salt-marsh plants frozen into their lower surfaces; also with mud adhering plentifully to their roots. In our speculations, therefore, on the carrying power of ice, we ought always to remember that, besides gravel and large fragments of rock, it transports with it the finest mud.

Dr. Harding informed me that the surface of mudbanks along the estuaries near Wolfville, are often furrowed with long, straight, and parallel ruts, as if large waggons had passed over them. These conform in their general direction to the shore, and are produced by the projecting edges of irregular masses of packed ice, borne along by the tidal current. 


\section{CHAPTER XXIV.}

Coal Formation of Nova Scotia.-Productive Coal Measures.Erect Fossil-Trees in the Cliffs of the Bay of Fundy.-Section from Minudie to the South Joggins. - Ten buried Forests, one above the other.-Connection of upright Trees with Seams of Coal.-Stigmaria._Sigillaria._Evidence of Repented Submergence of dry Land.-Theory to explain the Evenness of the Ancient Surface.-Pictou Coal-field.-Bed of Erect Calamites, compared to those of St. Etienne, in France.-List of Species of Nova Scotia Coal-plants.-Four-fifths of these Fossils identified with European Species.-Carboniferous Flora of the United States.

Авоve the granite, clay-slate, quartzite, and Silurian formations of Nova Scotia, there occur, in the northern part of the peninsula, as stated in the last chapter, strata referable to the carboniferous group, occupying very extensive tracts, and resting unconformably on the rocks of the older series. They may be divided into three formations; the middle one, comprising the productive coal-measures, agreeing precisely with those of Europe in their lithological characters and organic remains ; an upper one, composed of sandstone and shale with fossil plants, but without coal; and a lower carboniferous group, chiefly made up of red sandstone and red marl, with subordinate beds of gypsum and marine limestone. In this lower series there are also occasionally some beds of shale with plants, and some coal-grits, and thin seams of impure coal.

A variety of opinions have been entertained re- 
specting the true age and position of the last-mentioned or gypsiferous formation, which has been generally presumed to be newer than the coal,-by some referred to the New Red sandstone, and even thought to overlie the coal-measures unconformably. Immediately after my return to England, I commu- nicated to the Geological Society my opinion; 1st, that the gypsiferous formation, with its accompanying fossiliferous limestones, is a true member of the Carboniferous group ; 2dly, that its position is below the productive coal measures.*

I shall now give some account of these middle or productive coal measures, which contain valuable seams of bituminous coal, at various places, especially near Pictou. I was particularly desirous, before I left England, of examining the numerous fossil trees alluded to by Dr. Gesner as imbedded in an upright posture at many different levels in the cliffs of the South Joggins, near Minudie. The cliffs belong to the Cumberland coal-field, on the southern shores of a branch of the Bay of Fundy, called the Chignecto Channel, which divides part of New Brunswick from Nova Scotia. The first allusion to the trees which I have met with, is that published in 1829 by Mr. Richard Brown, in Halyburton's Nova Scotia, and he attributed their fossilisation to the inundation of the ground on which the forests stood. I felt convinced that, if I could verify the accounts of which I had read, of the superposition of so many different tiers of trees, each representing forests which grew in succession on the same area, one above the other;

* See Proceedings of Geol. Soc., vol. iv., p. 184. 1843. 
and if I could prove at the same time their connexion with seams of coal, it would go farther than any facts yet recorded to confirm the theory that coal in general is derived from vegetables produced on the spots where the carbonaceous matter is now stored up in the earth.

At Wolfville I hired a schooner, which soon carried us across the Basin of Mines to Parrsborough. We had a side wind, and the deck was inclined at about an angle of $45^{\circ}$, in spite of which we admired a splendid view of the coast, and the range of basaltic rocks which extend from Cape Blomidon to Cape Split. At Parrsborough I was joined by Dr. Gesner, who had come expressly from New Brunswick to meet me; and we went together to Minudie, a thriving village, where we were hospitably received by the chief proprietor and owner of the land, and of many of those fertile flats of red mud before described, which he has redeemed from the sea.

From Minudie, a range of perpendicular cliffs extends in a south-westerly direction along the southern shore of what is commonly called the Chignecto Channel. The general dip of the beds is southerly, and the lowest strata near Minudie consist of beds of red sandstone, with some limestone and gypsum, $a, b$, fig. 18. The section is then very obscure for about three miles, or from $b$ to $c$, the rocks consisting chiefly of red sandstone and red marl, after which, at $c$, blue grits are seen, inclined to the S.S.W. at an angle of $27^{\circ}$, affording an excellent grindstone, and attaining a thickness of forty-four feet. These beds are succeeded to the south by a vast series of newer and conformable strata, all dipping the same way, 
Chap. xxiv. ERect fossil trees.

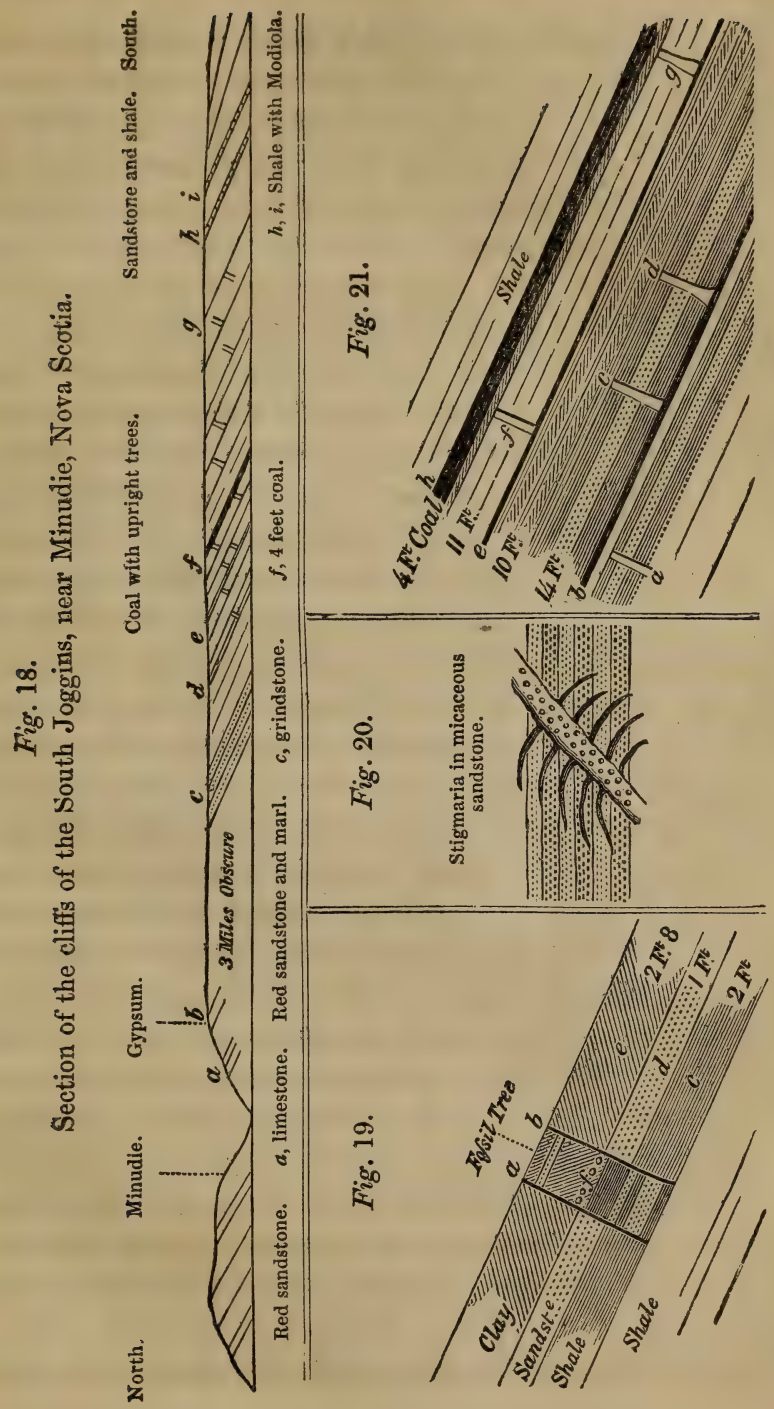


and, for the first three miles which I examined, inclined nearly at the same angle, upon an average about $24^{\circ}$ S.S.W. Within this space, or between $d$ and $g$, all the upright trees hitherto found occur; but the same set of strata is still continuous, with a gradually lessening dip, many miles farther to the south.

If we assign a thickness of four or five miles to this regular succession of carboniferous strata, which, as I shall afterwards show, must have been originally quite horizontal, our estimate will probably be rather under than over the mark. For the first mile south of the grindstones, or from $c$ to $d$, I observed no coal in the cliffs, after which the first of the upright trees appears at $d$, at the distance of about six miles from Minudie. Then followed a series of coal-bearing strata, consisting of white freestone, bituminous shale, micaceous sandstone, sandy clays, blue shale, and clays with and without nodules of ironstone, all resembling the carboniferous rocks of Europe. They occupy a range of coast about two miles long, the vertical height of the cliffs being from 150 to 200 feet; and about nineteen seams of coal have been met with, which vary in thickness from two inches to four feet. At low tide, we had not only the advantage of beholding a fine exposure of the edges of these beds in the vertical precipices, but also a horizontal section of the same on the beach at our feet.

The beds through which erect trees, or rather the trunks of trees, placed at right angles to the planes of stratification, are traceable, have a thickness of about 2500 feet; and no deception can arise from the repetition of the same beds owing to shifts or 
faults, the section being unbroken, and the rocks, with the exception of their dip, being quite undisturbed. The first of the upright trees which I saw, in the strata $d$, fig. 18 , is represented in the enlarged section, fig. 19. No part of the original plant is preserved except the bark, which forms a tube of pure bituminous coal, filled with sand, clay, and other deposits, now forming a solid internal cylinder without traces of organic structure. The bark is a quarter of an inch thick, marked externally with irregular longitudinal ridges and furrows, without leaf-scars, and therefore not resembling the regular flutings of Sigillariæ, but agreeing exactly with the description of those vertical trees which are found at Dixonfold, on the Bolton railway, of which Messrs. Hawkshaw and Bowman have given an excellent account in the Proceedings of the Geological Society.* On comparing Mr. Hawkshaw's drawings of the British fossils, in the library of the Geological Society, as well as a specimen of one of the Dixonfold trees presented by him to their museum, with portions of the bark brought by me from Nova Scotia, I have no hesitation in declaring them to be identical.

The diameter of the tree, $a . b$, fig. 19, was fourteen inches at the top and sixteen inches at the bottom, its height five feet eight inches. The strata in the interior of the tree consisted of a series entirely different from those on the outside. The lowest of the three outer beds which it traversed consisted of purplish and blue shale, $c$, fig. 19, two feet thick, above which was sandstone, $d$, one foot thick, and

* London, 1839-40; vol. iii, pp. 139, 270. 
above this clay, $e$, two feet eight inches. In the interior, on the other hand, were nine distinct layers of different composition: at the bottom, shale four inches; then, in the ascending series, sandstone one foot, shale four inches, sandstone four inches, shale eleven inches, clay with nodules of ironstone, $f$, two inches, pure clay two feet, sandstone three inches, and, lastly, clay four inches.

Mr. Bowman has explained in the Manchester Transactions the causes of the frequent want of correspondence in the strata enclosing a buried tree, and the layers of mud and sand accumulated in the interior, which vary according to the more or less turbid state of the water at the periods when the trunk decayed and became hollow, and according to the height to which it was prolonged upwards in the air or water after it began to be imbedded externally in sediment, and various other accidents. It is not uncommon to observe in Nova Scotia, as in England, that the layers of matter in the inside are fewer than those without. Thus, a "pipe" or cylinder of pure white sandstone, representing the interior of a fossil tree, will sometimes intersect numerous alternations of shale and sandstone. In some of the layers in the inside of the trunk, $a, b$, fig. 19, and in other trees in this line of cliffs, I saw leaves of ferns and fragments of plants which had fallen in together with the sediment.

Continuing my survey, I found the second of the erect trees, e. fig. 18, or $a$, fig. 21, separated from the first, or from $a, b$, fig. 19, by a considerable mass of shale and sandstone. This second trunk was about nine feet in length, traversing various strata, and cut 
off at the top by a layer of clay two feet thick, on which rested a seam of coal, $b$, fig. 21 , one foot thick. This coal formed a foundation on which stoud two large trees, $c$ and $d$, fig. 21, about five yards apart, each about two and a half feet in diameter, and fourteen feet long, both enlarging downwards, and one of them, $d$, bulging considerably at the base. The beds through which they pass consist of shale and sandstone. The cliff was too precipitous to allow me to discover any commencement of roots, but the bottom of the trunks seemed to touch the subjacent coal. Above these trees were beds of bituminous shale and clays with Stigmaria, ten feet thick, on which rested another bed of coal, $e$, one foot thick, and this coal supported two trees, $f$, $g$, each eleven feet high, and sixty yards apart. They appeared to have grown on the coal, e. One of these, about two feet in diameter, preserved nearly the same size from top to bottom, while the other, which was about fourteen inches in diameter at the top, enlarged visibly at the base. The irregular furrows of the bark were an inch and half one from the other. The tops of these trees were cut off by a bed of clay, on which rested the main seam of the South Joggins coal, four feet thick, above which is another succession of strata, very similar to those already described, with occasional thin seams of coal, and with vertical trees at five or six different levels.

I observed in all at least seventeen of these upright trunks, but in no instance did I see any one of them intersecting a layer of coal, however thin, nor did I find any one of them terminating downwards in sandstone, but always in coal or shale. Their 
usual height was from six to eight feet, but one which was more than a hundred feet above the beach, and which I could not approach to measure, seemed to be twenty-five feet high, and four feet in diameter, with a considerable bulge at the base. They all appear to be of one species, the rugosities on the surface producing the effect of a rudely-fluted column, and they were placed very accurately at right angles to the planes of stratification. I found numerous flattened trunks of large Sigillariæ with their flutings and leaf-scars in the shales, but none of them resembled the erect trees with their irregularly furrowed exterior.

Stigmariæ are abundant in the argillaceous sandstones of these coal-measures, often with their leaves attached, and spreading regularly in all directions from the stem. It commonly happens here, as in Europe, that, when this plant oecurs in sandstone, none of its leaf-like processes (or rootlets?) are attached, but I saw one remarkable exception in strata of micaceous sandstone, between the site of the upright tree represented in fig. 19 and those given in fig. 21. The stem was about four inches thick (see fig. 20), and it traversed obliquely several layers of fine white micaceous sandstone two feet in vertical thickness. Mr. Binney of Manchester seems now to have proved that these Stigmariæ are really the roots of Sigillaria, by finding them actually proceeding from the bottoms or stools of the trunks of Sigillariæ which occur erect in the British coal-measures. We may therefore conclude that the dome-shaped mass represented by Messrs. Lindley and Hutton in their Fossil Flora, pl. 31, and figured by Dr. Buckland in 
his Bridgewater Treatise, pl. 56, vol. ii., was nothing more or less than a section of the stump of a fossil Sigillaria, from which the roots extended in all directions through the ancient soil. It should be remembered that M. Adolphe Brongniart, when he obtained from Autun the first and only example yet discovered of a Sigillaria exhibiting internal structure, pronounced it to agree so nearly with Stigmaria, that he inferred on botanical considerations alone, that both must belong to the same plant, and that the Stigmaria was probably the root. In some of the specimens of the latter plant obtained in Nova Scotia, and cut in thin slices so as to transmit light, the woody fibre of the internal cylinder surrounding the axis from which the pith has disappeared, shows, under the microscope, the vascular tissue, and the fern-like or scalariform vessels, which are so conspicuous in European Stigmariæ. By aid of the silicified fossil from Autun, M. Ad. Brongniart has been enabled to demonstrate that this structure, or the scalariform vessels, so distinguishing a character of the living Ferns and some other cryptogamous plants, is united in Sigillaria with rings of growth peculiar to dicotyledonous trees, so that we have here, in this extinct genus, a link between classes of plants standing widely apart from each other in the arrangement of existing vegetables.

I have stated that I counted seventeen upright trees in the strata of the South Joggins, and I was assured by Dr. Gesner, and by residents at Minudie, that other and different individuals were exposed a few years ago ; the action of the tides of the Bay of Fun$\mathrm{dy}$ being so destructive as continually to undermine and sweep away the whole face of the cliffs, so that

VOL, II.

15 
a new crop of fossils is laid open to view every three or four years. I saw the erect trees at more than ten distinct levels, one above the other; they extend over a space of two or three miles from north to south, and more than twice that distance from east to west, as I am informed by Dr. Gesner, who has explored the banks of streams intersecting this coal-field. For the names of Sigillariæ, Lepidodendra, Ferns, and Calamites collected by me in the cliffs of the South Joggins, and in other coal-measures of Nova Scotia, I refer to the list given at the end of this chapter, calling the reader's attention to the extraordinary amount of specific identity in fossils so widely separated from each other in their "habitations." It appears that, out of forty-eight species, without enumerating the different kinds of Stigmaria, which agree perfectly with the varieties found in England, there are no less than thirty-seven which have been identified. The greater part of the remaining eleven might perhaps have been found to agree with known European fossils, had not most of the specimens been in too imperfect a state to admit of close comparison.

Out of fifty-three species obtained by me from the coal-fields of the United States (almost all of them from Pennsylvania, Maryland, and Ohio), I have been able to identify thirty-five with European fossils, chiefly species found in Great Britain. Of the remaining eighteen, only four can be said to be peculiar forms, the other fourteen being all closely allied species, or geographical representatives of European coal plants. When it is considered that all the gene$r a$ of these fossils are likewise common to North America and Europe, we seem entitled to declare, 
that so great a degree of uniformity in the flora of regions equally remote is without parallel, whether in the more ancient strata or in the geographical distribution of plants, in the present condition of the globe.

Continuing our survey of the cliffs of the South Joggins, we observe, not far above the uppermost coal-seams with vertical trees, or, $g$, fig. 18, two strata, $h, i$, perhaps of freshwater or estuary origin, composed of black calcareo-bituminous shale, chiefly made up of compressed shells, of two species of Modiola and two kinds of Cypris. Above these beds are innumerable strata of red sandstone or shale, without coal seams, and with few or no fossils, on which it will be unnecessary to dwell.

Many curious conclusions may be deduced from the facts above enumerated.

1st. The erect position of the trees, and their perpendicularity to the planes of stratification, imply that a thickness of several thousand feet of strata, now uniformly inclined at an angle of $24^{\circ}$, were deposited originally in a horizontal position. But for the existence of the upright trees it might have been conjectured, that the beds of sand and mud have been thrown down at first on a sloping bank, as sometimes happens in the case of gravel and coarse sand. But, if we are compelled to assume the original horizontality of beds 2500 feet thick, through which the erect trees are dispersed, we can hardly avoid extending the same inference to the greater part of the strata above and below them. It by no means follows that a sea four or five miles deep was filled up with sand and sediment. On the contrary, repeated subsidences, such as are required to explain 
the successive submergence of so many forests which grew one above the other, may have enabled this enormous accumulation of strata to have taken place in a sea of moderate depth.

Secondly. The evidence of the growth of more than ten forests of fossil trees superimposed one upon the other prepares us to admit more willingly the opinion, that the Stigmaria with its root-like processes was really the root of a terrestrial plant fossilised in situ. Yet, if we embrace this opinion, it follows that all the innumerable underclays with Stigmariæ in North America and Europe, which I have alluded to at pp. 62 and 84, Vol. I., and p. 15, Vol. II., \&c., are indications of an equal number of soils, whether of dry land or freshwater marshes, which supported a growth of timber, and were then submerged. If this be true, and the conclusion seems inevitable, the phenomenon of the upright trees in Nova Scotia, marvellous as it may be, shrinks into insignificance by comparison.

At the same time, it is quite intelligible, that we should find hundreds of cases where the soil has remained with the roots fixed in their original matrix for one instance where the trunk has continued to stand erect after submergence. Many favourable circumstances must concur, to allow of such an exception to the general rule. There must, for example, be an absence of waves and currents of sufficient strength to loosen and overturn the trees, and the water must be charged with sediment ready to envelope the plants before they have had time totally to decay. I have shown (p. 164, Vol. I.) that on the coast of S. Carolina and Georgia the land has sunk 
in modern times, and that buried trees are occasionally found in strata containing shells of recent species. The formation of low islands of sand off the shore, breaking the force of the Atlantic, has probably allowed many of these trees near the mouths of estuaries to continue erect under water, until they were silted up and preserved. Similar low islands and sandbanks skirt nearly the whole of the eastern coast of the United States, and may assist the geologist in explaining some of the phenomena of the Carboniferous period, especially the manner in which superficial beds of vegetable matter, as well as upright trees, escaped the denuding forces.

Thirdly. It has been objected to the theory which refers the origin of seams of pure coal to plants which grew on the exact spaces where we now find coal, that the surfaces of ancient continents and islands ought to undulate like those we now inhabit. Where, they ask, are the signs of hills and valleys, and those river-channels which cut through deltas? These apparent difficulties will, I think, be removed, if we reflect that the fossilisation of successive forests presupposes both the subsidence of the ground and the deposition of sediment going on simultaneously. If so, the accumulation of mud and sand furnishes us with the levelling power required, and, had there been extensive denudation capable of producing valleys, it could readily have swept away all the coal. In regard to ancient river-courses, the late $\mathrm{Mr}$. Buddle often assured me, that he had in many places met with them in the coal-fields of the North of England, and he has given a detailed account of one which intersected a seam of coal in 
the Forest of Dean. Even in these cases, however, the general evenness of the surface is immediately restored by a new sinking of the delta, and the deposition of fresh sediment, so that the succeeding seam of coal has grown on as perfectly flat a surface as if there had been no partial destruction of the beds below.

If it be objected that, according to the analogy of recent subterranean movements, some areas ought to have sunk down at a more rapid rate than others, producing irregularities in the ancient level of the dry land, we reply, that there are abundant proofs in the arrangement of the carboniferous strata, that the amount of local subsidence was actually not uniform. Mr. Bowman has clearly pointed out, that the wedge-shaped or lenticular masses of sandstone and shale, which sometimes intervene between the upper and lower portions of a seam of coal, are the natural result of such inequalities in the downward movement. In those areas which sink so fast as to be submerged, the growth of terrestrial plants is suddenly arrested, and the depressed region becomes the receptacle of sediment, until its level is again raised. Then the growth of the former vegetation is resumed, and the result is the intercalation of strata for a certain space between two beds of coal, which unite and become one, if they are followed to a certain distance in every direction.

In our excursion to the fossil trees, Dr. Gesner and I were joined by several volunteers, some of whom separated from us on their way home. I asked a cottager, whether he had seen them pass. He said, that "a party of Jogginers on horseback 
had come by his house half an hour before." As I had heard of a North Joggins on the other side of the bay, I asked whether there was any meaning in this term. He immediately pointed to the salient and retiring angles of the cliffs, observing, "You see that they jog in and jog out."

The coal-field of Pictou, the only one in Nova Scotia where a large quantity of the valuable mineral has been worked, lies about a hundred miles to the eastward of the Cumberland or Minudie coalmeasures. An examination of the strata of the Albion Mines, near Pictou, convinced me that the coal-bearing formation there is the equivalent of that already described, although it may be impossible to identify the different strata in detail. They contain the same fossil plants, and similar shales, with the same species of Modiola and Cypris, as at the South Joggins. At the latter place, the largest seam is only four feet thick, whereas that at the Albion mines is estimated at thirteen yards in thickness. In both localities there is a vast series of beds of red sandstone and red marl, with limestone and gypsum underlying the principal coal-seams, and an enormous thickness of sandstones and shales, without coal, above them.

The only spot in the Pictou coal-field where plants have been observed in an erect position is at Dickson's Mills, a mile and a quarter west of Pictou. Here a bed of upright Calamites were discovered by Mr. J. W. Dawson, with whom I visited the locality. But the section in 1842 was almost entirely concealed by water. The strata consisted of red and grey sandstones and shales, with imbedded fern 
leaves, and numerous fragments of Calamites and Sternbergia. The sandstone in which the upright Calamites were enveloped was about ten feet thick, and all these terminated downwards at the same level, where the sandstone joined a layer of coarse grey limestone with pebbles. The tops of the Calamites were broken off at different heights, where the grit became coarser. Mr. Dawson states that he observed in the same bed, in a prostrate position, a lepidodendron, with leaves and lepidostrobi attached to its branches.

Since my excursion to Nova Scotia, I have examined the French coal-field of St. Etienne near Lyons, where M. Alexandre Brongniart first described a great bed of erect Calamites, inclosed in sandstone, which he believed to have grown where they have become fossil. The section of the beds of which he published a drawing, representing the erect fossil stems, has been since entirely destroyed by the quarrying away of the sandstone, but I obtained so much evidence, in 1843 , of the occurrence of various upright trees, Sigillariæ and others, at different levels in the same coal formation, as to incline me fully to believe M. Alex. Brongniart's conclusions, and to retract the objections I formerly urged against his inferences, on the ground of the different heights at which the Calamites terminated downwards.* This may perhaps be explained by a slight obliquity in the direction of the trunks, or a want of perpendicularity in the vertical face of the cliffs to the planes of stratification.

* See Elements of Geol, vol. ii , p. 137. 
The following list of plants comprises several species which I did not meet with in Nova Scotia, but which occur in the neighbouring island of Cape Breton, and were presented, at different times, to me and to the Geological Society, by Mr. Richard Brown. For several specimens from Nova Scotia I have been indebted to Mr. J. W. Dawson, of Pictou, and to Mr. Alison, F.G.S. I have also included in the catalogue one or two fossils from the New Brunswick coal-field (which may be considered as another part of that near Minudie) presented to the Geological Society by Mr. Henwood.

In determining the specific characters and names, I have been principally indebted to Mr. Samuel Woodward, of the Geological Society, who has been occasionally assisted by Mr. Morris, and I have referred, in some points of difficulty, to M. Adolphe Brongniart. After the list was completed, it was revised, as far as relates to the ferns, by Mr. Chas. Bunbury, some of whose corrections have been adopted, and his comments cited.

LIST OF FOSSIL PLANTS FROM TIE COAL MEASURES OF NOVA SCOTIA AND CAPE BRETON.

NAMES OF FOSSIL PLANTS.

1. Flabellaria Sternb.

Fragments of large palm-like leaves, such as are figured by Sternberg under the name of Flabellaria, are common in many British and

- Continental localities.

2. Cyperites Lindl.

Identical with the grass-like leaves of C. bicarinata, as far as the specimens admit of comparison.
LOCALITIES.

Horton Bluff, near Windsor, South Joggins, and Pictou in Nova Scotia.

Cape Breton. 
NAMES OF FOSSIL PLANTS.

3. Trigonocarpum Brongn.

An undescribed and new species of this genus, so common in the European coal-fields, was given me by Mr. Dawson.

4. Artisia approximata Brong. This plant (the Sternbergia of Brong.) is considered by Mr. Dawes as the cast of the medullary cavity of stems of trees. Quarterly Journ. Geol. Soc., No. 1, p. 91.

5. Asterophyllites, allied to A. tuberculata.

Mr. Binney considers the specimen from Sydney to differ from A. tuberculata, but to be identical with a species found at Manchester.

6. A. galioides? Lindl. British.

7. Sphenophyllum Schlottheimii ? Brong.

A common British coal plant, of which I found only one specimen.

8. Pinnularia capillacea Lindl. Also British.

9. Lepidophyllum lanceolatum (Lindley and Hutton) t. 7. fig. 3, 4.

Also British species.

10. Lepidodendron Rhodianum Sternberg.

Also British.

11. L. obovatum Sternberg, t. 6. f. 1 ; Lindley and Hutton, pl. 19, bis.

\section{Also British.}

The L. aculeatum which I found
LOCALITIES.

Pictou.

Pictou and South Joggins, Nova Scotia.

Sydney, Cape Breton.

Pictou, Nova Scotia.

Pictou, Nova Scotia; Sydney, Cape Breton.

Sydney, Cape Breton.

Pictou, Nova Scotia.

Cape Breton.

Sydney, Cape Breton. 
NAMES OF FOSSIL PLANTS. abundantly associated with this in the U. S. coal-fields appears to Mr. Woodward not specifically distinct from L. obovatum.

12. L. undulatum Sternberg. This species, also British, was found by Mr. Henwod in New Brunswick.

13. Lepidodendron elegans (Lindley and Hutton.)

Extremely common in the coalfields of Nova Scotia down to the lower or gypsiferous coal-measures.

14. L. gracile?

Also a British species.

15. L. (new species.)

Not known in Europe or elsewhere ; the specimen is in the $\mathrm{Mu}$ seum of the Geol. Society.

16. L. In the same fissured state as L. or natissimum, figured by Brongniart.

17. Lycopodites? selaginoides (Lepidodendron selaginoides Sternberg).

Common in the British and Bohemian coal-measures.

18. Lepidostrobus.

I met with no species myself in Nova Scotia, but Mr. Dawson has observed it associated as in Europe with Lepidodendron.

19. Sigillaria Saullii Brong. pl. 151.

A British species found at Manchester.
LOCALITIES.

Bathurst, New Brunswick.

Horton and Windsor, Nova Scotia ; Sydney, Cape Breton.

South Joggins, Nova Scotia; Cape Breton.

Cape Breton.

South Joggins, Nova Scotia.

Cape Breton.

Pictou, Nova Scotia.

Windsor, Nova Scotia;

Sydney, C. B. 
Chap. xxiv.

NAMES OF FOSSIL PLANTS.

20. S. allied to S. Schlotthermii Brong. pl. 152, fig. 4.

21. S. scutellata Brong. pl. 163, fig. 3.

Also British.

Qucre. Same as S. undulata of Sternberg, tab. 15.

22. Sigillaria reniformis Brong. pl. 142. Lindley \& $H$. pl. 57 and 71.

This British species I have obtained from Cape Breton in a decorticated state, and found it common, with its bark, at Frostburg in Maryland.

23. S. organum Lindley \& $\boldsymbol{H}$. Sydney, Cape Breton. t. 70. Syriogodendron? Brong.

A British species.

24. Lyginodendron.

1 found various fluted stems without scars in the lower coal formation near Windsor, and elsewhere in Nova Scotia. Perhaps these fossils may be only lower portions of the stems of Sigillariæ, in which the scars are obliterated by age and growth.

25. Stigmaria ficoides, and numerous varieties.

These seem to agree well with the different British kinds, probably the roots of distinct species of Sigillaria.

26. Neuropteris cordata, Brongn. pl. 64, f. 5. Lindley and Hutton, 41.

Extremely common in the middle

LOCALITIES.

South Joggins, Nova Scotia.

South Joggins, Nova Scotia.

Sydney, Cape Breton. 
Chap. xxiv. Nova scotia AND CAPE bReton.

NAMES OF FOSSIL PLANTS.

or productive coal-measures of Nova Scotia ; also British.

27. N. angustifolia, Brongn. t. 61, f. 3,4 .

Also British.

28. Neuropteris flexuosa Brongn. t. 65, f. 2.

The most abundant fern in the coal-measures of Nova Scotia, the U. S., and Europe. Also British.

29. N. acutifolia ? allied to Odontopteris minor Brongn. t. $7 \%$.

30. Cyclopteris dilatata? Lindley and Hutton. See Neuropteris ingens, t. 91, A.

Qucre, if variety of $\mathrm{N}$. cordata. The only indication of a Cyclopteris which I have met with in Nova Scotia. I found the same species at Pomeroy, Ohio.

31. Pecopteris muricata Brongn. pl. 95 \& 97.

Perfectly identical with common British specimens.

32. P. abbreviata Brongn. pl. 115.

Common British species.

33. P. arborescens Brongn. pl. 102.

Also British.

34. P. lonchitica Brongn. pl. 84.

The most characteristic British species of Pecopteris in the coalmeasures.
LOCALITIES.

Cape Breton.

Cape Breton.

Sydney, Cape Breton.

Sydney, Cape Breton.

South Joggins, and Dickson's Mill, Pictou ; also Bathurst, New Brunswick.

Cape Breton.

Cape Breton.

South Joggins, Nova Scutia. 
Chap. Xxiv.

NAMES OF FOSSIL PLANTS.

35. P. pteroides Brongn. pl. 99. f. 1 .

Also British.

36. Pecopteris æqualis Brongn. Also British.

37. $\mathrm{P}$.

A remarkable species, with anastomozing veins, resembling in this respect the $\mathrm{P}$. Defrancii of Brongniart. Mr. Charles Bunbury observes respecting this species, that "its venation is completely reticulated, the midrib evanescent," and "it would form the type of a new genus, standing in the same relation to Lonchopteris as Neuropteris does to Pecopteris."

38. P. Sillimanni ?. Brongn. pl. 96, f. 5 .

A single pinna, collected by $\mathrm{Mr}$. Henwood.

39. P. villosa Brongn. pl. 104, f. 3.

Also British.

40. P. Serlii Brongn. pl. 85. Also British.

Calamites.

The specimens of this genus scarcely afford satisfactory specific characters to the botanist, but all the Nova Scotia fossils agree with common European forms from the coal-measures.

41. C. cannæformis Schlot.

42. C. Suckowii Brongn.
LOCALTTIES.

Bathurst, New Brunswick.

Cape Breton.

Sydney, Cape Breton.

Bathurst, New Brunswick.

Dickson's Mill, Nova Scotia.

Sydney, Cape Breton.

South Joggins, Nova Scotia, and Cape Breton.

South Joggins, Nova Scotia, 
Chap. xxiv. Nova scotia ANd CAPE bReton.

NAMES OF FOSSIL PLANTS.

43. C. approximatus Artis.

44. C. arenaceus? Jager.

45. C. Steinhaueri Brongn.

46. C. dubbius Brongn.

47. C. nodosus Schlot.

48. C. Cistii Brongn. Also British.
LOCALITIES.

Cape Breton, Nova Scotia.

Nova Scotia.

South Joggins, Nova Scotia.

Sydney, Cape Breton. Pictou, and South Joggins, Nova Scotia.

Sydney, Cape Breton. 


\section{CHAPTER XXV.}

Lower Carboniferous or Gypsiferous Formation of Nova Scotia. -Why formerly considered as newer than the productive Coal.-Determination of its true Age.-Sections nearWindsor. -Supposed Reptilian Footsteps.-Section on the Shubenacadie.-Large Masses of Gypsum.-Their Origin.-Volcanic Action contemporaneous with Nova Scotia Coal Measures.Limestone with Marine Shells.-Table of Organic Remains of the Carboniferous Limestone of Nova Scotia and Island of Cape Breton.

The productive coal-measures near Minudie, described in the last chapter, may be regarded as the middle of the carboniferous series of Nova Scotia; while the strata above them, including the beds with Modiola, $h, i$ (fig. 19, p. 151), and the sandstones and shales farther to the south, in the same region, together with a corresponding series near Pictou, and the lower sandstone of Prince Edward's Island, ascertained by Mr. Dawson to contain coal-plants, may be all classed as the Upper Carboniferous division, in which no seams of coal have yet been found. Lastly, we may regard an enormous mass of red and brown sandstones and red marls, the lower portions of which include beds of gypsum, and limestones charged with marine shells and corals, as the Lower Carboniferous or gypsiferous series. In this division grits and shales, with some true coal plants and some thin seams of impure coal are occasionally met with.

Before my visit to Nova Scotia, the group last mentioned had been considered, chiefly, I believe, 
Chap. Xxv.

from its resemblance to the gypsiferous red marls above the coal in Europe, as the uppermost formation in Nova Scotia. Mr. Logan, in his first brief excursion in 1841 to the Windsor district, where the beds are greatly disturbed, had little more than time to collect some of the most abundant fossils; and these, when submitted to several able palæontologists (to M. de Verneuil among others), were thought to confirm the opinion previously entertained, that the strata were newer than the coal. That geologists should at first have arrived at this result will surprise no one who is aware how many of the fossils of our Magnesian limestone and coal resemble each other, or who studies the list given at p. 218, in which several species both of shells and corals from Nova Scotia, identical or closely allied to well-known Permian or Magnesian limestone forms, are enumerated. By these considerations my friend Mr. Murchison was induced, in his Anniversary Address to the Geological Society of London, in $\mathbf{1 8 4 3}$, to pronounce the gypsiferous rocks of Nova Scotia as the equivalents in age of the Permian group of Russia. My first inspection of the country near Windsor, followed by an examination of the cliffs near Minudie, described in the last Chapter, led me to an opposite view, strengthened by discussions with Mr. Richard Brown of Sydney, and Mr. J. W. Dawson of Pictou, with whom I explored the cliffs of the East River, south of the Albion Mines, near Pictou. I then examined with care, in company with Messrs. Dawson and Duncan, the fine section laid open in the cliffs of the Shubenacadie, a river which intersects Nova Scotia from south to north, cutting through the gypsiferous strata for a 
distance of twenty miles. Lastly, I had an opportunity of studying at my leisure in London the fossils collected from various localities, and I had then no longer any hesitation in announcing to the Geological Society my conviction, that the gypsiferous strata were older than the productive coal-measures, whether of the South Joggins or of Pictou. I also stated at the same time my opinion that I considered them as constituting a lower member of the Carboniferous group, containing fossil plants of the coal, with shells and corals of the carboniferous limestone.

Mr. Richard Brown, after our meeting at the Albion Mines in 1842 , kindly undertook, at my request, to make a re-examination of part of Cape Breton, and the result was published in a letter, dated October 20, 1843 , addressed to me,* in which this experienced observer declared that he had been able " to confirm my views as to the relative age of the coal and gypsum," and that the gypsiferous strata of Cape Breton, agreeing in character with those of Nova Scotia, were inferior in position to the productive coal-measures of Sydney. Mr. Dawson also, soon after my visit, published several memoirs on the neighbourhood of Pictou and the northern parts of Nova Scotia, in which he adopted and extended the same views. Mr. Logan, after seeing my fossils and sections, and examining in 1844 the cliffs near Minudie, and at the South Joggins, which he had not seen on his first visit to Nova Scotia, communicated to me his opinion that the gypsum and accompanying marine limestones (in which he found several of the characteristic fossils of

* See "Quarterly Journal of the Geological Society of London," No. I., p. 23. 
Windsor), and the red sandstones near Minudie, were older than the productive coal-measures. Dr. Gesner, however, has not abandoned the opinion at which he had previously arrived on this point, having recently, in a letter addressed to the President of the Geological Society, and read May, 1845, declared his belief that the true order of superposition is not as I have represented it, and that other geologists have been misled by me.

As this question affects the geological structure of a large portion of Nova Scotia, I shall give a brief outline of the data which favour the classification I have proposed. In the first place, I found everywhere that the gypsiferous formations were much more disturbed than those strata which I have called the Middle and Upper coal-measures, and that their outcrop was always nearer to the region occupied by the older rocks, whether Silurian or Metamorphic. Thus, for example, if we pass from the granitic mountains and older slates of the Cobequid Hills to the coal of the South Joggins, we find the gypsum and limestone nearest the Hills : or, if we descend the East River, we pass from the Silurian strata, cross the region in which limestones and gypsums occur, and then come to the coal-measures of the Albion Mines. Mr. Richard Brown has shown, in the Memoir above cited, that the same arrangement holds good in Cape Breton. Secondly, the regular dip of all the beds seen near Minudie (see section above, p. 151) would carry the strata to which the limestone and gypsum are subordinate under the workable coal of the South Joggins. Thirdly, geologists before and since my visit, who have carefully examined the East 
River, south of Pictou, including Mr. Logan, are agreed that the sandstones and marine limestones, some of them having an oolitic structure, occurring to the south of the Albion Mines, are older than the coal of those mines. Now I found that most of the fossils of those limestones agreed with shells and corals obtained by me in the limestones near Windsor, or in those of the Shubenacadie, accompanying the principal masses of gypsum. Fourthly, both in the Windsor district, and on the Shubenacadie, I found an intimate association between strata containing mountain limestone fossils, masses of gypsum, and coal grits, with Sigillaria and Lepidodendron, but no seams of pure coal in this part of the series. Fifthly, I observed that, in the Pictou region, as well as at the South Joggins, the strata which I class with Mr. Dawson as the Upper coal-measures, although several thousand feet thick, and respecting the position of which above the productive coal there is no question, contain no marine limestones, or great masses of gypsum. Sixthly, there is a formation of unconformable red sandstone without fossils, which appears on the Salmon River six miles above Truro, lying on the edges of the inclined Carboniferous strata. In this series of beds no limestone with marine shells or gypsum have been discovered.

In illustration of the first of these points, namely, that the gypsiferous rocks occur nearest to the older formations, I may cite, in addition to the Minudie and East River sections already adverted to, the structure of the first country which I observed near Windsor. I saw, for example, the gypsum near the Halifax Road almost in contact with the old slates of the Ardoise 
Hills, and afterwards traced the gypsiferous beds of the Saint Croix River up to their junction with the older slates. I also found, in going southwards from Windsor to a small tributary of the Avon, on which is situated Snides Mill, that the gypsiferous series incloses, before its junction with the older rocks, coarse sandstones with a seam of impure coal two inches thick, also clay-iron-stone, and shales with Lepidodendron elegans, but no strata resembling the pro ductive coal-measures.

I consider the inclined and bent rocks near the town of Windsor, consisting of soft red, yellow, and purple marls, with conformable beds of limestone and gypsum, as higher in the series than the coal-grits above mentioned. In some of these limestones of Windsor, one of which having an oolitic texture occurs near the bridge, and another on the farm of Belvidere on the Avon, the following fossils occur, Terebratula suffata, T. elongata, two other species of Terebratula, Producta Martini, P. Lyelli (De Verneuil) Pecten plicatus, Avicula, Modiola, allied to $\boldsymbol{M}$. Pallasi, Cirrus spiralis, Euomphalus lavis, Natica, Fenestella membranacea, and Ceriopora spongites, almost all of which I afterwards found on the Shubenacadie, and some of them on the Debert River near Truro, associated with gypsum, also in strata on the East River, decidedly lower than the productive coalmeasures.

I consider the highly-inclined and curved strata of Horton Bluff, near Windsor, as affording another fine section of the Lower Carboniferous series associated with the gypsum. In the cliffs here I found Lepidodendra, and other coal plants, and scales of fish of the 
genera Holoptichius and Paleoniscus, both of them common to the English coal-measures. Mr. Logan detected in the same strata masses of concretionary limestone, which I had overlooked, and which are interesting, as they contain the Terebratula elongata, Avicula, and other marine fossils identical with those of Windsor. He also found, in one of the ripplemarked slabs of Horton what appear to be the impressions of the footsteps of an animal, perhaps a Reptilian, having five claws. There are two of these tracks, and they resemble considerably some footprints in the New Red sandstone of England, but, as they are on a stratum containing fucoids, and are not very sharp in their outline, like tracks formed above water, and as there is no series of them, Mr. Owen does not feel himself entitled to decide positively on their reptilian character.* $\mathrm{Mr}$. Dawson has also found impressions resembling trifid footsteps in several parts of the carboniferous series of Nova Scotia, in ripple-marked sandstones, so sharp as to imply that they were not made above water; but I have not yet been able to decide that any of them belong to vertebrate animals.

The gypsiferous strata are best disclosed in the cliffs which bound the estuary of the Shubenacadie, for a distance of about 14 miles from north to south, or between Fort Ellis and the mouth of the river, where they are several thousand feet in thickness.

* Dr. A. King has lately published an account in the Proceedings of the Academy of Natural Science of Philadelphia, Nov., 1844, of footsteps, referable, some of them to birds, others to batrachian reptiles, from the true carboniferous strata of Westmoreland county, Pennsylvania._Sillima'n's Journal, vol. xlviii, p. 343, 1845. 
The rapid tides of the Bay of Fundy continually undermine and sweep away the fallen detritus at the base of these cliffs, otherwise the section would soon be obscured, so rapid is the disintegration of the soft red marls, with which the gypsum and fossiliferous limestones are interstratified. The general strike of the beds on the Shubenacadie, as at Windsor, is nearly east and west, the strata seeming to have been first folded into numerous parallel wrinkles, running east and west, and then part of these folds tilted at considerable angles, sometimes towards the east, and sometimes to the west, while the rocks were fissured in the direction of their strike, and shifted vertically. By such complicated movements the strata have been thrown into the greatest confusion. At the Big Rock, a mass of gypsum or alabaster of a pure white colour and no less than $\mathbf{3 0 0}$ yards thick, is exposed and forms a conspicuous object in the vertical cliff, and has been followed continuously east and west for 12 miles through the country. Below it are alternations of anhydrous gypsum with yellow shale and bituminous limestone. Among the dislocated strata which alternate with the gypsiferous series, are three masses consisting of coal-grit, shale with lepidodendra, and red sandstone, which I refer to the same formation. In five cases where Mr. Dawson and I traced the junction of these sandstones with the gypsiferous beds, visible only at low water, we found a line of fault at the point of contact, and one wall of the fault was in every case formed of gypsum : yet I do not believe that the gypsum has filled rents, for it has all the appearance of having been an original and intregral part of the stratified series, formed 
contemporaneously with the beds of red marl and marine limestone. If we endeavour to account for the origin of the gypsum by the subsequent conversion of carbonate into sulphate of lime, we encounter this difficulty, that beds of limestone full of fossils are intimately associated with the gypsum, and yet have undergone no alteration. I saw nowhere any passage from the one to the other even at points where the gypsum and limestone alternate. On the other hand, there are abundant proofs in various parts of Nova Scotia of the intrusion of trappean rocks of contemporaneous origin with the lower carboniferous strata, so that I have little doubt that the production of gypsum in the carboniferous sea was intimately connected with volcanic action, whether in the form of heated vapours (or stufas), or of hot mineral springs, or any other kind of agency accompanying submarine igneous eruptions. To the influence of these latter I also ascribe the remarkable mineralogical difference between the inferior carboniferous rocks of Nova Scotia and those of the coal-fields of the United States, which are free from trappean rocks.

The gypsum of Nova Scotia when burnt is used for manure, and is shipped in great quantities for the United States. There are many indications of metalliferous ores in the rocks of the Shubenacadie, and the neighbouring districts, and among other places, I observed near the mouth of the river and on its left bank, a limestone called the Black Rock, containing disseminated crystals of galena with one of magnesia, copper, lead and cobalt.

The limestones containing marine shells on the Shubenacadie occur, 1st, at a place north of Rose's 
Point, about $7 \frac{1}{2}$ miles above the mouth of the river ; 2dly, at the point called Anthony's Nose, nearly opposite, in both places near beds of gypsum ; 3dly, at Admiral's rock, four miles higher up the river, on its left or western bank. One dark bed in the latter locality is made up entirely of the broken stems of a small species of encrinus. Some layers at Anthony's Nose are almost exclusively composed of a small coral, Ceriopora spongites, Goldf., while in other beds Productæ are very abundant. The greater number of species are common to the different limestones of the Shubenacadie, the district round Windsor and that of Brookfield, a locality eight or nine miles to the east of Anthony's Nose, and probably in the strike of that fossiliferous rock. For a set of fossils from the place last mentioned, enumerated in the list at page 183, I was indebted to Mr. Duncan, of Truro. The limestone of Gay's River, having many shells in common with the above-mentioned rocks, occurs near the outcrop of the gypsiferous formation, eight miles south of Fort Ellis, where the Shubenacadie section above alluded to terminates, and near which older formations make their appearance.

In addition to the places above-mentioned, I also discovered during my tour with $\mathrm{Mr}$. Dawson, to whose active operations I was much indebted, a series of strata below the bridge on the Debert River, thirteen miles east of Truro, consisting of highly-inclined beds of red limestone and black slaty limestone, red sandstone, and red marl, in which a large number of the Windsor shells occurred, together with some small bivalves, and a fragment of a Limulus, or a genus intermediate between Limulus and Trilobite,

VOL. II. 
resembling that of the coal-measures of Colebrook Dale, figured by Mr. Prestwich. We also saw beds similar to the above in the district of Onslow, about twelve miles N. E. of the Debert River bridge, where there is also a black slaty limestone, with similar small bivalve shells in it.

The annexed Table will show in one view the fossils of the various lucalities of the gypsiferous limestone of Nova Scotia, together with a few others from Cape Breton, decidedly of the same formation, which I received from $\mathrm{Mr}$. Richard Brown and $\mathrm{Mr}$. James Dawson. Mention is made in the Table of the geological position, when known, of the same species in other countries. I am indebted to M. de Verneuil for the determination of the greater part of the shells. On considering this Table we shall not hesitate to pronounce the gypsiferous formation of Nova Scotia to be a member of the carboniferous group, instead of the triassic or magnesian limestone formation, to both of which it had been severally conjectured to belong. The presence of the genera Orthoceras, represented by two species, the Nautilus and Conularia, the Limulus or Trilobite, and the Cyathophyllum are opposed to the opinion that the beds are newer than the coal. The following species are either identical or scarcely distinguishable from well known mountain limestone fossils; Enomphalus lævis, Pileopsis vetustus, Pecten plicatus, Isocardia unioniformis, Phil. Producta Martini, P. Scotica? The Ceriopora spongites also occurs in the mountain limestone in Ireland; and the coral which has been compared to Retepora flustracea of the magnesian limestone is not the same, but more 
nearly allied to, if not identical with Fenestella membranacea of the mountain limestone, according to Mr. E. Forbes. The abundance of this coral and three shells, namely, Terebratula elongata, Modiola allied to M. Pallasi, and Avicula antiqua, brought by Mr. Logan from Windsor, first led to the presumption that the gypsiferous beds were newer than coal; but $M$. de Verneuil now informs me that T. elongata has also been found in the mountain limestone of Yorkshire. The other genera mentioned in the Table accord well with the Carboniferous fuana, a result which we might expect from the association before mentioned of the Gypsiferous marine Limestone with sandstone and shales, containing Lepidodendron elegans. It will be seen that the agreement of species from various and often distant localities is quite as great as could have been expected, when we consider the small number of the fossils hitherto obtained.

LIST OF FOSSILS OF THE LOWER CARBONIFEROUS OR GYPSIFEROUS FORMATION OF NOVA SCOTIA AND CAPE BRETON.

NAMES OF FOSSILS.

1. Trilobite or Limulus.

2. Cypris or Cytherina.

3. C - Second species.

4. Nautilus. Allied to N. Leplayi, Demidoff;
LOCALITIES.

Debert River, near teir Truro.

South Joggins and Pictou, Nova Scotia.

South Joggins.

Brookfield, Nova Scotia. 
NAME OF FOssIus.

and to N. bidorsatus., Fischer. (Oryctol. of Warsaw.) A fossil of the Mountain Limestone of Europe.

5. Cyrtoceras.

A genus not known above the coal.

6. Orthoceras.

Analogous to O. Gesneri, Martin, with longitudinal striæ, and with the syphon between the centre and the border.

\section{7. $\mathrm{O}$}

Second species. Larger and different, but specimens imperfect.

8. Conularia.

New species, distinct from C. quadrisculatê, by size, distance of striæ, and other characters.

9. Littorina?

Analogous to a Permian species.

10. Cirrus spiralis (or C. rotundatus ?)

11. Enomphalus lævis.

$\Lambda$ fossil also of the Devonian and Carboniferous formations of the Eiffel.

12. Natica.

New species, like N. plicistria, but smaller; found also by $\mathrm{De}$ Verneuil in the Permian rocks of Russia.

13. Cypricardia.

New species, (aff. C. transversa) fossil in the mountain limestone of Belgium.
LOC ALITIES.

Windsor, Nova Scotia.

Brookfield.

Windsor.

Brookfield, and Gut of Canso, Cape Breton.

Gay's River.

Windsor.

Windsor.

Windsor and Gay's River, Nova Scotia.

Windsor. 
Chap. xxv. mountain limestone, nova scotia. 185

NAME OF FOSSILS.

14. Isocardia unioniformis Phil. A shell of the carboniferous limestone.

15. Cardiomorpha Archiacana. Found in the coal of Belgium.

16. Bivalve.

Numerous impressions, genus not determinable, common to several localities.

17. Cucullæa.

New species (aff. C. obtusa Phil.)

18. Modiola (afl: M. Pallasi).

Like one in Permian formation of Russia.

19. M. A second species.

20. Avicula antiqua Munst.

In Zechstein of Europe.

21. A

New species allied to the preceding, but more gibbous.

22. $\mathrm{A} \longrightarrow$.

With forty-five narrow ribs.

23. $\mathrm{A}-$

$24 \& 25$. A.

Two other species.

26. Pecten plicatus.

Or very analogous.

27. P — (or Avicula).

Smooth.

28. $\mathrm{P}-$.

New species.
LOCALITIES.

Brookfield.

Windsor.

Debert River and Onslow District, Nova Scotia.

Windsor.

Windsor, Brookfield, and Gay's River.

Gay's River.

The Shubenacadie and Gay's River.

Gay's River.

Debert River.

Debert River.

Windsor.

Windsor, Brookfield, and Shubenacadie.

Debert River.

Brookfield. 
Chap. xxv.

NAME OF FOSSILS.

29. $\mathrm{P}$

New species, allied to P. granosus, found in the carboniferous limestone.

30. Terebratula elongata Schlot.

Occurs in the Zechstein in Europe, and in the mountain limestone of Yorkshire.

31. T. sufflata.

Quare. Gibbous variety of preceding, De Verneuil.

32. $\mathrm{T} \longrightarrow$.

Small, like T. diodonta with sinus.

33. $\mathrm{T}$

With one fold in the sinus.

34. $\mathrm{T}$

New Species.

35. Terebratula.

New species, with sinus reaching very nearly to the beak, very like one described by Von Buch, as T. canidea.

36. Spirifer glaber.

Fossil of mountain limestone and Zechstein of Europe.

37. S. cristatus ?

Fossil of English magnesian limestone.

38. S. Minimus Sow.

Or new species? A fossil of the Permian of Russia.

39. S. octoplicatus. Silurian of Europe?
LOCALITIES.

Shubenacadie.

Windsor, Brookfield, Shubenacadie, Gay's River, Debert River, and Cape Breton.

Windsor, Brookfield, Shubenacadie, and Debert River.

Debert River.

Windsor and Shubenacadie.

Windsor.

Brookfield.

East River of Pictou, and Cape Breton.

Windsor.

Windsor, Brookfield, Shubenacadie, and Debert River.

Windsor. 
Chap. xxv. Mountain LIMestone, nova scotia. 187

NAMES OF FOSSILS.

40. Producta Martini.

A fossil of the mountain limestone of Europe.

41. P. concinna, Sow.

Or allied Species ; carboniferous limestone of Europe.

42. P. Lyelli, De Verneuil.

Shell with fine striæ, and with long and slender tubes, the most characteristic fossil of the lower carboniferous formation.

43. Producta Scotica.

Smaller than European, if identical ; carboniferous limestone, Europe.

44. P. Spinosa Sow.

Qucre. Var. of P. Martini. Carboniferous limestone, Europe.

45. P. antiquata de Koninck.

Coal-measures, Europe.

46. Encrinus.

47. Fenestella membranacea ? (Retepora membranacea, Phil.)

Carboniferous limestone, Europe.

48. Ceriopa spongites, Goldfuss. (pl. 64.)

Eiffel, Silurian, and mountain limestone, Ireland.

49. Favosites ramosa?

50. Cyathophyllum.
LOCALITIES.

Windsor, Brookfield, Shubenacadie, East River of Pictou, and Cape Breton.

Cape Breton.

Windsor, Horton Bluff, Shubenacadie, Gay's River, Debert River, Minudie, and Cape Breton.

Windsor, Brookfield, Shubenacadie, East River of Pictou, and Cape Breton.

Cape Breton.

Brookfield.

Shubenacadie, and East River, Pictou. Windsor, Brookfield, the Shubenacadie, and East River, Pictou.

Windsor and Brookfield.

Shubenacadie.

Cape Breton. 


\section{CHAPTER XXVI.}

Progress and Resources of Nova Scotia.-Highland Settlers.Timber Duties.-Cobequid Hills.-Conflagration of Forests.Albion Mines.-Humming Birds._Estuary of the Shubenacadie.-Stakes cut by Beavers.-Promotion of Science.Social Equality.-Nova Scotians "going home."-Return to England.

The day after my arrival in Nova Scotia, a fellowpassenger in the coach from Halifax to Windsor, a native of the country, and who, from small beginnings, had acquired a large fortune, bore testimony to the rapid strides which the province had made, within his recollection, by deploring the universal increase of luxury. He spoke of the superior simplicity of manners in his younger days, when the wives and daughters of farmers were accustomed to ride to church, each on horseback behind their husbands and fathers, whereas now they were not content unless they could ride there in their own carriage.

In spite of the large extent of barren and siliceous soil in the south, and, what is a more serious evil, those seven or eight months of frost and snow which crowd the labours of the agriculturist into so brief a season, the resources of this province are extremely great. They have magnificent harbours and fine navigable estuaries, large areas of the richest soil gained from the sea, vast supplies of coal and gypsum, and abundance of timber. 
Not a few of the most intelligent and thriving inhabitants are descended from loyalists, who fled from the United States at the time of the declaration of independence. The picture they drew of the stationary condition, want of cleanly habits, and ignorance of some of the Highland settlers, in parts of Nova Scotia and Cápe Breton, was discouraging, and often so highly coloured as to be very amusing. They were described to me as cropping the newly cleared ground year after year without manuring it, till the dung of their horses and cattle accumulated round their doors, and became, even to them, an intolerable nuisance. They accordingly pulled down their log-cabins and removed them to a distance, till several of their more knowing neighbours offered to cart away the dung for a small remuneration. After a time, when the Highlanders perceived the use to which the manure was put, they required those who removed it to execute the task gratuitously; and my informants thought that the idea might possibly occur to some of the next generation of applying the material to their own fields.

I heard frequent discussions on the present state of the timber duties both here and in Canada, and great was my surprise to find the majority of the small proprietors, or that class in whose prosperity and success the strength of a new colony consists, regretting that the mother country had legislated so much in their favour. They said that a few large capitalists and shipowners amassed considerable fortunes (some of them, however, losing them again by over-speculation), and that the political influence of a few such merchants was naturally greater than that of 
a host of small farmers, who could never so effectively plead their cause to the Government. But, on the other hand, the labourers engaged during the severe winter, at high pay, to fell and transport the timber to the coast, became invariably a drunken and improvident set. Another serious mischief accrued to the colony from this traffic: as often as the new settlers reached the tracts from which the wood had been removed, they found, instead of a cleared region, ready for cultivation, a dense copsewood or vigorous undergrowth of young. trees, far more expensive to deal with than the original forest, and, what was worse, all the best kinds of timber, fit for farm buildings and other uses, had been taken away, having been carefully selected for exportation to Great Britain. So that, while the English are submitting to pay an enhanced price for timber inferior in quality to that of Norway, the majority of the colonists, for whom the sacrifices are made, feel no gratitude for the boon. On the contrary, they complain of a monopoly that enriches a few timber merchants, at the expense of the more regular and steady progress of agriculture. After my visit to the district of Windsor, Cape Blomidon, and Minudie, I went by Amherst to the Cobequid Hills, the nucleus of which consists of granite. Their outline, though rounded and not picturesque, formed a striking contrast to that of the low, long, flat-topped and uniform ridges, with straight intervening valleys, into which the Cumberland coalfield near Minudie is divided. On the highest part of the Cobequid Hills, we crossed a fine wild forest covering the granite, and then, on the southern flanks of those hills, I observed clay-slate cut through by 
trap dikes. We then went by Londonderry to Truro at the head of the Bay of Fundy, and from thence took places for Pictou in an open four-wheeled vehicle, here termed a wagon, which carried the mail. The road was cut through an endless forest of fir-wood, parts of which had lately suffered much by conflagrations. These fires often spread for leagues in the summer season, and cause great devastation. The more resinous species of fir, when they have been heated by the burning of the surrounding timber, blaze up suddenly when the fire at last reaches them, and are enveloped from top to bottom in brilliant flames, presenting in the night a most splendid spectacle.

I had arranged with Captain Bayfield, whom I had not seen for many years, that we should meet at Pictou, and the day after my arrival there, his surveying ship, the Gulnare, sailed into the harbour. I spent a day on board that vessel, and we then visited together the Albion Mines, from whence coal is conveyed by a railway to the estuary of the East River, and there shipped. Mr. Richard Brown, whose able co-operation in my geological inquiries I have before acknowledged, had come from Cape Breton to meet me, and with him and Mr. Dawson I examined the cliffs of the East River, accompanied by the superintendent of the Albion Mines, Mr. Poole, at whose house we were most kindly received. Here, during a week of intense heat, in the beginning of August (1842), I was frequently amused by watching the humming-birds, being able to approach unperceived, by aid of a Venetian blind, to within a few inches of them, while they were on the wing. They remained for many 
seconds poised in the air, while sucking the flowers of several climbers trailed to the wall on the outside of the window, and in this position the head and body appeared motionless, brilliant with green and gold plumage, and the wings invisible, owing to the rapidity of their motion. The sound was somewhat like that of our humming hawk-moths or sphinges, but louder. When they darted away, they seemed to emit a flash of bright colour. Following them into the garden, I sometimes saw them perched upon the dry stakes on which peas were trained, and there plume themselves. It is wonderful to reflect on the migrating instinct which leads these minute creatures from the distant Gulf of Florida to a country buried constantly under deep snow for seven or eight months in the year.

After leaving Pictou, I made an expedition with Mr. Dawson to the Shubenacadie (see above, p. 139), and at Truro we were joined by Mr. Duncan, by whose advice we started at an early hour each morning in a boat, after the great tidal wave or bore had swept up the estuary, and were then carried ten, fifteen, or twenty miles with great rapidity up the river, after which as the tide ebbed, we came down at our leisure, landing quietly wherever we pleased, at various points where the perpendicular cliffs offered sections on the right or left bank.

On one occasion, when I was seated on the trunk of a fallen tree, on a steep sloping beach about ten feet above the level of the river, I was warned by my companion that, before I had finished my sketch, the tide might float off me and the tree, and carry both down to the Basin of Mines. Being incredulous, I 
looked at my watch, and observed that the water remained nearly stationary for the first three minutes, and then, in the next ten, rose about three feet, after which it gained very steadily but more slowly, till I was obliged to decamp. A stranger, when he is looking for shells on the beach at low tide, after the hot sun has nearly dried up the sandy mud, may well be surprised if told that in six hours there will be a perpendicular column of salt water sixty feet high over the spot on which he stands.

The proprietor of one of the large quarries of gypsum on the Shubenacadie showed me some wooden stakes, dug up a few days before by one of his labourers from a considerable depth in a peat bog. His men were persuaded that they were artificially cut by a tool, and were the relics of aboriginal Indians; but having been a trapper of beavers in his younger days, he knew well that they owed their shape to the teeth of these creatures. We meet with the skulls and bones of beavers in the fens of Cambridgeshire, and elsewhere in England. May not some of the old tales of artificially cut wood occurring at great depths in peat and morasses, which have puzzled many a learned antiquary, admit of the like explanation?

I never travelled in any country where iny scientific pursuits seemed to be better understood, or were more zealously forwarded, than in Nova Scotia, although I went there almost without letters of introduction. At Truro, having occasion to go over a great deal of ground in different directions, on two successive days, I had employed two pair of horses, one in the morning, and the other in the afternoon, The vOL. II. 
postmaster, an entire stranger to me, declined to receive payment for them, although I pressed him to do so, saying that he heard I was exploring the country at my own expense, and he wished to contribute his share towards scientific investigations undertaken for the public good.

We know, on the authority of the author of "Sam Slick," unless he has belied his countrymen, that some of the Blue Noses (so called from a kind of potato which thrives here) are not in the habit of setting a very high value, either an their own time or that of others. To this class, I presume, belonged the driver of a stage-coach, who conducted us from Pictou to Truro. Drawing in the reins of his four horses, he informed us that there were a great many wild raspberries by the road-side, quite ripe, and that he intended to get off and eat some of them, as there was time to spare, for he should still arrive in Truro by the appointed hour. It is needless to say that all turned out, as there was no alternative but to wait in the inside of a hot coach, or to pick fruit in the shade. Had the same adventure happened to a traveller in the United States, it might have furnished a good text to one inclined to descant on the inconvenient independence of manners which democratic institutions have a tendency to create. Doubtless, the political and social circumstances of all new colonies promote a degree of equality which influences the manners of the people. There is here no hereditary aristocracy -no proprietors who can let their lands to tenantsno dominant sect, with the privileges enjoyed by a church establishment. The sects are too numerous, and too fairly balanced, to admit of the possibility of 
such a policy; and the Baptists, who predominate greatly in number and position in society, are opposed on principle to all ecclesiastical endowments by the State. The influence of birth and family is scarcely felt, and the resemblance of the political and social state of things to that in the United States is striking.

The longer, indeed, that I remained here, the larger were the deductions I found it necessary to make from those peculiarities that I had imagined, during my sojourn in the United States, to be the genuine fruits of a republican as contrasted with a monarchical constitution, - of an American as distinguished from a British supremacy. They who lament the increased power recently acquired by the democracy in the United States, ascribe to it, and I believe not without reason, the frequent neglect of men of the greatest talent and moral worth, and the power which it gives to envy, concealing itself under the cloak of a love of equality, to exclude such citizens from the most important places of trust and honour. In our American colonies, on the other hand, we hear complaints that very similar effects result from the habitual disregard of the claims of native merit, all posts of high rank and profit being awarded to foreigners, who have not their hearts in a country where they are but temporary sojourners. The late revolution in our colonial system, obliging the responsible executive to command a majority in the colonial parliaments, must, it is to be hoped, remove this cause of dissatisfaction.

It is no small object of ambition for a Nova Scotian to "go home," which means to "leave home, 
and see England." However much his curiosity may be gratified by the tour, his vanity, as I learn from several confessions made to me, is often put to a severe trial. It is mortifying to be asked in what part of the world Nova Scotia is situated-to be complimented on "speaking good English, although an American"-to be asked "what excuse can possibly be made for repudiation"-to be forced to explain to one fellow countryman after another "that Nova Scotia is not one of the United States, but a British province." All this, too, after having prayed loyally every Sunday for Queen Victoria and the Prince of Wales-after having been so ready to go to war about the Canadian borderers, the New York sympathisers, the detention of Macleod and any other feud!

Nations know nothing of one another-most true -but unfortunately in this particular case the ignorance is all on one side, for almost every native of Nova Scotia knows and thinks a great deal about England. It may, however, console the Nova Scotian to reflect, that there are districts in the British isles, far more populous than all his native peninsula, which the majority of the English people have never heard of, and respecting which, if they were named, few could say whether they spoke Gaelic, Welsh, or Irish, or what form of religion the greater part of them professed.

August 18.-We left Halifax in the steamship Columbia, and in nine days and sixteen hours were at the pier at Liverpool. This was the ninetieth voyage of these Halifax steamers across the Atlantic, without any loss, and only one case of detention by 
putting back for repairs. As we flew along in the railway carriage between Liverpool and London, my eye, so long accustomed to the American landscape, was struck with the dressy and garden-like appearance of all the fields, the absence of weeds, and the neatness of the trim hedgerows. We passed only one unoccupied piece of ground, and it was covered with heath, then in full blossom, a plant which we had not seen from the time we crossed the Atlantic. Eight hours conveyed us from sea to sea, from the estuary of the Mersey to that stream which Pope has styled "the Father of the British Floods." Whatever new standard for measuring the comparative size of rivers I had acquired in my late wanderings, I certainly never beheld "the swelling waters and alternate tides" of Father Thames with greater admiration than after this long absence, or was ever more delighted to find myself once more in the midst of the flourishing settlement which has grown up upon his banks. 


\section{DESCRIPTI0N}

\section{OF \\ PLATES AND MAPS.}

\section{Plate I.}

Bird's-eye view of the Falls of Niagara and adjacent country, coloured geologically.

Frontispiece of Vol. I.

I HAve stated in the second chapter, Vol. I., that Mr. Bakewell, Jun., son of the distinguished geologist of that name, gave me his original coloured sketches of the Niagara district in 1841. He had previously published an outline of them in some wood-cuts in "Loudon's Magazine" for 1830, at a time when the geological structure of the country had not been worked out as it has since been by the State surveyors of New York. When I visited the Falls of Niagara in 1841, I conceived the idea of combining Mr. Bakewell's pictorial view with a correct geological representation of the rocks as determined by $\mathrm{Mr}$. Hall, who accompanied me to the Falls. A copy of the view thus made I sent off in the same year to the Geological Society, and exhibited another in illustration of a lecture delivered at Boston in the autumn. 
A reference to the section at p. 45 , Vol. I., and to map, Pl. III., and to the observations made at pp. 78 and 80, Vol. II., will enable the reader to understand the details exhibited in this view. The numbers on the right-hand margin from 1 to 6 correspond with those referring to similar colours in the map of the Niagara district, Pl. III., Vol. I. p. 30, in which the usual position of North and South have been reversed, that it might correspond with the bird's-eye view. In the latter, Lake Erie is seen in the distance, or to the South, and the river Niagara flowing out of it. This river at its exit is about 330 feet above Lake Ontario, and has a fall of about one foot in a mile for the first fifteen miles, until, after passing the larger or Grand Island, and approaching Goat Island, it descends rapidly about fifty feet in less than a mile, and is then thrown down about 165 feet perpendicularly at the Falls. For the dimensions of these and the ravine, see Vol. I., p. 31. The river then flows for seven miles in the ravine, with a fall of 100 feet. The first notch on the left bank marks the western side of the whirlpool, where the drift occurs, described in Vol. II., p. 78, as connected with the valley of St. David's. The next notch and projection, half a mile lower down on the opposite bank, marks the site of the Devil's Hole (see map, Pl. III.) where the Bloody Run enters. I have speculated upon this indentation, p. 42, Vol. I., as a spot where there are clear signs of the great cataract having been once situated. About four miles still lower down, the platform terminates suddenly in the escarpment, at the base of which are seen the towns of Lewiston and Queenstown, standing on the Medina sandstone, 
No. 6, which forms the low ground extending for about seven miles to Lake Ontario, as shown in the map Pl. III., the river having a fall of only four feet from Queenstown to its entrance into that lake.

The site of the town of St. David's is seen on the right-hand side of the bird's-eye view, and I have stated, at p. 80, Vol. II., that the opening here is represented, for want of more space, as of small width, but it is in fact nearly two miles broad at its mouth, forming a strong contrast to the narrowness of the ravine (about $\mathbf{4 0 0}$ yards wide) from which the Niagara escapes at Queenstown. This remarkable difference is doubtless connected with the entirely distinct mode of origin which $I$ have ascribed to the two openings, that of the Niagara having been formed by the excavating power of the river as it receded, that of St. David's by the antecedent denu. ding action of the waves of the sea during the upheaval of the land.

The two chapters to which this bird's-eye view principally refers are Ch. 2, Vol. I., and Ch. 19, Vol. II.

\section{Plate II.}

Geological Map of the United States, Canada, \&c., compiled from the State Surveys of the $U$. S., and other sources

Frontispiece of Vol. II.

The route which I followed through the United States and Canada will be found indicated by a double line or road, and by a white streak through 
the Ohio or Appalachian coal-field, and by a dotted line where I went by water, on the sea or the lakes.

Section I. Authorities.-I have given an alphabetical list on the map itself of the principal authorities for the geological colouring of this map, which, although very imperfect, will, it is hoped, be useful, in conveying a general idea of the distribution of the principal groups of rocks, especially in that portion of the territory of the United States in which so many admirable State surveys have been made under the direction of the State governments. The manner in which the map has been composed, and the relative approach to correctness of its several parts, will best be understood by the observations which I shall offer on the sources of my information, and by my explanation of the groups of rock represented by different colours.

\section{Maclure, Willifam.}

The earliest geological survey of America referred to in the construction of the present map is that accompanying Maclure's " Observations on the Geology of the United States," published at Philadelphia in 181\%. In this map he has represented, with great general accuracy, the "Alluvial Plain" (see p. 93, Vol. I.), bordering the Atlantic, and extending from Long Island to Louisiana and Texas. This plain includes the areas of the tertiary formations represented on my map. Parallel to the Alluvial Plain, Maclure has described the great "Hypogene," or "primary" district of the Atlantic Slope (see p. 93, Vol. I.), and has indicated its northern extension over the whole of New Hampshire, and over nearly 
all Maine, Vermont and Connecticut; he has also coloured in the detached mass occupying the northern part of the State of New York, between Lakes Ontario and Champlain. The broad belt of " $\mathrm{Pa}$ lœozoic rocks" stretching from Lake Champlain through the Appalachian ridges to the river Coosa in Alabama, and the isolated basin of Rhode Island, he has represented under the older epithet of "Transition." The sandstone of Connecticut and Pennsylvania, now classed as New Red sandstone, is coloured by him as Old Red; whilst, in the absence of positive information respecting the Western States, he coloured them all as "Secondary."

\section{Bayfield, H. W., Captain R. N.}

The earliest contribution of this indefatigable explorer of the geological structure of the northern parts of America, is contained in a paper on Lake Superior, published in 1829 in the First Volume of the Transactions of the Literary and Historical Society of Quebec. In this memoir the position and extent of the sandstone, and various trappean and primary rocks which surround the lake and compose its numerous islands, were described from a careful personal survey. The representation given on my map is taken from a coloured copy laid down by Captain Bayfield for me.

Since 1829, Captain Bayfield has explored a great part of the Lake and River coast between Lake Superior and the Gulf of St. Lawrence ; and in the present year he communicated to the Geological Society of London a paper "On the Junction of the Transition and Primary Rocks of Canada and La- 
brador," in illustration of which he presented an extensive suite of fossils to the Society, and supplied me with coloured maps of the district in question.

On these maps he has laid down the great region of hypogene or granitic formations extending from Labrador along the northern coast of the Gulf and River St. Lawrence to the northern shores of Lakes Huron and Superior; at intervals along this he has traced the oldest fossiliferous limestone (No. 15), forming the northern extremity of Newfoundland, the island of Anticosti, and the Mingan islands, the outlying mass on Lake St. John, many points on the river St. Lawrence, above and below Quebec, some of the Thousand Isles, and thence, crossing to Cabot's Head and the Manitoulins, where it appears to bend southward across Lake Michigan to the Wisconsin river.

From these maps I have also taken the coast of Chaleur Bay, Gaspe, the southern shore of the St. Lawrence, and many points in addition to, or confirming the information derived from other sources.

\section{Featherstonhaugh, G. W.}

In his "Tour in the Slave States," Mr. F. refers to his earlier geological surveys made in various parts of the United States.

From this work, and verbal communications, I have obtained much valuable information respecting the Alleghany Mountains, the Arkansas, and other Western territories; likewise in regard to the line of junction of the Primary and Silurian rocks on St. Peter's River, Missouri, and around the Ozark mountains. On Mr. F.'s authority I have extended the 
Cretaceous colour for a considerable distance along both banks of the Arkansas River; and he informs me that he has seen the same formation characterised by the abundance of Exogyra costata extending all the way to the sources of the Yellowstone river and Miscou.

Conrad, T. A.

Mr. C. published in 1832, "Fossil Shells of the Tertiary Formation of North America," in which he alludes to the extent of these deposits. He has also kindly presented me with a map of Alabama, in which, besides the limits of the Primary and Silurian districts of North Alabama and Tennessee, he has traced out those of a Lower Cretaceous region explored by him, extending from Tuscaloosa and Montgomery on the north to Claiborne and Columbia, where it joins and is covered up by the Eocene tertiary.

J Ackson, C. T. and Aluger, F.

A map of the geology of Nova Scotia was published by these authors in 1833, to accompany a memoir communicated by them to the American Academy of Arts and Sciences, vol. i., Cambridge; in which a great portion of the leading features of the structure of the country are exhibited. The first account of their survey was published in Silliman's Journal of Science for 1828-9.

Dr. Jackson is also the author of a Report on the Geological and Agricultural Survey of Rhode Island, 1840. From his map it appears that the western bar: of the State consists entirely of Primary rocks, 
which also form its eastern boundary. Rhode Island itself, and the bays and islands northwards, are coloured as Greywacke and coal, which I have represented as Old Red sandstone and coal.

In 1841 and subsequent years Dr. Jackson published various Reports, succeeded in 1844 by one large 4to volume, entitled "Final Report on the Geology and Mineralogy of the State of New Hampshire." The State consists entirely of Hypogene and Metamorphic rocks. The non-fossiliferous limestones of Haver Hill and Francisca are the only additions which, owing to the wholesale grouping of the rocks in the present map, I have been able to make, beyond the single colour used for the whole State in Maclure's map.

In the years 1837, 1838, and 1839, Dr. Jackson published three reports on the Geology of Maine, from which it appears that that great region consists almost entirely of Hypogene and Silurian rocks. As the latter have not yet been subdivided, or referred to their equivalents in other States, I have coloured all the fossiliferous tracts with one tint. Nos. 10-13.

\section{Hitchcock, Edward.}

Professor Hitchcock published his first Report on the Geology of Massachusetts in 1833, but the map of which I have availed myself, appeared in 1841, accompanying a new edition of his Report.

In this, the boundaries of the various metamorphic and primary rocks are laid down in great detail. The small scale of my present map only allows me to correct, the general outline originally given by Maclure.

voL. II. 
TAYLor, R. C., F.G.S.

In Mr. Hall's map of the Middle and Western States, published in his Geology of New-York, he acknowledges his obligation to Mr. Taylor of Philadelphia for a coloured map of the Eastern part of Pennsylvania, recording his own observations pre vious to the year 1834. I have adopted this part of $\mathrm{Mr}$. Hall's map, and have also before me that of Mr. Taylor, published in 1840, on which he laid down the position and extent of the outlying coal basins on the north-east of the great Appalachian coal-field.

Mr. Taylor is also the author of models to explain the geological structure of some of the ridges in the Alleghanies of Pennsylvania.

Rogers, H. D.

This eminent geologist published in 1839 , his map of the geology of New Jersey, the result of a State survey, of which I have availed myself. Although the Final Report and map of Pennsylvania, constructed during another elaborate survey, under the direction of the same geologist, has not yet been published, and consequently was not directly available for the present map, it is probable that some of the information obtained during the Pennsylvanian survey, and made public through various Reports, has found its way into the channels to which I have been indebted in the construction of my map.

ROGERs, W. B.

Mr. Hall acknowledges his obligations to $\mathrm{Mr}$. Slade, a member of the geological corps of the State survey of Virginia, so ably conducted by Professor 
W. B. Rogers, for the limits of the formations in Virginia, on which Reports have been published from the years 1836 to 1840 , by Professor R.

In regard to the newer coal of Eastern Virginia, the relation of which to the New Red sandstone was hinted at by Maclure, Mr. Rogers infers from the fossil plants that it is of the age of the Oolite. See Paper in Trans. of Assoc. of Amer. Geol., 1842, p. 298.

\section{Owen, David Dale, M.D.}

In November, 1842, Dr. Owen, the State Geologist of Indiana, communicated to the Geological Society an important paper on the Geology of the Western States, with a large suite of fossils and a map, which he most liberally gave me permission to make use of for this work, without waiting for the publication of the original. His map comprises the whole of the Illinois coal-field, and a considerable part of the Ohio or Appalachian coal-field. It comprehends indeed the geology of all the Western States watered by the rivers Ohio, Wabash, Illinois, Rock, Wisconsin, Cumberland, and Tennessee, lying between $35^{\circ}$ and $43^{\circ}$ of north latitude, and $81^{\circ}$ and $91^{\circ}$ of west longitude. It includes the States of Illinois, Indiana, Ohio, Kentucky, Tennessee, and the Dubuque and Mineral Point districts of the Territories of Iowa and Wisconsin. The observations recorded are the results of numerous excursions in these provinces, commenced in the year 1834, and continued to 1841 , by Dr. Owen, sometimes alone, at others accompanied by Dr. Troost and Dr. Locke, the State geologists respectively of Tennessee and Ohio. The 
territory under consideration occupies an area of about half a million of square miles (Proceedings of Geol. Soc. of London, November, 1842, Vol. iv., p. 1), and meets Mr. Taylor's Survey of the Pennsylvanian coal-field on the north-east, and the Cretaceous plain described by Conrad and Featherstonehaugh to the south.

\section{New York State Survey, 1836-1842.}

The State of New York having been divided into four districts, the geological survey of the first of these, comprehending the southern counties, was assigned to Mr. Mather, that of the second or northern counties to Dr. Emmons, the third district or central counties to Mr. Lardner Vanuxem, and the fourth or western region to Mr. James Hall.

The large map, comprising the result of their joint labours, has not appeared, but a compendium of it has been given by Mr. Hall in his geological map of the Middle and Western States, published in his Final Report, Albany, 1843. To this map, by Mr. Hall, and to that already mentioned by Dr. Dale Owen, I have been indebted for the principal portion of that part of my map which contains the Government Surveys of the Union.

Mr. Hall's map comprehends a sketch of the geology of Michigan, with which he was furnished by Dr. Houghton, the government surveyor of that State, who must therefore be considered as my authority for this region.

The observations of Dr. Hildreth, in the twentyninth volume of Silliman's Journal “ on Ohio," \&c., of Professor J. T. Ducatel, in Maryland, and Pro- 
fessor J. C. Booth, the geologist of Delaware, have been embodied by Mr. Hall in his map, which I have followed in regard to each of those States.

That portion of Mr. Hall's map which relates to Pennsylvania and Virginia, especially the ridges of the Appalachian mountains, is necessarily imperfect, in consequence of the unavoidable delay which has attended the publication of the splendid maps, now nearly ready, by Professors H. D. and W. B. Rogers, the surveyors of those States.

I have not had the advantage of seeing a geological map of the Western States, published by Mr. Byrem Lawrence, to which Mr. Hall refers.

Dr. Emmons published his "Final Report on the Second District of New York" in 1842. It contains geological maps of the counties of Jefferson and Clinton, and many detailed sections, extending from the great primary or hypogene district of New York across the Silurian basin of Lake Champlain into Vermont, where the primary reappears; giving, upon several different lines, the points at which the various strata appear at the surface. I have also profited by much valuable information respecting the geographical distribution of the rocks of Canada, \&c., in the body of Dr. Emmons' book.

Percival, James G

In 1842, Mr. Percival's " Report on the Geology of the State of Connecticut" appeared, with a map exhibiting, with great accuracy, the boundary lines of the various hypogene rocks, and the new red sandstone of the valley of the Connecticut, with the remarkable crescent-shaped masses of trap which oc$19^{*}$ 
cupy a considerable portion of its area. These traprocks are mentioned by Maclure, but their form, and the singular circumstance that they all lie in one direction, with their points eastward, was first made out by Mr. Percival.

\section{Dr. A. Gesner.}

In 1836, Dr. Gesner published " Remarks on the Geology and Mineralogy of Nova Scotia," with a small map, geologically coloured, in the construction of which he had been engaged some years before; but I am unable to record the exact date of his earliest observations.

In 1842 , he sent a much more detailed map to the Geological Society, to illustrate a memoir on the same subject, an abstract of which appeared in the Proceedings of the Society, and a sketch of the map itself subsequently in the Geological Journal, No. I, p. 34, 1845. In 1839 and the three following years, he issued four Reports on the Geological Survey of the Province of New Brunswick; but, as no map was published with them, I have only been able to glean a few particulars, sufficient, in connection with the MS. map with which Mr. Henwood has furnished me, to give a general idea of the structure of that province. In the last of these Reports, Dr. Gesner describes the coal-field of New Brunswick as occupying an area of 8,700 square miles, bounded on the south by a primary ridge extending from Shepody on the Bay of Fundy to the Oromoecto Lake, on the east by the Gulf of St. Lawrence, and on the north and west, as far as it has been explored, by palæozoic and primary rocks beyond the rivers Nashwack and Miramichi. 
'I'he whole of this great region presents a remarkably low and level surface, not averaging an elevation of more than $\mathbf{4 0}$ feet above the sea, the coastcliff of the gulf being only from 12 to 20 feet high; and the central tract, which separates the streams which flow west into the St. John's from those which have an easterly direction to the gulf, scarcely exceeding 150 feet.

Sandstone, containing coal-measure plants and fossil trees, also occurs on the northern shore of the Bay of Fundy, forming cliffs, which are occasionally 200 feet high, and present many remarkable contortions and dislocations of the strata, caused in some instances by protruding masses of trap-rock.

\section{Henwood, W. J., F.G.S., of Penzance.}

I am indebted to the kindness of this gentleman for a MS. map of New Brunswick, indicating the localities in which coal-measure strata occur all along the south shore of Prince Edward's Island, and on the opposite coast of Northumberland Straits and the Gulf of St. Lawrence, from Pictou Harbour, Nova Scotia, to Miscou Island, and along the south shore of Chaleur Bay. Also at many points in Passamaquoddy Bay, and along the whole course of the rivers Nashwack and Miramichi to Bathurst on Chaleur Bay.

Mr. J. W. Dawson, of Pictou.

From the map of the north-eastern part of Nova Scotia, sent to the Geological Society by this gentleman, of which a sketch was given in the first number of the Journal of the Geological Society, London, 
1845, No. I, p. 26, and of which an improved edition will be given in the third number of that journal, I have corrected part of Dr. Gesner's map of Nova Scotia, so far as the small scale of my own could allow. On Mr. Dawson's authority, also, I have coloured Prince Edward's Island as carboniferous, as he has shown that the sandstone there contains coal plants throughout.

Mr. Richard Brown, of Sydney, Cape Breton.

From two papers and a map communicated by him to the Geological Society of London (see Quarterly Journal, No. I, p. 23, and No. II, p. 207), I have been able to give the geology of the island of Cape Breton.

\section{Prince of Neuwied.}

The valley of the Missouri around the "Great Bend" has been coloured as Cretaceous upon the authority of the Prince of Neuwied. Mr. Römer has given the following extracts from his recently published work:- "Reise des Prinzen Maximilian von Wied zu Neuwied in Nord-America."

P. 75. "In the environs of Fort Clark on the Mississippi, all the hills consist of sandstone with Baculites and other shells, which are found everywhere on the Missouri, and on its tributary rivers. Fossil bones have been often found; whole skeletons of Saurian animals, more than fourteen feet long, frequently occur farther down the Missouri : one of these, found near the Big Bend, I brought home, and it has been described as a new species of Ichthyosaurus by Professor Goldfuss." 
P. 513. "We found here (near the mouth of the Mussel-shell river, Missouri) many shells, and among them very large and fine Baculites."

Baron Leopold von Buch informs me that the late Mr. Nicollet's map, which I have not seen, would have enabled me to give a greater extension to the cretaceous strata in the Far West.

Section II. Geological Formations expressed by different Colours and Numbers on the Map.

No. 1. Alluvium and Post-Pliocene.-One tint is employed to represent everything newer than the chalk. The spaces occupied by tertiary strata are indicated by dotting or by crosses, as in Nos. 2 and 3. I am aware that many parts to which I have been unable to extend these markings are really tertiary.

No. 2. Miocene.-The island of Martha's Vineyard has been referred by me to this period, as well as other districts, the area of which is sketched out in the 6th chapter of this work, p. 132, Vol. I., and a more full account of which will be given in the 4th No. of the Quarterly Journ. of the Geol. Soc. London, 1845.

No. 3. Eocene.-A short account is given by me of what I observed of these strata, in the 9th chapter, p. 174, Vol. I., and a more detailed paper will be given in the 4th No. of the Quarterly Journ. of the Geol. Soc. London, 1845. I have by no means been able to mark all the points at which $\mathrm{Mr}$. Conrad and others have seen the outcrop of these formations, to which I have also referred the white limestones of 
the Santee river and some other places, classed by several preceding observers as Upper Cretaceous.

No. 4. Cretaceous. - The strata indicated by this colour in New Jersey, are described in the 4th chapter, p. 77, Vol. I., and in my paper in the Quarterly Journal of Geol. Soc. No. I. I have already alluded to the authorities on which various regions of the map have been delineated as cretaceous.

No. 5. Coal (Oolite?) Virginia.-I have already mentioned (p. 207), that Professor W. B. Rogers considers the plants of the newer coal of Virginia to agree very closely with those of the oolitic formations of Europe. I have therefore distinguished the coal field near Richmond in Virginia, which I did not visit, by a different figure (No. 5) from the formation next in succession, or No. 6.

No. 6. New Red Sandstone and Trap.-The probable age of this formation has been discussed by me in the 6th chapter, p. 125, Vol. I., it being still a question whether it should be referred to the upper or lower New Red, to the Trias or Permian groups of Europe. This sandstone, in the valley of the Connecticut and elsewhere, rests on hypogene rocks, and contains the footprints of birds and numerous fish of a genus allied to Paleoniscus.

No. 7. Coal Measures.-I have alluded to the Illinois and Appalachian coal-fields at pp. 81, 86, Vol. I. ; and at pp. 25, 26, Vol. II. That of Nova Scotia has been mentioned in the 24th and 25th chapters, Vol. II., and in my reference to Dr. Gesner, Mr. Brown, and Mr. Dawson as authorities.

No. 8. Carboniferous Limestone and Gypsum of Nova Scotia.-This formation, when it is represented 
as forming a belt round the Ohio and Michigan coalfield, as shown by Dr. Dale Owen and Dr. Houghton, consists of limestone containing fossils by which it can be referred to the mountain limestone of Europe. No gypsum is there associated with it, but I have shown in the 25th chapter, Vol. II., that the lower carboniferous rocks of Nova Scotia assume a very different aspect from those in the United States, consisting of sandstone and red marl, with large masses of interstratified gypsum and marine limestone with true carboniferous fossils.

No. 9. Old Red Sandstone, or Devonian.-In order to understand the divisions comprehended under this and the following heads, from 10 to $\mathbf{1 6}$ inclusive, it will be necessary to refer to the classification adopted by the surveyors of New York in their geological reports, of which the following Table is given by $\mathrm{Mr}$. Hall in his "Final Report," p. 18. 
Geographical subdivisions.

\section{Systematic subdivisions, founded upon the} fossil and lithological characters.

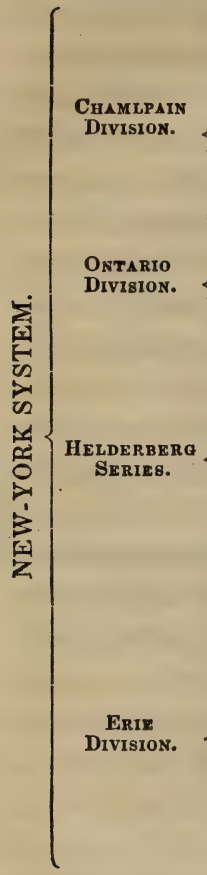

1. Potsdam sandstone.

2. Calciferous sandrock.

3. Black-river Limestone group, embracing the Chazy and Birdseye.

4. Trenton limestone.

5. Utica slate.

6. Hudson-river group.

7. Grey sandstone.

8. Oneida or Shawangunk conglomerate

9. Medina sandstone.

10. Clinton group.

11. Niagara group, including shale and limestone.

12. Onondaga-salt group.

13. Water-lime group.

14. Pentamerus limestone.

15. Delthyris shaly limestone.

16. Encrinal limestone.

17. Upper Pentamerus limestone.

18. Oriskany sandstone

19. Cauda-galli grit.

20. Schoharie grit.

21. Onondaga limestone.

22. Corniferous limestone.

23. Marcellus slate.

Moscow shales.

24. Hamilton group. $\left\{\begin{array}{l}\text { Encrinal limestones. } \\ \text { Ludlowville shales. }\end{array}\right.$

$\underset{\text { Division. }}{\text { Erix }}\left\{\begin{array}{l}\text { 25. Tully limestone. } \\ 26 . \text { Genesee slates. }\end{array}\right.$

27. Portage or Nunda group. $\left\{\begin{array}{l}\text { Portage sandstone. } \\ \text { Gardeau flagstones. } \\ \text { Cashaqua shale. }\end{array}\right.$ 28. Chemung group

No. 9 of my map includes Nos. 26, 27, and 28, or the Genesee, Portage, and Chemung groups, forming the upper or newer part of the Erie division of the New York system. Some allusion will be found to this formation, Vol. I., p. 58, and Vol. II., pp. 9-46. No. 10.-Hamilton Group.-This formation includes the Moscow and Ludlowville shales, and the Marcellus slate of the above table of the New York system, and corresponds in many of its fossils with 
the Ludlow rocks of Mr. Murchison's Upper Silurian group.

No. 11. Helderberg Series.-This division includes that portion of the Upper Silurian rocks of the above Table, which comprises the formations from 22 to 14 inclusive. Mr. Hall mentions that, after leaving the western extremity of Lake Erie, the Niagara limestone, the Onondaga salt group, and the Helderberg limestones (Nos. 13, 12 and 10 of my map), are so blended together, that it is impossible to define their limits in the same manner as in New York. He has therefore united them in his map; and represented them under one colour in Ohio, Indiana, and Illinois ; and I have followed the same plan.

No. 12. Onondaga Salt Group.-This remarkable formation of red and green argillaceous shale, marl, and shaly limestone, with veins and beds of gypsum, and productive brine springs acquires a thickness of 1000 feet in New York, near the Niagara region, and in the county of Onondaga, where it is largely developed; but it is a group of partial extent in the Upper Silurian division.

No. 13. Niagara and Clinton Groups.-These, it will be seen, form the chief part of the Ontario division of the New York system. The Niagara limestone and shale correspond in their fossils with the Wenlock or Dudley limestone of England, and would therefore be classed by Mr. Murchison as Upper Silurian.

The Clinton group, as containing the Pentamerus oblongus in abundance, would be considered in England as Lower Silurian; but Messrs. Murchison and De Verneuil regard this fossil in Europe generally as VOL. II. 
on the dividing line between the Upper and Lower Silurian rocks. I have thought it most corrvenient in this instance to unite the Clinton and Niagara groups.

No. 14. Hudson River, Utica, \&c.-In this group I have included the formations from Nos. 5 to 9 inclusive, of the table of the New York system. The Medina sandstone, the Hudson River rocks, and Utica slates, comprise a number of arenaceous and argillaceous strata, which separate the Niagara and Trenton limestones, and which contain fossils corresponding to part of the Lower Silurian of Europe.

No. 15. Limestone of Trenton, \&c.-This group includes Nos. 3 and 4 or the Trenton and Bird's-eye divisions of the New York table, and the blue limestone of Cincinnati. (See p. 42, Vol. II.) The fossils brought by Capt. Bayfield from the island of Anticosti, and by Dr. Bigsby from the Manitoulin Islands, seem to imply that, near the northern limits of the Silurian rocks, the lowest group, containing Spirifer lynx, and other ancient fossils, and the newer calcareous formations, abounding in Pentamerus oblongus and Favosites Gothlandica, are closely contiguous, and cannot perhaps be divided.

No. 16. Potsdam sandstone, $\&$ c.-This group comprehends Nos. 1 and 2, or the Potsdam and calciferous sandstones, of the New York system, being the lowest formation containing organic remains in New York and on the St. Lawrence.-See pp. 106, 133, Vol. II.

Z. Sandstone of Lake Superior.-This sandstone was formerly considered as belonging to the Old Red by Capt. Bayfield; butt, as he has obtained no fossils 
from it, its age must be considered as undetermined, and he is now inclined to regard it as the equivalent of the Potsdam sandstone. The small oval marks engraved on the area of the hypogene rocks on the north shore of Lake Superior, indicate points where Capt. Bayfield has seen this sandstone overlying the granitic rocks.

a. Hypogene (Granite, Gneiss, \&c.)-Under this head I have comprehended all the formations formerly called primitive or primary, whether stratified or unstratified, plutonic or metamorphic. They are non-fossiliferous, and I have discussed their chronological relations in the 21 st chapter, at pp. 108 to 112 , Vol. II

b. Trap Rocks.-Trappean rocks of various ages are indicated by crosses, which it will be observed are different from those used for the Eocene strata.

c. Metamorphic Limestone.-The non-fossiliferous crystalline limestones or marble of the hypogene or primary class are indicated by this character.

Note.-I have to acknowledge the co-operation of Mr. Woodward of the Geological Society in assisting me in collecting the various maps from which the present one has been compiled, and in selecting and arranging the colours.

\section{Plate III.}

Map of the Niagara District.

The signification of the six subdivisions of the Silurian system of New York, represented in this map, will be understood by referring to the preceding description. It will be seen that the Helder- 
berg limestone, No. 1, is the same as one of the Upper Silurian formations, or No. 11, of the large map; that No. 2 corresponds with No. 12, and Nos. 3 and 4 with No. 13, while No. 6, or the Medina sandstone, is included in the large map in No. 14, and considered a member of the Lower Silurian group. In the Niagara district, it is constituted partly of a hard white quartzose sandstone, but chiefly of red sandstone and red marl. This map is referred to at p. 30, Vol. I.

It will be seen that the same Nos. are used in the section at the side.

The usual position of North and South has been reversed in this map, in order that it might correspond with the bird's-eye view, $\mathrm{Pl}$. I.

\section{Plate IV.}

Fac-simile of a view of Niagara Falls, by Father Louis Hennepin.-(From the original Utrecht edition, 1697.)

This view is referred to at p. 35, Vol. I. The ship introduced by Father Hennepin is, I presume, a conventional sign for water, as at that period, Lake Erie had only been navigated by canoes.

\section{Plate V.}

Fossil mammalian remains from the tertiary strata of Martha's Vineyard, Massachusetts.

An account of the fossil walrus, fig. 1, will be found in Vol. I., p. 258. In regard to the two ver- 
$t$ bræ of different genera of cetaceans, the whale and dolphin, the reader is reminded that they have been reduced to one fourth of their natural size, so that they must have belonged to individuals of very large dimensions.

\section{Plate VI.}

View of the great coal seam on the Monongahela at Brownsville, Pennsylvania.

A description of this plate is given at p. 22, Vol. II.

\section{Plate VII.}

Recent footprints of birds, the Sandpiper (Tringa minuta), on the red mud of the Bay of Fundy, Nova Scotia-natural size.

A full account of these impressions of the footsteps of birds, fossilized in red marl deposited by the waters of the Bay of Fundy in July, 1842, will be found at p. 140, and the following pages, Vol. II. The specimen has been presented by me to the British Museum. 



\section{INDEX.}

A.

A bozitron of slavery, i. 153-156.

Abolitionists, precautions against, i. 146. - mischief caused by, i. 149.

Aboriginal race, Dr. Morton on the, ii. 32.

Ague, i. 126, 142.

Albany, - tate geological survey, i. 13.

Albion mines, ii. 191.

Alger, Mr. F., Map of Nova Scotia, ii. $144,204$.

Alien voters, i. 180.

Alleghanies, ridges of, i. 66 ; ii. 7 .

- , crossing the, ii. 21 .

Allegators, i. 128.

Aliuvial terraces at Cincinnati, ii. 50.

Alluvium and post-pliocene, ii. 213.

Amboy Strait, ii. 5.

Annelides, tracks of, ii. 140.

Anthracite of Pennsylvania, i. 65, 197.

Appalacrian chain, i. 66.

- , structure of, i 73 .

_ coal field, i. 71 ; ii. 26.

, area of, ii. 29.

- and Illinois conl fields, supposed

former continuity of, ii. 41.

Architecture, money sunk in, i. 89.

Ardoise Hılls, ii, 137-139.

Association of American Geologists, i. 208.

Astarte Laurentiana, ii. 125.

Asterophyllites, ii. 166.

Astor, Mr., i. 193.

Asylum, blind, i. 92.

Atlantic plain, i. 106 ; ii. 201.

Atmosphere, clearness of, at New York, i. 11 .

Augusta, i. 123.

Ausable River, ii. 131.

B.

Bachman, Dr., i. 137,

Bakewell, Mr., view of Niagara, i. 24.

Baltimore, i. $10 \%$.

- metamorphic rocks, ii. 6 .

Bank notes, i. 172.

Banks, S. of Newfoundland, i. 2.

Bartram on Licks, ii. 54 .

Bath, N. Y., slates of Old Red, i. 47.

Bayfield, Capt., ii. 122, 129, 191, 202.

Bears in Virginia, i. 118.

Beauty in Georgia, i. 131.

Beaupnrt, marine fossils, ii. 122. boulders, ii. 123.

- , small variety of shells, ii. 129.
Beavers, wood gnawed by, ii. 193.

Beck, Dr., ii. 122, 123.

Benedict, Prof., ii. 128, 131.

Bequests for education, i. 89.

- for national parposes, i. 209.

Big bone Lick, ii., 54, 59.

mastodon bones, ii. 56 .

- shells, ii. 57 .

Binney, Mr., on stigmaria, ii. 156.

Birds not vocal, i. 51.

- foot-tracks of, i. 200.

, foot-prints, Nova Scotia, ii. 141.

Blind asylum, i. 92.

Blomidon, Cape, ii. 143.

Blossberg conil, stigmaria, i. 49.

Blue limestone of Cincinnati, ii. 43. fossils, ii. 43.

Boarding-houses, ii. 134.

Bogs in Kentucky, ii. $\mathbf{j 4}$

Booth, Mr. J. C., ii. 209.

Boston, plants near, i. 4.

—, drift near, i. 5-7.

- marine shells, ᄂ. 5 .

_ railways, i. 8 .

— advantages of, i. 85 .

- , society in, i. 98 .

_- sleigh-driving, i. 99.

- - meeting of American geologista at, i. 208.

, fourth arrival, ii. 134.

Boulders of Long Island, i, 191. 105 .

- between Montreal and Quebec, ii. 120.

Bowman, Mr., ii. 154, 163.

Brachiopoda, ii. 44.

Braddock, General, grave of, ii. 20.

British settlers unable to speak English, ii. 95 .

- possessions in America, population of, ii. 102.

Bronkfield, N. Scotia, ii. 181.

Brooklyn, i. 189.

Brongniart, M. Adolphe, on stigmaria, if. $17,15 \%$.

Brown, Mr. Richard, ii. 191, 212.

Brownsville coal, ii. 22.

Brygon swamp, i. 139.

Biddle, Mr., ii. 161.

Buffalo trail, Big Bone Lick, ii. 55.

$\longrightarrow$, town of, ii. 75.

Bunbury, Mr. Charles, ii. 165, 170.

Burlington, Vermont, drift of, ii. 128.

$\longrightarrow$, town of, ii. 131.

Burning-spring at Niagara R., ii. 75.

Burr stone, i. 126.

Butterflies, i. 20. 
c.

Calamites, upright, ii. 164.

, list of species, ii. 170 .

Cambridge University system, i. 215.

-, Dr. Peacock on, i. 230.

, youth of teachers, i. 230.

, private tutors or "crammers," $i$. $230,23 i$.

-, transference of tuition to college

tutors, i. 238.

, Trinity and St. John's colleges, i. 239.

_- clerical professors, i. 241.

- Dr. Whewell's treatise, i. 241, 248. , Massachusetts, i. 92.

Canada, ii. 96.

—, bad roads, ii. 99.

- French farmers, ii. 99

-, Scotch emigrants, ii. 98

_ , soldiers, ii. 98.

- military aspect of, ii. 100.

__ " "Sympathizers," ii. 100.

Geological survey, ii. 103.

Cape Breton, coal measures, ii. 175. coal plants, ii. 165.

- mountain limestone, fossils of, ii. 165.

Capital and metropolis, separation of, $i$. 193.

Carbonic acid, atmosphere of, i. 120.

Carboniferous rocks, thickness of, i. 69.

- limestone fossils, list of, ii. 165.

flora, wide range of, ii. 17.

list of, ii. 165.

Carolina, S., Eocene strata, i. 138; pre-

face, $v$. malaria in, i. 143.

Cave Hall, white limestone, i. 140.

Cedars, i. 124, 120.

Chalk of New Jersey, i 62.

Champlain lake, plants, ii. 133. - scenery of, ii. 130.

Channing, Dr., ii. 1.

Charleston, i. 182.

- , severe frost, i. 137.

Charter of Charles II., Rhode Island ii. 2.-

Chignecto Channel, ii. 150.

Chilmark strata, i. 295.

Churches, voluntary system, i. 162.

_- episcopal, i. 163.

Cincinnati, ii. 38.

- blue limestone, ii. 42.

$r$ bones of elephant, ii. 51 .

—, associated shells, ii. 51 .

— " pork aristocracy," ii. 61.

- alluvial terraces, ii. 50 .

City Point, i. 107.

Civilisation, progress of, i. 59 .

Clay, nodules of, ii. 127.

Clergy, salaries of, i. I64.

Cleveland "lake ridges," ii. 71.

- alluvial terraces, ii. 74 .

"Cliff limestone," ii. 41.

Climate of N. America, i. 8.

- of miocene period, i. 110.
Climate of U. S., i. 194

Clinton group, ii. 217.

Coaches, i. 46 ; ii. 62.

Coal oolitic, of Virginia, ii. 214

— measures, Nova Scotia, ii. 148

— plants of Nova Scotia, ii. 158.

- list of, ii. 165-171.

- formed by growth of plants in situ,

ii. 161.

— debituminization of, i. $\mathbf{7 2 ,} \mathbf{1 9 7}$. , origin of, i. 118.

— of Frostburg, ii. 13.

-, stigmaria and marine shells, ii. 15.

- plants, ii. 16.

- on the Ohio, abundance of, ii. 22.

—, vast area of, ii. 25.

— plants of Marietta, ii. 35.

- plants of Pomeroy, ii. 37.

Cobequid hills, ii. 190.

Codrington, Col., ii. 114, 121.

Coggin's Point, i. 107.

Congress at Washington, i. 103.

$\longrightarrow$ good faith of, i. 179 .

Connecticut valley, i. 1?.

- yeomanry, i. 101.

— river,-footmarks, i. $\$ 201$.

Conrad, Mr., i. 63 ; ii. 204.

- Trilnbites of New York, ii. 45.

Conper River, i. 138.

Corals, Timber Creek, i. 64.

Corduroy road, ii. $63,94$.

Corniferons limestone, ii. 81.

Côte de Neige, shells 500 feet high, ii. 119.

— St. Pierre, sheliy gravel, ii. 118.

Crabs, i. 133.

Cretaceous gronp, ii. 214.

- strata of New Jersey, i. 62, preface, p. iv.

Cumberland coal-field of Maryland, ii. 14.

— of Nova Scotia, ii. 163.

D.

Daguerreotype view of the Horse-shoe Fall, ii. 77.

Darwin, Mr., on coral reefs, ii. 91.

Dawson, Mr. J. W., ii. 181, 211.

Debert River, Nova Scotia, ii. 181.

Debituminization of coal, i. 72, 197.

Deep sea strata, ii. 47 .

Delaware, flood on, i. 82.

Democracy, effects of, i. 180 ; ii. 194.

Democratic movement in Rhode Island, ii. 2.

Denudation of Alleghanies, ii. 18.

"Detector," i. 171.

De Tocqueville, on the progress of emigrants in Ohio, ii. 65.

De Verneuil, M., Silurian system of Scandinavia and Russia, ii. 44.

on Nova Scotia fossils, ii. 182.

Devonian rocks in the Appalachians, $\mathrm{i}$. 47 ; ii. 8, 45. 
Dickens, Mr. Charles, reception of, i. Fiddler crabs, i. J33.

158.

Divinity schnols, i. 211.

Dorr, leader of Rhode Island insurgents, ii. 4 .

Drift at Beauport, near Quebec, ii. 123.

- at Keeseville, ii. 127.

near Boston, i. 5-7.

_ of South Brooklyn, i. 190.

- of Burlington, ii. 123.

- at Niagara Falls, ji. 78.

- northern, age of, ii. 59.

- of the St. Lawrence, ii. 116.

- at Lake St. Peter, ii. 120.

Ducatel, Mr. J. T., ii. 208.

Duncan, Mr., ii. 192.

Durham county, ichthyolites, i. 100.

snow storm, i. 101.

\section{E.}

East R. of Pictou, ii. 191.

Eaton, Professor, i. 54.

Ebenezer causeway, i. 129.

Education, compulsory, i. 94.

Educational funds, i. 90.

Election at Trenton, i. 83.

at Philadel phia, i. 83.

Electoral body, reform of, i. $18 \%$.

Elephants' bones at Cincinnati, ii. 51.

Emancipation in West Indies, i. 148, 152-167.

Enigrants of German origin, ii. 12.

Emmons, Dr., Taconic system, i. 195.

-, rocks of Lake Champlain, ii. 81 .

-, ii. 209.

Eocene organic remains, i. 129.

- limestone of Wilmington, i. 156. - shells, i. 142.

white limestone, i. 141.

strata of S. Carolina and Georgia,

i. 138; preface, p. v. , ii. 213.

Fiscopal church, i. 163.

Equality, ii. 194.

of sects, i. 96.

spirit of, i. 49 .

Erratics near Boston, i. 5. at H:mpden, i. 10.

- of Long Island, i. 189.

- of Martha's vineyard, i. 203.

Essex co., N. Y., shclls in drift at, ii. 127.

Eutaw, corals and shells, i. 141.

Evergreen, Va., masses of coral at, i. $10 \%$.

\section{F.}

Farmers of Connecticut, i. 101

Fentherstonhaugh, Mr. G. W., i. 71; is. 203.

Fees of puhlic lecturers, i. 89.

Ferns in fructification, ii. 16.

Fever and ague, i. 126, 142 .

Financial crisis, i. 172.

Fire, alarms of, i. 61.

Fire-flies i. 11; ii. 59, 94, 135.

Fish in old red sandstone, i. 48.

- in Silurian rocks, ii. 48 .

Creek, Indian corn, ii. 28.

Flood on the Delaware, i. 82.

Florida war, i. 136.

Foot-prints of birds, Nova Scotia, ii. 141.

Footsteps, supposed reptilian, ii. 177 .

Forbes, Prof. E., on marine fauna, ii. 49.

Forest in Kentucky, ii. 53.

- on fire, ii. 190.

Forests of fossil trees, ii. 153.

Fossil trees upright, ii. 161.

Fossils, list of Nova Scutia carboniferous limestone, ii. 165, 171.

Frederick, metamorphic rncks, ii. 6.

Fredonia, natural gas, ii. 74 .

- sand ridge, ii. 74 .

French farmers, ii. 99.

Freshwater shells, i. 161.

Frost at Charleston, i. 137.

Frostburg iron mines, ii. 13.

-, analysis of coal, ii. 14 .

_ numerous seams of coal, ii. 15.

- , outliers of quartzoze grit, ii. 18.

_ , skunk, ii. 19.

- family of emigrants, ii. 12.

Fundy, Buy of, tides, ii. 139.

—, the Bore, ii. 140.

Fured mud, ii. 140.

Furrows, glacial, recent, in Nova Scotia, ii. 144.

G.

Gannanoqui polished rocks and boulders, ii. 115.

Gayhead Cliffs, Martha's Vineyard, I. 205.

- Indians settled near, i. 206.

Gebbard, Mr., i. 54.

Genesee Upper Falls, i. 45.

, fossil mastodon, i. 45.

Geological survey of Canada, ii. 102.

- New York, i. 13.

Geologists, association of American, $\mathbf{i}$. 208.

Genrgia, Eocene strata of, i. 138; proface, p. v.

German patois, i. 81.

- Pennsylvanians, i. 182.

_ "log-rolling," i. 183.

- emigrants, ii. 12.

- settlers, ii. 68 .

Gesner, Dr., ii. 150, 157, 210.

Girard College bequest, i. 89.

Glacial theory, i. 7 .

furrows in Canada, ii. 113.

144 144.

14. furrows near Halifax, ii. 136.

Goat Island freshwater deposit, i. 29.

Gopher, i. 128.

Gould, Dr., ii. 129. 
Great Dismal swamp, i. 114.

Mr. E. Ruffin's description, i. 114.

higher than surrounding country,

i. 115 .

accumulation of peat, i. 116

trees and shrubs, i. 116.

buried timber, i. 117.

lake in the centre, i. 117.

bears and wild cats, i. 118.

Green, Capt. George, ii. 15.

Green mountains, ii. 133.

Greensand, cretaceous, i. 63.

Grooves on Niagara limestone, ii. 82.

Grove, South Carolina, i. 136.

- landing, shells, is 108.

Gypsum, ii. 180, 215.

- of Nova Scotia, age of, ii. 172-187.

\section{H.}

Habersham, Dr., i. 130.

Halifux, harbour, \&c., i. 2

- steamers, ii. 196.

glacial furrows, ii. 136.

Hall, Mr. James, i. 18; ii. 208.

Hampden, errat: : block, i. 10.

Hamiiton grouf, ii. 216. 221

Harlan, Dr., i. 160.

Harper's Ferry, Virginia, ii. 6.

Harrison, General, on Indian mounds, ii. 30.

Harvard University, i. 92.

...-College, i. 214.

- professors and tutors, i. 214.

- examinations, i. 215.

Hayes, Mr. J. L., on icebergs, ii. 83.

IIelderberg mountuins, i. 54. series, ii. 217.

"Helderberg war," i. 55.

Hennepin's description of Niagara Falls, i. 28.

Henwond, Mr. W. J., ii. 211.

Heyner's Bridge, i 130.

Highlan.l settlers, ii. 189.

Hildreth, Dr., ji. 29, 208.

Hitchcock, Professor, drift of Amherst, i. 199 ; ii. 205.

Hoboken, serpentine cliffs, i. 189.

Holoptichius, i. 47 ; ii. 178.

Holyoke, Mount, plants, i. 202.

Horseshoe Fall, i. 25.

- prssing under, ii. 76.

- Daguerreotype view of, ii. 77.

Honghton, Dr., ii. 208.

Hubbard, Professor, ii, 133.

Hudson city, Silurian rocks, i. 195.

River group, ji. 218.

River scenery, i. 13.

Human bones fossilized, i. 159. skull, i. 136

Humming birds, ii. 191, 192.

- at Newhaven, i. 10.

tameness of, i. 51.

Hypogene rocks, ii. 106.
$\mathbf{I}$

Ice of New England, i. 9. action of, ii. 146.

Icebergs, i. 138 ; ii. 83.

Ichthyolites of Durham, Connecticut, i. 99 .

in Old Red sandstone, ji. 48.

Illinois and Appalachian coal fields, supposed former continuity of, ii. 41.

Indians near Gayhead, i. 206. of Ohio Valley, ii. 32.

Indian corn found fussil on the Ohio, ii. 28.

- mounds, ii. 28.

civilisation, ii. 33,34 .

Indian suminer, i. 85.

Infusorial clay, i. 107

1rish voters, i. 182.

College, intolerance, i. 213.

Italian scientific " congress," i. 235.

J.

Jack Porter Mine, Maryland, ii. 16.

Jackson, Mr. C. T., ii. 144, 204.

Jacques' Cartier River shells, ii. 121.

James River, i. 107.

Jenning's Run, Frostburg, outliers of quartzoze, grit, ii. 18.

Jogginers, ii. 162.

Joggins, South, ii. 154, 159.

Joinville, Prince de, i. 97.

Jones, Colonel, i. $12 \%$

K.

Kalm's description of Niagara Falls, i. 29.

Keeseville drift, ii. $12 \%$.

- Lingulæ, ii. 131.

Kentucky farmers, ii. 12.

- bogs, ii. 58 .

"Killing-time," i. 15.

King Crab, i. 207.

Kingston, ii, 182.

I.

Labour compulsory in Europe, i. 89.

Lake in Great Dismal, i. 114.

Ridges, ii. 86.

Ridges, near Cleveland, ii. 71.

La Prairie, ii. 130.

Laura Bridgman, i. 92.

Laurel Hill, ii. 20.

Lea, Mr., fluviatile shells, i. 160.

Lectures at Lowell Institute, i. 86.

, invitations to deliver, i. 194.

- attended by labouring classes, $\mathbf{i}$. 199.

in Oxford university, i. 225.

in Cambridge university, i. 240.

Lehigh Summit Mine, i. 68, 82, 197. 
Lepidodendron, ii. 166.

Lepidostrobus, ii. $16 \%$.

Le Roy Fall, i. 45.

Libraries in Massachusetts, i. 210.

Licks, ii. 53.

Liebig, Professor, on the state of feeling towards science in England, i. 245.

Lime-sinks, i. 140.

Lingule in sandstone, ii. 132.

Linniea borealis, ii. 138.

I. iterary works, Jarge sale of, i. 210.

Liverpool, arrival at, ii. 196.

Locke, Dr., ii. 29, 40, 207.

"Log-rolling," i. 183.

Logan, Mr., geological survey of Canada, i. 50 ; ii. $103,173$.

Long Island, erratic biocks, i. 189.

Lowell Institute lectures, i. 86. oral instruction, i. 88.

- fees of lecturers, i. 89.

Institute, costly buildings, i. 89 .

Mr. John, i. 92.

factories, i. 93 .

M.

Maclure's geolngical map, i. 105.

- , Mr. W., ii. 201.

McCord, Mr., shells at Côte de Neige, ii. 119 .

Malaria in South Carolina, i. 143.

Manmalia, i. $19,45,54,130,136,139$

Manners, i. 57.

Marietta coal measures, ii. 35 .

- psarolites, ii. 35 .

Martha's Vineyard bones, i. 204. erratic blocks, i. 206. Indians of, i. 206.

Maskinongé, falls of, ii. 120.

Massachusetts, libraries in, i. 210.

Mastodrn remains near Rochester, i. 19. at Niagara Falls, i. 41.

_ at Genesee, i. 45.

- near Hudson River, i. 54.

- in Genrgia, i. 130.

- in Brygon swamp, i. 139.

_ skeleton from Missouri, i. 160. bones in Kentucky, ii. 57.

Mather, Mr., report of New York, i. 191. ii. 91 .

ii. 208 .

Manch Chunk, i. 69, 197.

Metamnrphic limestone, ii. 219.

Metropolis and capital, separation of, $\mathbf{i}$. 193.

Mexicans, ancient civilisation of the, ii. 32.

Millhaven, Genrgia, i. 127.

Minudic, upright trees near, ii. 150.

Mincene strata of Virginia, i. 105; preface, p. v.

- period, climate of, i. 110. marls of Wilmington, 156. formations, ii. 218 .

-Mirage" on Lake Ontario, ii 85.
Mississippi, repudiation of, i. 185.

Mocking bird, i. 142.

Mohawk valley, i. 15.

Monongahela River shells, ii. 27. - coal on the, ii. 2.2 .

Montmorenci, falls of, ii. 105, 126.

- , polished gneiss, ii. 114.

Muntreal, French aspect of, ii. 96.

- the seat of government, ii. 96 .

- mountain of, ii. 116.

- shells, ii. 117 .

$\longrightarrow$, height of shells, ii. 119.

, tin-covered houses, ii. 130.

"Moraines," i. 199.

Morris, Mi., ii. 165.

Morton, Dr., i. 00.

$\longrightarrow$, Aboriginal Indians; ii. 32.

Mosquitoes, ii. 98.

Mount Vernon, i. 158.

Mountains of New York, ii. 131.

Mountain limestone fossils, ii. 182.

"Mover's House," ii. 63.

Muddy River, i. 33.

Murchison, Mr., Silurian system of Scandinavia and Russia, ii. 44.

Museum at Washington, i. 102.

Mytilus edulis fossil, ii. 117.

\section{N.}

National Road, ii. 7

Negroes, natural capacities of, i. 152; ii. 34 .

-, wealthy, social position of, i. 164.

- , free, depression of, i. 164.

—, sacrament, administered to, i. 168.

- repugnance to associate with, $i$. 168.

-, reservations, i. 170. (See Slaves.)

Nereites in Ticonic mountains, i. 195.

Neuropteris, ii. 108.

Neuwied, Prince of, ii. 212.

New Brunswick coal field, ii. 210.

New England, good faith of, i. 186.

- universities, i. 211.

- divinity schools, i. 211.

— theological colleges, i. 211.

- early age- of quitting college, $i$.

214.

Harvard college system, i. 214.

-, trees, ii. 5.

Newfoundland fog banks, i. 1 .

Newhaven, i. 10

- red sandstone, i. 10.

New Jersey cretaccous strata, i. 62 , pre face, $p$. iv.

- New Red sandstone, i. 12.

- trees, ii. 5.

New Red sandstone of Connecticut

River, i. 200.

—, New Jersey, i. 12.

-, Durham, Connecticut, i. 99.

$\longrightarrow$, ii. 214.

New York, mountains of, ii. 131.

- savings' bank. i. 173 .

- island, i. 189. 
New York, migratory condition of, $i$. 192.

New York sympathizers, ii. 101.

Geological survey, i. 13.

Niagara Falls, scenery, i. 22.

- vapoury clouds, i. 22.

__, Mr. Bukewell's view, i. 24.

$\longrightarrow$, descri, tion of, i. 24.

- recession from Queenston, i. 25.

- rate of recession, i. 27.

28

28. Kalm's description, i. 29.

_, slope of the river, i. 31 .

_, Goat Island deposit, i. 29.

_ ancient river bed, i. 30.

-_, Muddy Kiver sand, i. 33.

- Devil's Hole, i. 34.

-, Bloody Run, i. 34 .

_ future recession, i. 36.

$\longrightarrow$, origin, i. 36 .

- , successive changes, i. 38.

-, St. David's ravine, i. 39.

_- vast lapse of past time proved by, i. 41 .

_, "Burning Spring," ii. 75.

- drift, ii. 77 .

_ river, course of the, ii. 76 .

- limestone, gioves on, ji. 78 . , district, supposed geological changes in, ii. 84 .

Nicollet, M., i. 198, ii. 213.

Nomenclature of places, i. 52.

North Carolina pine forests, i. $15 \%$.

Nova Scotia, ii. 137.

- climate and scenery, ii. 137.

—, plunts, ii. 137.

, fossils, ii. 138.

$\longrightarrow$ red nud, i. 139.

$\longrightarrow$, progress of, ii. 188.

_., resources, ii. 188.

- Highland settlers, ii. 189.

- timber duties, ii. 190

$\longrightarrow$, appreciation of science, ii. 193

—, "going home," ii. 195.

\section{O.}

Ohin, voters of, i. 186.

$\longrightarrow$, good faith of, i. 186.

_- coul, abundance of, ii. 22.

-

_ Brownsville coal, ii. 22.

$\longrightarrow$, progress of civilisation, ii. 64 .

- population of, ii. 65 .

_ river, succession of steps in banks of, ii. 34 .

Old red sandstone, fish, i. 58 ii. 9,40 .

Onondaga salt group, ii. 217.

Ontario, tortoises, i. 19.

Opossum, fontsteps, i. 133.

Oral instruction, influence of, i. 87.

Ornithichnites, i. 200 .

Outlier of quartzose grit in Alleghanies, ii. 18 .
Owen, Mr. Dale, map of IHinois coal field, ii. 26.

$\longrightarrow$, ii. 207.

Oxford University, peculiaxities of system, i. 215.

$\longrightarrow$, division into colleges, i. 216.

$\longrightarrow$, age of students, j. 217 .

- , choice of teachers, i. 217.

, subversion of original scheme, i 219.

-

- heads of houses, i. 219.

-

—, Sir W. Hamilton on, i. 221.

- establishment of new colleges, $j$ 221.

- Earl of Leicester, i. 222.

- Archbishop Laud, i. 222.

- professors supplanted by college tutors, i. 224.

$\longrightarrow$, laxity of discipline, i. 224.

-

$\ldots$ examination statute of 1800, i. 225 .

, subjects taught by one tutor, i 227

- classification of students, i. 226.

-, responsions, i. 228.

- private tutors or "crammers," i. 229-231.

- talling off of professors' classes, i. 232-237.

- members of convocation, i. 234. , ecclesiastical spirit, i, 234.

$\longrightarrow$, tractarian movement, i. 236.

- , youth of public examiners, i. 238.

- exclusive system, i. 249.

\section{P.}

Packed ice, ii. 144.

Paleoniscus, i. 125 ; ii. 214.

Passports of slaves, i. 134.

Patapsco, valley of the, ii. 5 .

Peacock. Dr., on the statutes of Cambridge university, i. 230.

Peat in Great Dismal, i. 116.

Pecopteris, list of species, ii. 169.

Pelagic deposits, ii. 47.

Penitentiary at Philadelphia, i. 161.

Pennsylvania, anthracite, i. 65, 197.

Pennsylvania, debt of, i. 173.

- defalcation, i. 174

- taxes imposed, i. 175.

-

$\ldots$ tax-assessor's inquiries, i. 176

_-, causes of insolvency, i. 176.

-

- , small power of executive, i. 178.

_ probability of payment, i. 179.

$\longrightarrow$ German population of, i. 182.

- fraudulent voting, i. 184.

Pennsylvanians, conduct of, i. 174.

Pentamerus oblongus, ii. 41, 218.

Percival, Dr, ii. 209.

Percy, Dr., i. $19 \%$.

"Persona! notes," ii. 6 a 
Philadelphia, i. 60, 158.

election, i. 83. 158. reception of Mr. C. Dickens, i.

-, fossil human bones, i. 159.

Dr. Harlan, i. 160.

—, mastodon skeleton, i. 160.

_, penitentiary, i. 161 .

-, financial crisis, i. 172.

Pictou, glacial furrows, ii. 137. , coal field, ii. 163.

Pine Barrens, i. 112, 113.

Pittsburgh, seam of coal at Brownsville, ii. 22.

- vast area of, ii. 25.

___, fossil shells, ii. 28.

Plenters, hospitality of, 107, 123, 121, 139.

$\longrightarrow$, style of living, i. 144.

Plants near Boston, i. 4.

of Schoharie, i. 55.

- near Savannah, i. 134.

Plumbaginous anthracite of Worcester, i. 196 ; preface.

Polished rocks near Lake Erie, ii. 81.

politeness to women, i. 57, 104.

Pomeroy coal, ii. 37 .

Population of the United States, ii. 65.

$\longrightarrow$, Professor Tucker's estimate, ii. 66 .

"Prowth of, in United States, ii. 102.

"Pork aristocracy," at Cincinnati, ii. 61.

Post-pliocene and alluvinm, ii. 213.

Potsdam sandstone, ii. 131.

Pottsville, i. 67.

Prescott's "Conquest of Mexico," i. 91.

Presidential elections, ii. 68.

Producta, hist of species, in Nova Scotia, ii. $18 \%$.

Psuronius, ii. 35.

Q.

Quadrupeds, range of, i. 137.

Quebec, fortifications, ii. 97.

R.

Racoons, i. 133.

Railways, i. 8, 123.

Railway cars, i. 113.

train in N. Carolina, i. 157

Rain-drops at Baltimore, ii. 140.

Ravenel Dr., i. 138.

Recession of Niagara Falls, i. 25, 27.

Redfield, Mr., i. 12, 190.

Red mud of Bay of Fundy, ii. 143.

Religious excitement, i. 162.

Rennsalaer, General Van, i. $56^{\circ}$

Repudiation, i. 171, 188.

, "detector," i. 171.

valueless paper, i. 172 .

Rhode Island, coal plants, i. 196: , democratic movement, ii. 2 .

- charter of Charles II., ii. 2 .
Rhode Island "Suffirage Convention," ii. 4.

Ridges of Alleghanies between Cumberland and Frostburg, ii. 7.

—, monotonous outline, ii. 8.

— between Frostburg and Union, ii.21.

— of sand near T'oronto, ii. 86.

- , uniform level of their base-lines, ii. 88.

- lacustrine theory, ii. 88.

—, Mr. Whittlesey, ii. 91.

—, Mr. Mather, ii. 91.

_ theory of sand-banks, ii. 93.

Ripple-marks, ii. I32.

Rochester sand-ridge, i. 19.

-, mastodon bones, i. 19

"Roches moutonnées," ii. 115.

Rocking-chairs, i. 113.

Rockport, "lake ridges," ii. 71.

Rockville, Waverley sandstone, ii. 40.

Rocky River ridges, ii. 73.

- Hill, trap and sandstone, i. 9.

Rogers, Professor W. B., i. 95 ; ii. 206. H. D., i. 66,71 , ii. 296.

Roots, fossil, resting on coal, ii. 155.

Roy, Mr., ii. 85.

Ruffin, Mr., i. 114.

s.

St. David's ravine, i. 39 ; ii. 79.

St. Etienne, ii. 164.

St. John, lake, limestone of, ii. 203.

St. John's College, Cambridge, i. 239.

St. Lawrence Valley, geological resemblance to Scandinavia, ii. 103, 104.

-, glacial furrows, ii. 113. , drift, ii. 116.

Salamander, i. 128.

Sale of literary works in United States; i. 210.

Salt in Unondaga group, ii. 217 .

- springs or licks, ii. 218.

Sond-banks and bars, ii. 90 .

ridge at Rochester, i. 19.

- ridges, ii. $86,87,88,91,93$.

Sandstone of Lake Superior, ii. 258.

Santee Canal, i. 139.

Savannah river, i. 124.

white limestone, i. 138.

- i. 130.

Savings' bank of New York, i. 173.

Saynisch, Dr., i. 50.

Scandinavia, igne $n$ ins rocks of, ii. 104.

Scenery of United States, south of Lake Erie, i 46.

Schoh:rie, i. 55.

Schools, i. 95.

Scotch emigrants, ii. 98.

- settlers, ii. 70 .

Sects, equality of, i. 96.

Servents, difficuliy of obtaining, i. 59.

Settlers, new, i. 20.

- British, unable to speak English, ii. 95.

Shell-bluff, Geo:gia, i. 124, 126. 
Shells, recent, of Massachusetts, i. 5 . , fossils of New Jersey, i. 64 . of eocene deposits, i. 142.

in Frostburg coal, ii. 15. at Big Bone Lick, ii. $5 \%$.

in Montreal Mountain, height of, ii. 119 .

- at Beauport, near Quebec, ii. 121, 125.

Shockoe Creek marls, i. 106.

Shubenacadie River, ii. 139.

$\longrightarrow$, estuary of the, ii. 192.

Sigillariæ in coal strata, ii. 156, 167, 168.

Sillıman, Professor, ii. 14.

Silurian rocks, thinning out, i. 15.

- of New York, i. 45.

- in the Appalachians, ii, 8.

- , fussils of Scandinavia and Russia, ii. 44 .

- formations, absence of land plants and vertebrate animals, ii. 46 .

limestone, with trap, Montreal, ii. 104.

Skunk at Frostbung, ii. 19.

Slave-labour, i. 104, 125.

Slaves, thoughtlessness of, i. 125, 139.

$\longrightarrow$, passports required for, i. 134.

-

—, treatment of, i. 144.

- , boastfulness of, i. 145.

- vanity, i. 145.

- numerical preponderance, i. 146.

__, marriages, i. 146.

-, animal existence, i. 14\%.

- , social degradation, i. 146.

- , rapid increase of, i. 147.

_ obstacles to emancipation, i. 148.

- Jaws against education, i. 149.

150 .

$\longrightarrow$ monopoly of labour, i. 151.

- natural capacities, i. 153.

Slavery, abolition of, i. $153,155$.

Sleigh-driving, i. 99.

Smith's Ferry, birds' foot-prints, i. 200 .

Smoke, absence of, i. 67.

Snow-storm at Durham, i. 101.

Society in Boston, i. 99.

Soldiers make bad settlers, ii. 98 .

South Brooklyn drift, i. 190.

- Joggins, upright fossil trees near, ii. 154 .

Springfield, i. 9.

Squirrels, ii. 59.

Stage-coach drivers, i. 46.

Staten Island syenite, i. 189.

States, unity of, i. 193.

State Surveys, ii. 201, 208.

Steamboats, ii. 130.

on the Hudson, i. 12,57 .

on the Ohio, ii. 27.

Stigmaria at Blossberg, i. 50.

at Pottsville, i. 69.

in coal of Frostburg, ii. 15.

and marine shells, ii. 15.

with other plants, ii. 15.

in sandstone, ii. 160,168 .
Stigmaria ront of Sigiliaria, ii. 157.

Stony Bluff burrstone, i. 126.

"Stump s)atory," ii. 68 .

"Suffrage convention" of Rhode Island, ii. 3.

Sugar-maple, i. 54

Superior, lake, sandstone of, ii. 201.

Swallows' nest, ji. 130.

Sydenham, Lord, ii. 100.

"Sympathisers," ii. 101.

T.

Taconic range of mountains, i. 195.

Tameness of wild animals, i. 52 .

Taxes, i. 175.

- determination to resist, ii. 7 .

Tax assessor's inquiries, i. 176 .

Taylor, Mr. R. C., i. 94 ; ii. 206.

Thames, ii. 197.

Thanksgiving day, i. 97.

Thousand Isles, limestone of, ii. 203.

Three Rivers, Canada, ii. 98.

Timber, destruction of, in New England, i. 9.

- duties, ii. 199.

- Creek, corals, i. 64.

Toronto, ii. 85.

- ridges of sand and gravel, ii. 85.

$\longrightarrow$ Mr. Rny, ii. 85 .

$\longrightarrow$, progress of the colony, ii. 92.

Tortoises, i. 19, 207.

Towns, rapid growth of, i. 17, 48.

Tracks of annelides, ii. 140.

Traetarian movement at Oxford, i. 236.

Trap, ii. 214, 219.

Travelling, economy of time, i. 84

- , facilities of, i. 122.

$\longrightarrow$, ii. 133.

Tree, petrified, in Halifax Museum, i. 2.

Trees, age of, in American forest. i. 48.

- fossil, upright, in Nova Scotia, ii. 149.

Trenton election, i. 83.

-..- limestone, ii. 42 .

Trilobites of New York silurian rocks, ii. 45.

Trinity College, Cambridge, i. 239.

Troost, Dr., ii. 207.

Truro, ravidity of tides, ii. 207.

Tucker, Professor, on United States population, ii. 66.

Tuomey, Mr., i. 157.

Turkey buzzards, i. 129.

U.

Unin or freshwater mussel, ii. 27.

Union coal seam, ii. 22.

Universal suffiage, i. 181.

- aliens, i. 181.

$\ldots$ Irish voters, i. 182.

_, fraudulent voting, i. 184.

- New England States, i. 186.

Universities of U. S., i. 211 . 
Universities of New England, i. 211. , divinity schools, i. 211.

$\sim$

-, early age of quitting college, $\tilde{i}_{i} .214$. , Harvard College system, i. 214. in Scotland, i. 212.

-, multiplication of, i. 211.

, religious tests, i. 212.

, Irish College, i. 213.

- of England, i, 215. See Oxford and Cambridge.

Utica slate, ii. 218.

V.

Vanuxem, Mr., i. 77 : ii. 208.

Virginia, miocene strata of, i. 106 ; preface.

, coal, ii. 214

Voters, alien, i. 181.

- Irish, i. 182.

\section{IV}

Walrus, fossil skull of, i. 205.
Ware, Mr. Henry, i. 92.

Washington, disadvantages of, i. 102. , national museum, i. 102. , General, i. 103.

- 's plantation, i. 158.

W'aterhouse, Mr., ii. 142.

Waveriey sandstone, ii. 40 .

West Indian emancipation, i. 148, 152 16.7.

Wheeling on the Ohio, ii. 28.

- Indian mound near, ii. 29.

Whewell, Dr.. on the University systcm of Cambridge, i. 241, 245.

White Bluff Creek, i. 130.

Whittlesey, Mr., ii. 91, 93.

Wild animals, i. 53.

Williamsburg univorsity, i. 108.

Wilmington, North Carolina, fossils, 1 . 156.

Winouski, falls of, ii. 128.

Woodward, Mr. S., ii. 165.

Worcester, Massachusetts, mica schist, i. 196.

-, plumbaginous anthracite, i. 196; preface. 
$+$

$\cdot$

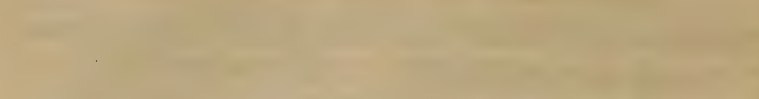
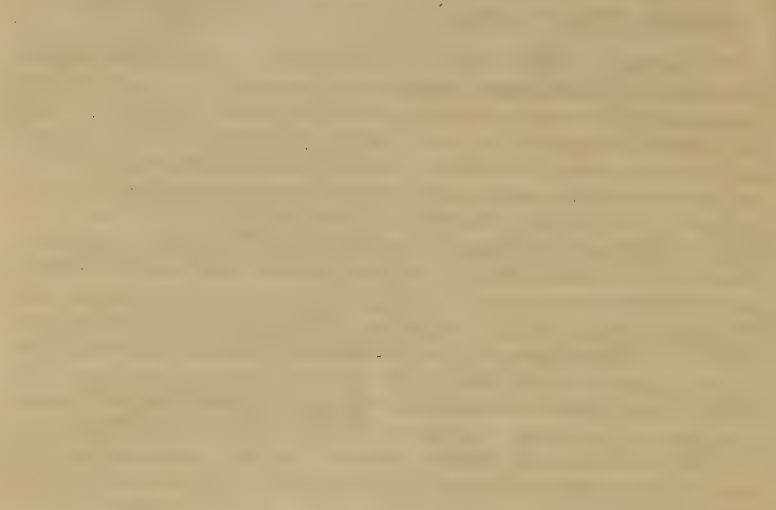

$\cdots$

1

$$
\text { . }
$$

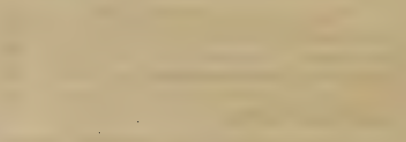

$$
=
$$




\section{VESTIGES OF THE CREATION.}

Vestiges of the Natural History of Creation. By Sir Richard

Vyvyan, Bart., M. P., F. R. S., \&c. One vol. 12mo. well printed. Price 75 cents.

Contents.-1. The bodies of space, their arrangements and formation-2. Constituent materials of the earth and other bodies of space-3. The earth formed; era of the primary rocks-4. Commencement of organic life; sea plants, corals, \&c.-5. Era of the old red sand-stone; terrestrial zoology commences with reptiles; 3 first traces of birds- 5 . Era of the oolite ; commencement of mammalia-6. Era of the cretaceous formations-7. Era of the tertiary formation; mammalia abundant-8. Era of the superficial formations ; commencement of the present spesies-9. General considerations respecting the origin of the animated tribes-10. Particular considerations respecting the origin of the animated tribes-11. Hypothesis of the development of the vegetable and animal kingdom-12. Maclay system of animated nature; this system considered in connexion with the progress of organic creation, and as indicating the natural status of man-13. Early history of mankind-14. Mental constitution of animals-15. Purpose and general condition of the animated creation-16. Note conclusory.

"This is a remarkable volume-small in compass-but embracing a wide range of inquiry, from worlds beyond the visible starry firmament, to the minutest structures of man and animals. The work is written with peculiar and classical terseness, reminding us very mach of the style of Celsus. . . . . We have dedicated a large space to this remarkable work, that may induce many of our readers to peruse the original. The author is, decidedly, a man of great information and reflection."-Medico-Chirurgical Reviev.

"This is a very beautiful and a very interesting book. Its theme is one of the grandest that can occupy human thought-no less than the creation of the universe. It is full of interest and grandeur, and must claim our readers' special notice, as possessing, in an eminent degree, matter for their contemplation, which cannot fail at once to elevate, to gratify, and enrich their minds." -Forbes' Review.

"A neat little volume of much interest. Judging from a brief glance at the contents of the volume, the author has produced a work of great interest, and one which, while it affords the reader useful instruction, cannot fail to turn his mind to a very profitable channel of reflection."-Commer. Adv.

"A small but remarkable work. It is a bold attempt to connect the natural sciences into a history of creation. It contains much to interest and instruct, and the book is ingenious, logical, and learned."-Nevark $\boldsymbol{A} d \boldsymbol{D}$.

"This work discovers great ingenuity and great research into the mysteries of nature. It is a noble work, and one which no intelligent person can read without finding a fresh impulse communicated to his thoughts, and gaining some higher impressions of the Creator's power, wisdom, and goodness." Allany Argus.

"A novel and remarkable work, which will speedily attract the attention of all inquisitive readers. There is much that is new and ingenious in the book. The author, whoever he is, is a man of varied philosophical and literary attainments, and master of a style in conveying his thoughts, so pure, simple, and modest, that his treatise will be everywhere widely read." $-\mathcal{N} . \boldsymbol{Y}_{\text {. }} \boldsymbol{M}_{\mathrm{m}} \mathrm{n}$ ing Neros. 


\section{ACTONIAN PRIZE ESSAY.}

Chemistry, as exemplify:.ng the Wisdom and Beneficence of

God. By George Fownes, Ph. D., F. R. S., Etc. In 1 vol. small 8 vo. Price 50 cents.

Contents.-The Chemical Histor; of the Earth and the Atmosphere; The Peculiar, ies which characterize Organic Substances generally; The Composition and Sustenance of Plants; On Animal Chemistry; The Relation existing between Plant and Animals; Appendix-(with various Tables.)

"The object of the work is to gather up the proofs and indications of design and goodness in the structure and relations of things disclosed by Chemistryand it is very ably done."-N. Y. Post.

"It is richly worth general perusal." $-\mathcal{N}$. $Y$. Tribune.

"The manner of treating the subject is bo:h ingenious and recondite, and we commend it accordingly to general attention." $-\mathcal{N}$. Y. American.

"A highly interesting and valuable work. It is a most valuable addendum to other works on this subject; to those who are studying Natural 'Iheology, it will be highly serviceable." $-\mathcal{N}$. $\boldsymbol{Y}$. Express.

"This is a meritorious work. The materials are fairly and skilfuliy selected out of the vast and ever-growing mass of phenomena and truths which constitute the modern science of Chemistry; and are put together wills considerable dexterity, imparting an air of novelty and freshness even to the truths with which we have been long familiar."-Christian Remembrancer.

\section{HOLY BIBLE, WITH COMMENTARY.}

Now ready-Vols. 1 and $2, \$ 400$ each; or, numbers 1 to 28, of the Holy Bible, with a Critical Commentary and Paraphrase, by Patrick, Lowth, Arnald, Whitby, and Lowman. A new edition, with the text printed at large. To be completed in sixty numbers, at 25 cests each, the whole to form four imperial octavo volumes, containing upwards of 4,300 pages. The value of this edition consists in the fact that the Text accompanies the Commentaries-thus adapting it to general use.

3) Students, Clergymen, and others clibbing together, and remitting the Publishers the amount of five copies, will be entitled to the sixth gratis, or twelve copies for ten, and in the same proportion for a larger number.

** The whole cost of the publication is not required in advance, as the work cail be forwarded in either numbers or volumes, as the party may desire. 


\section{VEGETABLE PHYSIOLOGY.}

The Chemistry of Vegetable and Animal Physiology. By Dr. G. T. Mulder, Professor of Chemistry in the University of Utrecht. Translated from the Dutch, by P. F. H. Fromberg; with an Introduction, by Prof. J. F. W. Johnston. First authorized American Edition; with notes and corrections, by B. Silliman, Jr. Part I., very neatly printed. Price 25 cents.

"In the true study of nature the principal aim ought to be, not only to make ourselves acquainted with the phenomena and laws which distinguish and regulate living and dead matter, but also to arrange those phenomena and laws, and exhibit them in their several relations. The more our knowledge of these two departments is extended, and the nearer the several parts of the great science of nature seem to approximate, the more firmly must we embrace the idea, as necessarily conformable to truth, that the same forces govern alike the ảnimate and inanimate kingdoms."-Author.

"The celebrity of the author of this long-expected work, has raised a high degree of expectation among the readers in this department of scientific literature. For depth of argument and originality of views, he has surpassed all who have gone before him. The work is a profound one, and merits the careful study of all. We look forward with interest to the future numbers of the work."-Tribune.

"For extent and value of research, in the calm spirit of philosophic deduction which marks its peculiar character, and the absence of wild theory-it stands pre-eminent among the numerous profound and brilliant works of a kindred character, which the last two or three years have produced."-Amer. Jour. of Science.

\section{WASHINGTON'S REVOLUTIONARY ORDERS:}

Revolutionary Orders of General Washington, issued during the years 1778, '80, '81, and '82; selected from the Manuscripts of John Whiting, Lieutenant and Adjutant of the 2d Regiment of the Massachusetts Line, and edited by his son, Henry Whiting, Lieut. Col. U. S. Army. 1 vol. 8vo., well printed \$1 50 .

This is a valuable publication-valuable as well from the historic interests of the orders, as from the source whence they emanated. The collection was made from manuscripts that had suffered from inattention, and the series may therefore be incomplete. Yet the papers, now for the first time published to the world, are of an exceedingly interesting character, particularly those dated from the camp at Valley Forge, during a most trying period of the Revolution. To the military man they are invaluable as specimens of clear and concise writing, and for the information they contain touching many questions of dubious interpretation under the code of war. To all they bring before the mind many of the scenes that made the name of Washington immortal, while they contributed to establish the liberty of this great Republic. 


\section{JOHNSTON'S AGRICULTURE.}

Lectures on the Application of Chemistry and Geology to Agriculture. By J. F. W. Johnston. Complete in one thick vol. \$1 25; or in 2 vols. \$1 50 .

\section{Contents:-}

Part 1.-On the Organic Constituents of Plants.

"2.-Or. the Inorganic Constituents of Plants.

" 3.-On the Improvement of the Soil by Mechanical and Chemical means.

“ 4.-On the Products of the Soil and their use in the Feeding of Animais.

Appendix.-Of Suggestions and Results of Experiments in Practical Agriculture.

"It is unquestionably the most important contribution to agricultural science, and destined to exert a most beneficial infuence in this country."-Professor Silliman.

"A work of great value to the agriculturist who wonld avail himself of the aid of science in the cultivation of his land."-Am. Agriculturist.

"This truly valuable work forms the only complete treatise on the whole subject to be found in any language." - Blackwood's Magazine.

"The most complete account of Agricultural Chemistry we possess."-Royal Agricultural Journal.

"We only wish it were in the hands of every farmer's son in the country."Durham Advertiser.

"Nothing hitherto published has at all equalled it, both as regards true science and sound common sense."-Quar. Journal of Agriculture.

"A valuable and interesting Course of Lectures."-London Quar. Revievo.

\section{WATER CURE, FOR LADIES.}

A popular work on the Health, Diet, and Regimen of Females and Children, and prevention and cure of diseases; with a full account of the process of Water Cure, illustrated with various cases, by Mrs. M. L. Shew, revised by Joel Shew, M. D. 1 vol. Price 50 cents.

"A valuable and instructive work on that most interesting branch of modern medical science, the medical virtues of water."- $\mathcal{N}$. $\boldsymbol{Y}$. Express.

"The authoress has reduced the system to practice, and found it every way equal in its curative influences to the representations of its many advocates." True Sun. 


\section{GARDENING FOR LADIES.}

Gardening for Ladies ; and Companion to the Flower-Garden. Being an Alphabetical arrangement of all the ornamental Plants usually grown in gardens and shrubberies; with full directions for their culture. By Mrs. Loudon. First American, from the second London edition. Revised and edited by A. J. Downing. 1 thick vol. 12mo., with engravings representing the processes of grafting, budding, layering, \&c., \&c. \$1 50 .

"A truly charming work, written with simplicity and clearness. It is decidedly the best work on the subject, and we strongly recommend it to all our fair countrywomen, as a work they ought not to be without." $-\mathcal{N}$. $Y$. Courier.

"Mr. Downing is entitled to the thanks of the fair florists of our country for introducing to their acquaintance this coniprehensive and excellent manual, which must become very popular. Besides an instructive treatment on the best modes of culture, transplanting, bedding, training, destroying insects, \&c., and the management of plants in pots and green-houses, illustrated with numerous plates; the work comprises a Dictinnary of the English and Botanic names of the most popular flowers, with directions for their culture. Altogether we should judge it to be the inost valuable work in the department to which it belongs."-Nezoark Advertiser.

"This is a full and complete manual of instruction upon the subject of which it treats. Being intended for those who have little or no previous knowledge of gardening, it presents, in a very precise and detailed manner, all that is necessary to be known upon it, and cannot fail to awaken a more general taste for these healthful and pleasant pursuits among the ladies of our country." $-\mathcal{N}$. $Y$. Tribune.

"This truly delightful work cannot be too highly commended to our fair countrywomen."-N. Y. Y. Journal of Commerce.

"We cordially welcome, and heartily commend to all our fair friends, whether living in town or country, this very excellent work." $-\mathcal{N}$. $Y$. Tribune.

\section{THE BIRDS OF LONG ISLAND.}

Containing a description of the habits, plumage, \&c., of all the species now known to visit that section, comprising the larger number of birds found throughout the State of New York, and the neighboring States. By T. P. Giraud,jr. 1 vol. 8vo. Price $\$ 200$.

This work, though designed chiefly for the use of the gunners and sportsmen residing on Long Island, will still serve as a book of reference for amateurs and others collecting ornithological specimens in various sections of the United Btates, particularly for those persons residing on the sea-coasts of New Jersey and the Easiern States. 


\section{THE NORTH AMERICAN INDIANS.}

Manners and Customs of the North American Indians. In Letters and Notes written during eight years travel annong the wildest tribes of Indians in North America, with 400 spirited illustrations, earefully engraved from his Original Paintings. By George Catlin. A new edition in 2 vols. royal 8vo. Price \$6 00 , bound in cloth.

* * Four editions of this very interesting work have been printed in London. Among the subscribers were the Queen, the Queen Dowager, the King of Belgium, and many of the most distinguished persons in Europe. It contains characteristic and faithful records of a race of people who are rapidly becoming extinct: and it is not probable that another similar work can ever be written. One of the most remarkable tribes, the Mandans, are already entirely destroyed. This work has been more extensively, copiously, and favorably reviewed in Europe, than any other published during the last five years.

\section{BULL'S HINTS TO MOTHERS.}

Hints to Mothers, for the Management of Health during the period of pregnancy, and in the lying-in room; with an exposure of popular errors in connection with those subjects. By Thomas Bull, M. D. 1 neat vol. Fourth Edition. Price 38 cents; or in cloth binding, 50 cents.

"We recommend it to our readers; and they will confer a benefit on their new married patients by recommending it to them." - Forbes' Review.

"There is no mother that will not be heartily thankful that this book ever fell into her hands; and no husband who should not present it to his w'ite. We canuot urge its value too strongly on all whom it concerns."-Med. Times.

\section{FLORA OF NORTH AMERICA.}

Flora of North America, comprising an account of all the indigenous and naturalized plants growing north of Mexico. By John Torrey and Asa Gray. Vol. 1, (pp. 771,) price $\$ 600$. Vol. 2, parts 1, 2, 3. \$4 00 .

This is the only authentic and complete American Flora. The object of the work is to give a scientific account of all the indigenous and naturalized plants of North America at present known. It is the most extensive local Flora that has ever been undertaken. The latest Flora of this country, that of Pursh, was published twenty-eight years ago, at which period extensive regions, even within the United States proper, had never been visited by the Botanist. Since that time, the number of known plants has vastly increased; and the science itself has made such rapid advancement, that this work will present the Botiny of this country in an entirely new aspect. 


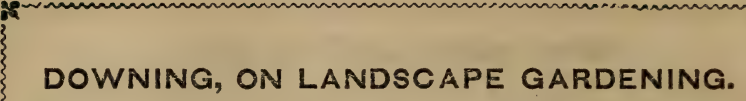

A Treatise on Landscape Gardening; adapted to North America, with a view to the improvement of Country Residences. Comprising historical notices, and general principles of the art; directions for laying out grounds, and arranging plantations; description and cultivation of hardy trees; decorative accompaniments to the house and grounds ; formation of pieces of artificial water, flower-gardens, etc. ; with remarks on Rural Architecture. New edition, with large additions and improvements, and many new and beautiful illustrations. By A. J. Downing. 1 large vol. 8 vo. \$3 50 .

"This volume, the furst American treatise on this subject, will at once take the rank of the standard work."-Silliman's Journal.

"Downing's Landscape Gardening is a masterly work of its kind,-more especially considering that the art is yet in its infancy in America."-Loudon's Gardener's Magazine.

"Nothing has been omitted that can in the least contribute to a full and analytical development of the subject; and he treats of all in the most lucid order, and with much perspicuity and grace of diction."-Democratic Reviewo.

"We dismiss this work with much respect for the taste and judgment of the author, and with full confiderice that it will exert a commanding influence. They are valuable and instructive, and every man of taste, though he may not need, will do well to possess it."-North American Review.

\section{DOWNING'S FRUITS OF AMERICA.}

The rruits and Fruit Trees of America ; or, the culture, propagation, and management, in the garden and orchard, of fruit trees generally; with descriptions of all the finest varieties of fruit, native or foreign, cultivated in the gardens of this country. Illustrated with numerous engravings and ovtlines of fruit. By A. J. Downing. 1 vol. 12mo., (and also 8 vo.

* * 'I'his will be the most complete work on the subject ever published, and will, it is hoped, supfly a desideratum long felt by amateurs and cultivators. 
E.̄then; or, Traces of Travel brought Home from the East. 1 neat volume, very handsomely printed on fine paper. 50 cents.

Contents-Preface-Over the border-Journey from Belgrade to Constantinople-Constantinople-The Troad-Infidel Smyrna -Greek mariners-Cyprus--Lady Hester Stanhope--The Sanctuary-The monks of the Holy Land-From Nazareth to Tiberias - My first bivouac-The Dead Sea-The black tents-Passage of the Jordan-Terra Sancta-The desert-Cairo and the plague -The Pyramids- The Sphynx-Cairo to Suez-Suez-Suez to Gaza-Gaza to Nablous-Mariam-The prophet Damoor-Damascus-Pass of the Lebanen-Surprise of Satalieh.

"Graphic in delineation, animated in style, frank in manner, and artistical in the choice and treatment of the subjects selected for presentation." - Spectator.

"He has wit and humor that shed an illustrative glean on every olject which he describes, placing it in the happiest relief."-Athenceum, (first notice.)

"The book is as 'light as light,' and as lively as life, yet are there in it passages and scenes which would make most men grave and solemn."-Atlıenaum, (second notice.)

"This book with a bad title is wonderfully clever."-Examiner.

"We have seldom, in a word, perused a volume which so irresistibly claims the attention, from the first page of the preface to the finale of the wanderings."-Atlas.

"If these be not poetry, and of a pure and striking kind too, we are no critics."-Literary Gazette.

"It is novel in all its details."-Britannia.

"His account is brief, but were volumes written it could not bring the actual scene more to our mind's eye. We are frequently startled in the midst of mirth by some great touch of nature-some terrible display of truth."-News of the World.

"The scenes through which he passed are exhibited with a clearness, and stamped upon the mind with a strength, which is absolutely fascinating. The whole is accompanied with the strong commanding evidence of truth, and embellished with all the beauty of poetry."-Globe.

"This is the sort of writing for a traveller-sketchy, vigorous, and origlnal." -Morning Post.

"A book which exerts a very fascinating effect on its readers."-Morning Chronicle.

"We have rarely met with a work of the kind, blending so successively curious and instructive information with light and amusing reading." - Westninster Reviero.

"Nothing so sparkling, so graphic, so truthful in sentiment, so poetic in vein, has issued from the press for many a day."-The Critic.

"This is a real book-not a sham. It displays a varied and comprehersve power of mind, and a genuine mastery over the first and strongest of modern languages. The author has canght the character and humor of the eastern mind as completely as Anastasius, while in his gorgeous descriptions and powe: of sarcasm he rivals Vathek. His terseness, vigor, and bold imagery remind us of the brave old style of Fuller and of South, to which he adds a spirit, freshness, and delicacy all his own."-Quarterly Reviewo. 


\section{DR. CHEEVER'S LECTURES ON BUNYAN.}

Lectures on the Pilgrim's Progress, and on the Life and Times of John Bunyan. By the Rev. George B. Cheever, D. D. 1 thick rol. 8vo., printed in large type, with fine steel-plate engravings. $\$ 350$; or in 15 numbers at 25 cents each.

Contents.-1. Bunyan and his Times; 2. Bunyan's Temptations; 3. Bunyan's Examination ; 4. Bunyan in Prison; 5. Providence, Grace, and Genius of Bunyan; 6. City of Destruction and Slough of Despond; 7 . Christian in the house of the Interpreter; 8. Christian on the Hill of Difficulty; 9. Christian's fight with Apollyon; 10. Christian in the Valley of the Shadow of Death; 11. Christian and Faithful in Vanity Fair; 12. Doubting Castle and Giant Despair; 13. The Delectable Mountains and Enchanted Ground; 14. Land Beulah and the River of Death; 15 . Christiana, Mercy, and the Children.

"We know of nothing in American literature more likely to be interesting and useful than these lectures. The beauty and force of their imagery, the poetic brilliancy of their descriptions, the correctness of their sentiments, and the excellent spirit whici pervades them, must make their perusal a feast to al of the religious community."-Tribune.

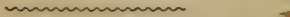

\section{DOWNING'S COTTAGE RESIDENCES.}

Designs for Cottage Residences, adapted to North America, including Elevations and Plans of the Buildings, and Designs for Laying out Grounds. By A. J. Downing, Esq. 1 vol. 8vo. with very neat illustrations. Second edition, revised. $\$ 200$.

A second edition of the "Cottage Residences" is just published, as Part I. ; and it is announced by the Author that Part II., which is in preparation, will entain bints and designs for the interiors and furniture of cottages, as well as additional designs for farm buildings.

One of the leading reviews remarked that "the publication of these works may be cossidered an era in the literature of this country." It is certainly true that no works were ever issued from the American press which at once exerted a more distinct and extended influence on any subject than have these upon the taste of our country. Since the publication of the first edition of the "Landscape Gardening," the taste for rural embeilishments has increased to a surprising cxtent, and in almost every instance this volume is the text-bonk of the inprover, and the exponent of the more refined style of arrangement and keeping introduced into our country residences.

The "Cottage Residences" seems to have been equally well-timed and happily done. Country gentlemen, no longer limited to the meager designs of uneducated carpenters, are erenting agreeable cottages in a variety of styles suited to the location or scenery. Even in the West and South there are already many striking cottages and villas built wholly, or in part, from Mr. Downing's designs : and in the suburbs of some of the cities, most of the new residencrs are modified or moulded after the hints thrown out in this work. 
8:

Ft megso sentr

6

3

$\because x^{4} \times x^{3}=$

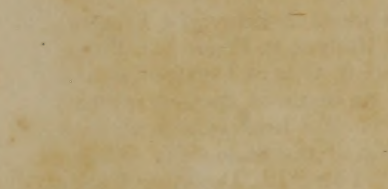

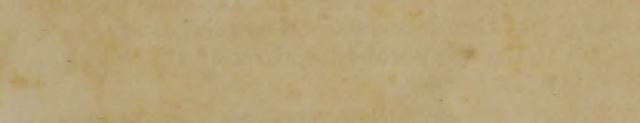

$3+\frac{1}{2}$

$+4$

$2 x$

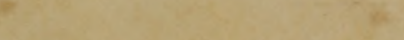

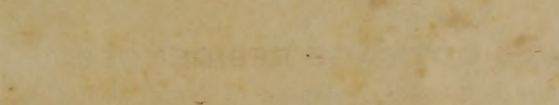

(1)

2.

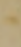

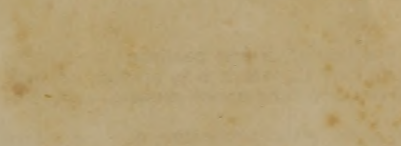

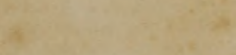

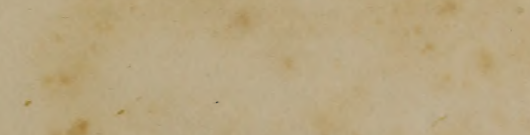

$+$

xa:

(3)

개감

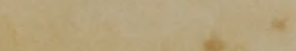

\%

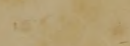

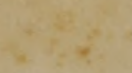

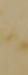

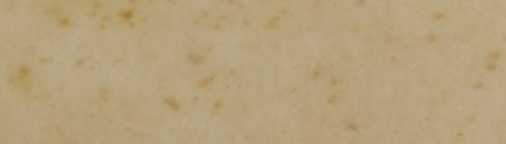






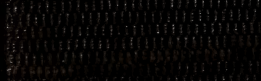

Fi:

28

$$
y^{4} y^{i t}
$$

